\title{
UPPER SALINAS HEADWATERS CONSERVATION PLAN
}

\author{
A Professional Project \\ Presented to \\ the Faculty of California Polytechnic State University, \\ San Luis Obispo
}

\author{
In Partial Fulfillment \\ of the Requirements for the Degree \\ Master of City and Regional Planning
}

By

Justin T. Saydell

October 2011 
(C) 2011

Justin T. Saydell

ALL RIGHTS RESERVED

Cover photo courtesy of B.K. Richard 


\section{COMMITTEE MEMBERSHIP}

Title: Upper Salinas Headwaters Conservation Plan

Author: Justin T. Saydell

Prepared for the Land Conservancy of San Luis Obispo County

Date Submitted: September X, 2011

COMMITTEE CHAIR:

Chris Clark, Lecturer, Cal Poly

COMMITTEE MEMBER:

Adrienne Greve, Associate Professor, Cal Poly

COMMITTEE MEMBER:

Robert Hill, Executive Director, Land Conservancy of San Luis Obispo County 


\title{
Upper Salinas Headwaters Conservation Plan
}

Executive Summary

\author{
By Justin T. Saydell
}

The Upper Salinas Headwaters Conservation Plan is an effort to understand the cultural and ecosystem resources in the region, develop tools for conservation planning, and suggest a strategy and plan of action for implementation of those strategies. The plan covers a 218 square mile area between the Santa Lucia and the La Panza mountain ranges, south of Atascadero and east of the City of San Luis Obispo. The Conservation Area consists of rugged terrain made up of vast-relatively untouched open space. The area consists of several different vegetative communities including oak savannah grasslands, mixed hardwood and oak stands, shrubland, wetland and riparian corridors. The region is host to a number of land uses predominantly agriculture (mainly cattle ranching), some urban development, outdoor recreation, and a few mining operations.

Approximately fifty-five percent of the acreage within the Conservation Area is designated public land (federal, state, and county), while the remaining acreages are dominantly private lands with Rural or Agriculture designations. Places of interest within the Conservation Area include the Upper Salinas River, Santa Margarita Reservoir, the historic Santa Margarita Ranch, and the town of Pozo.

The region that contains the Conservation Area has been identified as having significant ecological resources (migratory corridors, important/rare vegetation communities, and a system of tributaries critical to Salinas River water quality and supply downstream.) The recognition of this important area has come from the California Rangeland Conservation Coalition statewide landscape priorities, The Nature Conservancy, the South Coast Wildlands Program, and a countywide report completed for The Conservancy by Catherine Lambert in 2007, which utilized Geographic information Systems (GIS) to assess ecosystem attributes and growth pressure parameters. The region containing the Conservation Area received a moderate to high combined score as a result of the assessment, suggesting a need for conservation efforts and resources from the Conservancy.

The Conservation Area is based roughly on the shape of the subwatersheds that make up part of the larger Upper Salinas watershed. Several headwater tributaries flow into the Salinas River; a river utilized by several municipalities and agricultural operations as it flows north to Monterey Bay. Land use changes in the region can negatively affect water quality and supply downstream as well as degrade important habitat for fish and wildlife. Projected urban develop pressures from the City of Atascadero and an increase in more intensive agricultural production places increasing pressure on both local ranching operations and the regional ecosystem. The large amount of contiguous public land presents an opportunity for a conservation strategy aimed at creating expansive public-private protected lands that will ensure long-term protection of agricultural, hydrological, and wildlife resources. 
This conservation plan was developed primarily using GIS information from The Conservancy and data used with permission from the County of San Luis Obispo. GIS maps were created and utilized along with aerial photos from Google Earth to analyze the landscape for the following:

- vegetation communities

- stream flow direction and order

- types of development

- land ownership/parcel data

- agricultural soils
- geology

- existing protected areas

- conservation potential

- potential project sites for restoration/enhancement

The GIS maps, aerial photo analysis, and information collected from interviews with several family ranchers are intended to be used as decision-support tools for future conservation projects in the region. However, for this plan, strategic and implementation recommendations are suggested in the form of long-term conservation agreements, land use management and restoration/enhancement techniques based on analysis of the information that was collected.

The conservation strategy of this plan emphasizes the utilization of existing protected landscapes, primarily public land, along with the establishment of partnerships with private landowners within the Conservation Area to develop large contiguous tracts of protected land in the headwaters region of the Salinas River. The ranching heritage in the region, diversity of habitat and wildlife, sensitivity of hydrological resources, moderate to high levels of development potential from urban development, and more intensive agricultural production makes the Conservation Area in the Upper Salinas Watershed an essential target for conservation efforts. 


\section{ACKNOWLEDGEMENTS}

I'd like to give a sincere thank you to my committee members, Chris Clark, Adrienne Greve, and Bob Hill who lent me their expertise, wisdom, support, and friendship throughout the process. I very much appreciate everything they have done to help me along the way. I would also like to thank the ranchers who took time out of their busy schedules to share their stories and provide some insight into the goals and challenges of running a family ranching operation. A special thank you goes out to my dedicated friends Ari and Kyle for voluntarily undertaking the tumultuous task of editing this document. Most importantly, l'd like to thank my friends and family near and far for their unwavering support, understanding, and compassion throughout this process. They were there through the thick and thin and provided the external motivation and friendship I needed to complete this project. 


\section{Table of Contents}

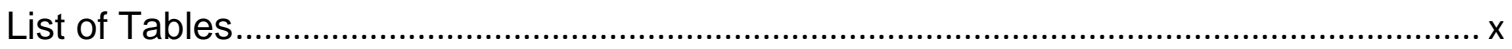

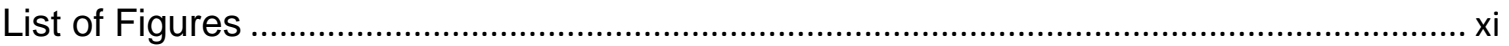

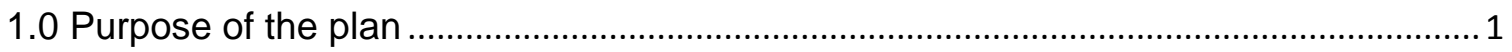

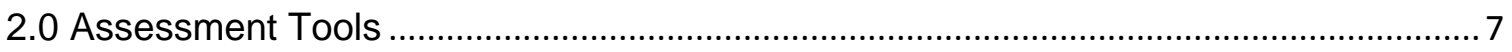

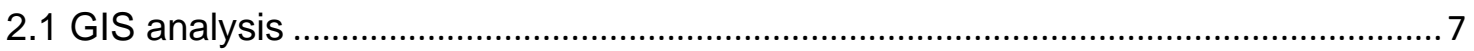

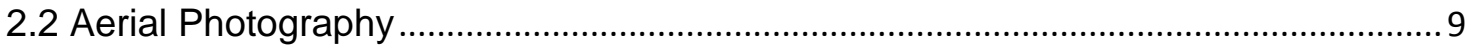

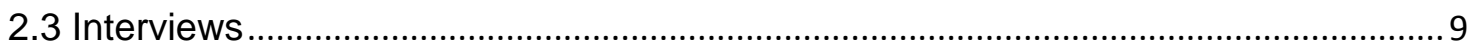

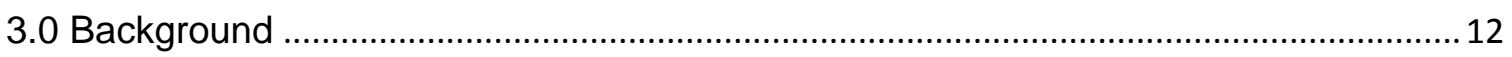

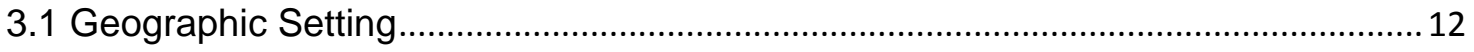

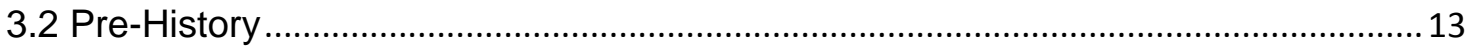

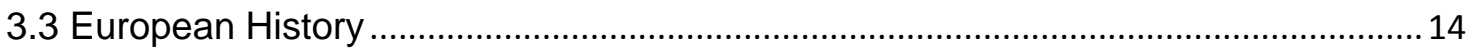

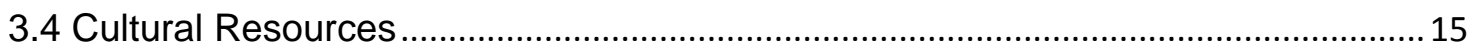

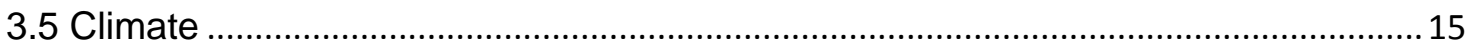

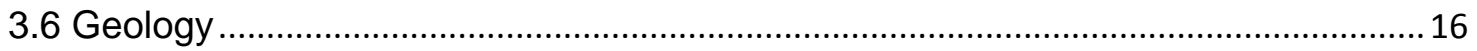

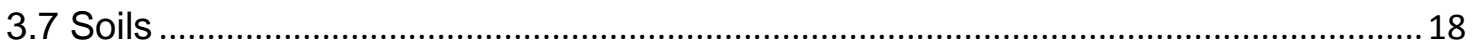

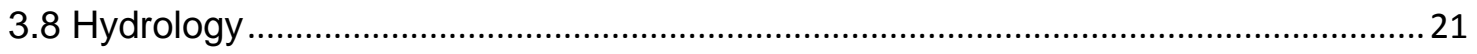

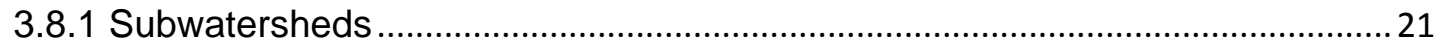

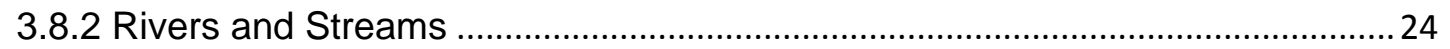

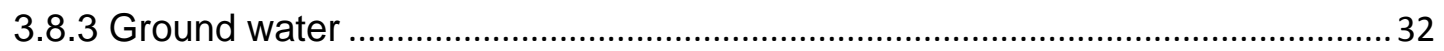

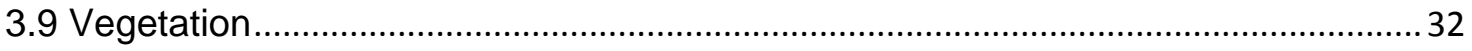

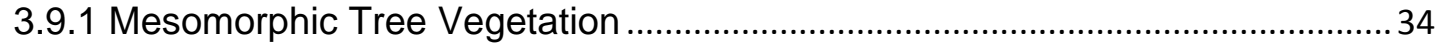

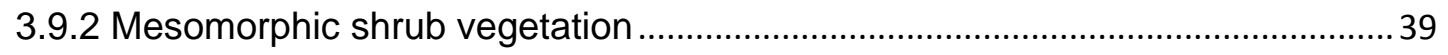

3.9.3 Mesomorphic Herbaceous Vegetation............................................................. 42

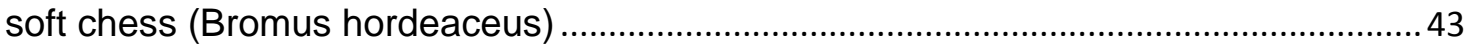

3.9.4 Temperate Flooded Riparian Vegetation........................................................... 44

3.9.5 Temperate Meadow and Vegetated Wetland/Marsh Areas................................ 47

3.9.6 Wetlands Associated with Naturally Sparse or Un-vegetated Areas ................ 48

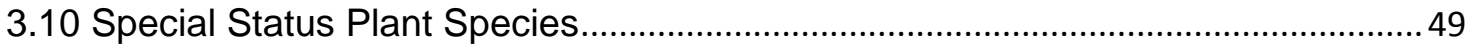

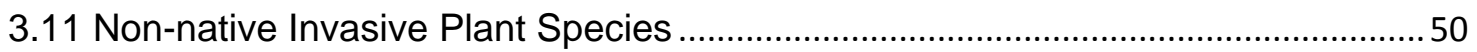




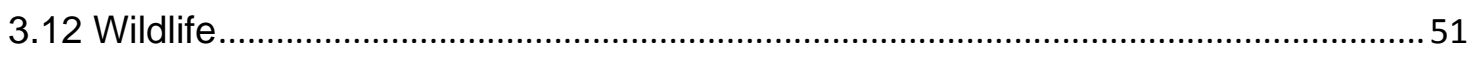

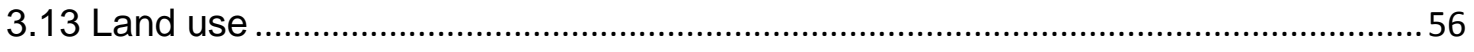

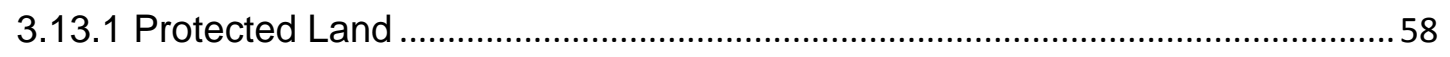

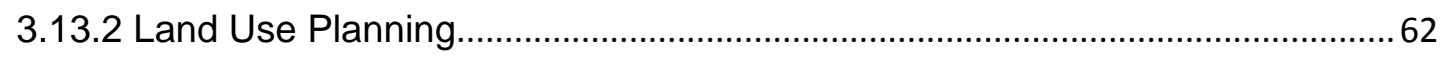

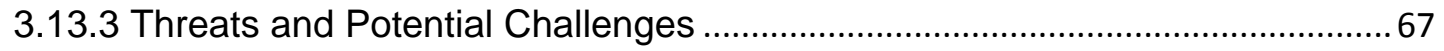

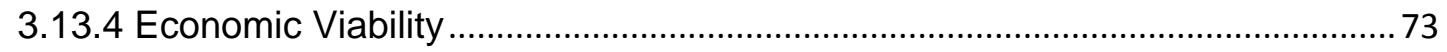

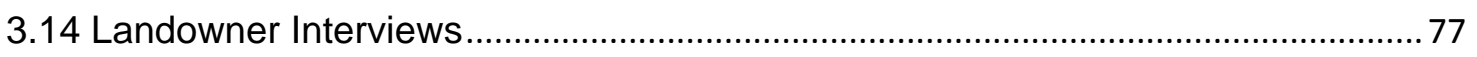

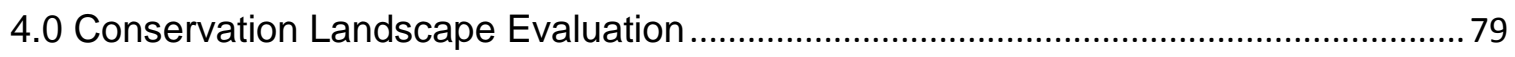

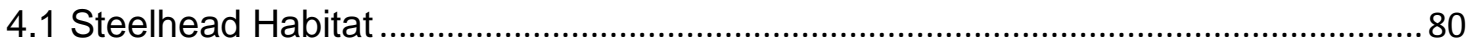

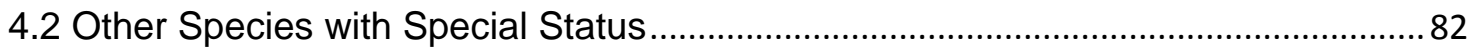

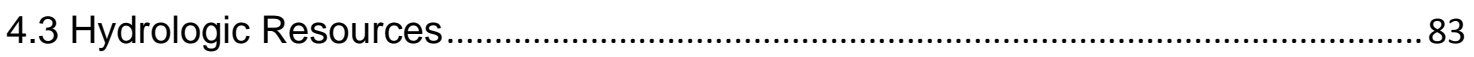

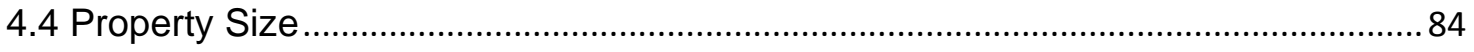

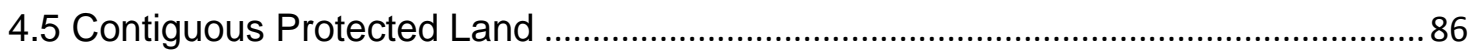

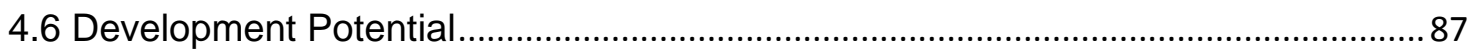

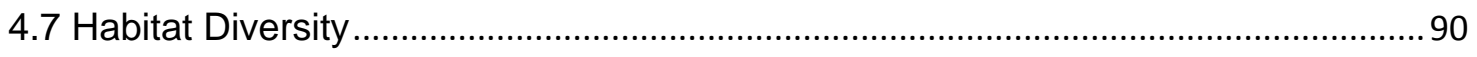

4.8 Oak Woodland/Hardwood Diversity ...................................................................... 92

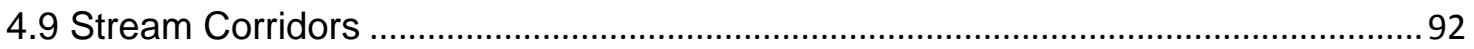

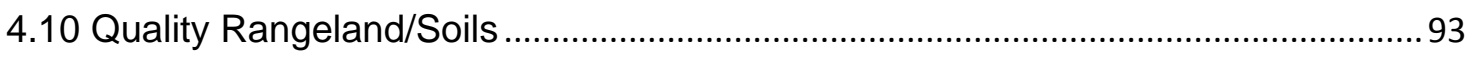

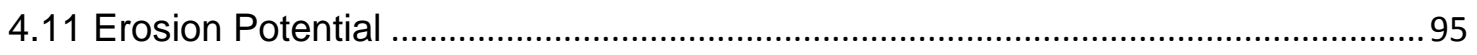

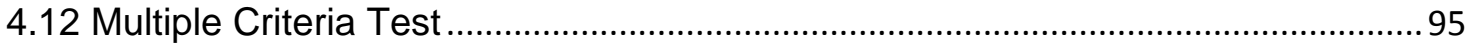

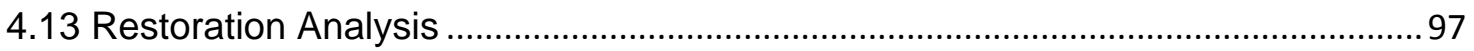

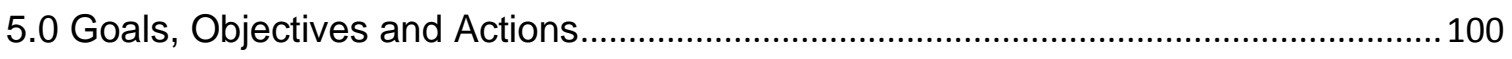

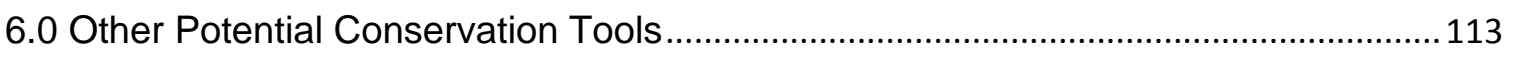

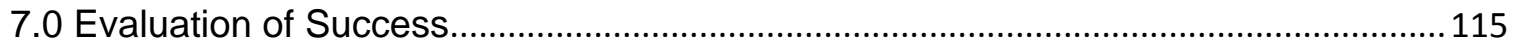

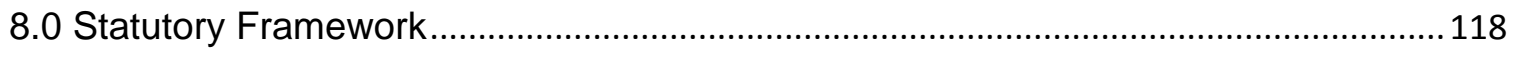

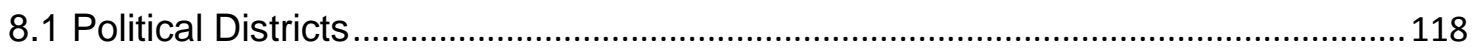

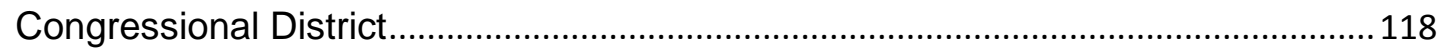

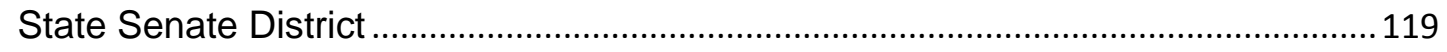

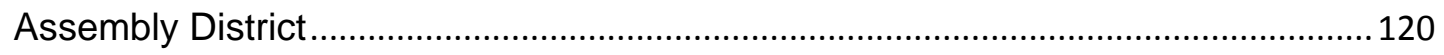

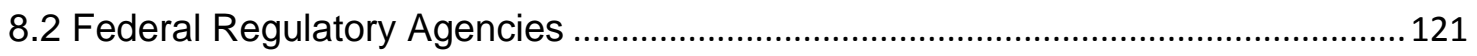

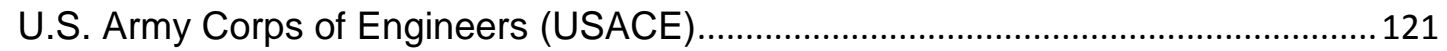

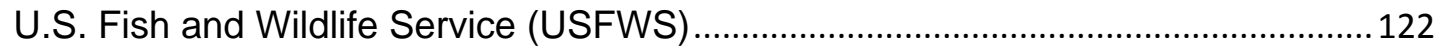


National Oceanic and Atmospheric Administration (NOAA) Fisheries Service ....... 122

U.S. Environmental Protection Agency (USEPA) …................................................. 123

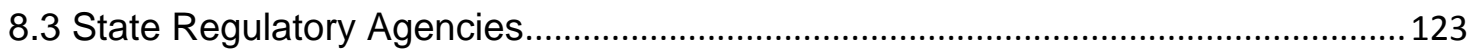

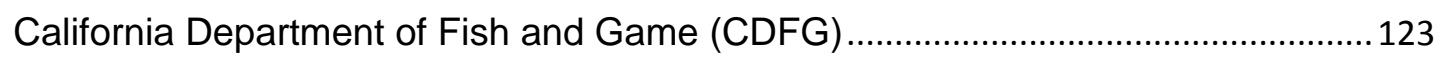

Regional Water Quality Control Board (Regional Boards) ........................................ 124

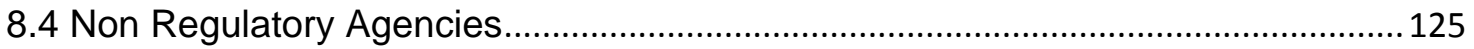

Natural Resources Conservation Service (NRCS) ….............................................. 125

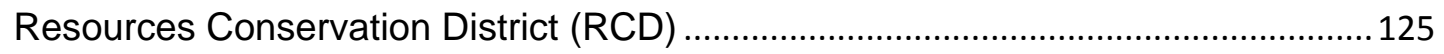

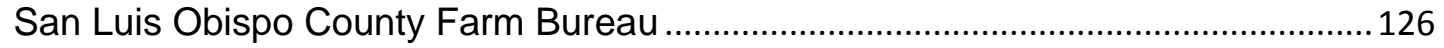

Central Coast Salmon Enhancement (CCSE) ......................................................... 127

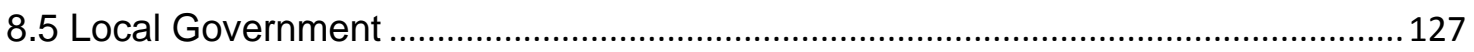

County of San Luis Obispo Planning and Building ................................................... 127

San Luis Obispo County Fire Department/Cal Fire .................................................128

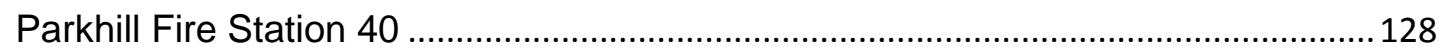

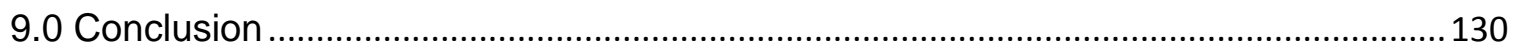

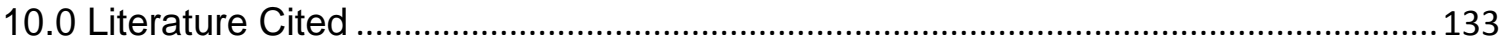

APPENDICES

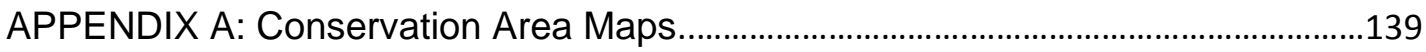

APPENDIX B: Plant Species in the Conservation Area..................................................156

APPENDIX C: Wildlife Species in the Conservation Area..............................................164

APPENDIX D: Williamson Act and Property Taxes..........................................................169

APPENDIX E: Santa Margarita Ranch Proposed Development..................................170

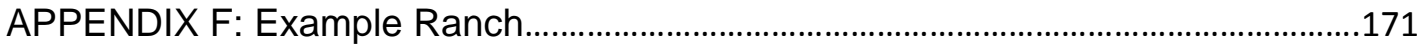

APPENDIX G: Rancher Conservation Values.............................................................173

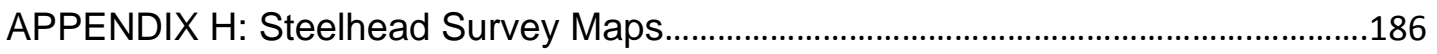

APPENDIX I: Goals, Objectives, Actions, and Descriptions........................................188

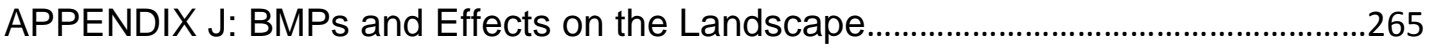

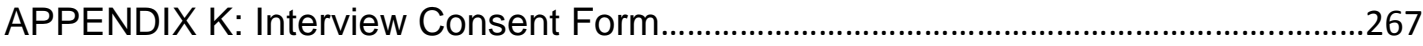

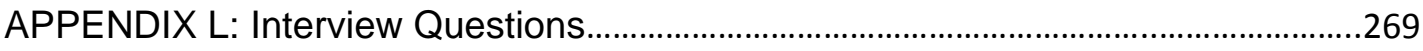




\section{List of Tables}

Table Page

3.1 NRCS Farmland Soil Classification............................................................................21

3.2 Upper Salinas Subwatersheds within the Conservation Area...................................23

3.3 Streams and stream orders.....................................................................................28

3.4 Vegetation Types......................................................................................................34

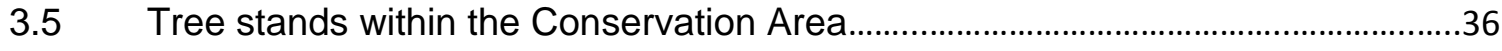

3.6 Common native herbaceous chaparral species.......................................................40

3.7 Common Central (Lucian) Coast Scrub Species.......................................................41

3.8 Common perennial grassland species....................................................................43

3.9 Common annual grassland species.........................................................................43

3.10 Common riparian species in the Conservation Area...............................................47

3.11 Common wildlife species found in Scrubland habitat in the region.........................55

3.12 Common grassland species found in the region.......................................................56

3.13 Land use designations within the Conservation Area................................................58

3.14 County of San Luis Obispo Building Intensity per Land

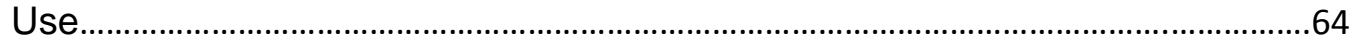

3.15 Summary of the proposed Agricultural Cluster and Future Development Program at Santa Margarita Ranch................................70

4.1 Large property owners within the Conservation

Area

9.1 Examples of some potential permit requirements and the responsible/permitting agencies. 


\section{List of Figures}

Figure

Page

$1.1 \quad$ Conservation Area boundary ....................................................................................

3.1 Conservation Area location......................................................................................13

3.2 South Coast Wildlands Essential Habitat Connectivity Priorities................................52

4.1 An aerial photograph of dryland row crop agriculture and vineyards near the Salinas River within the Conservation

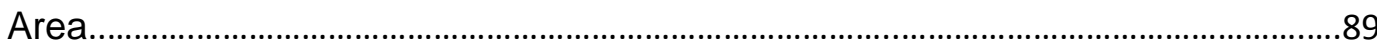

4.2 Aerial photograph of a mining operation along the Salinas River...........................90 


\subsection{Purpose of the plan}

The headwaters region of the Salinas River in central western San Luis Obispo County is a beautiful oak savannah and chaparral countryside once considered a typical California landscape. Surrounded by two coastal mountain ranges and bordered by a National Forest, the Upper Salinas headwater region is a pristine natural landscape, supporting a diverse array of flora and fauna, while simultaneously being utilized as a working landscape for agriculture, primarily ranching, but also include hay production and viticulture.

The conservation plan creates a vision through the development of conservation strategies for the protection of private land and helps the Conservancy make informed decisions regarding the protection of rangeland and preserve an agricultural heritage that has been a part of the region for hundreds of years. In this plan, the area is known as the Conservation Area and is outlined in Figure 1.1. The plan is a culmination of background research, GIS and aerial photography analysis, as well as interviews with landowners within the Conservation Area. This information is meant to aid the decisionmaking process in order to set priorities for land conservation projects in a way that is transparent, understandable and in line with the mission of the Land Conservancy of San Luis Obispo County. 
Figure 1.1 Conservation Area boundary

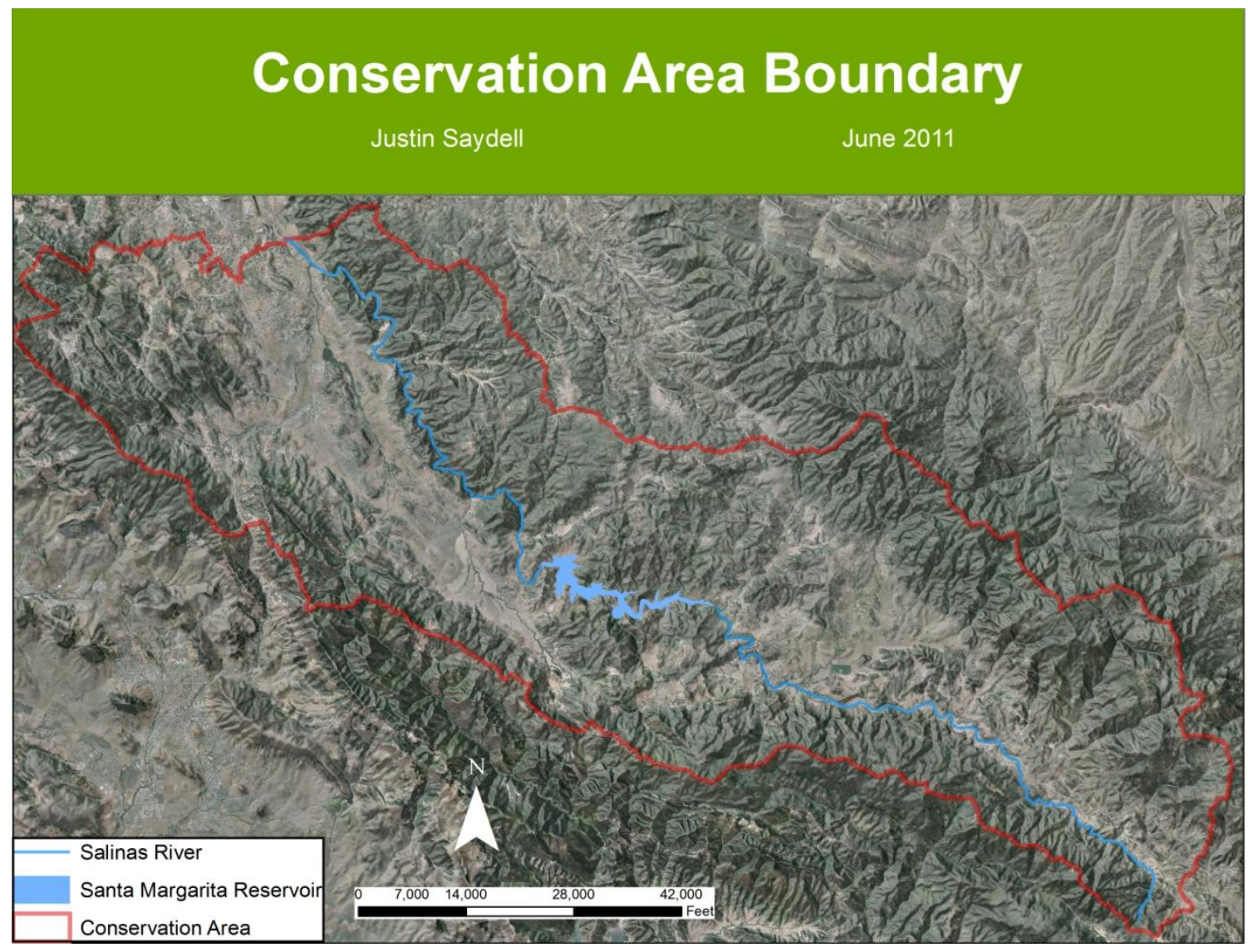

Future changes in land use can result in devastating effects on unique plant communities, wildlife habitat, and to watershed functions throughout the drainage system (Freeman et al. 2007 and Barrios 2000). Preserving rangeland and other open spaces in the region can stave off increased land use intensity and enable ranching and farming to continue within the Conservation Area. Conservation tools, such as conservation easements, are proving to be important mechanisms that can aid in the protection of important landscapes to ensure landowners can keep working their land and important ecosystem attributes are protected at the same time.

The plan focuses on an area of the headwater region surrounding Santa Margarita Lake near the City of San Luis Obispo to the west and the City of Atascadero to the immediate north. The project area is located within the Upper Salinas Watershed 
and is surrounded by the Los Padres National Forest. This plan provides a framework for the following:

- Maintaining and improving water quality within the Upper Salinas Watershed including the Salinas River and its tributaries at levels sufficient to provide healthy drinking water and support natural resources.

- Protecting and restoring the natural function of streams and associated riparian zones, giving priority to tributaries that support steelhead, particularly below Santa Margarita Reservoir.

- Protecting and restoring wildlife corridors to maintain connectivity between important habitats including oak and other hardwood stands, grassland, scrub/shrub vegetation communities, riparian corridors, and areas that host wetlands and vernal pools.

The plan recognizes that landowners, particularly ranchers, are essential to the success of regional conservation efforts. Privately owned rangeland supports a number of wildlife species and their habitat. The large contiguous tracts of land provide important wildlife corridors and are essential to the maintenance of the quality and quantity of water in the region. They are also important because their management decisions and plans for the future of their land reflect continued landscape viability, stewardship and long-term protection of critical natural resources. This plan utilizes conservation easements as the primary long-term conservation tool, land use management Best Management Practices and restoration recommendations.

Information gathered from local landowner input, technical reports and GIS analysis was utilized to develop strategies to protect and improve important resources within the Conservation Area. The plan also addresses watershed health as it pertains to water quality. A clean water supply from the Salinas River headwaters is important to 
municipal and agricultural water users downstream. Changing land use intensities can have negative effects on downstream water quality and supply. Protecting water supply is also important in California with the advent of a changing climate and shortages of quality water supplies (Smoot et al. 2004; Allan 2004; Crim 2007). There are several important water users that utilize the Salinas River watershed and/or underlying ground water supplies including the City of San Luis Obispo, Santa Margarita, Atascadero and Paso Robles. Understanding the threats and opportunities to protect the watershed would be of interest to water users downstream.

Several organizations have identified the Salinas headwaters region as an important natural resource and agricultural area under an increasing degree of threat from urban cores to the northwest and from a shift to higher intensity agricultural practices. A report completed by Crawford, Multari, Clark, and Mohr (2000) for the Nature Conservancy and the Land Conservancy of San Luis Obispo County, identified the landscape within the Conservation Area as having significant natural resource value, oak hardwood stands, riparian habitat, and wildlife corridors. Private land in the area plays a significant role in providing connectivity between two mountain ranges that span the California Coast. The Focus Area Prioritization Map by the California Rangeland Conservation Coalition identifies the Conservation Area as important and/or critical to their conservation goals. Some areas are recognized as being under threat of fragmentation from development (California Rangeland Conservation Coalition 2007). The California Department of Forestry and Fire Protection (2010) forestry and rangeland assessment labels much of San Luis Obispo County, including lands within the Conservation Area as being a High Priority Landscape (HPL) for the area's quality habitat, watershed conditions, importance to downstream water users, and open space/ rangeland significance. The analysis highlights areas where stewardship projects have the highest potential to protect and enhance water quality. In another report completed 
by Catherine Lambert (2007) as a Master's project in City and Regional Planning at California Polytechnic State University, weighted conservation prioritization in the county identified the Conservation Area as having a moderate to high ranking in natural resource value and growth pressure.

This plan, in parallel with the Land Conservancy of San Luis Obispo County's mission and the strategic plan of the Las Tablas Resource Conservation District, serves several functions including:

- Identifies important natural and hydrological resources within the Conservation Area.

- Determines beneficial land uses such as low impact agriculture that the Conservancy views as an important working landscape resource.

- Evaluates potential landscape challenges and threats including the increased intensity land uses such as rural and urban development and certain types of agriculture such as vineyards.

- Locates areas that should be pursued by the Conservancy both for long-term conservation and potential restoration efforts.

- Strategizes ways in which the Conservancy can work towards protecting private land while benefiting landowners.

Insight from this plan will allow the Conservancy to weigh land use threats and prioritize conservation efforts within the Conservation Area based on the information gathered from the landowners that were interviewed, GIS information obtained from the County of San Luis Obispo, literature review and analysis.

The Upper Salinas Headwaters Conservation Plan is organized into nine chapters starting with assessment methodology. This was done because much of the 
conservation plan background is an assessment/description of existing conditions. Background information is utilized to provide an understanding of the landscape including important natural resource and ecosystem attributes as well as the working landscape and policy framework for the area. Subsequent chapters incorporate this background information to provide a landscape evaluation based on select criteria for prioritizing conservation projects, establishment of goals and objectives in order to best protect the landscape. Actions items and evaluation of their effectiveness are also included. This document also includes a list of the agencies and organizations and the roles they play in land use regulations and decision-making. Appendices are included in this document following the plan and include more detailed information, maps, illustrations and other informational material and are referenced in the plan. Appendix A includes Figure A.13, which is a map of identified large properties within the Conservation Area. Landscape characteristics on these properties are discussed throughout the plan and readers should refer to Figure A.13 in Appendix A to identify where the numbered properties being discussed are located within the Conservation Area. 


\subsection{Assessment Tools}

The Salinas Headwaters Conservation Plan employs several assessment tools that were utilized in order to make inferences about where conservation efforts should be focused. Analysis of the Conservation Area was conducted to evaluate and propose potential long-term conservation and enhancement (restoration) projects. Properties identified as having significant ecosystem characteristics such as oak stands, perennial streams, adjacent protected areas, and diverse habitat structures are considered to have important conservation characteristics. Several methods were employed to collect, analyze and interpret data specific to the Conservation Area. The following methods are described below and include:

- Analysis of GIS data and maps

- Analysis of aerial photography

- Interviews with landowners

The tools utilized to assess conservation priorities in this plan are to inform the Conservancy on the potential for projects within the Conservation Area. They also provide a support mechanism for conservation decision-making. This plan ensures a degree of flexibility in what projects are targeted by presenting ecosystem and land use features without using a stringent approach to prioritization. This allows the Conservancy to justify projects based on specific and potentially conditional conservation needs and opportunities on specific properties with unique ecosystem and working landscape qualities.

\subsection{GIS analysis}

Geographic Information Systems are an important tool for conservation. The user can create spatial representations of available information highlighting particular 
features and their relationships to each other. For this plan, spatial representations of particular physical features aid in the analysis of the relationships between landscape characteristics in order to make decisions about where and how conservation priorities and resources should be allocated in order to protect and/or enhance important areas within the Conservation Area. Data from the County of San Luis Obispo and the Conservancy of San Luis Obispo County were utilized to create GIS maps. These maps were utilized in the analysis of landscape characteristics. The characteristics analyzed in this plan using GIS include:

- Parcel size

- Relationship to existing protected landscapes

- Water resources

- Vegetation communities

- Oak Stands

- Prime agricultural soils and areas currently used for agriculture

- Development including roads, URL boundaries, etc.

- Topography

GIS allows the Conservancy to view one or more characteristic at the same time to see where they are located within the Conservation Area, their relationship with other landscape characteristics and includes some assumptions regarding the accuracy of the data. Most of the data was acquired from the County of San Luis Obispo's GIS database where some of the data, such as roads were last updated in 2005 . Other data, such as parcel ownership was last updated in 2008. It is assumed that there is little to no change in ownership within the Conservation Area between 2008 and 2011. The vegetation maps have a two-acre minimum mapping unit or margin of error compared to 
where attributes actually are on the ground (Aerial Information Systems 2009). Smaller areas such as wetlands and riparian areas have a smaller minimum mapping unit. The County of San Luis Obispo's vegetation data was derived from aerial photography, onthe-ground analysis and existing GIS data to increase the accuracy of the data.

\subsection{Aerial Photography}

The use of aerial photography is an important tool that was utilized to assess spatial and temporal landscape changes. Analysis of aerial photography helped to determine examples of where the Conservancy should focus potential restoration projects. Google Earth images from 2010 were analyzed to assess land uses with relationship to important landscape attributes such as rangelands, drainages, oak woodlands and potential places for development.

The resolution of the images limited the level of detail in which imagery could be analyzed. For example, in-stream channel characteristics such as pool-riffle dynamics could not be determined using available imagery and therefore inhibited the ability to determine specific project locations. Changes in vegetation and land use also occur over time. While Google Earth photographs are from 2010 satellite imagery, temporal changes in vegetation and land use limit the ability to use the analysis in this plan over time. Seasonal changes in vegetation also limit the usefulness of aerial photography analysis.

\subsection{Interviews}

Interviews with three local landowners were conducted in the spring of 2011 in

order to identify the long-term goals, practices and the challenges associated with being a ranching family in San Luis Obispo County. The purpose was to gather a spectrum of landowner perspectives and understand the challenges associated with ranching 
operations within the Conservation Area. Information was collected and examined in order to understand the relationships between landowner values, land management, and perceptions relating to conservation and stewardship.

Understanding landowner values, challenges and perspectives at a local scale is important to the Conservancy's mission of protecting the land and the people who work the land within San Luis Obispo County. The potential complexity and extent that conservation agreements can be negotiated makes understanding landowner needs an essential component of private land conservation planning. In-depth interviews with landowners within the Conservation Area provide insight and can help to establish relationships that could inform future project ideas.

The following is a description of the interview process including how interviewees were contacted, how data was collected and was used in the plan. Bob Hill, Executive Director of the Land Conservancy of San Luis Obispo County, initially contacted ranch operators, the principle investigator of this project made a follow-up call. Then, in-depth interviews were conducted with each of the interview participants. The general interview guide approach to in-depth interviews was used as the standard interview format. The in-depth interviews followed a semi-structured interview approach where guiding questions were developed beforehand. Aside from a few guiding questions, the interviews were primarily observational (Myers and Newman 2007). Interviews lasted between thirty minutes and one hour. Interviewees were asked to respond to a series of questions (See Appendix L). This approach ensured that the same general areas of information were collected from each of the interviewees, but allowed flexibility in the responses from the landowners. Follow-up questions were asked to encourage a more detailed response on particular questions. The interviewer using an audio recording device and hand-written notes collected the information.

The list of landowners interviewed is not an exhaustive list of landowners within 
the Conservation Area. All the interviewees have had previous communication with the Land Conservancy of San Luis Obispo County to varying degrees. Information gathered from the interviews was transcribed, analyzed and incorporated into the Conservation Area plan by informing conservation recommendations. The emphasis was on large tract landowners who had cattle operations on their land.

Due to the potentially sensitive nature of private land conservation, steps were taken to ensure confidentiality and privacy to the landowners being interviewed.

Appendix $\mathrm{K}$ is a copy of the confidentiality agreement signed by the interviewer and the landowners that were interviewed. 


\subsection{Background}

This chapter describes the setting that makes up the Conservation Area including a brief description of the history of people in the region, and existing conditions such as geology, soils, hydrology, vegetation, wildlife and land use.

\subsection{Geographic Setting}

The Upper Salinas Conservation Area is located in San Luis Obispo County, just south of Atascadero and east of the City of San Luis Obispo. There are two small, unincorporated areas within the Conservation Area; Santa Margarita and Pozo, located in the northwestern and southeastern parts of the Conservation Area, respectively. The California Rangeland Conservation Coalition identified much of the private land within the Conservation Area as having important ecological and cultural value.

Variable terrain including rugged mountains, rolling hills and intermittent valleys form the topography of the Upper Salinas River basin. Surface water generally drains northwards toward Monterey County. Several headwater tributaries flow across the Conservation Area as they drain into the Salinas River above and below the Salinas Dam. Urban development and a few mining and raw material processing land uses exist along the Salinas River (San Luis Obispo County 2010).

The Conservation Area is located between the Santa Lucia mountain range to the west and the La Panza mountain range to the east. The Garcia mountain range is located to the immediate south of the Conservation Area. Los Padres National Forest has jurisdiction of much of the land immediately surrounding the Conservation Area. There are over 10,300 acres of federally owned public land under management of the Los Padres National Forest within the Conservation Area. There are also small, county state and Bureau of Land Management owned properties within the Conservation Area. Figure 3.1 is a map of the location of the Conservation Area. 
Figure 3.1 Conservation Area location

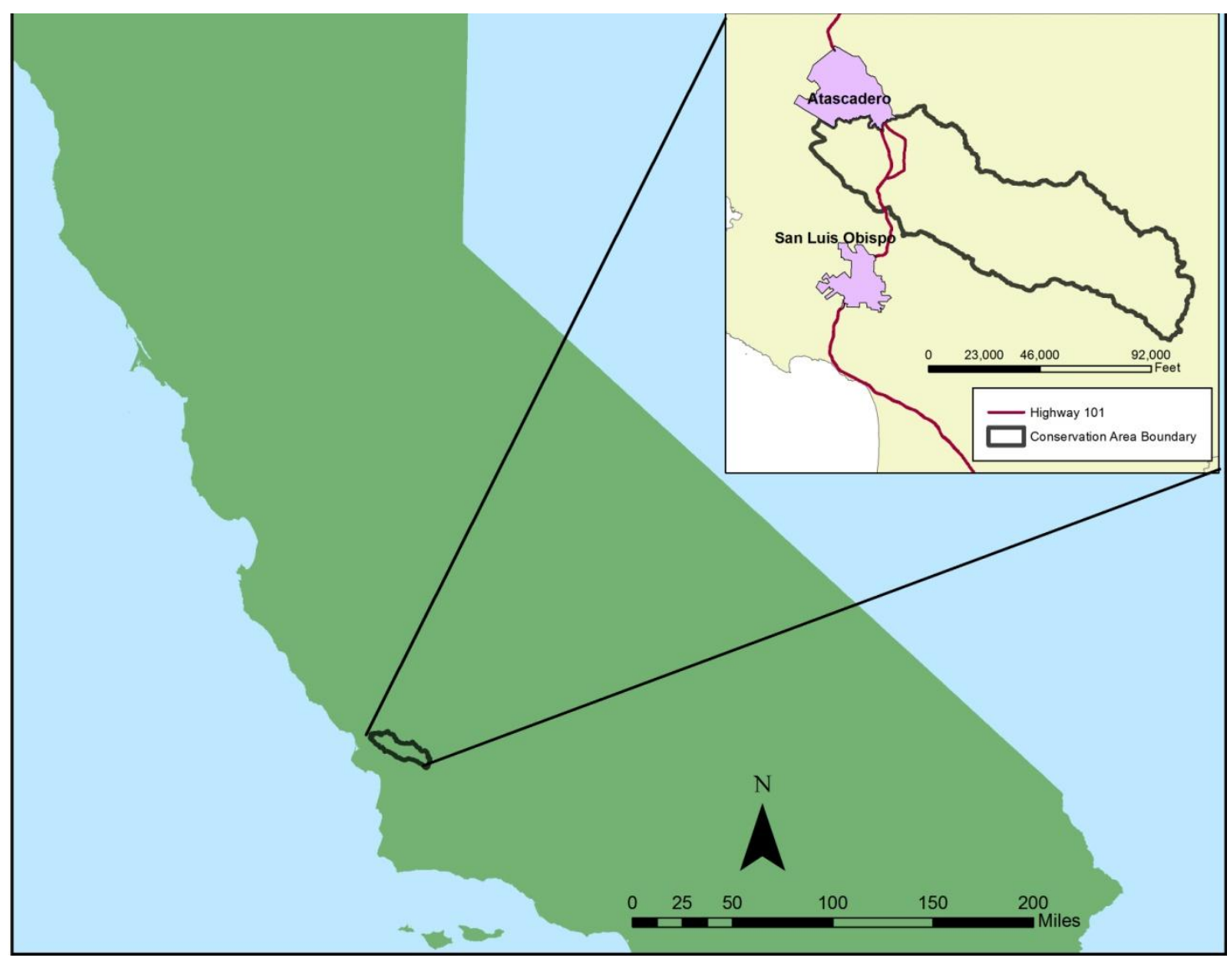

\subsection{Pre-History}

The Conservation Area and the surrounding region have a rich history of settlement from the Chumash Tribe, to Spanish Missionaries, to post Spanish settlement by farming and ranching families. Chumash settlements in the San Luis Obispo region were comparatively smaller than the settlements in and around Santa Barbara. The smaller Chumash settlements in the region supported a more mobile lifestyle and as a result had greater access to inland resources (Roper et al.. 1997). The region consists of historically overlapping boundaries of the Salinan to the north and Chumash people to the south. The Salinan and Chumash people had trade relationships with each other as well as with other more inland tribes (Daniel 1986). Generally, the Chumash people 
occupied lands from Santa Margarita Ranch south and west, while the Salinan occupied lands along the northern coast to the mid ridges of the coastal range. It is thought that the Salinan people may have occupied areas from Soledad to the City of Atascadero. Both the Northern Chumash and Salinan people lived in permanent villages along major inland drainages and on the coast. They did not occupy the rugged terrain of the Coast Range.

\subsection{European History}

Spanish Missionaries began settling and building missions in the area in the 1700's. The mission at San Luis Obispo was established in 1772 and within 10 years crops and livestock were established in the Santa Margarita Valley. The 1822 Informe, the Mission of San Luis Obispo's Annual Report, stated that a Santa Margarita asistencia was established to provide support to the main mission community in San Luis Obispo by raising wheat and livestock. It also provided a refuge in case of attacks on the mission (Webb 1952). An asistencia was a smaller scale mission but did not have a resident priest. In the 1820's, control of the asistencia resumed under the Mission at San Miguel due to the decline in population at Mission San Luis Obispo de Tolosa. As a result, Salinan Indians from the northern San Miguel area gradually replaced the Chumash as workers on the asistencia (Rincon Consultants, Inc. 2008).

Lands in the Santa Margarita Valley were granted to Joaquin Estrada in 1841 after Mexican Independence from Spain and the missions were no longer in use. Estrada owned Santa Margarita Ranch and it became an important social, political and economic center in the region. Cattle ranching became an increasingly important economic driver for Mexican ranchers in the mid 1800's.

In 1861 Estrada sold the ranch to Martin Murphy, Jr. Then in 1889, Murphy granted the Southern Pacific Railroad a right-of-way through the ranch and donated 640 
acres for the town site of Santa Margarita. In Santa Margarita, the railroad established a depot, roundhouse, warehouse, spur lines, and wells for water. Santa Margarita was initially a successful town providing the necessary amenities for railroad construction workers. Santa Margarita's population declined after the railroad was completed and has remained a small town since that time (Rincon Consultants, Inc. 2008).

\subsection{Cultural Resources}

Cultural resources in the area serve as important historical records of the region's history. Archaeological evidence suggests that coastal San Luis Obispo County was occupied as early as 10,000 years ago (Greenwood 1972 and Fitzgerald 2000). Sites dating back to 6500-3500 B.C. ranged from small intermittently dispersed "taskspecific" sites to temporary camps to large villages. There is evidence of the vicinity being continuously occupied for the past 10,000 years. The unique cultural landscape is a result of a combination of the cultural remains in the region and the natural environment of the Santa Margarita Valley. This region was shaped by American Indian, Spanish, Mexican, and Euro-American influences that historically encompassed areas around the Upper Salinas River basin (Rincon Consultants, Inc. 2008).

\subsection{Climate}

The regional climate generally follows a Mediterranean regime consisting of hot dry summers and cool wet winters. Several microclimates exist in the region creating climate diversity that is dependent on a number of variables including precipitation, topography and temperature. Situated between two coastal mountain ranges, the Conservation Area receives an average of 34 inches per year. February is the wettest month and has a recorded average precipitation of 5.41 inches. July has the lowest average precipitation of 0.03 inches. Temperature varies depending on the time of the 
year. August is the hottest month with an average high temperature of 82 degrees Fahrenheit and an average low of 53 degrees F. December has the coolest temperature with an average high temperature of 65 degrees $F$ and an average low of 42 degrees $F$.

\subsection{Geology}

For millions of years the Pacific Plate pushed eastward under the North American Plate along a subduction zone creating a variety of metamorphic and sedimentary rock formations that make up the diverse landscape. Sediments and debris from the eastward push of the Pacific Plate has resulted in complex geologic formations of the central coast (Chipping 1987). Figure A.1 in Appendix A is a map of the geological formations within the Conservation Area.

San Luis Obispo County generally falls within the mountainous area commonly known as the Coast Range. The county is divided into three geographic locations by two northwesterly faults. The central province, the region where the Conservation Area is located, is framed from the northeast by the San Andreas Fault and by three sections of the Rinconada Fault System in the southwest. (San Luis Obispo County 2010)

The central province is bounded on the northeast by the San Andreas Fault zone and on the southwest by three segments of the Rinconada Fault System. The bedrock is composed of Cretaceous and Jurassic-age granite, which has been relatively structurally stable throughout time. Proof of this is indicated by the lack of deformation of the younger sedimentary rock layers above it (San Luis Obispo County 2010). The topography generally consists of rolling hills to steep slopes ranging between thirty to seventy-five percent.

The diversity of geologic formations creates a variety of topographic features within the Conservation Area. The area is nestled between the Pacific Coast on the west and the San Andreas Rift Zone on the east. The Conservation Area is within the 
southern Coast Ranges San Luis Obispo County in the Coast Range Geomorphic Province. This area has a central, complex, alluvial valley consisting of low lying hills surrounded by higher bedrock mountains as well as the Salinas River (Rincon Consultants, Inc. 2008). The overall geologic structure is largely oriented in a northwesterly direction as proof by several of the tributaries to the west of the Salinas River draining to the northwest and tributaries to the east of the river draining to the northeast.

Slopes within the Conservation Area vary from 1 percent to over fifty percent. Elevations range from forty-nine feet to 254 feet above sea level with an average elevation of 231 feet. Alluvial deposits largely occupy the lower portions of the valleys, the older uplifted ranges, river terraces, and floodplains.

Slopes can have an effect on what types of land uses occur at a site. The Natural Resources Conservation Service (NRCS) lists descriptions of how slopes affect land uses. A short list of these descriptions includes (NRCS 2011):

- Agricultural crops are moderately affected when slopes exceed ten percent.

- $\quad$ Some crops can be sufficiently produced on slopes of thirty percent or more.

- Grassland used for grazing purposes may have moderate limitations above 30 percent depending on the local soil characteristics.

- Slopes of fifty percent or greater have a significant impact on the ability to graze these areas, although certain grazing management practices can reduce these impacts.

According to the County of San Luis Obispo's Agricultural Element (2010), approximately sixty percent of the County has a slope of thirty percent or greater. Twenty-three percent of the landscape falls within the ten to thirty percent slope range. 
This means that about seventeen percent of the County land area is comprised of slopes less than ten percent. Slopes also contribute to development potential. With the lack of gentle sloping land area, there is the potential for competition for land on slopes less than fifteen percent (San Luis Obispo County 2010).

\subsection{Soils}

Soils are an important characteristic and one of the primary factors that determine what vegetation can grow in a particular area. The Natural Resource Conservation Service (NRCS) has developed a classification system for soils that categorizes the ability to utilize the land for different types of agriculture including ranching (NRCS 2011). Figure A.2 in Appendix A is a map of the soil types in and around the Conservation Area. Soil types found within the Conservation Area were examined to identify "Prime" and "Non Prime" agricultural land. In accordance with the County of San Luis Obispo's General Plan and as part of the mission of the Land Conservancy, identifying potential projects to protect important agricultural land is considered a priority for conservation.

The farmland classification system is composed of four main categories: Prime Farmland, Non-Prime Farmland, Farmland of State Significance and Farmland of Local Significance defined by the Natural Resource Conservation Service (NRCS 2011). Each soil designation is defined by the soil type and ability to grow certain crops with different degrees of limitations, restrictions, ability to hold and drain water, etc. The following is a general description of the four agricultural soil classifications as defined by the NCRS (2011) and summarized by the County of San Luis Obispo's General Plan (2010): 
Farmland of Significant State Importance is defined as "land other than Prime

Farmland which has a good combination of physical and chemical characteristics for the production of crops" (NRCS 2011). Farmland of Significant State Importance includes the following criteria for consideration:

- Water

- Soil temperature range

- Acid-Alkali balance

- Water table
- Soil sodium content

- Erodibility (k value)

- Rock fragment content

Prime Farmland soils are required to have irrigation capability and are also referred to as "prime soils". This class of soils has few limitations that restrict their use. According to NRCS "Prime Farmland is land that has the best combination of physical and chemical characteristics for producing food, feed, forage, fiber, and oilseed crops and that is available for these uses. It has the combination of soil properties, growing season, and moisture supply needed to produce sustained high yields of crops in an economic manner if it is treated and managed according to acceptable farming methods" (NRCS 2011). These soils are typically utilized for vegetables, seed crops, orchards, and other irrigated specialty crops and irrigated field crops.

Prime Farmland if Irrigated and Drained soils have moderate to severe limitations that reduce the choice of plants, and/or that require special conservation practices. These soils are commonly used for vineyards.

Non Prime Farmland soils have severe limitations that make them generally unsuitable for cultivation. These soils have commonly been used for rangeland and dryland grain production. They are not likely to erode, but have other limitations, impractical to remove, that limit their use. 
Eighty-eight percent of the landscape is on Non-Prime Farmland. Due to the terrain and soil types, some lands within the Conservation Area are unusable for any type of agriculture. Soil types that support grassland but are not considered prime farmland are often utilized as grazing land for cattle. Approximately 16,892 acres or a combined percentage of twelve percent of the landscape is considered both prime agricultural land if irrigated and agricultural soils of state significance. Table A.17 below shows how much prime, non-prime, and state significant agricultural soils are within the Conservation Area. Much of the state significant and prime farmland if irrigated is located on private land within the Conservation Area. These lands are located primarily on the north and west sides of the Salinas River terrace and along its tributaries of the Salinas River, primarily in the south-southeast. Many of the major roads traversing the Conservation Area intersect or pass alongside these soils. Highway 58, Pozo Road, and Parkhill Roads run adjacent to most of these agricultural lands, which demonstrates the relationship between higher intensity land uses (i.e. agriculture) on prime agricultural soil and major road networks in the Conservation Area. Two primary agricultural uses exist on lands within the Conservation Area in addition to rangeland grazing. They include vineyards and hay/dryland production. See Figure A.3 in Appendix A for a map of the prime and State significant agricultural soils. Table 3.1 shows the acres of the different agricultural classifications within the Conservation Area. 


\begin{tabular}{|lrr|}
\hline \multicolumn{3}{|c|}{ NRCS Farmland Soil Classification } \\
\hline Classification & \multicolumn{1}{c|}{$\begin{array}{l}\text { Area } \\
\text { (acres) }\end{array}$} & $\%$ Area \\
\hline Non-Prime Farmland & $122,539.3$ & $87.83 \%$ \\
\hline Prime Farmland if Irrigated & $11,660.5$ & $8.36 \%$ \\
\hline $\begin{array}{l}\text { Farmland of Special State } \\
\text { Significance }\end{array}$ & $5,232.4$ & $3.75 \%$ \\
\hline $\begin{array}{l}\text { Prime Farmland if Irrigated and } \\
\text { Drained }\end{array}$ & 87.8 & $0.06 \%$ \\
\hline Total & 139,520 & $100.00 \%$ \\
\hline
\end{tabular}

Table 3.1 NRCS Farmland Soil Classification

Much of the rangeland within the Conservation Area is utilized for livestock grazing due to its subprime agricultural soils and abundance of perennial and annual grasses. Both prime agricultural land and rangeland exist primarily on the river terrace of the Salinas River and in small sections of the Santa Lucia foothills. There is also a significant amount of prime agricultural land within the floodplains of Pozo and Toro Creeks. Larger tract private landowners own much of these areas. Of those landowners, all of them have an operating cattle ranch on the land and at least three of them have a twenty-acre or greater vineyard and utilize ground water irrigation to water their crops.

\subsection{Hydrology}

\subsubsection{Subwatersheds}

The Upper Salinas Watershed within the Conservation Area is comprised of seventeen sub-watersheds. All of the sub-watersheds drain into the Salinas River. Land uses and management practices in the sub-watersheds play a pivotal role in the supply and quality of water that originates in these areas but ultimately affects the greater Salinas River basin. Changes to higher intensity land uses such as 
urban/exurban and agricultural development can dramatically change the hydrological and morphological characteristics of the landscape. These changes can have detrimental impacts on the supply and quality of both surface water and ground water systems.

The Conservation Area contains many sub-watersheds that make up the larger Upper Salinas Watershed area. The Upper Salinas Watershed extends northward into Monterey County. There is approximately 141,615 acres or 221.27 square miles of drainage area within the Conservation Area. The names and locations of each subwatershed are illustrated in Figure A.4 in APPENDIX A. The Paloma Creek subwatershed extends beyond the Conservation Area; therefore the total drainage area within the Conservation Area is slightly bigger than the Conservation Area itself. Table 3.2 shows the total acreage and relative size compared to the rest of the Upper Salinas Watershed within the Conservation Area. Each sub-watershed outlines the major drainages that flow into the Salinas River. 


\begin{tabular}{|c|c|c|}
\hline Subwatershed Name & $\begin{array}{c}\text { Drainage } \\
\text { Area (Acres) }\end{array}$ & $\%$ Area \\
\hline $\begin{array}{l}\text { Santa Margarita } \\
\text { Creek }\end{array}$ & 16,032 & $11.3 \%$ \\
\hline Hale Creek & 12,860 & $9.1 \%$ \\
\hline Santa Margarita Lake & 10,564 & $7.5 \%$ \\
\hline Rincon Creek & 9,960 & $7.0 \%$ \\
\hline Trujillo Creek & 9,866 & $7.0 \%$ \\
\hline Coyote Hole & 9,612 & $6.8 \%$ \\
\hline Yaro Creek & 9,402 & $6.6 \%$ \\
\hline Douglas Canyon & 8,353 & $5.9 \%$ \\
\hline Horse Mesa & 8,243 & $5.8 \%$ \\
\hline American Canyon & 8,229 & $5.8 \%$ \\
\hline Pozo Creek & 2,870 & $2.0 \%$ \\
\hline Paloma Creek* & 7,928 & $5.6 \%$ \\
\hline Trout Creek & 7,926 & $5.6 \%$ \\
\hline Calf Canyon & 5,756 & $4.1 \%$ \\
\hline Pilitas Creek & 5,355 & $3.8 \%$ \\
\hline Alamo Creek & 4,581 & $3.2 \%$ \\
\hline Moreno Creek & 4,078 & $2.9 \%$ \\
\hline $\begin{array}{l}\text { Unnamed Sub- } \\
\text { watershed }\end{array}$ & 8,094 & $5.7 \%$ \\
\hline Total Drainage Area & 141,615 & $100.0 \%$ \\
\hline
\end{tabular}

${ }^{*}$ Paloma Creek sub-watershed is not entirely within the Conservation Area Boundary. The subwatershed has been significantly altered from its natural state due to the presence of the City of Atascadero

Table 3.2 Upper Salinas Sub-watersheds within the Conservation Area 


\subsubsection{Rivers and Streams}

This project focuses on the headwaters of the Upper Salinas Watershed, surrounding Santa Margarita Reservoir. The Salinas River drains 4,170 square miles and flows approximately 170 miles north from central San Luis Obispo County to the mouth in Monterey Bay, south of Castroville, CA (Funk and Morales 2003). The State Water Resources Control Board lists the Salinas River as a "Category I, Impaired Watershed" and is one of the most critically degrading rivers due to non-point source pollution factors (Las Tablas-Upper Salinas Resource Conservation District 2002). The surface water and extensive ground water system of the Upper Salinas Watershed provides viable water supplies to many municipalities and farming operations in the region including: San Luis Obispo, Paso Robles, Atascadero, Santa Margarita, Shandon, San Miguel and Templeton. The headwaters support a multi-billion dollar agricultural industry throughout the entire Salinas River basin from San Luis Obispo County to Monterey Bay. Development and water use in the region have already had detrimental effects on water supply, quality, habitat and other ecosystem functions (Funk and Morales 2003). This development and potential future growth place pressures on water systems and habitat in the region providing the justification for the need to protect and enhance the ecological and hydrological functions on private rangeland within the Conservation Area.

There are many drainages varying in size located within the Conservation Area boundaries that all eventually flow into the Salinas River. These drainages include both named and unnamed headwater streams and tributaries as well as the main stem of the Salinas River. Alexander et al. (2007) report that first-order headwater streams contribute approximately seventy percent of a system's water supply and a significant percentage of nitrogen loading. The study concludes that headwaters are part of the main channel nexus and play a significant role in the potential transport of pollutants 
affecting water quality downstream. Changes in land use i.e. development and agricultural intensity have the potential to increase peak flows and downstream pollutants (Allan 2004). In a region that is heavily dependent on a quality supply for agricultural and municipal purposes, protecting the Salinas River headwaters is essential. Headwater streams account for approximately two-thirds of the total stream length and are essential in maintaining hydrologic connectivity. Hydrologic connectivity is the way in which water transports energy, matter and biota at different stages of the hydrologic cycle (Freeman et al.. 2007).

Major tributaries to the Salinas River within the Conservation Area are listed in Table 3.3. Descriptions of where they are located and whether they originate and/or flow across public and/or private land are also listed. Strahlers stream classification system was used to assess stream order of each tributary listed using Google Earth Images from 2010. Streams with no tributaries were considered a one, two-ones that joined together becomes a second order stream and so on. Many headwater streams (primarily first order streams) are ephemeral streams and several are unnamed. Regardless of whether streams are seasonal or not, they provide essential nutrient, hydrologic and energy movement downstream. Stream systems at equilibrium have naturally balanced ebb and flow cycles of material and energy flow downstream (Rosgen 1994). Disturbances to these systems can increase flow rates, sedimentation, erosion, and degrade important habitat features for riparian and in stream species. These factors affect the ability of the systems downstream to get back to equilibrium (Rosgen 1994). Degraded upland areas can cause concentrated runoff that may reduce the effectiveness of riparian vegetative buffers to provide a natural sediment filtration system. It can also help to establish competitive invasive or upland plants. On the other hand, healthy riparian areas can filter sediments, capture and slow down water runoff, 
degrade some chemical toxins, recycle nutrients, and intercept and decrease pathogens (Bellows 2003).

Assessment of existing and potential land uses near stream systems offer some indications of the degree and types of disturbances on stream systems. The State Regional Water Quality Control Board lists several sources of pollution in the Central Coast Region Basin Plan, which the Upper Salinas River is categorized into, including sedimentation and a number of non-point source chemical and biological pollutants. The Monterey Bay Sanctuary Citizen Watershed Monitoring Network and the Coastal Watershed Council held annual region-wide water quality monitoring events that captured a number of physical, chemical and biological parameters to measure water quality of the streams and creeks throughout the Salinas River Basin. Most of the sites monitored, including main tributaries within the Conservation Area met water quality standards outlined in the Regional Water Quality Control Boards Basin Plan standards. According to data collected by the Regional Water Quality Control Board, the Monterey Bay Sanctuary Citizen Watershed Monitoring Network, Las Tablas-Upper Salinas Resource Conservation District and the Coastal Watershed Council the headwaters within the Upper Salinas Watershed are considered to be in fairly pristine condition due to available open space and lack of development. However more intensive and consistent data collection is needed in the Upper Salinas Watershed region to understand changes in stream/river hydrology, morphology and biology to help further address water quality and supply issues.

Tributaries drain from the Santa Lucia and Los Padres mountain ranges, over the foothills and into the relatively narrow valley where they drain into the Salinas River, which opens up more as the Salinas River moves north. 


\begin{tabular}{|c|c|c|}
\hline Tributaries & Order & Description \\
\hline \multicolumn{3}{|c|}{ West Side of the Salinas River } \\
\hline Trout Creek & $2+$ & $\begin{array}{l}\text { Originates on public land, traverses } \\
\text { Property Ten and Property Fourteen. } \\
\text { Merges into Santa Margarita Creek at the } \\
\text { heavily subdivided area near the } \\
\text { Atascadero URL }\end{array}$ \\
\hline Tassajara Creek & 2 & Converges into Santa Margarita Creek \\
\hline Santa Margarita Creek & 3 & $\begin{array}{l}\text { Originates on public land, crosses smaller } \\
\text { parcels and Property Ten. Empties out on } \\
\text { subdivided ranchettes into Salinas River. } \\
\text { Has documented steelhead breeding } \\
\text { habitat }\end{array}$ \\
\hline Yerba Buena Creek & 2 & $\begin{array}{l}\text { Originates on Property Ten and empties } \\
\text { into Santa Margarita Creek }\end{array}$ \\
\hline Atascadero Creek & 3 & $\begin{array}{l}\text { Originates on public land and traverses } \\
\text { across Property Sixteen into Atascadero. } \\
\text { Has known steelhead breeding habitat }\end{array}$ \\
\hline Rinconada Creek & 3 & $\begin{array}{l}\text { Originates and traverses Property Nine. } \\
\text { Transects some smaller parcels and } \\
\text { empties into Salinas below Santa } \\
\text { Margarita Reservoir }\end{array}$ \\
\hline Salsipuedes & 3 & $\begin{array}{l}\text { Originates on public land and traverses } \\
\text { smaller parcels emptying into Santa } \\
\text { Margarita Reservoir }\end{array}$ \\
\hline Hale Creek & 2 & $\begin{array}{l}\text { Originates on public land, crosses } \\
\text { Property Sixteen and converges with } \\
\text { Atascadero Creek within the Conservation } \\
\text { Area. Lower Hale Creek has documented } \\
\text { steelhead breeding habitat }\end{array}$ \\
\hline Paloma Creek & 1 & Originates on Property Sixteen \\
\hline Burrito Creek & 2 & Tributary of Rinconada Creek \\
\hline
\end{tabular}




\begin{tabular}{|c|c|c|}
\hline \multicolumn{3}{|c|}{ East Side of the Salinas River } \\
\hline American Canyon Creek & 2 & $\begin{array}{l}\text { Originates on public land and transects in } \\
\text { and out of Property One entering Salinas } \\
\text { River on that property }\end{array}$ \\
\hline Pozo Creek & 3 & $\begin{array}{l}\text { Starts on public land flows across smaller } \\
\text { parcels of private land onto the Property } \\
\text { Six property across smaller parcels of } \\
\text { private land and onto Property Five where } \\
\text { it empties into the Salinas River }\end{array}$ \\
\hline Toro Creek & 3 & $\begin{array}{l}\text { Starts on public land and Property Seven. } \\
\text { A first order does cross some of the } \\
\text { Property Six, crosses smaller parcels of } \\
\text { private land and empties into the Salinas } \\
\text { River just above the Santa Margarita } \\
\text { Reservoir }\end{array}$ \\
\hline Alamo Creek & 2 & $\begin{array}{l}\text { Originates on smaller parcels of private } \\
\text { property, crosses public land and empties } \\
\text { into the Santa Margarita Reservoir }\end{array}$ \\
\hline Pilitas Creek & 3 & $\begin{array}{l}\text { Headwater streams originate on Property } \\
\text { Eight and much of it traverses smaller } \\
\text { parcels of private property ultimately } \\
\text { emptying into the Salinas River at the } \\
\text { boundary of smaller private land parcels } \\
\text { and Property Nine }\end{array}$ \\
\hline Yara Creek & 2 & Tributary to Toro Creek \\
\hline Parkhill Creek & 2 & Tributary to Toro Creek \\
\hline
\end{tabular}

Table 3.3 Streams and stream orders 
Water resources within the Conservation Area provide important nutrient and energy cycling functions as well as in stream and riparian habitat. Protection of these resources is largely dependent on a combination of public and private land conservation practices. Long-term conservation ensures that harmful land uses are prohibited. It is a priority of this plan to protect water resources within the Conservation Area. Water in this region is essential to agricultural viability (including ranching) within the watershed and downstream of the Conservation Area.

In a study by Jackie Crim (2007), development intensity increases total dissolved solid and other pollutants as well as increased peak flows that correspond to storm events. The study also concluded that well managed rangelands had stable peak flows and lower in-stream pollutants. This suggests that working rangeland in the Conservation Area can provide ecosystem services relating to water quality, while development pressures on the landscape degrade the hydrologic connectivity. Rangelands soils and vegetation help to filter out pollutants. This has the potential to affect the costs and manner in which municipal water agencies must address providing quality water to its residents (Postel and Thompson 2005).

The value of protecting rangeland in the Upper Salinas Watershed from future development is exemplified in the Watershed Protection Program run by the New York City Department of Environmental Protection. In the 1980's, in order to protect municipal water supplies, the City made investments to perpetually protect the sources of their water supply; the watersheds in the Catskill Mountains (Pires 2004). The Department of Environmental Protection used acquisitions and conservation easements in partnership with private landowners to ensure perpetual watershed protection in order to secure a safe water source for the residents of New York City and surrounding suburbs. Private rangelands in the Conservation Area serve a similarly important role in protecting the greater Upper Salinas Watershed. Land protection in the Conservation Area would keep 
large intact landscapes free from intense land use development, allowing the natural processes to keep the water supply healthy and safe. New York City and several other municipalities around the country and the world find it more economically plausible to make long-term land conservation investments rather than make perpetual investments in technological upgrades to keep water supplies safe (Pires 2004 and Postel and Thompson 2005).

Areas within the Upper Salinas Watershed also act as a ground water recharge source as well as a source of surface water. This is important considering the onset of climate change impacts on water supply in an already hydrologically fragile region. Water pressures from agriculture, rural and urban cores place pressures on fragile water supplies from the Salinas watershed and the ground water below. As decreased water supplies are predicted under changing climates, it is important to protect and plan existing water supplies to ensure adequate availability into the future. Protection of landscapes within the Upper Salinas Watershed is also important to riparian and fish habitat. Protecting surface and ground water from problems relating to water quality and quantity at the watershed scale requires four considerations:

- Preserving intact landscapes through long-term conservation

- Implementing sustainable land management practices and

- Identifying and employing enhancement projects.

- Establishing county planning mechanisms to ensure that future development has a minimal impact on watershed functions 
Figure A.5 in Appendix A shows perennial tributaries to the Salinas River. Most of the land area that the rivers traverse within the Conservation Area occurs on private land. With the exception of Alamo Creek, all major tributaries pass through at least one of the large properties identified in Figure A.4 in Appendix A. Many of the tributaries originate in the upper headwaters, mostly on public land and as they move down the drainage, traverse private property as they drain into the Salinas River. Increases in intense land use development can negatively affect water supply (increased use), water quality (impervious services, chemical treatments, loss of riparian buffers, sedimentation) and riparian and in-stream habitat (decrease in riparian vegetation, changes in stream morphology and structure and chemical changes) (Barrios 2000). Table 3.3 lists each major stream and creek that flows into the Salinas River, their order, and relationship to public and private land.

There are several larger tributaries of the Salinas River that traverse private property. Pozo Creek and the Salinas River converge on Property Five upstream of the reservoir. Toro Creek traverses smaller private land parcels until it reaches the Reservoir on public land. Pilitas Creek converges with the Salinas River below Santa Margarita Reservoir on Property Nine after traversing several smaller parcels of private property. Burrito Creek also joins Rinconada Creek on Property Nine. Yerba Buena Creek joins Santa Margarita Creek on Property Ten. Development on the Santa Margarita Ranch is proposed to go between Trout Creek and Yerba Buena Creek, most likely intersecting important tributaries to these creeks. The Salinas River itself enters the Conservation Area traversing both public land and on Property One. It then crosses smaller parcels eventually meandering on the border of public land and Property Three and Property Five. From there, the river crosses public land, forms Santa Margarita Reservoir and flows across primarily small individually owned parcels. The Salinas 
River exits in the Conservation Area river valley directly adjacent to Property Fifteen, southeast of Atascadero.

\subsubsection{Ground water}

The complexity of the rock formations of the region has created several ground water basins that are linked to the surface water hydrology. Many of the larger ground water basins inland are contained in the older alluvium deposits (San Luis Obispo County 2010). The ground water basins within the Conservation Area include: Rinconada Valley, Pozo Valley and Salinas Valley ground water basins. Several vineyards have replaced rangeland in some places within the Conservation Area. Due to increased water use in the region the ground water supplies are being increasingly over drafted. Figure A.5 Appendix A shows the different ground water basins within the Conservation Area. According to the San Luis Obispo County General Plan (2009) the ground water basins in the Upper Salinas Watershed (including the Conservation Area) have a total storage capacity of $30,062,000$ acre-feet, with a usable storage of $26,522,000$ acre-feet. The estimated dependable ground water supply is approximately 48,000 acre-feet per year. These figures do not take into account the effects of climate change on recharge areas and other hydrologic systems that may impact water availability.

\subsection{Vegetation}

The vegetation communities within the Conservation Area are an essential component to ensuring a clean source of water, important habitat, beautiful views and economic viability via livestock production (Las Tablas-Upper Salinas Resource Conservation District 2004). Development, fragmentation and poor rangeland management can reduce the capacity of these landscapes to provide these essential 
services (California Department of Forestry and Fire Protection 2010). For example, structural development can result in the creation of more impervious services on landscapes that were previously rangeland resulting in a decrease in the ability for watershed functions to properly capture and allow for ground water infiltration and recharge (California Department of Forestry and Fire Protection 2010). Figure A.6 in Appendix A is a map of the different types of vegetation cover within the Conservation Area. A list of plant species from the California Natural Diversity Database and the Santa Margarita Ranch Agricultural Residential Cluster Subdivision EIR (2008) can be found in Table B.1 in Appendix B

Most of the tree, herbaceous vegetation, riparian vegetation, meadows and wetlands occur in the riverine terrace and floodplain areas of the Salinas River. Tree and riparian vegetation also occur in the higher elevations along the tributaries of the Salinas River. Most of the shrub habitat occurs in higher elevation and more rugged terrain of the Santa Lucia and Los Padres mountain ranges. Table 3.4 shows the total acreages and percent of each vegetation type within the Conservation Area. Vegetation communities common in the Conservation Area include: Native perennial grassland, California annual grassland, central (Lucian) coastal shrub, chamise chaparral, blue oak woodland, coast live oak woodland, mixed oak woodland, riparian/riverine, emergent wetland, and some interspersed ephemeral pools. Each of the vegetation communities are described in the sections below (Rincon Consultants, Inc. 2008). Vegetation information was collected from a number of sources including the Santa Margarita Ranch Agricultural Residential Cluster Subdivision Environmental Impact Report (EIR) (Rincon Consultants, Inc. 2008). Some of the data collected for this section was gathered from the Santa Margarita Ranch EIR and was collected from a small portion of the Conservation Area on Santa Margarita Ranch and may not fully represent the biota present within the entire Conservation Area. It is assumed that the vegetation types and 
wildlife found on Santa Margarita Ranch are similar to those found throughout the Conservation Area.

It is not uncommon for these vegetation communities described below to overlap as they change from one to the other throughout the Conservation Area. For example, rangeland is potentially considered both grassland and mixed oak woodlands that may have understory grasses. Chaparral and Central Coastal Shrub communities also mix and can be found immediately adjacent to each other.

\begin{tabular}{|lcc|}
\hline Vegetation Type & Acres & $\%$ Area \\
\hline Mesomorphic Tree Vegetation & 42036.56 & $30.13 \%$ \\
\hline Mesomorphic Shrub Vegetation & 66825.13 & $47.90 \%$ \\
\hline Mesomorphic Herbaceous Vegetation & 21225.92 & $15.21 \%$ \\
\hline Temperate Flooded Riparian Vegetation & 2161.72 & $1.55 \%$ \\
\hline $\begin{array}{l}\text { Temperate Meadow and Vegetated } \\
\text { Wetland Area }\end{array}$ & 168.50 & $0.12 \%$ \\
\hline $\begin{array}{l}\text { Wetland Associated with Naturally Sparse } \\
\text { or Un-vegetated Areas }\end{array}$ & 118.32 & $0.08 \%$ \\
\hline Water & 802.87 & $0.58 \%$ \\
\hline Urban Build Up & 3341.00 & $2.39 \%$ \\
\hline Agriculture & 3005.56 & $2.15 \%$ \\
\hline Total acres & 139520.00 & $100.00 \%$ \\
\hline
\end{tabular}

Table 3.4 Vegetation Types

\subsubsection{Mesomorphic Tree Vegetation}

The National Vegetation Classification Hierarchy defines this category as locations where tree species make up at least eight to ten percent of the vegetative cover (The Nature Conservancy and Environmental Systems Research Institute 1994). There are approximately 42,036 acres of oak tree stands within the Conservation Area. See Table 3.5 for a list of acres per tree community stand type. Much of the tree 
communities within the Conservation Area are found on the terrace and existing floodplain/valley of the Salinas River and major tributaries. Beyond those areas, the shrub communities tend to dominate.

This region represents some of the historically prevalent, but now much less common oak savannah woodlands. Oaks are important because they provide cover, nesting, and a critical food supply in for the biodiversity of the region. They are also important in maintaining the soil structure, moisture content, the carbon cycle, energy equilibrium, and the nitrogen cycle in a complex ecosystem. Oaks in this region can exist as individual trees surrounded by herbaceous vegetation and/or in shrub vegetation or as varying numbers of oak or oak-mix hardwood stands. Rarer species of Canyon Oak are found in the region. Oaks are also considered part of the regional legacy important to people because it is the character of the region. Figure A.7 Appendix A is a map of Blue, Valley, and Canyon Oak stands from 2009 County of San Luis Obispo GIS data located in the Conservation Area. 


\begin{tabular}{|lccc|}
\hline Tree Stands & Acres & $\begin{array}{c}\% \text { of stands } \\
\text { relative to each } \\
\text { other }\end{array}$ & $\begin{array}{c}\% \text { of } \\
\text { Land } \\
\text { Area }\end{array}$ \\
\hline Non-oak species & 1479.57 & $3.52 \%$ & $1.06 \%$ \\
\hline $\begin{array}{l}\text { Coast Live Oak-Mixed } \\
\text { Hardwood }\end{array}$ & 2752.14 & $6.55 \%$ & $1.97 \%$ \\
\hline Coast Live Oak-Blue & 8740.80 & $20.79 \%$ & $6.26 \%$ \\
\hline Oak & & & \\
\hline Coast Live Oak & 10724.29 & $25.51 \%$ & $7.69 \%$ \\
\hline Valley Oak & 3534.85 & $8.41 \%$ & $2.53 \%$ \\
\hline Canyon Oak & 25.41 & $0.06 \%$ & $0.02 \%$ \\
\hline Blue Oak & 14779.50 & $35.16 \%$ & $10.59 \%$ \\
\hline Total acres & 42036.56 & $100.00 \%$ & $30.13 \%$ \\
\hline Total land area & 139520.00 & & $100.00 \%$ \\
\hline
\end{tabular}

Table 3.5 Tree stands within the Conservation Area

Coast live oak (Quercus agrifolia) occurs within the Conservation Area under two conditions: in moist-north facing slopes where they exist with shade tolerant understory species as well as with other hardwood species such as big leaf maple (Acer macrophyllum) and Madrone (Arbutus menziesii). The other condition where coast live oak exists is in drier exposed areas where oaks are scattered and associated with shrubby, herbaceous vegetation such as grassland. Coast live oak stands exist throughout the Conservation Area, but dominate slopes near streams, but not necessarily along the immediate riparian area. As the landscape increases in elevation coast live oak stands tend to mix with other plant communities, particularly hardwood tree species. Coast live oak in the Conservation Area is often in mixed-stand communities particularly, coast live oak-blue oak stands and to a lesser extent, coast live oak-mixed hardwood stands. See Figure A.8 in Appendix A for map of oak stands, including coast live oak in the Conservation Area. Stands with coast live oak making up 
all or part of the canopy make up over fifty-two percent of the total canopy located within the Conservation Area. This is equivalent to just over sixteen percent of the total land area within the Conservation Area. Of the large tracts of private land, Properties Eight, Nine, Ten, and Sixteen contain the highest percentages of coast live oak stands (as solely coast live oak, coast live oak-blue oak and coast live oak-mixed hardwood stands).

Blue oaks (Quercus douglasii) predominantly exist in areas surrounding Santa Margarita Reservoir and moving up the Salinas River primarily on the eastern side in the floodplains and terraces. Blue oak dominates the narrowing terrace, foothills and floodplains of the Salinas River in the southeastern tracts of private property particularly dominating the canopy on Property One and Property Two. Blue oaks also exist as mixed coast live oak-blue oak stands where conditions for both species exist as demonstrated in Figure A.8 in Appendix A. Blue oak stands can be found throughout the Conservation Area on both sides of the Salinas River, but tend to follow the Salinas River and up main tributaries. Dominant stands exist primarily in the terrace and in floodplains of the Salinas River and its main tributaries, but a few smaller stands exist along the smaller tributaries.

Valley oak stands occur on alluvial terraces and on rolling foothills from the Lake Shasta area to Los Angeles. They are usually found in alluvial valleys and can be found as foothill woodlands (Holland and Keil 1995). Within the Conservation Area, valley oak woodlands make up just over seven percent of the relative tree canopy cover and 2.5 percent of the total land area. The species occurs in sub-valleys and on former tributary floodplains, and on the Salinas River terrace. The majority of the stands exist north and west of Santa Margarita Reservoir.

According to the 2009 County Vegetation GIS data, valley oak is primarily located in smaller valleys and riparian areas on the north and western terrace of the 
Salinas River. They are also intermittently located in riparian areas along the tributaries of the Salinas River as well as along smaller stream orders that flow into Salinas River tributaries. See Figure A.8 in Appendix A for a map of valley oak locations within the Conservation Area. Small pockets of valley oak stands exist throughout the Conservation Area. Of the large properties identified, Properties Three, Six, Eight, Nine, Ten, and Sixteen contain the largest pockets of valley oak woodlands. There are significant stands to the north and east of the Salinas River primarily on small properties.

Canyon live oak (Quercus chrysolepis) is considered rare and exists within the Conservation Area. Small stands can be found throughout the County of San Luis Obispo. Within the Conservation Area, canyon live oak exists as one small pocket on public land south and east of the Salinas River closest to Property Five. See Figure A.8 in Appendix A for the location of canyon live oak stands within the Conservation Area.

Dominant oaks stands of coast live oak and blue oak can be found in riparian or floodplain stands along the Salinas River and in along tributaries of the Salinas River. One notable stand of both coast live oak and blue oak species exists adjacent to Pilitas Creek. The higher elevations tend to support the coast live oak-mixed hardwood stands and much of that occurs on public land west of the Salinas River. Properties Ten and Sixteen have the highest diversity of oak stands/oak species on the property. Many of the oak stands, with the exception of the coast live oak-mixed hardwood stands (although a few small intermittently dispersed stands do exist) can be found in valleys and floodplain areas and on the Salinas River terrace. Most of the large properties within the Conservation Area contain a large percentage of the oak stand diversity. As you move up the Salinas River, elevation increases and the terrain narrows. As a result, Property One is home to predominantly blue oak stands that have a fairly dense canopy. Valley oak species tend to exist within the floodplains of the Salinas River and its tributaries in intermittent-smaller sized stands. 


\subsubsection{Mesomorphic shrub vegetation}

Mesomorphic shrub vegetation is the dominant vegetation community in the Conservation Area. The National Vegetation Classification Hierarchy defines

Mesomorphic shrub vegetation where the dominant canopy consists of shrub vegetation, covering at least ten percent of a site. Trees may occupy eight to ten percent cover, but are not distributed evenly throughout the area (The Nature Conservancy and the Environmental Research Institute 1994). Drier shrub/scrub vegetation dominates the southwest facing slopes and the granite soils found within the Conservation Area (County of San Luis Obispo 2010).

Much of the shrub communities are located throughout the Conservation Area, but dominate in the higher reaches of the watershed. Figure A.16 in Appendix A shows different vegetation types including mesomorphic shrub vegetation. The rugged areas of the Santa Lucia and Los Padres mountain ranges are ideal for shrub communities consisting of hot and generally dry climate, where any available water is quick to drain off the rugged terrain. Shrub vegetation community makes up 68,825 acres, which is equivalent to about forty-eight percent of the land area within the Conservation Area. There are two dominant types of shrub vegetation communities; chaparral and central (Lucian) coastal scrub located within the Conservation Area. Often these communities coexist or are directly adjacent to one another. Both shrub/scrub community types provide important habitat for many bird, mammal and reptile species. The data available cannot distinguish between chaparral and coastal scrub vegetation types, but research gathered for the Santa Margarita Environmental Impact Report (Rincon Inc. 2008) lists the presence of chaparral and to a lesser extent coastal scrub. Much of the public land within and surrounding the Conservation Area is made up of shrub community vegetation. 


\section{Chaparral}

Chamise chaparral is the most common vegetation community in the Conservation Area. It primarily exists on steep dry slopes and the composition of species can vary greatly depending on the present dominant species. Generally, vegetation in this community grows densely and is drought-tolerant. Often the density of this plant community is prohibitive to understory growth (Holland and Keil 1995). Dominant species within this vegetative community include (Rincon Inc. 2008): chamise (Adenostomafasciculatum), big berry manzanita (Arctostaphylosglauca), buckbrush (Ceanothus cuneata), and buckwheat (Eriogonum spp.). Several other native herbaceous species can be found in chaparral shrub communities and are listed in Table 3.6.

\begin{tabular}{|l|l|}
\hline \multicolumn{2}{|c|}{ Common Chaparral Native Species } \\
\hline deerweed & red-spot clarkia (Clarkia speciosa), \\
\hline rock rose (Helianthemum scoparium), & holly-leaved navarettia, \\
\hline winecup clarkia (Clarkia purpurea), & Michael's rein orchid (Piperia michaelii) \\
\hline
\end{tabular}

Table 3.6 Common native herbaceous chaparral species

\section{Central (Lucian) Coastal Scrub}

"Coastal scrub communities are characterized by low shrubs and an absence of trees. Types of vegetation include either pure stands, or mixtures of low, thick-leaved evergreens and coarse, deciduous species that drop their leaves in response to periodic drought conditions" (California Environmental Resources Evaluation System 2011). Coastal scrub communities occur west of the Sierra Nevada and northwest of Baja California extending through the coastal regions of Oregon (California Polytechnic State University 2010). Within the Conservation Area, coastal scrub communities exist on hilltop openings, primarily on south facing slopes. Elevations range from sea level to about 1800 feet. Latitude, soil substrate and proximity to the ocean influence the 
species' composition and growth patterns of these coast scrub communities. This plant community typically exists on shallow soils with poor nutrient content and sparse water availability. Vegetation in this plant community have shallow roots and can be deciduous in the summer when there is minimal or no water available. Growth generally occurs when water is more prevalent, primarily during the winter. Coastal scrub community in this region most closely follows the description by Holland (1986) and the California sagebrush type as described by Sawyer and Keeler-Wolf (1995) according to the Santa Margarita Ranch Agricultural Cluster Residential Subdivision Environmental Impact Report (Rincon, Inc 2008). The dominant species of this plant community in the region is California Sagebrush (Artemisia californica). Other common species in the Central Coast Scrub can be found in Table 3.7.

\begin{tabular}{|l|l|}
\hline \multicolumn{2}{|c|}{ Common Central (Lucian) Coast Scrub Species within the Conservation Area } \\
\hline $\begin{array}{l}\text { holly-leaved navarretia } \\
\text { (Navarretia atractyloides) }\end{array}$ & coyote bush (Baccharis pilularis) \\
\hline bush monkey-flower (Mimulus aurantiacus) & coffeeberry (Rhamnus californica) \\
\hline sages(Salvia sp.) & poison Oak (Toxicodendron diversilobum) \\
\hline deerweed (Lotus scoparius), & rock rose (Helianthemum scoparium), \\
\hline lilac mariposa lily (Calochortus splendens), & California peony (Paeonia californica) \\
\hline
\end{tabular}

Source: Holland and Keil (1995) and Rincon Inc. (2008)

Table 3.7 Common Central (Lucian) Coast Scrub Species

The Central Coastal Scrub community is a mix of northern and southern California Coastal Scrub species. Northern species tend to be strictly on the western side of the Coastal Range. This is different from Southern Coastal Scrub that can be found in interior valleys and on the foothills of the coast range. According to the Santa Margarita Ranch Agricultural Residential Cluster Subdivision Environmental Impact Report, there are less than twenty-one acres of Central Coastal Scrub found on the 
3,700-acre project site for their proposed project development. It is suspected that the existence and number of acres of Central coastal scrub within the Conservation Area are limited by the type of coastal scrub species (northern and southern coastal scrub) and their ability to persist in the drier rain shadow east of the Santa Lucia Range. Central (Lucian) coastal scrub is considered to be of high habitat quality due to their relatively undisturbed nature and connectivity with several other native habitat types extending beyond the Conservation Area (Rincon Inc. 2008).

\subsubsection{Mesomorphic Herbaceous Vegetation}

The National Vegetation Classification Hierarchy defines Mesomorphic Herbaceous Vegetation as a vegetation community of upland forb-like and grassland vegetation that dominate the ground layer consisting of at least ten percent cover. Ten percent of the Mesomorphic Herbaceous Vegetation communities can contain woody tree or plant species. Some areas classified as herbaceous may contain ten percent or

more of shrub/scrub species due to the difficulty in distinguishing herbaceous and scrub growth in post disturbance areas (Aerial Information Systems 2009). The primary herbaceous vegetation or rangeland are important working landscapes and provide essential habitat and other ecological functions. According to the County of San Luis Obispo Agriculture Element, the northern predominantly open hillsides of the Santa Lucia Range are the best for grazing in the County whereas other, drier and more tree and brush covered rangeland are usually of poorer quality (County of San Luis Obispo Agriculture Element 2010). Both annual and perennial grasslands are prevalent within the Conservation Area. Grassland communities make up approximately fifteen percent of the total land area within the Conservation Area. Common perennial grassland species can be found in Table 3.8. Common annual grass species are listed in Table 3.9. 


\begin{tabular}{|l|l|}
\hline \multicolumn{2}{|c|}{ Common Perennial Grassland Species } \\
\hline purple needlegrass (Nassella pulchra) & Deergrass (Muhlenbergia rigens) \\
\hline Sandberg's bluegrass (Poa secunda) & California oatgrass (Danthonia californica) \\
\hline
\end{tabular}

Table 3.8 Common perennial grassland species

\begin{tabular}{|l|l|}
\hline \multicolumn{2}{|c|}{ Common Annual Grassland Species } \\
\hline soft chess (Bromus hordeaceus) & $\begin{array}{l}\text { tocalote/spotted knapweed (Centaurea } \\
\text { melitensis) }\end{array}$ \\
\hline ripgut grass (Bromus diandrus) & Paso Robles navarretia (Navarretia jaredii) \\
\hline slender wild oats (Avena barbata) & Jolon brodiaea (Brodiaea jolonesis) \\
\hline italian ryegrass (Lolium multiflorum) & California milkweed (Asclepias californica) \\
\hline rat-tail fescue (Vulpia myuros) & turkey mullein (Eremocarpus setigerus) \\
\hline red-stem filaree (Erodium cicutarium) & California poppy (Eschscholzia californica) \\
\hline yarrow (Achillea millefolium) & $\begin{array}{l}\text { hayfield tarweed (Hemizonia Deinandra } \\
\text { congesta ssp. luzulifolia) }\end{array}$ \\
\hline italian thistle (Carduus pycnocephalus) & \\
\hline
\end{tabular}

Source: Rincon Inc. 2008

*Bold species are common invasive/noxious weeds.

Table 3.9 Common annual grassland species

Development, agriculture, noxious weed invasion or purposeful planting of exotic species has altered ninety-nine percent of California's grasslands (Cheadle Center for Biodiversity and Ecological Restoration 2011). Most of the grassland landscape within the Conservation Area has been altered or disturbed in some way. Non-native grasses were introduced to provide feed for cattle during early Spanish colonization. Over time, many of the non-native grasses have out competed native grassland species. Common non-native species in the region are slender wild oats(Avena barbata), rip-gut brome (Bromus diandrus), soft chess brome (Bromus hordeaceus), and annual ryegrass (Lolium multiflorum) (Holland and Keil 1995). Much of the grassland exists on old river terraces just south and east of Santa Margarita Reservoir and to a greater extent, north 
and west of the Reservoir. Most grassland is located on private property and is prevalent on all the large properties in the floodplain and Salinas River terrace within the Conservation Area. Many of these grassland communities are utilized for ranching operations and dryland farming. See Figure A.15 in Appendix A for a map of herbaceous plant communities within the Conservation Area. Grassland often coexists with intermittent tree communities in this region. Oak savannah woodlands were once a common vegetation community in California. They have and continue to be the one of the fastest developed vegetation communities in the state (California Rangeland Trust 2010).

\subsubsection{Temperate Flooded Riparian Vegetation}

The National Vegetation Classification Hierarchy defines Temperate Flooded Riparian Vegetation as woodland and shrubby riparian areas with at least eight to ten percent cover. Either trees or shrubs can dominate or co-dominate the site. There are approximately 2,162 acres of temperate flooded riparian vegetation or 1.55 percent of the total land area within the Conservation Area. These areas follow headwaters, tributaries and the mainstem of the Salinas River itself. Figure A.9 in Appendix A is a map of riparian vegetation along drainages throughout the Conservation Area.

Riparian areas are plant communities that border waterways such as lakes, wetlands, ponds, streams and rivers. In this vegetation community, trees or shrubs can dominate or co-dominate in various succession stages (Aerial Information Systems 2009). These areas can be seasonally or temporarily flooded primarily in months with higher precipitation. Valley or coast live oak can make up part of a riparian vegetation community but they do not dominate riparian canopies. Riparian scrub communities consist of various willow species that grow dense thickets on river and 
streamside banks. Common central coast riparian scrub and woodland, and herbaceous species are listed in Table 3.10. Table 3.10 shows riparian vegetation documented at the Regional Water Quality Control Board water quality assessment sites. Two of these sites are within the Conservation Area, but it is assumed that similar vegetation occurs in other riparian corridors throughout the watershed. An Environmental Impact Report for the Santa Margarita Ranch Agricultural Residential Cluster Subdivision (Rincon, Inc. 2008) states that there are several unnamed drainages located throughout the region, some of which have established riparian vegetation.

Riparian vegetation within the Upper Salinas Watershed plays a pivotal role in several ecosystem functions (LT-US RCD 2004). It provides essential bank and rill erosion control and water quality functions. Studies have shown that riparian vegetation can significantly reduce, not only sedimentation in-stream, but also reduce the presence of chemical and biological pollutants in streams (Lee et al.. 2003 and Dosskey et al.. 2002). In addition, riparian vegetation manages stream flow and ground water absorption (Bellows 2003). Riparian vegetation also provides quality habitat for many wildlife species. Plant and vegetation debris provide adequate food and shelter for predators and prey species as well as help to create riffle and pool habitat for fish species. Riparian vegetation also helps to regulate water temperature, which has a direct effect on dissolved oxygen levels in-stream. Fish and macro invertebrates thrive in particular DO ranges and riparian vegetation helps to regulate those ranges by managing in stream temperatures (Wesche et al. 1987). 


\begin{tabular}{|l|l|}
\hline \multicolumn{2}{|c|}{ Common Riparian Species Found in the Conservation Area } \\
\hline \multicolumn{2}{|c|}{ Trees } \\
\hline Common Name & Scientific Name \\
\hline blue oak & Quercus douglasii \\
\hline coast live oak & Quercus agrifolia \\
\hline elderberry & Sambucus mexicana \\
\hline Fremont cottonwood & Populus fremontii \\
\hline black cottonwood & Population balsamifera \\
\hline sycamore & Platanus racemosa \\
\hline valley oak & Quercus lobata \\
\hline Arroyo willow & Salix lasiolepis \\
\hline red willow & Salix laevigata \\
\hline California foothill pine & Pinus sabiniana \\
\hline box elder & Acer negundo \\
\hline & Scientific Name \\
\hline Common Name & Atriplex lentiformis brewerii \\
\hline Brewers saltbrush & lupinus spp. \\
\hline bush lupine & Eriogonum fascicumlatum \\
\hline California buckwheat & Rosa californica \\
\hline California wild rose & Heteromeles arbutifolia \\
\hline christmas berry & Baccharis pilularis \\
\hline coyote brush & Juniperus spp. \\
\hline juniper & Baccharis viminea \\
\hline mule fat & Atriplex lentiformis brewerii \\
\hline quail bush & Rubus ursinus \\
\hline California blackberry & Urtica dioca ssp. Holosericea \\
\hline stinging nettle &
\end{tabular}




\begin{tabular}{|l|l|}
\hline \multicolumn{2}{|c|}{ Aquatic Plants } \\
\hline Common Name & Scientific Name \\
\hline aquatic algea & Cladophora spp. \\
\hline aquatic grass & Zanichellia spp. \\
\hline coontail & Ceratophyllum demersum \\
\hline elodea & Elodea canadensis \\
\hline mosquitofern & Azolla spp. \\
\hline myriophyllum & Myriophyllum aquatium \\
\hline
\end{tabular}

Source: Holland and Keil 1995, Rincon Inc 2008, RWQCB 2007

Table 3.10 Common riparian species in the Conservation Area

The majority of riparian habitat is characterized by several species of mixed hardwoods in the canopy, and a number of shrub and herbaceous species in the understory. These species vary depending on topography and aspect. Riparian areas seem to have a mixed woodland canopy and a mixed shrub and herbaceous understory. As elevation increases, riparian woodland and shrub communities tend to dominate. Due to land disturbances from agricultural based land uses, riparian buffers within the Conservation Area are sometimes very narrow or virtually nonexistent.

Loss of riparian vegetation in the Upper Salinas Watershed has increased since 1900 and is attributed to urban development and intensified agricultural land uses (LTUS RCD 2004). Intensified land use such as municipal water use has increased in both Atascadero and Paso Robles, which depletes ground water supplies and reduced spring flows. Impervious surfaces also have contributed to increase runoff and overland flow which causes further stream bank erosion and loss of critical riparian habitat (Upper Salinas-Las Tablas Resource Conservation District 2004).

\subsubsection{Temperate Meadow and Vegetated Wetland/Marsh Areas}

Temperate meadows are temporary and/or seasonally flooded vegetation communities containing flora such as sedges and rushes. Marsh settings are 
permanently flooded areas dominated by cattails and bulrushes. Vegetation stands in these plant communities are generally less than five acres in size. Within the Conservation Area, these communities primarily exist north of Santa Margarita Reservoir and west of the Salinas River. There are approximately 168.5 acres or 0.12 percent of the total land area within the Conservation Area. There are several "seasonal pool" wetlands, and unnamed drainages located on Property Ten (Rincon Inc 2008). It is assumed that there are areas with similar hydrologic and vegetative characteristics throughout the Conservation Area. These sites are generally small, equating to less than ten acres in size. See Figure A.9 in Appendix A for a map of temperate meadow and vegetated marsh areas within the Conservation Area.

\subsubsection{Wetlands Associated with Naturally Sparse or Un-vegetated Areas}

Wetlands containing naturally sparse or un-vegetated areas are defined as having plant canopies in all vegetation layers as being under eight to ten percent and generally less than five acres in size (Aerial Information Systems 2009). Some examples of these areas include:

- Riverine and Lacustrine Flats

- Rock Outcroppings

- Sand

- Interior Cliffs

According to the GIS data from the County of San Luis Obispo (2009), the Conservation Area contains several of these wetland types. There are approximately 118 acres of the vegetation community type, which is equivalent to 0.08 percent of the total land area within the Conservation Area. See Figure A.9 in Appendix A for a map of 
wetlands associated with naturally sparse or un-vegetated areas within the Conservation Area.

\subsection{Special Status Plant Species}

In addition to the diversity of plant communities listed above, there are several "special status" plant species found in the watershed. "Special status" species are considered by California Fish and Game to be taxa of the greatest conservation need and fit into one or more of the following categories:

- Officially listed or proposed for listing under the State and/or Federal Endangered Species Acts.

- State or Federal candidate for possible listing.

- Taxa which meet the criteria for listing, even if not currently included on any list, as described in Section 15380 of the California Environmental Quality Act Guidelines.

- Taxa considered by the Department to be a Species of Special Concern (SSC).

- Taxa that are biologically rare, very restricted in distribution, declining throughout their range, or have a critical, vulnerable stage in their life cycle that warrants monitoring.

- Populations in California that may be on the periphery of a taxon's range, but are threatened with extirpation in California.

- Taxa closely associated with a habitat that is declining in California at an alarming rate (e.g., wetlands, riparian, old growth forests, desert aquatic systems, native grasslands, vernal pools, etc.).

- Taxa designated as a special status, sensitive, or declining species by other state or federal agencies, or non-governmental organization (NGO). 
"Special status" species were identified using Fish and Game's California Natural Diversity Data Base and the California Native Plant Society's Inventory of Rare and Endangered Plants online database. According to the California Natural Diversity Database (CNDDB) and the Santa Margarita Agricultural Residential Cluster Subdivision Environmental Impact Report (Rincon Inc. 2008), there are forty-one "special status plant species". The list from both the CNDDB and the Agricultural Residential Cluster Subdivision EIR (Rincon Inc. 2008) can be found in Table B.3 in Appendix B. A more localized query of the quadrants with which the Conservation Area is in, found a total of thirty-six plant species, of which one is listed as endangered on both the federal and state endangered species list. The California Natural Diversity Database and the EIR (Rincon Inc 2008) are not a comprehensive list of species. Further studies are needed to understand the spatial presence of "special status species".

\subsection{Non-native Invasive Plant Species}

In 2006, the California Invasive Plant Council updated its inventory of statewide non-native invasive plants that threaten state wildlands. The Invasive Plant Council set the following criteria to define these species. Non-native invasive plants are species that:

- Are not native but are able to spread into wildland ecosystems.

- Displace native species, hybridize with native species, alter biological communities, or alter ecosystem processes.

- Are significant in that they change natural communities by altering habitat and impacting food sources for sensitive animal species.

A list of non-native invasive plant species was produced from the California Invasive Plant Council online database (http://www.cal-ipc.org/ip/inventory/weedlist.php) and is located in Table B.2 in Appendix B. The Conservation Area is part of the Central 
Western Floristic Province, from which the species list was derived. Within this province, there are 204 non-native invasive plant species. The Province covers a much larger area beyond the Conservation Area; therefore it is possible that not all of these plants are found within the Conservation Area to the degree indicated by the database or at all. Thirty-eight of those species are labeled "Evaluated But Not Listed." This means that sufficient data does not exist to determine the invasive status of the species or the species currently does not pose a significant impact in the region. Sixty-one species were labeled "High" or "Alert," meaning they have high potential to invade new ecosystems. The California Central agrees in order to get a more to scale list of invasive species, further research must be completed.

\subsection{Wildlife}

The Conservation Area is home to a diverse number of wildlife species due to its variety of available habitats. Ninety-five percent of the State's threatened and endangered species can be found on private rangelands like the rangelands within the Conservation Area (California Rangeland Trust 2010). South Coast Wildlands (2010) performed an analysis of lands with important habitat linkage quality and lists lands in and around the Conservation Area as "high priority habitat linkages". See Figure 3.2 below for a visual representation of that analysis. A list of special status wildlife species found on the Santa Margarita Ranch was compiled in the Santa Margarita Ranch Agricultural Residential Cluster Subdivision Environmental Impact Report (Rincon Inc 2008). That list can be found in Table C.2 in Appendix C. Three species whose habitat conditions can be found within the Conservation Area are listed as both state and federally threatened/endangered species include: the vernal pool fairy shrimp, south/central coast steelhead, California tiger salamander, and the California red-legged frog (Rincon Inc 2008). Seasonal pools and many of the tributaries of the Salinas River 
offer small segments of suitable habitat for vernal pool fairy shrimp and the California red-legged frog, particularly where tributary floodplains are seasonally flooded by winter and early spring precipitation.

Figure 3.2 South Coast Wildlands Essential Habitat Connectivity Priorities

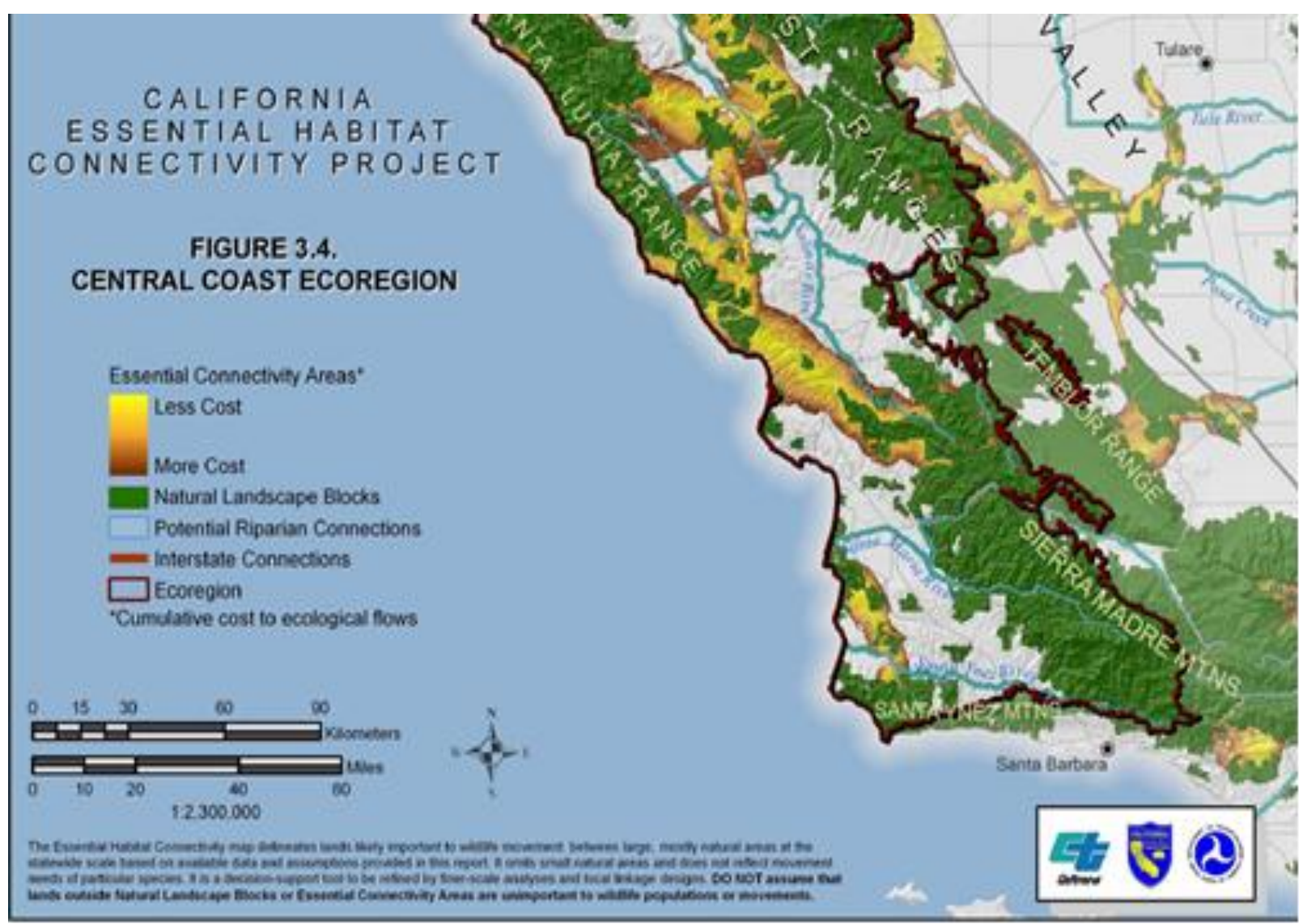

Source: South Coast Wildlands 2010

While no vernal pool fairy shrimp were found during the single wet season survey conducted for the Santa Margarita Ranch Agricultural Residential Cluster Subdivision (Rincon Inc. 2008), the species does exist in northern San Luis Obispo County and in northern Santa Barbara County suggesting possible vernal pool fairy shrimp presence 
within the Conservation Area. Quality habitat for vernal pool fairy shrimp and the other four species of branchiopods can be found within the Conservation Area as indicated by the study of the 3,700 acres project site at Santa Margarita Ranch (Rincon Inc. 2008). It is assumed that the habitat and climate conditions at Santa Margarita Ranch is similar to that of other parts of the Conservation Area and the potential to find vernal pool species increases as the size of available habitat increases.

In addition to the three threatened/endangered species above, there are twentysix other special-status wildlife species that can be found in the region, many of which have localized niches according to the California Natural Diversity Database. A list of species gathered for the Santa Margarita Ranch Agricultural Cluster Subdivision Environmental Impact Report (2008) and the California Natural Diversity Database can be found in Table C.1 in Appendix C. Species and habitat found for the Santa Margarita Ranch Agricultural Cluster Subdivision Environmental Impact Report are assumed to be in similar areas throughout the Conservation Area. However the list from the EIR and the CNDDB is not a comprehensive list of all species' presence or absence throughout the Conservation Area. The Conservation Area's diverse habitats provide critical wildlife corridors moving east to west from the Los Padres National Forest to the Santa Lucia Mountains and from north to south between the mountain ranges. It is assumed that the wildlife species identified in the Santa Margarita Ranch Agricultural Residential Cluster Subdivision Environmental Impact Report can be found throughout the Conservation Area, although the list is not considered exhaustive. The Nature Conservancy has identified the landscape within the Conservation Area as providing significant habitat corridor linkages for many migratory birds, herpetofauna and mammal species. Surveys of the region and a review of the California Natural Diversity Database also list a number of common scrubland species that are highlighted in Table 3.11. Other common species are listed found in a mixture of other habitat types can be found in Table 3.12. 
There are fourteen species of fish that inhabit the tributaries of the Upper Salinas River. One, the southern steelhead trout (Oncorhynchis mykiss), is a state listed species. Some common species include: black crappie (Pomoxis nigromaculatus), western roach (Hesperoleucus symmetricus) and the five speckled dace (Rhinichthys osculus). The construction of the Salinas Dam in 1942, which created Santa Margarita Reservoir, created a significant migratory barrier to fish on the Salinas River and upstream tributaries. Currently, Santa Margarita Creek and Hale Creek, both downstream of the dam, contain small steelhead populations (Upper Salinas-Las Tablas Resource Conservation District 2004, California Department of Fish and Game 2000). Steelhead have historically been found as far upstream of the Salinas River as the National Forest Guard Station prior to the existence of the Santa Margarita Reservoir. In 1999, individual adult steelhead were spotted in Santa Margarita Creek (Upper SalinasLas Tablas Resource Conservation District 2002). According to the Santa Margarita Ranch Agricultural Residential Cluster Subdivision Environmental Impact Report (Rincon Inc 2008) steelhead inventories were conducted below the Salinas Dam on Rinconada and Trout Creek tributaries. Coast steelhead trout were observed in Rinconada Creek, but it is suspected that, while juveniles are able to migrate back to the ocean, they are unable to return to their spawning grounds because of Pierce Dam. Steelhead were definitively observed during an inventory of Trout Creek. Habitat inventories suggest that steelhead may also occur in Tostada Creek on the Santa Margarita Ranch property (Rincon Inc 2008).

The Conservation Area is part of a larger migratory bird region known as the Pacific Flyway, which consists of the pacific states from Alaska to Mexico. Over 455 bird species have been documented in San Luis Obispo County. Many species are known to both migrate and breed in the Conservation Area. Appendix C includes a comprehensive list of birds found throughout the County of San Luis Obispo. Most of 
these species can be found migrating through the Conservation Area and to a lesser extent may stay and nest in the region. Some of the nesting birds are included in Table 3.12.

\begin{tabular}{|l|l|}
\hline \multicolumn{2}{|c|}{ Common Scrubland Wildlife Found in the Region } \\
\hline black bear (Ursus americanus) & mountain lion (Puma concolor) \\
\hline Tule elk (Cervus canadensis nannodes) & bobcat (Felis or Lynx rufus) \\
\hline coyote (Canis latrans) & mule deer (Odocoileus hemionus) \\
\hline bigeared woodrat (Neotoma macrotis) & California mouse (Peromyscus californica) \\
\hline brush rabbit (Sylvilagus bachmani) & deer mouse (Peromyscus maniculatus) \\
\hline \multicolumn{2}{|c|}{ Birds } \\
\hline California thrasher (Toxostoma redivivum) & blue-gray gnatcatcher (Polioptila caerulea) \\
\hline $\begin{array}{l}\text { coast range fence lizard (Sceloporus } \\
\text { occidentalis bocourtii) }\end{array}$ & $\begin{array}{l}\text { California alligator lizard (Elgaria } \\
\text { multicarinata multicarinata) }\end{array}$ \\
\hline $\begin{array}{l}\text { San Diego gopher snake (Pituophis } \\
\text { catenifer annectens) }\end{array}$ & $\begin{array}{l}\text { California king snake (Lampropeltis getula } \\
\text { californiae) }\end{array}$ \\
\hline $\begin{array}{l}\text { Southern Pacific Rattlesnake (Crotalus } \\
\text { viridus helleri) }\end{array}$ & \\
\hline
\end{tabular}

Source: The Nature Conservancy, LT-US RCD 2004 and Rincon Inc. 2008

Table 3.11 Common wildlife species found in Scrubland habitat in the region

\begin{tabular}{|l|l|}
\hline \multicolumn{2}{|c|}{ Other Common Species Found within the Conservation Area } \\
\hline \multicolumn{2}{|c|}{ Mammals } \\
\hline Botta's pocket gopher (Thomomys bottae) & American badger (Taxidea taxus) \\
\hline $\begin{array}{l}\text { California ground squirrel (Spermophilus } \\
\text { beecheyi) }\end{array}$ & \\
\hline \multicolumn{2}{|c|}{ Birds } \\
\hline
\end{tabular}




\begin{tabular}{|l|l|}
\hline golden eagle (Aquila chrysaetos) & red-tailed hawk (Buteo jamaicensis) \\
\hline American kestrel (Falco sparverius) & western kingbird (Tyrannus verticalis) \\
\hline western meadowlark (Sturnella neglecta) & lark sparrow (Chondestes grammacus) \\
\hline yellow-billed magpie (Pica nuttalli) & black phoebe (Sayornis nigricans) \\
\hline $\begin{array}{l}\text { Brewer's blackbird (Euphagus } \\
\text { cyanocephalus) }\end{array}$ & American goldfinch (Carduelis tristis) \\
\hline Bewicks wren (Thryomanes bewikii) & \\
\hline
\end{tabular}

\begin{tabular}{|l|l|}
\hline \multicolumn{2}{|c|}{ Reptiles } \\
\hline $\begin{array}{l}\text { Pacific Ring-Necked Snake (Diadophis } \\
\text { punctatus ssp. vandenburghi) }\end{array}$ & $\begin{array}{l}\text { Coast Gartersnake (Thamnophis elegans } \\
\text { ssp. terrestris) }\end{array}$ \\
\hline $\begin{array}{l}\text { Southwestern Pond Turtle (Actinemys } \\
\text { marmorata pallida) }\end{array}$ & Amphibians \\
\hline \multicolumn{2}{|c|}{} \\
\hline $\begin{array}{l}\text { Bullfrog (Rana catesbeiana) } \\
\text { California Red-legged Frog (Rana aurora } \\
\text { microscalphus californicus), }\end{array}$ & $\begin{array}{l}\text { Pacific Chorus Treefrog (PseudacrisHyla } \\
\text { regilla) }\end{array}$ \\
\hline $\begin{array}{l}\text { California (western) Toad (Bufo boreas } \\
\text { halophilus) }\end{array}$ & Coast Range Newt (Taricha torosa torosa). \\
\hline
\end{tabular}

Source: The Nature Conservancy, Rincon Inc. 2008, and Upper Salinas-Las Tablas Resource Conservation District 2004

Table 3.12 Common grassland species found in the region

\subsection{Land use}

As mentioned earlier there are several types of land uses within the Conservation Area. Agriculture, focused on cattle ranching and vineyards are the primary land uses. Agriculture makes up approximately twenty percent of the land area and exists mostly in the flood plain and Salinas River terrace. Hay is also a common dryland crop in the region. Many of the ranchers in the region rely on multiple agricultural uses to supplement their ranching operation. Some of these ranches are family owned and 
operated and some are owned by the landowner and managed by other entities. There are niche cattle markets located within the area, producing organic grass-fed beef, vineyards and proposed developments such as the agriculture cluster subdivisions on Santa Margarita Ranch.

There has been a surge in the popularity of vineyard development within the last thirty years. As beef markets make it difficult for ranchers to maintain their ranching operation, many look to other types of land uses to supplement their operation. Vineyards and hay pastures are fairly common within the Conservation Area. These land uses are permitted according to the County of San Luis Obispo General Plan and subsequent zoning ordinances. About fifty-eight percent of the land area within the Conservation Area consists of open space, which is primarily made up of the Los Padres National Forest and the Santa Margarita Reservoir.

Figure A.10 in Appendix A shows the County of San Luis Obispo's designated land uses per parcel of land within the Conservation Area. Table 3.13 shows the acres associated with each of the designated land uses and associated percentage relative to the land area within the Conservation Area. Of the land use designations, open space, agriculture and rural lands make up fifty-seven percent, twenty percent and fifteen percent of the landscape respectively. These three land designations make up over ninety percent of the land use within the Conservation Area. Rural Land and Agricultural Land have similar designations. Agricultural Land allows for commercial agriculture whereas Rural Land does not. Non-commercial agriculture can exist on Rural Lands where soil and water are appropriate.

\begin{tabular}{|lrr|}
\hline Land Use & Acres & \multicolumn{1}{c|}{$\%$} \\
Coverage
\end{tabular}




\begin{tabular}{|lrr|}
\hline Open Space & 182660.5 & $57.80 \%$ \\
\hline Commercial Retail & 18.53 & $0.01 \%$ \\
\hline Commercial Service & 6.14 & $0.00 \%$ \\
\hline City & 16794.91 & $5.31 \%$ \\
\hline Industrial & 17.55 & $0.01 \%$ \\
\hline Public Facilities & 35.69 & $0.01 \%$ \\
\hline Recreation & 677.55 & $0.21 \%$ \\
\hline Rural Lands & 49067.05 & $15.53 \%$ \\
\hline Residential Multi- & 5.45 & $0.00 \%$ \\
\hline Family & & \\
\hline Rural Residential & 1118.7 & $0.35 \%$ \\
\hline Residential Suburban & 2512.9 & $0.80 \%$ \\
\hline & & \\
\hline Residential Single & 84.14 & $0.03 \%$ \\
\hline Family & & \\
\hline Total Acreage & 316041.6 & $100.00 \%$ \\
\hline Table 3.13 Land use & & \\
\hline
\end{tabular}

Table 3.13 Land use designations within the Conservation Area

\subsubsection{Protected Land}

Another important consideration is the project land's spatial relationship to existing protected areas i.e. public land and protected private land. Within the Conservation Area, there are three main types of protected lands: public land, easement lands and Williamson Act lands. Public land is a more permanent protection, whereas the Williamson Act, now under the threat of being defunded through the California Legislature, traditionally gave property tax relief to private landowners who have valuable open space or agriculture operations on their property. In total, public land makes up about 75,300 acres and the Williamson Act protects approximately 
34,300 acres. Several conservation easements for lands within the Conservation Area have been proposed and a couple of easement properties currently exist.

\section{Public Land}

Property under the jurisdiction of Los Padres National Forest provides important contiguous habitat of protected land. Contiguous landscapes provide important large habitat and ecosystem features. Private property adjacent to public land should be considered as a potential conservation project, especially properties identified as having important ecosystem and habitat features. Figure A.11 in Appendix A shows the relationship of the largest privately owned properties to public land parcels.

The United States Forest Service primarily holds federal lands within and surrounding the Conservation Area. Federal land within the Conservation Area encompasses approximately 73,000 acres equaling almost fifty-three percent of the land area within the Conservation Area. State owned lands within the Conservation Area include 1,830 acres equaling approximately 1.3 percent of the total land area. The Department of Water Resource manages most of the state owned lands. San Luis Obispo County holds 504 acres equaling almost 0.4 percent of the total land area. The property is located adjacent to Santa Margarita Reservoir, which is designated a recreation area.

In total, there is 75,300 acres or fifty-four percent of the land area protected under governmental jurisdiction. Most of these lands form the two mountain ranges surrounding the privately held lands within the Conservation Area and the lands immediately surrounding Santa Margarita Reservoir. The high percentage of protected lands within the Conservation Area presents an opportunity for the protection of large contiguous tracts of riparian, shrub, and oak savannah grassland habitat connecting both public and private land. 


\section{California Land Conservation Act of 1965 (Williamson Act)}

The Williamson Act was designed to protect farmland and open space from urbanization. Local governments can enter into contracts with landowners that restrict particular parcels to certain uses i.e. farming and open space. In return, landowners receive tax benefits that are lower than the State's Proposition Thirteen property tax rates. Taxes are based on the open space and agricultural use of the property. Property tax assessments of Williamson Act contracted land are based upon generated income as opposed to potential market value of the property. Local governments receive payments from the state in lieu of property taxes lost from entering into a Williamson Act contract with landowners in their jurisdiction (California Department of Conservation 2011). Properties covered under the Williamson Act can be viewed in Figure A.12 in Appendix A. Landowners with contracts save an estimated twenty to seventy-five percent in property taxes each year. Approximately thirty-three percent of farmers and ranchers surveyed in 1989 said that without the act they would no longer own their parcel (Carter et al. 1989).

The County of San Luis Obispo has a procedure for entering into contracts with landowners and can be found at http://www.slocounty.ca.gov/planning/landconservation.htm. In San Luis Obispo County, contracts can be up to twenty years with the exception of lands within a mile of urban reserve line or village reserve line, which can enter into a maximum of ten years (County of San Luis Obispo 2011). Agricultural land and any living improvements such as orchards and vineyards are valued annually based on income generated from those uses. The present value of the land is calculated by determining the potential future income gained from the land uses. Taxable value for non-living improvements (farm worker housing, barns, irrigation systems, pumps, fencing, etc) and residential dwellings 
are based on when the improvements are completed or when the property was originally acquired. They are valued based on Proposition Thirteen rates, which is the fair market or base value at the time the property changes ownership. The base value can then increase up to a maximum of two percent per year. These two values are combined to determine the overall property value from which the property tax is based (County of San Luis Obispo 2003). Appendix D shows an example of the difference between how properties are valued under Proposition Thirteen and restricted land value.

Williamson Act contracts have been debated whether they provide meaningful long-term conservation. While it clearly helps landowners every year by providing some tax relief, contracts are temporary and many conservation advocates want more permanence in public funds being spent for conservation. As of March 2010, the State of California has cut ten million dollars from Williamson Act funding. The state has also not been meeting its subvention obligations to counties, leaving the act in jeopardy. Without state funding, many counties will not be able to maintain Williamson Act contracts. The San Luis Obispo County Board of Supervisors stated in June 2011 that contracts would be upheld. The Board of Supervisors also stated that they would be reviewing County agricultural tax break policy in the future to possibly make adjustments to the criteria for property to be considered Williamson Act lands. Most of the operating cattle ranches in the Conservation Area rely on property tax breaks from the Williamson Act, but the future of the Williamson act is still in jeopardy. Ultimately, increased financial pressure from Proposition Thirteen property tax standards may cause some landowners to look to other-more intensive land uses to circumvent further financial pressures. 


\subsubsection{Land Use Planning}

The County of San Luis Obispo has administrative authority to establish a planning and zoning framework within its jurisdiction to accommodate current and future social, economic and environmental needs. Rangeland within the County accounts for a significantly large percentage of privately held land in the County (County of San Luis Obispo General Plan).

The County's rich agricultural history is recognized in many of the County's longterm planning documents. The County of San Luis Obispo has repeatedly expressed the need to protect the agricultural economy, which is important for ranchers considering that cow-calf operations contribute to seven percent of the overall agricultural economy in 2009 (County Department of Agriculture 2010). The Conservation Area is located mostly within the County's Las Pilitas Planning Area. The allowable uses on agriculturally zoned land are essential in understanding constraints and opportunities for conservation endeavors and landowner options to pursue economic endeavors. Much of the private rangeland within the Conservation Area is zoned for agriculture and smaller portions of the area are zoned as Rural Lands.

Agricultural land is defined by the County General Plan as being areas where existing land is used to grow commercial "truck crops, specialty crops, row and field crops, irrigated crops and pasture, irrigated vineyards and orchards, dry farm orchards and vineyards, dry farm and grain, grazing and rangeland"(2010 pg 2-1).

The purpose of the agricultural zoning designation is to protect the agricultural economy within the County and encourage both the open space values and agricultural uses of the land. The County gives high priority to the protection of commercial prime and nonprime agricultural soils where economic viability and landscapes allow for agricultural production. While the County attempts to protect open space and agriculture in the County through zoning ordinances and land use regulations, land conversion from 
rangeland to more intense forms of development is still a threat due to the various permitting processes and allowable uses in the land use zoning code.

Rural Lands are typically areas with large parcel sizes not within urban and village reserve lines that contain open space value. Generally they support home sites for hobby farming and/or ranching and are typically not utilized for commercial agricultural operations. Rural land characteristics generally include:

- Average parcel sizes of nineteen acres or less that are located three miles or more from urban reserve lines.

- Areas outside urban and village reserve boundaries containing land uses such as non-commercial agriculture, mining operations, recreation areas, rural residences and vacation cabins, and watershed, wildlife and open space uses.

- Rural residences are the primary use of the land, but other allowable uses such as agriculture can operate on the land.

- May have soils of poorer quality than in agriculturally zoned areas; vegetation may consist of grasses, woodlands, chaparral and brush.

- Parcel sizes are large enough to allow for at least one building site as well as access to the site.

- May be eligible for Agricultural Preserve status because of their large parcel size under the stipulation that the land meets the criteria of the adopted rules of procedure.

The purpose of the Rural Lands designation is to encourage low-density rural development in order to preserve open space and important ecosystem functions. Another purpose is to maintain comparatively large parcel sizes and low population densities in rural areas outside of the urban and village reserve lines to preserve rural 
character, which includes the preservation of natural landscapes and low development intensity. Table 3.14 illustrates allowable residential densities on both agricultural and rural designated lands.

\begin{tabular}{|llll|}
\hline Land Use & $\begin{array}{l}\text { Subdivision Parcel } \\
\text { Size }\end{array}$ & Building Intensity & Population Density \\
\hline Agriculture & 320 to 20 acres & $\begin{array}{l}160 \text { to } 10 \text { acres per } \\
\text { dwelling }\end{array}$ & $\begin{array}{l}64 \text { to } 4 \text { acres per } \\
\text { person }\end{array}$ \\
\hline $\begin{array}{l}\text { Rural } \\
\text { Lands }\end{array}$ & 320 to 20 acres & $\begin{array}{l}160 \text { to } 10 \text { acres per } \\
\text { dwelling }\end{array}$ & $\begin{array}{l}128 \text { to } 8 \text { acres per } \\
\text { person }\end{array}$ \\
\hline
\end{tabular}

Source: SLO Datafinder 2010

Table 3.14 County of San Luis Obispo Building Intensity per Land Use

The County of San Luis Obispo states in their General Plan and through their Right-to-Farm Ordinance a desire to maintain the regional agricultural and open space characteristics that make the County a unique and agriculturally productive area. Changes or amendments in land use or allowable uses within existing land uses due to anticipated growth, special interest or otherwise can increase economic and growth pressures on agricultural landowners. According to the County of San Luis Obispo's Land Use Element (2009), changes to a land use category i.e. agriculture to single family residential requires a look at the potential development types allowed in the amended land use change and whether the change would "adversely affect the existing or planned appearance of the countryside, community character and style of the development in the surrounding area."(2009 pg 6-7).

\section{Allowable Uses}

The County of San Luis Obispo zones for agriculture and has a particular set of allowable uses. Most of which is used to protect agricultural land from the threat of 
urban development. However, the zoning code permits the conversion from one agricultural use to another. This has led to the increase in more water intensive crops such as vineyards to establish on what was previously rangeland. While feasibility is often limited to weighing the crop-profit potential compared to available natural resources such as water and soil types as well as climate conditions, the County essentially allows for the conversion to more intensified agricultural land use, which in some ways has benefited some ranching families financially. However widespread agricultural shifts to more intensive land uses can have negative impacts on the landscape ecology and hydrological sustainability.

The County of San Luis Obispo's Table 2-2 Allowable Use and Permit Requirements establish the types of uses permitted on agriculturally zoned land. Allowable uses on lands zoned as agriculture are generally allotted flexibility in the types of agriculture managed on the land as well as the construction of small unit developments, i.e. exurban development structures. These allowable uses generally require the landowner go through a permitting/review process. One of the uses permitted on some agricultural and rural zoned lands is the clustering of developments to protect open space.

The County policy for clustering developments on agriculturally zoned land in San Luis Obispo County is called the Agricultural Cluster Subdivision Ordinance (ordinance 22.22.150). This ordinance permits major and minor cluster subdivisions and development on parcels zoned for agriculture. Clustering development theoretically reduces the impact of human influences on the landscape, such as housing, roads, utility infrastructure, etc by clustering the development and reducing the resulting fragmentation of the landscape (Odell, Theobald, and Knight 2003). The basis for cluster development is to minimize environmental and cultural impacts by placing dwelling units close together on a relatively agricultural parcel instead of allowing for 
sprawling development to occur across large intact agricultural parcels. Conditions of approval exist in Land Use Ordinance, Title 22 of the County Code. Parcels eligible for cluster development include Agricultural and Rural Land designated parcels within five miles of a URL or VRL. Minimum size of clustered residential parcels for a Major Agricultural Cluster project and required open space preservation includes the following:

\begin{tabular}{|c|c|c|}
\hline \multicolumn{2}{|c|}{ Clustered Residential Parcel Size } & \\
\hline Minimum & Maximum & Open Space Parcel Minimum Area \\
\hline $\mathbf{1 0 , 0 0 0}$ sq. ft. & 2.5 acres & $95 \%$ \\
\hline
\end{tabular}

Source: Section 22.22.150 San Luis Obispo County Code

While the above stated minimum and maximum clustered residential parcel sizes are the standard, larger parcel sizes may be granted by the Review Authority upon applicant request and based on specific site characteristics.

While clustered development does intensify land uses, the County has mandated open space protection that is managed by an established homeowners association. The County also required a monitoring and assessment to ensure compliance with the mandate.

Lastly, the county prohibits development on NRCS Class I or Class II soils with the exception of agricultural accessory structures with a minor use permit. Soils with this classification are mapped and shown in Figure A.17 in Appendix A. With agricultural cluster development, the homes built on the property can be sold separately. Ultimately, clustered subdivisions can provide an important tool to planning inevitable development projects. However, the impacts of development on ecosystem functions (as water quality, erosion, and wildlife habitat) and local cultural heritage remain an issue.

\section{Annexation and Subdivision}


The Subdivision Map process and the Annexation process can still impose urban development pressures on the landscape. Between 1990 and 1999, urban service areas expanded by 30,000 acres in California. 163,000 of those acres came as a result of annexation (California State Board of Equalization 1995-2000 from Press 2002). For example, as mentioned earlier, the City of Atascadero is planning to annex rangeland to the southwest of the City according to the City of Atascadero's General Plan. Through this process, the City can acquire rangeland from the County and rezone it to meet the needs of the City placing pressures on rangeland owners surrounding the City.

Ultimately, the County's land use planning framework is the primary conservation mechanism within the Conservation Area. However, Liffman et al. (2000 pg 364) state that "land use planning and zoning may reduce rangeland conversion, but are subject to fluid political and economic objectives. They have proven useful for temporarily slowing development until more permanent conservation strategies can be employed, such as conservation easements."

\subsubsection{Threats and Potential Challenges}

In addition to the challenges and potential threats posed by the local planning framework, individual ranching families also face challenges that ranching families have been facing in California for decades. The inability to overcome the regulatory and financial burdens and an increasingly less profitable industry poses a threat to ranching families and their land. Factors that are affecting ranchers include an increasing pressure from urban growth as a result of growing populations, increasingly depressed global and national economic viability for livestock and livestock products, property taxes, and estate and succession planning. Raising cattle and calves is the principal livestock operation in the County (San Luis Obispo County General Plan 2010). Overall, 
there is a shift towards more intensified land uses, which includes an increase in the number of acres under irrigation and an increase in more land use conflicts at the agricultural/urban interface (County of San Luis Obispo General Plan).

Exurban development is also a concern within the Conservation Area. Exurban development is low-density development that occurs outside of incorporated city limits. Exurban residential developments are one of the fastest growing forms of land use and now occupy about twenty-five percent of privately held land in the continental United States (Maestas 2007; Brown et al. 2005; Heimlich and Anderson 2001). Developable lots range from ten to forty acres in size and are currently an allowable land use under the County's zoning code. Some studies suggest that effects on biodiversity on private land may be greatly impacted by exurban development (Hansen et al. 2005). Increasing development on the landscape will make it more difficult to protect native populations of flora and fauna in and around exurban areas due to increasing fragmentation of critical habitat (Maestas 2007). This is because as parcels are subdivided for development, there is an increase in the number of landowners, an increase in land values, which makes developing comprehensive conservation agreements more financially and practically challenging. There are subdivided lots on unincorporated County land to the immediate south of Atascadero within the Conservation Area that demonstrate the effects of exurban development and the difficulty it creates regarding the protection of the landscape. Originally one landowner owned this land. After the subdivision of the land, many landowners now exist, which makes it difficult to develop large-scale land protection programs.

The County Agricultural Cluster Subdivision ordnance is one way the County of San Luis Obispo has attempted to address development in unincorporated areas. Currently, within the Conservation Area, one property has a proposed residential cluster subdivision slated for development. Property Ten has proposed an Agricultural Cluster 
Subdivision development totaling 3,778 acres towards the center of the property, southeast of the town of Santa Margarita. A Future Development Program is also being proposed and contains several proposed development areas throughout the ranch property. Table 3.15 details the proposed cluster residential development and future development on Santa Margarita Ranch. These developments are the largest proposed developments within the Conservation Area. There are several proposed conservation easement areas. Figure E.1 is a map of the proposed area and can be viewed in Appendix E. 


\begin{tabular}{|c|c|}
\hline Project Element & Project Characteristics \\
\hline \multicolumn{2}{|c|}{ Agricultural Residential Cluster Tract 2586} \\
\hline 111 residential clustered lots & 1.0 to 2.5 acres in size (128 acres) \\
\hline \multicolumn{2}{|l|}{1 Dwelling Unit at Headquarters Parcel, Parcel 42} \\
\hline $\begin{array}{l}\text { 40-foot wide private easements (residential) and 30-foot } \\
\text { wide driveway easements }\end{array}$ & 16 acres \\
\hline $\begin{array}{l}\text { 40-foot wide private easements (residential and } \\
\text { agricultural) }\end{array}$ & 19.1 acres \\
\hline Paved roads & 20 and 18 feet wide (or narrow if approved) \\
\hline Water and Septic Utilities & $\begin{array}{l}\text { Water tank, service main and service lines; water wells. } \\
112 \text { on-site septic systems }\end{array}$ \\
\hline Underground and aboveground utilities & $\begin{array}{l}\text { State Water, Salinas Water, Pacific Gas and Electric, } \\
\text { Southern California Gas Company, Phillips Petroleum, } \\
\text { telephone, and cable }\end{array}$ \\
\hline \multicolumn{2}{|c|}{ Future Development Program } \\
\hline $\begin{array}{l}\text { Remainder of the } 550 \text { residential units allowable under the } \\
\text { Salinas River Area Plan (minus } 36 \text { residential units in } \\
\text { Tract 1, and } 112 \text { units on Tract } 2586 \text { ) }\end{array}$ & $\begin{array}{l}402 \text { residential lots, approximately } 400 \text { acres (includes } 50 \\
\text { affordable workforce units) }\end{array}$ \\
\hline Private golf course, club house, shop & 27 to 36 holes / 220 to 280 acres \\
\hline Guest ranch, lodge, and restaurant & 150 to 250 units, 40 tables/200 patrons, 100 acres \\
\hline Restaurant & 40 tables/ 200 patrons \\
\hline Bed and breakfast & 12 rooms \\
\hline Café & 20 tables/ 100 patrons \\
\hline Amphitheater & 200 to 600 seats \\
\hline Craft studios, galleries, and shops & 6,000 square feet \\
\hline Interpretive center and gift shops & 3,000 square feet \\
\hline Nine wineries, tasting rooms, and special events & $\begin{array}{l}8 \text { @ 20,000 to } 40,000 \text { square feet each, } 1 \text { @ } 80,000 \\
\text { square feet / } 42 \text { events per year per facility: six events } \\
\text { with } 1,000 \text { people; six events with } 500 \text { people; six events } \\
\text { with } 300 \text { people; ten events with } 200 \text { people, and; } \\
\text { fourteen events with } 100 \text { people }\end{array}$ \\
\hline Five ranch/farm headquarters & 2.5 acres each \\
\hline Livestock sales yard and café & $\begin{array}{l}20 \text { acres / one Saturday per month with } 80 \text { to } 100 \text { people I } \\
75 \text { patrons }\end{array}$ \\
\hline Horse ranch & $30(+)$ horses \\
\hline Three places of worship & 2,000 to 5,000 square feet each \\
\hline 40 Year Williamson Act parcels (various agricultural uses) & 3,600 acres \\
\hline Oakenshaw Retreat Center & 16 to 24 units on 30 acres with lodge and residence \\
\hline Neighborhood parkland and swimming pool & 5 acres east of Santa Margarita Community \\
\hline Dedication of land for future Sewage Treatment Plant & Location to be determined: 10 acres \\
\hline Dedication of land for expansion of cemetery & 5 acres \\
\hline Public Hiking / Equestrian Trails & $\begin{array}{l}\text { Various locations to be determined upon future non- } \\
\text { agricultural development }\end{array}$ \\
\hline Drainage Facilities & $\begin{array}{l}\text { Various Locations, with a community drainage basin } \\
\text { upstream of the Community of Santa Margarita }\end{array}$ \\
\hline
\end{tabular}

Source: Santa Margarita Ranch Agricultural Cluster Subdivision Environmental Impact Report 2008

Table 3.15 Summary of the proposed Agricultural Cluster and Future Development Program at Santa Margarita Ranch. 
Another project, in its early stages, is the annexation and development on Property Sixteen. A Specific Plan is being developed for the area in anticipation of being annexed by the City of Atascadero. According to www.theeagleranch.com (2008), future plans include a number of different housing types, light commercial areas, parks, open spaces, hotels, an equestrian center and protected landscapes through conservation easements.

Owning and operating a ranch in San Luis Obispo County is increasingly difficult as many of the smaller cities are looking to expand in order to accommodate expected growth (California Rangeland Trust 2010). Local municipalities see open rangeland as an opportunity to make room for future population growth. In 2005 , the County population was 261,572 (California Department of Finance 2011). It is projected that by 2035, the population will grow to 335,082 (California Department of Finance 2011). According to the City of Atascadero's General Plan (2002 update), projected growth in the City will be 36,000 by 2025 . The General Plan outlines the City's interest in expanding south by annexing some of the rangeland on Property Sixteen. Growth pressure on these areas is caused by of a number of factors, but primarily is due to a dramatic increase in land value, farming inefficiency and a loss in ranching as a culture. While the owners of Property Sixteen come from a family with a ranching background, they do not manage or operate cattle on the property. Instead, others manage the cattle operations on the property.

In a survey and analysis conducted by Liffman et al. (2000) of ranching communities in Contra Costa and Tehama Counties, ranchers were affected by their responses to urbanization pressures. More than half of the Contra Costa County ranching respondents stated that it would be desirable to sell off land for the creation of residential development while one-third stated that it did not matter what type of land use change occurred on their land. On the other hand, more than two-thirds of the Tehama 
County ranching participants stated that land use changes to more urbanized development would be undesirable. It can be discerned that increased growth pressures in Contra Costa County have, to some degree, influenced rangeland owners and operators in their land use decisions compared to the lesser growth pressure on Tehama County ranchers who did not want to see their land turned into that type of development (Liffman et al.. 2000). What does this mean for San Luis Obispo County and the Conservation Area? General trends suggest that the factors that affected Tehama and Contra Costa County ranchers would also affect ranchers in similar ways in other areas, including San Luis Obispo County.

Development threats, along with other economic challenges, puts pressure on landowners to subdivide and/or sell their land, particularly property near city limits where as property values increase as a result of proximity and inherent growth pressure (Liffman et al.. 2000). The pressure to sell land for development is compounded by the fact that land affordability makes it difficult for many ranchers to maintain their operation and land. Facing eminent development pressure, landowners may choose to subdivide all or portions of their land to sell to developers.

Pressures of urban sprawl and leap frog development, at least in California, has been slowed to some degree due to better planning practices and the implementation of various growth management-conservation practices (Press 2002). Yet, as the Atascadero General Plan (2002) indicates, eminent pressure still exists from the desire and necessity for urban areas to grow in order to accommodate expanding urban populations. The County of San Luis Obispo's population in 2010 was 269,637 (U.S. Census Bureau 2011) and is projected to increase to 290,312 in 2020 according to the California Department of Finance Interim Population Projections (2011). Much of the growth will occur around the urban cores such as the City of Atascadero. 
Urban areas throughout the County will need to accommodate this growth and provide housing, service and the employment opportunities to support the expanding population. Well planned cities (i.e. more compact growth) can limit the amount of rangeland needed for annexation, but the inherent growth pressures that rancher/landowners face is an issue that many agencies and organizations are trying to address by utilizing a number of conservation tools.

Another potential threat is the increase in intensive agricultural land uses. Conversion of rangeland to vineyards has become a way that ranching families and corporate landowners have found to increase the profitability of their land. This results in a larger impact on water resources and reduces available open space that once made up the rangeland area. Row crops such as vineyards change the vegetation, drainage, wildlife, and soil characteristics of the landscape. Row crop agriculture is considered to have a larger impact on ecosystem functions than well-managed rangeland. Figure A.14 in Appendix A shows areas of urban, exurban and agricultural development within the Conservation Area.

\subsubsection{Economic Viability}

Family ranching operations locally and throughout the state of California are facing increasing economic challenges with regard to maintaining their livestock business. Traditionally, ranchers had smaller herds, but the herds were still economically viable. Fluctuating beef markets, inflation and increased cost inputs have significantly reduced the margin of profit for many family ranchers (Hendrick 2007). According to Hargrave (1993), modern family ranching is generally not a viable option considering investment costs. Butler (2002) states that the average family ranch operating in western states needs more than 300 birthing cows and investments totaling over 1 million dollars to be viable. Butler goes on to state that the average family 
rancher can expect about two percent in returns totaling about $\$ 20,000$. A hypothetical example of a ranching operation's financial inputs and returns can be viewed in Appendix F.

A significant portion of the landholdings is considered an investment for continued rising land values (Hargrave 1993). Hargrave (1993) considers this one of the only economic justification for ranching. The reality is that local working rangelands are susceptible to conversion to urban and rural development resulting from the high costs of maintaining the operation and disparity in earned income (California Department of Forestry and Fire Protection 2010). Torell et al. (2001) stated that livestock production has historically received marginal profits compared to other industries. The nature of the ranching business forces ranchers to take on additional production costs and cannot pass on the prices differences to consumers. This is because commodity prices for beef and other livestock products are set nationally or globally, while input prices are a function of local parameters (California Rangeland Trust 2010).

In 2005, County cow-calf operations contributed $\$ 50$ million in revenue. In 2007 , the industry was valued at $\$ 55.3$ million. This equates to a 10.4 percent decrease in revenue generated from cow and calf operations from 2007. This decrease accounts for annual market fluctuations (supply and demand), but outlines economic fluctuations that make the family operated ranching industry difficult to turn a profit considering land and operation management decisions as well as other financial obligations such as payment of property tax.

The local scale market fluctuations are a result of weather and climate patterns while cattle prices are reflective of a global and national market. Variable market prices that have not kept up with the relatively high property tax values in San Luis Obispo County demonstrate the hardships that family ranchers face in making their livestock operation economically viable. Due to local climatic conditions, ranching families must 
establish financial buffers in order to withstand dry weather years or a downtrend in beef markets (Hendrick 2007). As a result, the California Coastal Commission (2001) stated that animal husbandry, including livestock is declining within the coastal zone and making way for other land uses including urbanization and higher intensity agricultural areas that are more profitable. It can be assumed that similar trends are occurring in areas just outside the coastal zone, such as within the Conservation Area.

In an effort to make the land economically viable, the general trend for many landowners in the County is to convert these rangelands and diversify their crop production, often resulting in increased water use (California Coastal Commission 2001). For example, some rancher-landowners will still run a cattle operation, but will convert some of their land into vineyards. This trend of converting to vineyards has partially resulted in the biggest agricultural change in the County over the last 30 years (California Coastal Commission 2001). Vineyards are replacing dryland farming particularly on grazing lands in order to make the land more profitable. These changes in land use are more water and pesticide intensive and also result in landscape alterations, which have been proven to have an effect on ecosystem functions that were previously protected by less intensive rangeland grazing (California Coastal Commission 2001).

\section{Property Tax}

Property values of Agricultural Land in San Luis Obispo are notably higher than many areas in California and the rest of the United States. While ranchers face an uncertain future as to the viability of their land and operation, higher property taxes present yet another challenge as ranchers struggle to meet their financial obligations. The California Rangeland Trust (2010) has identified property tax as being potentially detrimental to the economic sustainability of ranching operations in the County. Tools 
such as conservation easements and the Williamson Act (discussed in Section 3.13.1) can help provide some fiscal relief and reduce the tax burden. Average agricultural property values in San Luis Obispo County in 2007 was $\$ 4,546$ per acre compared to 2002 where average property values were around \$2,676 per acre (U.S. Department of Agriculture 2009). This indicates a dramatic increase in average agricultural property value and subsequent increase in property taxes. Increasing property taxes coupled with a decreasing profit margin of the ranching community in the County further puts financial pressure on ranchers to figure out ways to make their land economically viable. A hypothetical example of the property tax burden resulting from Proposition Thirteen tax rates as well as tax relief under Williamson Act contracts is demonstrated in Appendix D.

\section{Estate Tax}

The federal estate tax is a burden on families owning large tracts of land. The tax burden associated with the federal estate tax is considered to be one of the biggest threats to family ranching operations in California (California Rangeland Conservation Coalition 2010). Estate tax debts can be very expensive and force ranching families to sell or liquidate assets including their property. The California Rangeland Trust (2010) and the California Rangeland Conservation Coalition (2010) both consider the federal estate tax to be a huge burden and reason for the loss of valuable rangeland in California.

Upon the death of the ranch holder, the value of the property is assessed. The State of California does not assess estate at death. However under the federal estate tax, all assets of the former holder is assessed based on fair market value. Assets include life insurance, real estate, financials and other investments. The federal estate tax is considered a "progressive tax" in that its tax rates are subject to increases up to forty-five percent based on the amount of estate in excess of available exemptions. In 
2009 , the exemption rate was $\$ 3.5$ million per person. In 2010 , no federal estate tax was assessed for those that died in 2010. Currently, the applicable exemption rate is at one million dollars per person (Congressional Budget Office 2009). The maximum tax rate was also increased to fifty-five percent.

As a result, when the estate changes hands, the new estate holder is obligated to pay the assessed tax rate. For ranching families wanting to maintain the land and the operation, the ability to pay the potentially high estate tax rate becomes a challenge. Large landowners have a lot of the assessed value tied up in the land. Ranching operations, as mentioned above, are struggling to be economically viable, making it increasingly difficult to meet financial obligations particularly when the ranch is passed on from one generation to the next.

It is important for ranching families that are planning to pass the ranch on to their families to go through the estate planning process to allow flexibility in how the estate tax obligation will be met. Generally, the estate tax must be paid within nine months after the death of the former estate holder. With proper planning, some exemptions and strategies are available to help ranching families overcome these financial challenges such as estate tax deferment.

\subsection{Landowner Interviews}

Three landowners that own property and ranching operations within the Conservation Area were interviewed to understand local needs, challenges, methods of communication, and thoughts on stewardship and criteria for their willingness to work with organizations such as the Conservancy on conservation projects. A big component of whether or not projects work is the ability to establish solid working relationships with landowners. In order to establish relationships, there must be mutual trust and 
understanding from all stakeholders involved. For example unwilling landowners would make it extremely difficult, if not impossible to accomplish essential projects on their property. On the other hand, organizations unwilling to understand landowner needs and work to meet those needs could potentially marginalize landowners and their desire to implement stewardship measures. Appendix $\mathrm{G}$ is an analysis of general national and state rancher goals, challenges and views on stewardship and conservation. Appendix $\mathrm{K}$ is the sample consent form signed by landowners and the Primary Investigator (Interviewer) in order to ensure privacy and confidentiality. Appendix $L$ is a list of the focus questions used to facilitate conversation.

The landowner interviews were to gain some understanding for the potential to establish working partnerships with landowners that would be mutually beneficial and entirely voluntary on the landowner's part. Three ranchers were interviewed. All the ranchers interviewed considered it a responsibility to be good stewards to the land. All of them incorporate management practices with stewardship in mind including: fencing off riparian areas, rotating cattle on and off of particular areas to prevent overgrazing as well as prevent the proliferation of invasive species, utilizing stock ponds and water troughs to keep cattle out of riparian areas. Two were in the process of developing conservation easements for all or part of their land. 


\subsection{Conservation Landscape Evaluation}

In order to devise a strategy for conservation within the Conservation Area, evaluation of the resources, ecosystem attributes and land use characteristics has been completed. In order to make logical choices and target landscapes for conservation, this section contains recommendations based on baseline data in previous sections. These criteria, or tests, are used to identify potential project areas and include:

- Steelhead Habitat

- Hydrology

- Property size

- Connectivity to existing public and private conservation land

- Development potential
- Presence of special status species

- Habitat Diversity

- Oak woodland/hardwood diversity

- Stream corridor

- Quality rangeland and soils

- Erosion potential (not evaluated)

Properties that meet multiple criteria are generally considered to be a priority over properties meeting less of the criteria listed above along with landowner willingness to participate. Ultimately however, it is up to the Conservancy to make the final decision on what projects should be pursued. Projects containing less of the characteristics mentioned above might contain particular qualities that are considered essential. These "essential" projects may be pursued over projects that meet the multiple criteria test. It is ultimately the judgment of the Conservancy staff, Land Committee and Board of Directors to choose conservation projects to pursue. 


\subsection{Steelhead Habitat}

Properties that contain steelhead spawning and rearing habitat are high priorities for conservation. The Salinas River and its tributaries below the Santa Margarita Reservoir are important for salmonid migration and breeding habitat compared to areas above the Salinas Dam. The dam at the head of the Reservoir is a barrier to fish migration. Salmonid individuals have been spotted in some of the major tributaries below the reservoir within the past ten years. While historic steelhead habitat in the Upper Salinas Watershed extended above the Santa Margarita Reservoir, currently, habitat is limited to tributaries below the reservoir due to the Salinas Dam. The dam ultimately serves as a barrier to southern steelhead migration. Figure $\mathrm{H} .1$ Appendix $\mathrm{H}$ is a map of the current and historical steelhead trout in the Upper Salinas Watershed. Currently, Santa Margarita Creek, Trout Creek, Atascadero Creek and its tributary Hale Creek all have documented sightings of steelhead fry and breeding adults.

The confluence of Atascadero Creek and Hale Creek is on Eagle Ranch, just south and west of the City of Atascadero. These areas along with other smaller tributaries of Atascadero Creek were surveyed in May and December of 1999 by the California Department of Fish and Game. A dam exists at the 1.7 mile mark above the confluence on Hale Creek. Many tributaries of Atascadero and Hale Creek have several deep pools (> six feet), riffles, sufficient gravel beds for spawning (with the exception of gravel bed availability above the slide area on monitoring site three). See Figure H.2 in Appendix H for a map of the surveyed area. Seven sites were surveyed during peak flow and base flow seasons (May and December respectively). Good riparian shade and cover also exist along these reaches. Hale Creek flow regime conditions stayed stable for steelhead habitat throughout the year. Santa Margarita residents also reported steelhead presence to DFG in 1999 and inventories that year confirmed the presence of steelhead in Santa Margarita Creek and Trout Creek. As part of the steelhead 
range contraction study, the National Marine Fisheries Service observed several adult migrating steelhead in Santa Margarita Creek in 2003 (NMFS 2005).

Documented areas considered to have had steelhead observations and/or quality steelhead habitat include Atascadero Creek and its tributaries including: Hale Creek, Kathleen Valley and Eagle Creek, Santa Margarita Creek, Trout Creek, Tostada Creek and Rinconada Creek. Kathleen Valley has minimal vegetation cover and primarily has undercut banks as the primary cover. The tributary also contains many cow paths that cross the Creek. Atascadero Creek contains a seventeen-foot high bedrock waterfall approximately 0.3 miles downstream from the Hale Creek confluence that is assumed to be a barrier to trout migration, although according to the California Department of Fish and Game (DFG) residents have stated that the trout still are able to jump over. The Conservancy and its partners should consider ways of smoothing out the stream grade to allow trout an easier passage. Upper and middle sections of Atascadero Creek contain a number of step-runs and step-pools instead of the riffle-pool dynamics characteristic of trout spawning and rearing habitat. Hale Creek below the slide (site three in Figure H.2 in Appendix $H$ ) has several spawning areas i.e. gravel beds. The DFG assessment suggests water quality and sedimentation from a nearby access road may reduce the quality of the spawning habitat (Department of Fish and Game 2000).

Ultimately, further qualitative assessments should be done throughout the Conservation Area below the Salinas Dam to understand the extent of steelhead presence and the quality of available steelhead habitat for at least three or four consecutive years to have a more up-todate understanding of steelhead populations in the region. This should include assessments during both seasonal peak and base flow times of the year to ensure perennial habitat availability for migrating and young fish. Other factors that the California Department of Fish and Game (DFG) report that the decreased probability of survivorship and productivity in these steelhead populations are a result of a lack of flow regimes during fall months and competition and predation of young fish from non-native fish species. As of 1999, staff at Eagle Ranch have 
been rescuing stranded steelhead and placing them in a nearby reservoir. DFG recommends placing fry in perennial sections of Atascadero Creek instead. Control of non-native amphibians and fish species in the reservoir is necessary because they are working their way into the stream systems and are detrimental to steelhead survivorship. It is also suspected that water temperatures in lower Atascadero Creek may exceed trout tolerance levels that prevent successful breeding and rearing (Department of Fish and Game 2000).

\subsection{Other Species with Special Status}

Plant and animal species listed as federally threatened or endangered or a state listed species is a priority characteristic for conservation projects. Properties that contain multiple species are particularly important. California red-legged frog habitat was identified in both the Santa Margarita Ranch Agricultural Cluster Subdivision Environmental Impact Report and the Department of Fish and Game surveys of Atascadero Creek in May and December of 1999 (Rincon Inc 2008 and Department of Fish and Game 2000). The Department of Fish and Game Surveys of Atascadero Creek also yielded California red-legged frog observations. While several listed species were identified as being in the region by the California Natural Biodiversity Database (see Section 3.12) further assessments should be performed to note the extent and specific properties that listed species and their habitat are found on. 


\subsection{Hydrologic Resources}

This plan focuses on a watershed scale planning area. The sensitivity to land use changes on the hydrological resources within the Conservation Area make many areas along the Salinas River and its tributaries important conservation targets. Many of the creeks and streams that are tributaries of the Salinas River and the Salinas River itself flow over private property within the Conservation Area. Many originate in the higher elevations, generally on public land, but the lower foothills, terrace and floodplains exist largely on private land, lending to the importance of private land protection in this area. Protection of the drainage areas is important for downstream water quality and quantity as well as in stream and riparian habitat. Conservation projects with regard to hydrological resources should emphasize areas where major tributaries, named tributaries, and the Salinas River flow over private property. Protecting the headwater tributaries is essential to providing clean and healthy water to the water users of the Santa Margarita Reservoir.

All of the perennial stream channels within the Conservation Area meander across private land at one point or another. Most of these channels flow across one or more of the sixteen largest privately held properties. The only two channels that do not flow across these properties and are largely not protected by public land protections are Pilitas Creek and Alamo Creek. Both of these streams flow on the northeast side of the Salinas River. The confluence of Pilitas Creek occurs on Property Nine. Alamo Creek flows into the Santa Margarita Reservoir on the opposite side of the Salinas Dam. The channels of these streams are found on many smaller properties the Conservancy would probably consider too small for working on long-term conservation agreements unless the area was determined by the Conservancy to be an important priority. Educating landowners on the most appropriate Best Management Practices and sustainable land use management tools may be the best option for these smaller land parcels. 


\subsection{Property Size}

Property size is generally viewed as an important characteristic when setting conservation priorities. As mentioned earlier, private land parcels within the Conservation Area are generally less than 200 acres in size with the average parcel size being approximately sixty acres. However, the sixteen largest property owners in the Conservation Area all own properties totaling over 800 acres each. The California Department of Forestry and Fire Protection (2010) states the larger tracts of privately held rangeland enhance that habitat. Generally, smaller parcels of land are more expensive and contain less of the ecosystem attributes and agricultural characteristics the Conservancy is trying to protect. In general, the sizes of privately owned parcels within the Conservation Area are relatively small. Smaller properties generally do not support the degree of protection of ecosystem attributes and contiguous landscapes sought after when pursuing long-term conservation efforts generally met by protecting large properties. However, some small properties may contain important landscape characteristics considered by the Conservancy to be worth protecting, particularly along the Salinas River. Table 4.1 below shows the total acreages owned by the largest landholders within the Conservation Area. The largest privately held properties are mapped in Figure A.13 in Appendix A. Land area covered by the sixteen largest properties totals approximately 41,900 acres or thirty percent of the total land within the Conservation Area. 


\begin{tabular}{|ccc|}
\hline $\begin{array}{c}\text { Property ID } \\
\text { Number }\end{array}$ & Acres & $\begin{array}{c}\% \text { Of Total Land } \\
\text { Area }\end{array}$ \\
\hline $\mathbf{1}$ & 5088.51 & $3.65 \%$ \\
\hline $\mathbf{2}$ & 1139.80 & $0.82 \%$ \\
\hline $\mathbf{3}$ & 2020.72 & $1.45 \%$ \\
\hline $\mathbf{4}$ & 1703.98 & $1.22 \%$ \\
\hline $\mathbf{5}$ & 2375.72 & $1.70 \%$ \\
\hline $\mathbf{6}$ & 2100.60 & $1.51 \%$ \\
\hline $\mathbf{7}$ & 893.39 & $0.64 \%$ \\
\hline $\mathbf{8}$ & 1356.44 & $0.97 \%$ \\
\hline $\mathbf{9}$ & 4451.51 & $3.19 \%$ \\
\hline $\mathbf{1 0}$ & 5676.77 & $4.07 \%$ \\
\hline $\mathbf{1 1}$ & 1001.11 & $0.72 \%$ \\
\hline $\mathbf{1 2}$ & 1312.48 & $0.94 \%$ \\
\hline $\mathbf{1 3}$ & 1401.62 & $1.00 \%$ \\
\hline $\mathbf{1 4}$ & 2900.43 & $2.08 \%$ \\
\hline $\mathbf{1 5}$ & 1703.98 & $1.22 \%$ \\
\hline $\mathbf{1 6}$ & 6773.26 & $4.85 \%$ \\
\hline
\end{tabular}

Source: SLO Datafinder 2011

Table 4.1 Large properties within the Conservation Area

Large properties provide intact contiguous habitat, larger diversity of wildlife species, variability in the types of habitat including oak woodland, riparian, grassland, shrub/scrub habitat and temperate and seasonal wetlands. They also contain the larger drainage areas and subsequent stretches of important streams and creeks. Of the sixteen largest properties within the Conservation Area, several of the properties are managed under the same owner(s).

Properties Nine and Sixteen are two separate ranches being operated under the same landowners. Properties Ten, Thirteen and Fourteen are all considered one ranch and operated under the same landowners. Fragmentation of landscapes increases population and types of development within the Conservation Area, which is why larger properties under the same 
landowner(s) are so important. Based on the contiguous landscape characteristic, the Conservancy should consider focusing on the southeast section of Conservation Area. These lands provide over 6,000 acres of contiguous landscape along with the several thousand acres already protected by the Los Padres National Forest.

The north and western properties, just south of the City of Atascadero, are also important because of more immediate development threats from future development. The landowners of Properties Ten and Sixteen already have plans to develop at least part of their land. Three thousand seven hundred and seventy seven acres in the central area of Property Ten are devoted to a cluster subdivision for 111 home sites. The future development sites surround the proposed agricultural residential cluster subdivision to the north of Santa Margarita and to the south and east of the subdivision. It is also proposed that 3,600 acres will be placed in agricultural conservation easements. The landowners of Property Sixteen have been working to do similar projects. The ability to work with these landowners on conservation projects on their property is not known, but landowners of these properties have expressed interest in protecting at least part of their land under conservation easements.

\subsection{Contiguous Protected Land}

Public land consists of over fifty percent of the Conservation Area. The largest privately owned properties within the Conservation Area add up to over thirty percent of the total land area. This suggests a real opportunity for the protection of large contiguous landscapes. Protection of areas adjacent to existing protected land maintains continuity of important habitat and ecosystem features. Many of the large privately held properties abut public land throughout the Conservation Area. Large properties that abut public land include: Properties One to Ten, Twelve, Fifteen, and Sixteen. Figure A.13 in Appendix A is a map of large tract properties and their relationship to public land and each other. Land under public ownership consists of almost 
fifty-four percent of the land acreage within the Conservation Area. The largest privately held properties equate to approximately thirty percent of the Conservation Area.

Several properties have already been in negotiation with or have entered into conservation agreements within the Conservation Area. The landowners of Property Ten have entered into a 333-acre conservation easement with the Rangeland Trust (California Rangeland Trust 2010). As a result of the proposed cluster development on Property Ten, further conservation easements are in negotiation with the County of San Luis Obispo and number of conservation organizations. The landowners of Property One are working on a conservation easement agreement with the Rangeland Trust (Steve Sinton personal interview 2011). The landowners of Property Sixteen are also negotiating conservation agreements with the Conservancy, according to their website (Eagle Ranch Inc 2008). The landowners of Property Two have recently placed a conservation easement on their property in partnership with the Land Conservancy of San Luis Obispo County. Potential land conservation, along with existing protected land in the region, would ensure the continuation of cattle ranching and agriculture in the region as well as the permanent protection of large contiguous tracts of open space, ensuring areas protected for wildlife habitat and a healthy functioning watershed.

\subsection{Development Potential}

In general, the Conservation Area is not considered to be under immediate threat due to the rugged terrain and distance from urban growth centers, although several development proposals are in the works on Properties Ten and Sixteen. In general, the larger properties in the north and western portion of the Conservation Area are under more threat of urban development than the large properties in the rest of the Conservation Area. All properties with prime agricultural soils that have not already be converted to agriculture are prone to conversion to more intense agricultural land uses. The location of Highway 101 and location of major 
arterial roadways connecting the town of Santa Margarita to other parts of the Conservation Area are a transportation corridor infrastructure that makes it easier for development and the movement of goods and services to occur in and around the area. Major roadways that intersect the Conservation Area include: West Pozo Road, Highway 58 (Calf Canyon Road), Highway 229 (Webster Road), and Parkhill Road, all of which intersect the Conservation Area. It is hypothesized that most of the development that would occur would happen along these roadway corridors on the relatively flat grassy rangeland areas that make up the Salinas River Terrace and valley between the Santa Lucia and La Ponza mountain ranges. Figure A.14 in Appendix $A$ is a map of existing urban and exurban development along with urban reserve lines, areas used for agriculture and major roads in the Conservation Area.

The most eminent threats to landscapes in the region are more intensive land uses such as row crop agriculture and urban development primarily in the northern portion of the Conservation Area. The rural structural development and agriculture in the region exist primarily in the valleys, the Salinas River and many of the subsequent tributaries. Most of the row crop agriculture within the Conservation Area is alfalfa hay, vineyards and to a lesser extent, grain production. There are known vineyards on Properties One, Three, and Ten. Areas known to have vineyards according to 2009 imagery produced by Google Earth includes an area surrounding the Pozo URL along Pozo Creek, along a tributary of Rinconada Creek on Property Nine and on Property Ten along Trout Creek. Aerial photography suggests that these properties contain area with tilled row crop agriculture such as hay and vineyard products. Irrigation for row crop agriculture would put increased pressure on ground water resources in the area. Figure 4.1 is an aerial photograph of an area containing dryland agriculture and vineyards within the Conservation Area near the Salinas River. 
Figure 4.1 An aerial photograph of dryland row crop agriculture and vineyards near the Salinas River within the Conservation Area

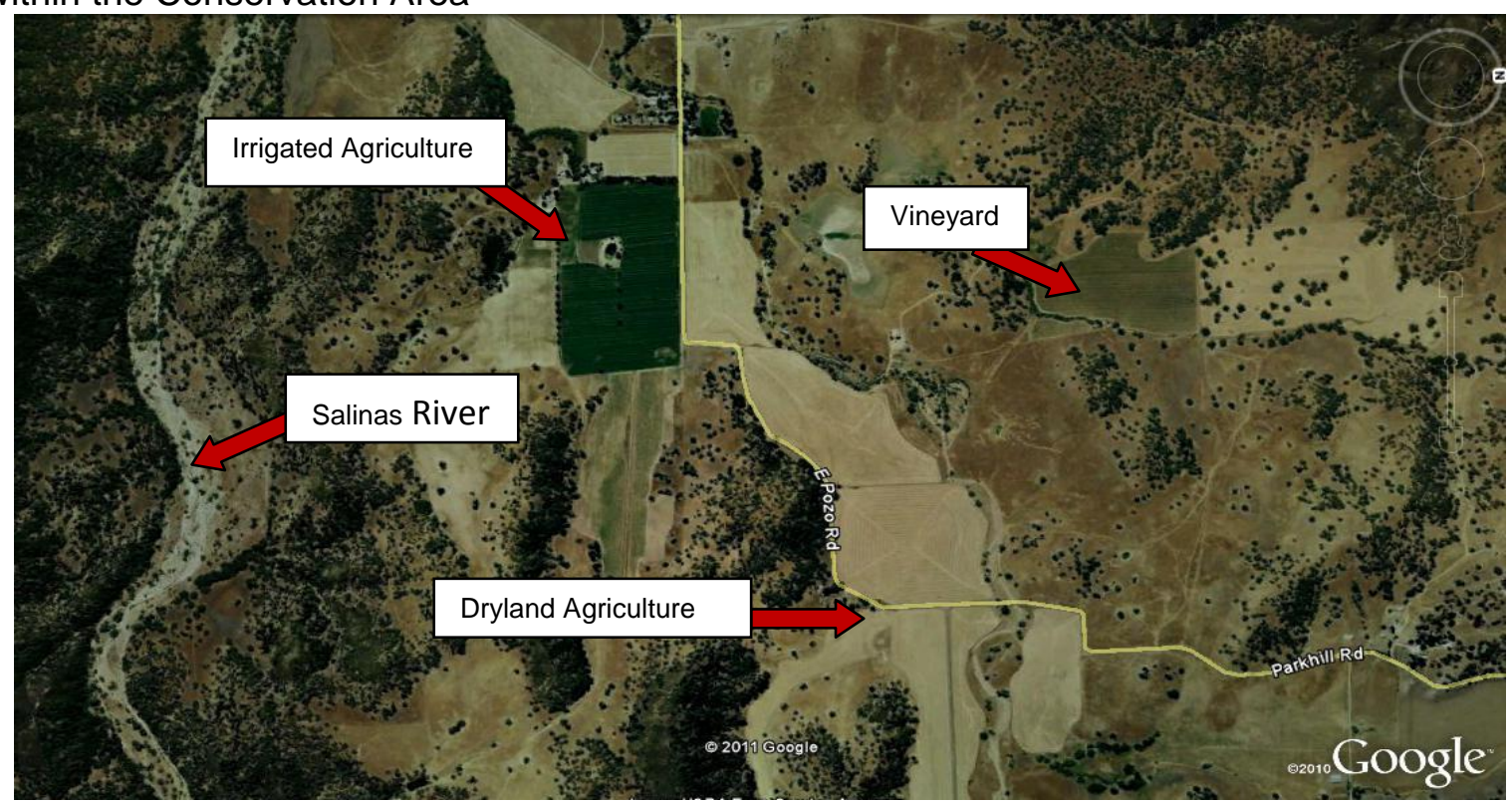

Tilling practices of intensified agricultural land uses could result in increased erosion rates, although methods exist to reduce soil erosion on agricultural fields. Non point source pollution from agriculture makes waterways susceptible to degraded water quality and increased eutrophication downstream. Many of the tributaries to the Salinas River that have row crop agriculture abutting the water ways have little to no riparian buffer protection as indicated by aerial photography. Named streams and tributaries where high intensity agriculture occurs include:

- Salinas River

- Pozo Creek

- Toro Creek

- Rinconada Creek
- Pilitas Creek

- Trout Creek

- Santa Margarita Creek

- Atascadero Creek

There are a couple of mining operations that exist within the Conservation Area, primarily along Highway 58 and along the Salinas River. Most of the mining operations are in stream gravel mining and aggregate quarries where concrete and asphalt are manufactured and recycled. The largest mine/quarry is approximately six miles below the Santa Margarita 
Reservoir. The mine stretches approximately for one mile along the Salinas River. Mines are an intensified land use that, depending on what is being mined and the type of mining, can have negative impacts on air quality and water quality. Steelhead migration and spawning are particularly hindered by in stream gravel operations within the Salinas River. See Figure 4.2 for an example of a mining operation along the Salinas River.

Figure 4.2 Aerial photograph of a mining operation along the Salinas River

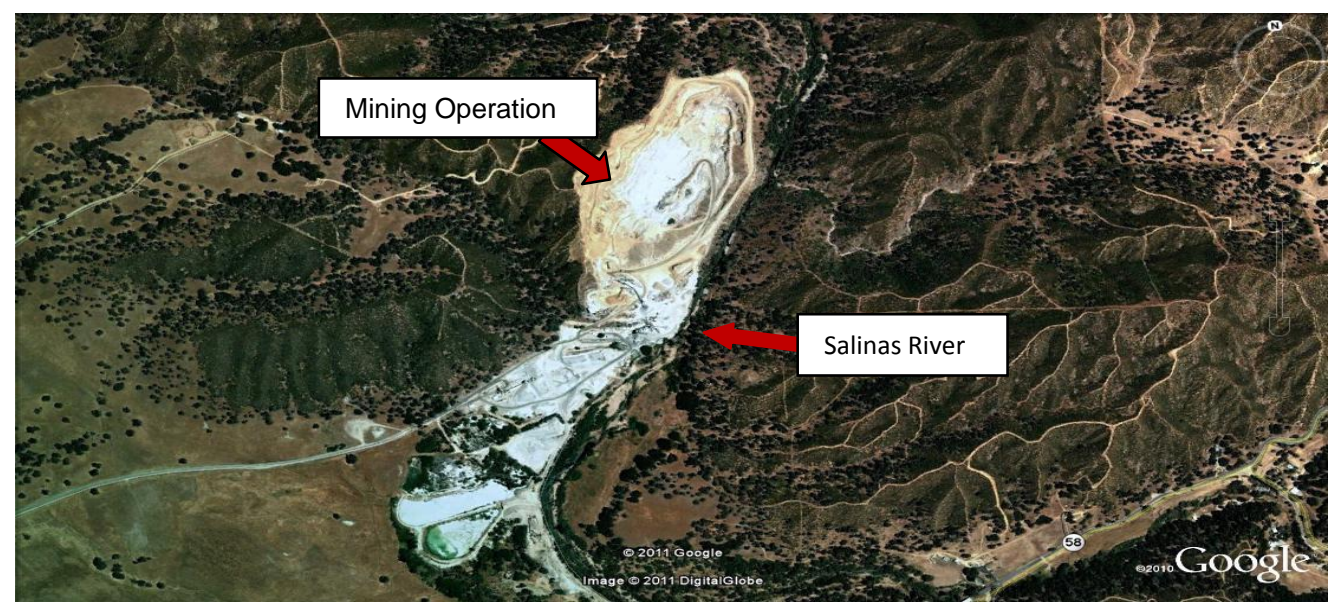

\subsection{Habitat Diversity}

Habitat variety is critical to supporting a number of floral and faunal species. The vegetation communities mentioned earlier indicates the diversity of these habitat types and is individually mapped and found in Figures A.6 in Appendix A. While major communities are outlined in previous sections, the variability in the terrain presents pockets of smaller communities, which vary depending on species dominance, slope, soil and precipitation.

Shrub types occur throughout the Conservation Area, but dominate the higher elevations and are largely protected by the Los Padres National Forest. Below the Santa Margarita Reservoir, shrub vegetation surrounds the Salinas River as it travels north towards Atascadero. Much of the shrub habitat north of Santa Margarita Reservoir is on private land. 
Herbaceous vegetation dominantly occurs on the foothills, river terraces, and intermittently within small valleys scattered throughout the Conservation Area. These areas are important for raising cattle and a lot of these areas have be converted into other agricultural uses such as hay, vineyards and grains. Herbaceous vegetation areas are prone to threats of more intense agricultural uses because much of the prime agricultural soil found in the Conservation Area is located within the areas where this vegetation type is found.

Wetlands and marsh areas are interspersed throughout the Conservation Area, but the area they cover is generally small compared to other vegetation communities. Wetland and marsh areas equate to about 287 acres, totaling less than one percent of the land area. The majority of the marsh and wetland areas exist in the flood plains of the Salinas River and its major tributaries. Larger wetland and marsh areas exist on Santa Margarita Ranch along Santa Margarita Creek. An aerial photograph from Google Earth (2009) indicates that there is a relatively large wetland area on private land not identified as a large property mentioned above. This area exists between Properties Nine and Ten and is situated between large acreages of vineyards. See Figure A.9 in Appendix A for a map of riparian and wetland areas within the Conservation Area. Other wetlands and marshes exist as stock ponds for cattle on grassland areas or as retention basins such as the marshland adjacent to Santa Margarita.

There are several small ponds and lakes that exist within the Conservation Area. Most of these ponds and lakes are located either on public land, particularly near the Santa Margarita Reservoir, or on the large properties within the Conservation Area. 


\subsection{Oak Woodland/Hardwood Diversity}

Oak woodland and other hardwood species provide important habitat functions that have been a defining characteristic of the region's oak savannah woodland communities. Several species of oaks exist within the Conservation Area. Promoting diversity of tree species is important. Project selection priority should be partially based on a particular property's diversity of oak and mixed hardwood stands. GIS analysis was used, but on-the-ground assessments should be performed to collect accurate field data. Figure A.8 in Appendix A shows a snapshot of oak and mixed hardwood stand diversity and their locations. Large private properties are shaded in gray in Figure A.8 in Appendix A. Much of the diversity occurs in the valley, on the terrace, and in the river and stream floodplains. Blue oak tends to dominate the canopy as the valley narrows in the southeastern end of the Conservation Area. According to the GIS data from the County of San Luis Obispo (Aerial Information Systems 2009), the larger properties in the north and western side of the Salinas River (Properties Nine to Fourteen and Property Sixteen) followed by the area surrounding Pozo, have more vegetative community diversity than the other properties throughout the Conservation Area. Figure A.8 in Appendix A is a map of the vegetative communities within the Conservation Area.

\subsection{Stream Corridors}

Riparian areas exist where there are surface water drainages present for all or part of the year. Most of the agricultural and some industrial mining operations occur immediately adjacent to riparian areas. Providing habitat and a buffer to non-point source pollution problems, riparian vegetation finds itself under threat from these more intensive land uses. The Natural Resource Conservation Service recommends a minimum forest riparian buffer of 35 feet on either side of the stream with a minimum active floodplain of 105 feet (no diking or construction of levees). All in all, this should comprise thirty percent of the active flood plain. 
Some of these riparian areas are not naturally forested and contain shrub or grassland vegetation. However, some stream channels contain little or no vegetative buffers. A report by the Environmental Protection Agency on buffer width and a review of the science and regulations states that larger riparian buffers (fifty feet and above on either side of the channel) consistently are more effective than smaller riparian buffer strips at removing nitrogen, phosphorus, and other pollutants in conjunction with other BMPs to reduce point source and non point source pollution. They considered small riparian buffers to be one to fifteen feet on either side of the channel (Mayer et al.. 2006). Figure A.9 in Appendix A shows the location of intact riparian corridors. The more stream corridors in existence on a property, the higher the priority value of the property. Generally, properties containing major tributaries and the Salinas River have higher conservation value. Of the largest properties considered, properties containing major tributaries include: Property One, Properties Three to Seven, and Properties Nine to Sixteen.

\subsection{Quality Rangeland/Soils}

See Figure A.15 in Appendix A for a visual illustration of herbaceous vegetation locations throughout the Conservation Area. Herbaceous vegetation in this region is comprised primarily of annual and perennial grasslands. Grassland utilized for grazing of livestock that may or may not contain stands of oak woodland species is considered rangeland. Much of the available rangeland areas are located along tributary floodplains at higher elevations and along the Salinas River terrace. Cattle grazing does occur in shrub or tree communities where forage species such as grass grow, but to a lesser extent. Livestock feeding in these communities on herbaceous forage material generally need to have larger areas to feed in order to meet their nutritional requirements and livestock management goals. 
Figure A.17 in Appendix A shows the location of soils of state significance and prime farmland soils, where the County of San Luis Obispo has ordinances that severely discourages development growth on these soils. Most of the quality soils are located along the major roadways in the area and are located on private land. Much of these quality soils are currently utilized as row crop agriculture such as vineyards and dryland farming, but are also used for livestock grazing in some areas. Most of the soils are located to the west of the Salinas River, but several more fragmented areas exist to the east and south of the River. Waterways that are surrounded by these soils are primarily Trout Creek, Yerba Buena Creek, Rinconada Creek and along the Salinas River floodplain and terrace. Most of the larger properties identified above contain some degree of prime agricultural soils. All the large properties identified in Figure A.13 in Appendix A contain important soil designations with the exception of Property Fifteen.

Well managed rangeland plays an important role in habitat connectivity for a diverse number of plant and animal species, it also can aid in creating high quality soils to improve forage quality for livestock, reduce erosion and sediment loads being carried into drainages and is part of the natural beauty of the Upper Salinas Watershed that keeps many ranchers in the cattle business. 


\subsection{Erosion Potential}

Erosion potential is an important characteristic determined by slope, soil type, vegetation availability, agricultural practices, development and the presence of roads and construction associated with both development and roads. High erosion potentials can result in high levels of run-off and non-point source pollution into waterways. High erosion potential areas need to be protected from harmful land uses in order to reduce and/or prevent increased erosion rates. Some erosion areas were identified and evaluated based on a number of factors including slope, soil type, $\mathrm{k}$ factor, existing development and the amount of existing impermeable surfaces. Further evaluation is necessary in order to fully understand erosion potential as a conservation criterion. Erosion modeling programs exist to help assess erosion potential for particular areas, but were not used in development of this plan. Further erosion analysis should be performed to further assess erosion potential within the Conservation Area.

\subsection{Multiple Criteria Test}

The multiple criteria test is an evaluation of the lands within the Conservation Area based on the number and degree of each area being evaluated and having the landscape characteristics mentioned above. Generally, the more landscape characteristics a particular area has, the more consideration it is given for priority conservation. Many properties within the Conservation Area fit the multiple criteria test. Typically, larger properties encompass several characteristics that make them a more desirable target for conservation. The size of the property, location in relationship to public land that form large contiguous landscapes, containing major tributaries, and other landscape characteristics mentioned above are important attributes of a property being considered for conservation projects.

Protection of landscape attributes within the Conservation Area is particularly important to protecting important water resources. Above Santa Margarita Reservoir, ecological 
characteristics on private property are perceived to be under a less immediate threat due to their relative location to expanding urban areas such as Atascadero. However, the Pozo URL and nearby existing roads provide some existing development infrastructure such as transportation corridors and utility services. This area is important because of the relatively intact and healthy watershed system. Private property in the immediate area is also important because of their relationship to large contiguous parcels of public land. Large private properties throughout the Conservation Area are relatively close in proximity, both to each other and to already protected land (primarily public land). Protecting these landscapes also fit the multiple criteria test; combined with existing public lands, they would provide large-contiguous protected landscapes consisting of multiple vegetation communities providing significant wildlife corridors for many bird, reptile, amphibian and mammal species. The Salinas River and its tributaries also meander over these private landscapes. Protection of these headwater regions is essential to maintaining a quality water source to downstream users such as Atascadero, Paso Robles and San Luis Obispo. Headwaters are sensitive to intensified land use changes resulting in degraded water quality critical to ensuring healthy and safe water supplies and water quality will result (Allan 2004).

Evaluation of properties with multiple landscape characteristics important to the Conservancy is needed in order to identify and pursue conservation priorities. Additional characteristics or the importance of one characteristic over another may change depending on the needs of the Conservancy and partnering entities including the landowner. 


\subsection{Restoration Analysis}

Restoration is an important component of long-term conservation within the Conservation Area. In order to evaluate restoration needs, the Conservancy should work with partnering landowners, agencies and organizations to identify project areas, secure funding and develop and implement restoration plans. Properties with long-term conservation agreements already in place should be emphasized for restoration projects because they provide a more secure and longer range investment in conservation. In order to fully address water quality needs and habitat objectives, interested parties should perform field assessments of areas to fully evaluate restoration and enhancement needs. Restoration projects can vary in the scope of the project. Projects can vary in the need for personnel, equipment and financial resources. Potential in stream project areas, invasive species project sites and areas needing brush management were not assessed due to the inability to identify problem areas using GIS and aerial photography. Partners in restoration projects should work to improve sedimentation/erosion control, habitat and increase forage production simultaneously where feasible. Restoration/enhancement efforts are meant to improve these conditions.

The emphasis in this section is on stream channel and riparian restoration. Due to the dam acting as a barrier to steelhead migration, efforts above the Santa Margarita Reservoir should focus on water quality (sediment, erosion control and bank stabilization); although riparian buffers, stream shading and morphological features should be considered to provide habitat for fish species that live above the reservoir. When possible, restoration projects should work to improve water quality and provide a benefit to wildlife. However, restoration above the reservoir should emphasize grade control, channel stabilization, sediment and nutrient buffers, etc. 
Flood prone areas such as areas on the Yerba Buena and Santa Margarita Creeks should maintain natural morphology and a sufficient floodplain buffer to dissipate the effects of flood and control sedimentation. Logjams should be removed to prevent any potential flood hazards. Santa Margarita Creek also contains populations of southern/coastal steelhead trout on the upper most section of the Salinas River. Habitat improvements to provide adequate riffle-pool and gravel bed dynamics along with riparian buffers to regulate in stream temperatures can help to provide sufficient habitat for breeding and the first stages of the steelhead life cycle. Information on habitat restoration techniques for salmonid streams can be obtained from the California Department of Fish and Game's California Salmonid Stream Habitat Restoration Manual fourth edition (2010).

There are many different techniques and suggestions to go about restoring areas depending on the location, end objectives and specific site situations. This plan is concerned with stream health, water quality, wildlife habitat, important vegetation areas such as oak stands and producing viable forage on the land for ranchers and their cattle. Aerial photography can provide some insight into locations needing rehabilitation or enhancement, but ultimately site visits are necessary to verify and further identify areas in need of restoration. The interest in restoration may be part of the negotiation process with landowners with regards to working with them on long-term conservation agreements. Restoration work takes proper planning from stakeholders, technical expertise both in the planning stage and on the ground, willingness from the landowner and work with agencies of varying jurisdictions to receive proper permits. Selection of the proper restoration method requires technical expertise from a consultant or an agency. Funding to compensate landowner and organization efforts may also be available. 
While restoration efforts should focus on protecting healthy habitat and hydrologic functions, other areas of restoration are important. These include brush removal/management projects to reduce fire hazards and increase forage production; noxious weed control to help protect /increase biodiversity, increase forage production and reduce fire hazards; and upland revegetation projects to increase habitat, protect upland areas from erosion, and manage wildlife.

Tributaries are prone to increased sedimentation and nutrient loading due to agricultural encroachment, lack of riparian buffers, presence of access roads and a lack of investments in adequate seasonal stream crossing structures (the cost of putting in a culvert or building a bridge for a seasonal stream may be cost prohibitive for rangeland and/or agricultural access roads). Attention to seasonal tributary enhancement project areas, particularly on conservation properties, can help improve water quality and provide increased riparian habitat and migratory corridors for wildlife. 


\subsection{Goals, Objectives and Actions}

The Upper Salinas Watershed within the Conservation Area is a healthy ecosystem that supports important habitat for wildlife, a quality surface and ground water supply and valuable range and farmland production. Despite these characteristics, the watershed faces

environmental and social challenges that could affect the landscape's ecosystem functions and the agriculture that it supports. Below are the goals, objectives and actions intended to provide a framework and plan of action for the long-term protection of valuable resources within the Conservation Area.

There are four primary strategies that should be employed in order to protect and improve the quality of the Upper Salinas Watershed. The primary strategies are:

1.) Land use policy and planning framework (discussed in Section 3.13)

2.) Conservation agreements (easements and acquisitions)

3.) Long-term management practices

4.) Restoration and habitat improvements

Appendix I serves as the functioning planning mechanism for the Upper Salinas Headwater Conservation Area. More detailed illustrations, facts, figures and descriptions of the objectives and action items can be found in Appendix I. Actions listed under each objective primarily come from the Natural Resource Conservation Service's National Handbook of Conservation Practices. The actions listed under each objective are numbered and correspond to the number as they appear in the National Handbook of Conservation Practices for further reference. Table $\mathrm{J} .1$ in Appendix $\mathrm{J}$ is a table of BMPs and other conservation practices and techniques used to improve rangeland ecosystem structure and function. Table J.1 in Appendix J shows how conservation practices can improve a number of ecosystem, land and livestock management goals. Many of the action items serve multiple purposes such as reduce erosion, 
create habitat and increase forage. While this is not an exhaustive list of available practices, these actions items often are most effective when utilized together.

The goals, objectives and action items in this section aim to provide a feasible, holistic and balanced management system that increases working landscape viability and protects wildlife and ecosystem resources. In addition to this conservation plan, landowners and managers should work with appropriate agencies such as NCRS and the Resource Conservation District, or a private consultant to develop land management plans specific to the desired management goals and objectives that consider opportunities and limitations of the land and climate. Development of these plans should include management for nutrients, habitat, residual dry matter, grazing system, erosion control, brush/noxious weeds, and fire. Below are the goals, objectives, and actions recommended for the Conservancy, landowners, agencies, and organizations working to protect rangeland, farmland, the ecosystem and the people that live and work on these lands.

\section{Goal 1: Private land within the Conservation Area will be protected and restored to provide sufficient food, breeding habitat and cover for native wildlife species.}

Objective 1.1: Work with landowners to establish long-term conservation agreements including but not limited to conservation easements and land acquisitions to protect private land from the threat of development and intensification of land uses.

Action 1.1.1: The Land Conservancy shall work to partner with landowners of the large properties near already protected landscapes identified in Section 4.4 of the Upper Salinas Headwaters Conservation Plan.

Action 1.1.2: The Land Conservancy should develop a public outreach plan that includes initiating contact to develop a working relationship with interested landowners and appropriate agencies and organizations. This may include phone calls to individuals, attending local Cattlemen Association meetings, workshops, etc. 
Action 1.1.3: The Land Conservancy shall provide outlets for unexpected land conservation opportunities. Opportunities will be evaluated through the Land Conservancy's existing conservation review process. It is possible that a landowner wanting to partner with the Conservancy will approach the Conservancy. These landowners may not have initially been in the scope of priorities for the Conservancy. Projects proposed by willing landowners should be evaluated through the formal staff, Land Committee, Board of Directors review process to determine if these opportunities are worth pursuing.

Action 1.1.4: The Land Conservancy shall develop a program that will recognize and award landowners and partners in the completion of successful projects. Proper recognition and credit should be given to landowners and partnering agencies and organizations. Successful agreements should be publicly celebrated, highlighting the land and landowners where possible.

Action 1.1.5: The Land Conservancy shall work with conservation partners to establish agreements that are mutually beneficial for the Conservancy and the landowner. Agreements should be flexible for landowners and provide the important long-term resource and ecosystem protection. This will allow landowners to be adaptable to changing markets in order for them to continue to have viable operations, but rigid enough to protect ecosystem and landscape features from different types of potential future development. Agreements should include mutually agreed upon allowable uses including future development and agriculture, inclusion of potential restoration projects on the property, and how enhancement projects will be implemented, funded and the agencies, landowner, and organization responsible for taking the lead on particular projects.

Action 1.1.6: The Land Conservancy shall work with conservation partners to develop specific conservation objectives for individual properties, establish indicators, collect baseline data and a plan of action to achieve objectives. This may include the preservation and recommended projects for enhancement of particular landscape resources. Establishing objectives and specific plans of action for each property will also provide the indicators for a monitoring protocol to ensure that conservation objectives are being met.

Objective 1.2: Protect and restore damaged or degraded habitat areas important to wildlife on already protected private land. 
Action 1.2.1: The Land Conservancy shall work with willing landowners to identify areas of particular ecosystem and habitat features that have been damaged or degraded. This includes review of available maps, aerial photography and site visits with the landowner.

Action 1.2.2: The Land Conservancy and its partners shall work to secure funding to carry out restoration and land management projects.

Action 1.2.3: $(658,659,657)$ The Land Conservancy, landowners and/or other partnering entities shall work to enhance damaged or degraded wetland areas on lands with existing longterm conservation agreements.

Action 1.2.4: (644) Landowners, land managers and other essential entities should work to manage wetland areas for native wildlife species. Wildlife species management goals and objectives should be identified. Types, amount and distribution of necessary habitat elements and management actions should be developed for desired species.

Action 1.2.5: (396) Landowners, managers and/or hired consultants should work to modify or remove man-made structures that impede migration of steelhead and other aquatic organisms. Removal of barriers such as logjams, man-made dams and other impediments allow for increased utilization of in stream habitat by aquatic species and allows for migrating species such as steelhead to reach historic breeding habitat further up stream.

Action 1.2.6: (645) Landowners and land managers should work to develop and implement a habitat management plan for upland wildlife species. The Land Conservancy and landowner may negotiate conservation agreement terms that establish particular responsibilities and obligations to complete habitat management plans.

Objective 1.3: Protect the habitat values found in each vegetation community.

Action 1.3.1: (528a) Landowners and/or land managers should employ a prescribed grazing system based on pre-determined management objectives. 
Action 1.3.2: (472) Landowners should employ livestock exclusion techniques in order to protect riparian areas and any other critical area such as areas being restored, critical habitat, and areas with sensitive hydrological functions.

Action 1.3.3: Cattle operators and operation owners should implement off-site attractants to lure cattle away from specific areas, particularly riparian areas.

Action 1.3.4: (612) Landowners, land managers, and/or any relevant partnering agencies or organizations should establish native trees, grasses and shrubs by planting seeds or woody cuttings to improve wildlife habitat, reduce erosion, improve water quality, and improve biological diversity in appropriate areas.

Action 1.3.5: (314) Landowners and land managers should utilize brush management through the use of prescribed fire or selective manual removal that will keep some desirable brush for habitat, reduce fuel loading, increase vegetation composition and therefore increase biodiversity on the landscape.

Action 1.3.6: Landowners and land managers should implement a noxious weed management plan using fire, grazing and manual removal to control the proliferation of noxious weeds and to promote the growth of native vegetation species composition, which provides sufficient food and cover for a variety of wildlife species.

Action 1.3.7: Landowners should individually or with partnering consultants, agencies and organizations, develop, design and implement management guidelines that consider amphibian migration and breeding as well as bird nesting seasons that can help to increase species survivorship and productivity.

Action 1.3.8: (516) Where feasible, landowners and/or managers should construct a water conveyance system that minimizes energy use (i.e. gravity-fed) and provides water sources to areas away from riparian areas and other ecologically sensitive areas to keep cattle away.

Action 1.3.9: Landowners should construct fence lines for perching birds in areas that need plant regeneration for grassland restoration and bird and bat boxes to help provide seed dispersal and supplement pest management. 
Objective 1.4: Build partnerships with agencies, organizations and landowners to obtain proper financial and technical resources to plan and implement protection and enhancement projects.

Action 1.4.1: Initial work with willing landowners should include discussions about areas where rehabilitation/improvements can be made. In addition to establishing conservation agreements such as easements, the Conservancy will work with landowners to develop restoration/enhancement project plans to improve wildlife habitat.

Action 1.4.2: Outreach with other agencies and organizations whose priorities are in line with project goals. Willing landowners and the Conservancy will work to establish appropriate partnerships with agencies and organizations who can contribute essential resources and technical expertise to the specific project including help to secure appropriate funding, permit streamlining, project design, and construction.

Action 1.4.3: Help landowners navigate and/or streamline permitting/regulatory processes for restoration and enhancement projects and to be a resource to connect landowners with funding to implement BMPs and new technologies towards land management practices.

Goal 2: Maintain and where feasible, protect and improve a safe and clean water supply.

Objective 2.1: Prevent and reduce upland erosion, runoff, and sedimentation.

Action 2.1.1: (528a) Operation owners and land managers should employ a prescribed grazing system based on pre-determined management goals.

Action 2.1.2: (472) Operation owners and managers should utilize livestock exclusion techniques such as fencing in order to protect areas sensitive to erosion and areas that are establishing or reestablishing vegetation. 
Action 2.1.3: (612) Landowners and land managers should work to establish native trees, grasses and shrubs by planting seeds or woody cuttings to help capture sediment and reduce runoff/erosion, improve water quality, and improve biological diversity in appropriate areas.

Action 2.1.4: (345) Operation owners and managers should manage plant residue such as Residual Dry Matter (RDM) to help slow runoff and trap erosion in upland areas.

Action 2.1.5: (484) Operation owners and managers should use mulch in over grazed areas or bare ground areas to control erosion caused by runoff and propagate the growth desirable to plant species. Mulching can include most types of organic matter including wood chips, hay, and mixed debris.

Action 2.1.6: Landowners in partnership with restoration specialists and consultants should utilize rip rap where appropriate. Construct a "blanket" of appropriately sized rock to protect hill slopes, irrigation ditches, channels, and stream banks from erosion. In sensitive habitats plantings should be integrated into rip rap to mitigate for potentially negative effects on wildlife.

Action 2.1.7: Landowners in partnership with restoration specialists and consultants should utilize revetments where appropriate. Place material on the banks of ditches, channels, and streams to prevent surface erosion and scour. This practice reduces the potential for mast wasting, protects structures, and improves water quality.

Action 2.1.8: Landowners in partnership with restoration specialists and consultants should utilize the construction of terraces where appropriate in order to provide a level or slightly concave surface for supporting plant growth, and intercepting surface runoff.

Action 2.1.9: (560) Landowners in partnership with restoration specialists and consultants should construct access roads and stream crossings, if appropriate, in a manner that prevents and reduces runoff and subsequent erosion into waterways.

Action 2.1.10: (575) Operation owners and managers should work to establish stock trails and pathways in a way that reduces erosion and soil compaction. 
Action 2.1.11: (453) Landowners, in partnership with restoration specialists and consultants, should identify areas with existing and potential erosion problems and apply treatments to prevent and/or stabilize landslides to stop excessive erosion and sedimentation.

Action 2.1.12: (603) Landowners and land managers should work to establish herbaceous vegetation wind barriers in rows or narrow strips in the field across the prevailing wind direction to reduce wind erosion, protect crops from dust, and to provide food and cover for wildlife.

Objective 2.2: (391, 393) Maintain and/or improve riparian buffers along streams, wetland, vernal pools, etc.

Action 2.2.1: (528a) Operation owners and managers should employ a prescribed grazing system based on pre-determined management goals.

Action 2.2.2: (472) Operation owners and managers should utilize livestock exclusion techniques to protect riparian corridors.

Action 2.2.3: Operation owners and managers should utilize alternative water sources where available such as stock ponds, well development, and spring development troughs.

Action 2.2.4: (612) Landowners and land managers should plant native trees and shrubs to establish a vegetation canopy and sub canopy species.

Action 2.2.5: (412) Landowners in partnership with restoration specialists and consultants should identify areas needing erosion control measures and implement grassed waterways if appropriate. Construct channel with established vegetation suitable for carrying surface water in a non-erosive manner to a stable outlet.

Action 2.2.7: (484) Landowners and land managers should use mulch in over grazed areas or bare ground areas to control erosion caused by runoff and propagate the growth desirable plant species. 
Action 2.2.8: (350) Landowners, in partnership with restoration specialists and consultants, should develop sediment basins in areas where increased erosion and sedimentation can be prevented from entering streams if appropriate.

Action 2.2.9: Landowners, in partnership with restoration specialists and consultants, should construct waste treatment lagoons if appropriate to trap livestock waste water and keep it from reaching creeks or streams. The construction of ponds should be implemented using an embankment or digging a pit with the purpose of intercepting waste discharge/runoff from facilities such as confined animal operations with the intent of biologically treating waste, such as manure and wastewater, thus reducing pollution in sensitive waterways.

Action 2.2.10: $(378,574,453,642)$ Operation owners and managers should develop stock ponds, springs, wells and troughs to keep cattle out of managed areas.

Action 2.3.1: Operation owners and/or managers should place sharp rocks in in-stream cattle crossings to make it uncomfortable for cattle to stay in the stream or wetland area.

Action 2.2.11: (575) Operation owners and managers should limit the creation and use of cow paths, which increase erosion and subsequent sedimentation. See Action 2.1.10 for more details.

Action 2.2.12: (410) Landowners, in partnership with restoration specialists and consultants, should work to stabilize the grade and control erosion in channels using a structure to prevent the formation and advancement of gullies, enhance environmental quality, and reduce pollution hazards.

Objective 2.3: (580) Identify potential stream restoration project areas on protected private land and develop and implement plans to protect water quality.

Action 2.3.1: Work with willing landowners to develop management goals, discuss and visit areas with known severely degraded riparian sites, stream bank erosion, debris or logjams that have resulted in the creation of a new channel areas where the stream or drainage has been artificially straightened and channelized. 
Action 2.3.2: (580) Implement stream bank and channel grade stabilizing techniques where appropriate. Many techniques are available to provide stream bank, channel, and riparian stabilization.

Action 2.3.3: (322) Plant vegetation in areas lacking riparian vegetation, trees, shrubs and willow poles to provide habitat and channel bank stabilization.

Action 2.3.4: (580) Plan and implement restoration and preventative enhancement techniques to provide channel stabilization where stream banks and in stream morphology are damaged, in danger of being damaged or causing sever runoff and erosion problems and contributing to large inputs of sedimentation.

Objective 2.4: Help landowners and organizations locate and utilize funding and technical resources including obtaining permits and grant money for in stream and stream bank restoration projects

\section{Goal 3: Rangeland, ranching viability and the agricultural heritage associated with the region will be protected now and into the future.}

Objective 3.1: The Conservancy shall work with landowners identified in the Upper Salinas Watershed Conservation Plan to establish long-term conservation to keep agricultural and rangeland in production.

Action 3.1.1: The Land Conservancy shall work with landowners who own large properties near already protected landscapes such as public properties with existing conservation easements.

Action 3.1.2: The Land Conservancy shall initiate contact with landowners whose properties have been determined to be a priority for conservation to determine the appropriateness of developing partnerships for future conservation efforts. 
Objective 3.2: Increase forage production and utilization by protecting existing soil and vegetation characteristics.

Action 3.2.1: (528a) Operations owners and managers should develop a prescribed grazing system that meets operational and ecosystem objectives.

Action 3.2.2: (345) Operation owners and managers should manage for targeted levels of residual dry matter to promote regeneration of grassland forage vegetation.

Action 3.2.3: (484) Landowners and land managers should use mulch material such as straw, wood chips, etc. to provide temporary upland erosion control, water retention, noxious weed control and generation of desirable plant species.

Action 3.2.4: (314) Land owners and land managers should develop and implement brush management using fire, grazing and/or manual methods that can provide brush habitat for wildlife in some places, and removal of brush can also lead to increased forage production.

Action 3.2.5: $(342,327)$ Landowners and managers should identify highly erodible areas and implement a critical area-planting program.

Action 3.2.6: $(550,512)$ Landowners and land managers should utilize reseeding techniques to improve rangeland habitat and forage production.

Action 3.2.7: (334) Landowners, in partnership with restoration specialists and consultants, should establish noxious weed management plans and implement plans to eradicate noxious weed growth and promote native plant species. Controlling noxious weeds to maintain existing native forage species diversity can be implemented using a combination of fire management practices, controlled grazing or manual removal, chemical treatments and biological controls depending on species reproductive and growth characteristics as well as management objectives.

Action 3.2.8: (334) Landowners and managers should utilize prescribed burning methods in combination with other brush and invasive removal methods to setback succession, reduce brush and invasive species, and reduce competition for reseeding sites. 
Action 3.2.9: Operation owners and managers should develop a forage monitoring program to monitor RDM, forage rates, climatic conditions, soil quality, etc. based on land management objectives and baseline data.

Objective 3.3: Utilize sustainable farming practices to produce healthy crops, reduce/minimize erosion and protect water supply and quality

Action 3.3.1: Operation owners and managers should implement structural practices for crops where appropriate. This includes constructing or otherwise implementing projects that reduce pollution into nearby waterways.

Action 3.3.2: (329) Operation owners and managers should implement conservation tillage practices; grow crops with the minimum amount of tillage necessary to manage pests and reduce compaction.

Action 3.3.3: (328) Operation owners and managers should apply crop rotation practices where appropriate.

Action 3.3.4: (340) Operation owners and managers should utilize cover crops where appropriate. The use of cover crops is frequently used to control pests, weeds, erosion, and help establish or maintain desired nutrient balances and/or retain soil moisture.

Action 3.3.5: Landowners and land managers should establish narrow bands of permanent vegetation on hill slopes that are farmed on the contour to reduce sheet and rill erosion, reduce sediment and other water-borne contaminants transport, and increase infiltration.

Action 3.3.6: Operation owners and managers should utilize standards developed by the California Sustainable Winegrowing Alliance 's Best Management Practices in the Code of Sustainable Winegrowing Practices Self-Assessment Workbook.

Action 3.3.7: Operation owners and managers should implement an irrigation system where all necessary equipment and facilities are installed for efficiently and uniformly applying irrigation to 
maintain soil moisture at the necessary level to grow crops without causing excessive water loss, erosion, or water quality impairment.

Action 3.3.8: Operation owners and managers should develop water conveyance structures or systems to prevent water logging of soil, maintain water quality, and reduce water loss where appropriate.

Objective 3.4: Continue to learn about sustainable management techniques, where to find financial and technical resources and share success and innovative management practices and projects with the broader ranching, scientific and environmental community.

Action 3.4.1: Operation owners, managers as well as organizational and agency personnel should attend UC Extension Service rangeland management workshops, NRCS rangeland management workshops, California Rangeland Conservation Coalition meetings and any other agricultural producer or land management workshop where land management ideas and innovative concepts are discussed.

\section{Goal 4: Urban areas will protect ecological resources including water quality and quantity.}

Objective 4.1: New and existing urban development will be renovated or constructed in ways that protect ecological resources including wildlife habitat.

Action 4.1.1: Local government should implement the development and maintenance standards for water body protection as described in the California Stormwater Quality Association's (CASQA) Stormwater Best Management Practice (BMP) Municipal Handbook (2004).

Action 4.1.2: Local governments, landowners establishing access roads, and transportation authorities should implement the guidelines and standards described in Caltrans Storm Water Quality Construction Site Best Management Practices Manual (2003) and the National Pollutant Discharge Elimination System (NPDES) that have specific requirements for construction projects. 


\subsection{Other Potential Conservation Tools}

Ultimately, the Conservancy should also be adaptable to opportunities within the region that may not directly follow the plan. Proper review and processing of these projects should be utilized. The Conservancy should utilize conservation easements where feasible, but may utilize other conservation tools as appropriate.

\section{Other conservation acquisition tools}

There are several techniques that land trusts and agencies have employed to protect land. Some of these methods include:

- Donations or bargain sales

- Options and rights-of-firstrefusal

- Leases and management agreements

- Remainder interests

- Undivided interests

- Dedications and preacquisitions
- Conservation investors or buyers

- Limited or joint venture development

- Installment sales

- Purchase (or donation) and leaseback

- Donation by will

\section{Ranch lease acquisition program}

Another project idea would be to purchase an available priority rangeland through the fee-title process. The property can be used to model sustainable management practices, provide a study area for students to learn rangeland management, livestock management, and study ecosystem and agribusiness. Land can be leased to ranchers at reduced lease rates to 
incorporate help with land management and implementing best management practices.

Educational programs can be facilitated on the property.

\section{Conservation Buyer Program}

The Jackson Hole Land Trust and other partnering land trusts have successfully worked with local realtors to advertise and find conservation minded land and homebuyers for priority properties. The scale of a project can be larger than the watershed scale and can involve a number of partners. For more information on the Conservation Buyers Program visit: http://www.northernrockyranches.com/ 


\subsection{Evaluation of Success}

Protection of important farmland and ecological resources is essential to the success of this plan—protection and enhancement of riparian, stream banks and waterways that ensure quality habitat for in stream and riparian wildlife species, stream morphology and water quality for downstream users. Evaluation of projects is an important step to understanding project success, failure, and making appropriate changes to ensure success of the plan/project. Individual projects will generally be evaluated on their own based on their objectives. Followups with landowners to maintain partnerships and ensure long-range evaluation of conservation agreements, changes to ecosystems, etc. is an important part of evaluating and ensuring success. Ultimately, successful achievement of the goals and objectives described in Chapter 5 and landscape evaluation described in Chapter 4 are the baseline measures of success. However initial site visits to specific properties and targeted resource conservation objectives agreed upon by all parties in any conservation agreement will provide baseline indicators for property specific evaluation.

The establishment of a landscape monitoring protocol is subject to the conservation indicators as directed by Action 1.1.6 in Chapter 5. Different properties will have unique characteristics that the landowner and the Conservancy consider important. Protection and enhancement projects established in any conservation agreement will be unique and require a monitoring protocol unique to the property and specific conservation indicators deemed important on each property. Indicators such as oak stand diversity and grassland quality (soil quality, forage production, etc) will remain fairly consistent from property to property and similar protocols can be applied to those indicators. Generally, site monitoring and aerial photography assessments can detect changes in ecosystem structure and function over time.

Water quality monitoring is a key indicator in determining the success of conservation programs in the watershed. The Salinas River has been listed as a medium priority impaired 
water body under section 303(d) of the Clean Water Act (Worcester et al.. 2000). Identified issues include nutrient, salinity, pesticide, chloride and sedimentation pollution caused primarily by agricultural operations, but also from highway runoff, construction, and channel erosion (Worcester et al.. 2000).

Previous water quality monitoring by the Central Coast Watershed Council and the California Regional Water Quality Control Board through its Central Coast Ambient Monitoring Program (CCAMP) focused efforts downstream of the Conservation Area as far south as Atascadero Creek under the Highway 41 Bridge. Impaired water bodies are slated for the establishment of TMDL protocols and regulation. As the threat of development and higher intensity agricultural uses increase in the region, more monitoring to the Upper Salinas Watershed will need to be performed in order to adapt to changing water quality conditions and ways to remedy outstanding issues. Therefore, additional water quality monitoring points within the Conservation Area, including in the upper tributaries should be established especially as land use in the region begins to change. The Pesticide Use Database can be utilized to help determine where to locate monitoring sites for pesticide inputs. Increased monitoring points coupled with more consistent monitoring can pinpoint more precise problem areas. The action items suggested in Chapter 5 were included in the plan to help maintain, reduce or minimize pollution inputs contributing to water quality degradation. Success should be assessed through consistent water quality evaluations. The Regional Water Quality Control Board utilizes a number of methods in their CCAMP assessments to determine water quality and includes Conventional water quality (CWQ), State Muscle Watch (SMW), Rapid Bioassessment (RBA), Sediment chemistry (SC) and Pre-dawn dissolved oxygen (DO) (Worcester et al.. 2000). Water quality objectives should be consistent with the Central Coast Basin Plan.

Site visits should ensure compliance with long-term conservation agreements. Organizational staff should collect baseline data on initial site visits and develop a protocol to 
monitor the quality and any other changes in ecosystem structure and function. Monitoring protocols will be specific to the terms of the long-term conservation agreement and indicators identified for conservation. Monitoring protocols and conservation indicators will reflect the goals and objectives identified in Chapter 5. 


\subsection{Statutory Framework}

Watershed scale conservation requires collaborative efforts from a number of federal, state and local agencies. Agencies and political districts that operate in the Upper Salinas Headwaters Conservation Area are described below.

\subsection{Political Districts}

\section{Congressional District}

Congressional District 22

Boundary: Covers most of Kern and San Luis Obispo Counties, and northeastern Los Angeles County.

Representative: Rep. Kevin McCarthy

Committees: Subcommittee on Capital Markets, Insurance, and Government-Sponsored

Enterprises; Subcommittee on Financial Institutions and Consumer Credit

Contact information.

Washington, D.C.

326 Cannon House Office Building

Washington D.C. 20515

Phone: (202) 225-2915

Atascadero, CA

5805 Capistrano Avenue, Suite C

Atascadero, CA 93422

Phone: (805) 461-1034 
Bakersfield District Office

4100 Empire Drive, Suite 150

Bakersfield, CA 93309

Phone: (661) 327-3611

\section{State Senate District}

Senate District 15

Boundary: Coastal California stretching from southern coastal Santa Barbara County to Santa

Cruz and covers all of San Luis Obispo County.

Representative: Senator Sam Blakeslee

Sacramento, CA

State Capitol, Room 4070

Sacramento, CA 95814

Phone: (916) 651-4015

San Luis Obispo, CA

605 Santa Rosa Street, Suite B

San Luis Obispo, CA 93401

Phone: (805) 549-3779 


\section{Assembly District}

State Assembly District 33

Boundaries: Includes all of San Luis Obispo County and western Santa Barbara County from Santa Maria to Lompoc.

Representative: Katcho Achadjian

Committees: Committee on Arts, Entertainment, Sports, Tourism, and Internet Media;

Committee on Banking and Finance; Committee on Higher Education; Committee on

Transportation; Joint Committee on the Arts; Joints Committee on Fairs, Allocation, and

Classification; Select Committee on Aerospace; Select Committee on California-Mexico Bi-

national Affairs; Select Committee on State Hospital Safety; Select Committee on Wine; Select

Committee on the Renewable Energy Economy in Rural California; Joint Legislative Committee on Emergency Management.

San Luis Obispo, CA

1150 Osos Street

Suite 207

San Luis Obispo, CA 93401

Phone: (805) 549-3381

Sacramento, CA

P.O. Box 942849

Room 2016

Sacramento, CA

Phone: (916) 319-2033 


\subsection{Federal Regulatory Agencies}

\section{U.S. Army Corps of Engineers (USACE)}

The Upper Salinas Watershed within the Conservation Area is within the South Pacific Division of the Los Angeles District of the US Army Corps of Engineers (USACE). The Army Corps provides engineering services in water resources, environment, infrastructure, homeland security, and war fighting. Through their Civil Works program, they provide flood protection, coastal protection, navigable waters and ports, water supply, as well as recreational opportunities. They are also responsible for programs such as: Ecosystem Restoration, Environmental Stewardship, EPA Superfund, Abandoned Mine Lands, and Regulatory to list a few. USACE regulates discharge of dredge or fill material in coastal and inland waters and wetlands, construction and dredging in navigable waters, and the transport and disposal of dredged materials into ocean waters. USACE wetland related regulatory mechanisms include:

- $\quad$ Clean Water Act, Section 404 (b)(1) Guideline

- Marine Protection, Research and Sanctuaries Act

- Endangered Species Act

- National Historic Preservation Act

- Coastal Zone Management Act

- National Environmental Policy Act

- Fish and Wildlife Coordination Act

Los Angeles District Regulatory Office: Ventura Field Office

2151 Alessandro Drive, Suite 110

Ventura, CA 93001

Phone: (805) 585-2140 


\section{U.S. Fish and Wildlife Service (USFWS)}

The Upper Salinas Watershed within the Conservation Area is located in the Pacific Region (Region 1) of the USFWS. The USFWS conserves, protects, and enhances fish, wildlife, plants, and their habitats for the continuing benefit of the public. The USFWS consults with the USACE to ensure permitted projects protect fish and wildlife, and assess potential impacts to restrict potentially harmful activities. They are also in charge of enforcing federal laws that protect wildlife, such as the Endangered Species Act.

Local Office: Ventura Fish and Wildlife Office

2493 Portola Road, Suite B

Ventura, CA 93003

Phone: (805) 644-1766

\section{National Oceanic and Atmospheric Administration (NOAA) Fisheries Service}

The Upper Salinas Watershed is located within the Southwest Region of the NOAA Fisheries Service. NOAA Fisheries Service is a division of the Department of Commerce that promotes sustainable fisheries, recovery of protected species, and the health of coastal marine habitats in the United States. NOAA's National Marine Fisheries Service works with communities on fishery management issues and to prevent lost economic potential due to overfishing, declining species and degraded habitats. Like the USFWS, NOAA Fisheries Service also works with other federal agencies to see that projects permitted comply with various federal regulations regarding fisheries and protected species. 
Local Office: Long Beach

National Marine Fisheries Service

501 West Ocean Blvd.

Long Beach, CA 90802-4213

Phone: (562) 980-4000

\section{U.S. Environmental Protection Agency (USEPA)}

The Upper Salinas Watershed is located in the Pacific Southwest, Region 9, of the USEPA.

EPA is primarily responsible for protecting human health and safeguarding the natural environment in the United States. They regulate environmental hazards, such as air and water pollution, solid waste disposal, radiation and pesticides. The EPA also coordinates and supports research and pollution mitigation activities.

Headquarters Office:

US EPA Region 9

75 Hawthorne Street

San Francisco, CA 94105

Phone: (866) EPA WEST

\subsection{State Regulatory Agencies}

\section{California Department of Fish and Game (CDFG)}

The Conservation Area lies within the CDFG's Region 4, Central Region, serving Fresno, Kern, Kings, Madera, Mariposa, Merced, Monterey, San Benito, San Luis Obispo, Stanislaus, Tulare and Tuolumne counties. The local regional office is in Yountville, Ca, but local CDFG employees have satellite offices in San Luis Obispo. 
The CDFG conserves, protects, and manages the state's fish, wildlife, and native plant resources. Projects that impact a river, stream, or lake must be regulated by CDFG. If the Department determines the project may alter fish and wildlife resources, then a Lake or Streambed Alteration Agreement is required. The principal enforcement mechanism for CDFG is the California Fish and Game Code, Section 1600.

Central Region Headquarters Office:

1234 E. Shaw Avenue

Fresno, CA 93710

Phone: (559) 243-4005 ext. 151

\section{Regional Water Quality Control Board (Regional Boards)}

The State Water Resources Control Board has nine Regional Boards designed to develop and enforce water quality objectives. The Conservation Area lies within the Central Coast Region (3) of the Regional Board; they develop "basin plans" for their hydrologic area, monitor water quality, govern requirements, issue waste discharge permits, and identify and take enforcement action against violators.

Their principle regulatory mechanism comes from the federal Clean Water Act (CWA), which is driven in California by the Porter-Cologne Water Quality Control Act of 1970. As part of their responsibilities, the RWQCB maintains the State's 303(d) list of impaired water bodies, which require the Regional Board to prepare studies and remediation plans to bring water bodies' water quality to state standards. In addition, the RWQCB works with the Army Corps of Engineers to issue compliance documents for Section 401 of the Clean Water Act. 
Regional Office:

Central Coast Region (3)

895 Aerovista Place, Suite 101

San Luis Obispo, CA 93401

Phone: (805) 549-3147

\subsection{Non Regulatory Agencies}

\section{Natural Resources Conservation Service (NRCS)}

The NRCS assists landowners with conservation planning that benefits soil, water, air, plants, and animals, resulting in healthy ecosystems and productive lands. NRCS works locally, positioned in USDA Service Centers in nearly every county in the nation.

Local Service Center:

Templeton Service Center

65 South Main St., Ste. 106

Templeton, CA 93465-8703

Phone: (805) 434-0396

\section{Resources Conservation District (RCD)}

There are several Resource Conservation Districts in California. They are locally governed agencies established under the county's Local Agency Formation Committee (LAFCO). The $\mathrm{RCD}$ provides soil and water conservation information and assistance to private landowners, such as farmers and ranchers. They are also a growing component of conservation efforts, participating in watershed outreach and planning organizations, as well as implementing projects on private and public lands. RCD provides a full range of technical expertise and 
assistance to cities, counties, organizations, landowners, contractors and farmers to improve water quality, reduce erosion, and restore wildlife habitat. The RCD often approves grading permits for agricultural grading under authority from the County of San Luis Obispo. The Upper Salinas-Las Tablas Resource Conservation District covers two-thirds of San Luis Obispo County north to about one-tenth of Monterey County in the southeast.

Upper Salinas-Las Tablas Resources Conservation District

65 South Main St., Ste. 107

Templeton, CA 93465

Phone: (805) 434-0396 ext. 5

\section{San Luis Obispo County Farm Bureau}

The San Luis Obispo Farm Bureau preserves farmland and increases agricultural awareness throughout the county. North Coast Farm Center is the district representing Upper Salinas Watershed farmers.

651 Tank Farm Road

San Luis Obispo, CA 93401

(805) 543-3654 


\section{Central Coast Salmon Enhancement (CCSE)}

The CCSE is dedicated to the enhancement and restoration of the Central Coast salmon fishery and local creeks. CCSE is also devoted to educating the community on the ecology and economy of these resources.

229 Stanley Ave.

Arroyo Grande, CA 933420

(805) 473-8221

\subsection{Local Government}

\section{County of San Luis Obispo Planning and Building}

The County of San Luis Obispo Planning and Building Department provides public resources for countywide planning and development. The Planning and Building Department provides land use and development permits, building permits, code enforcement, zoning and maps, longrange community planning and other services.

Office:

Department of Planning and Building

County Government Center

San Luis Obispo, CA 93408

Phone: (805) 781-5600 


\section{San Luis Obispo County Fire Department/Cal Fire}

La Panza Fire Station is in operation each summer during a declared fire season. La Panza sits near the northern edge of Los Padres National Forest, and periodically responds to incidents in or near the forest.

\section{Station 41, La Panza Fire Station}

5398 Pozo Road

Santa Margarita, CA 93453

(805) $438-5460$

\section{Parkhill Fire Station $\mathbf{4 0}$}

Provides cooperative fire protection from both Cal Fire and San Luis Obispo County Fire Department.located east of Santa Margarita; Station 40 houses two State Type III wildland fire engine, a County Type I fire engine and Type II water tender. Station 40 has a 'high severity' response area. This classification is due to the interface of homes and substantial brush. Parkhill firefighters respond automatic aid to most incidents in Santa Margarita, as well as incidents along Highway 101 between the Cuesta Grade and the City of Atascadero.

6140 Parkhill Road

Santa Margarita, CA 93453

Table 9.1 below is an example of some of the agencies, their jurisdictions and the legislation that grants them their regulatory authority. 
Permitting Agency

Level of Government

\begin{tabular}{|c|c|c|c|c|}
\hline Army Corps of Engineers & Federal & $\begin{array}{l}\text { Authorization required for any construction, grading, } \\
\text { dredging, etc in the nation's waterways, including } \\
\text { wetlands under the Federal Clean Water Act }\end{array}$ & Federal Endangered Species Act & $\begin{array}{l}\text { US Fish and Wildlife Service } \\
\text { National Marine Fisheries } \\
\text { Service }\end{array}$ \\
\hline $\begin{array}{l}\text { National Marine } \\
\text { Fisheries Service (NOAA) }\end{array}$ & Federal & $\begin{array}{l}\text { Endangered Species Act jurisdication of marine } \\
\text { resources, including anadromous fish species such as } \\
\text { stealhead trout, ESA permitting maybe required for any } \\
\text { instream construction or improvements. }\end{array}$ & $\begin{array}{l}\text { Federal Clean Water Act } \\
\text { Porter-Cologne Act, California } \\
\text { Water Code }\end{array}$ & $\begin{array}{l}\text { US Environmental } \\
\text { Protection Agency } \\
\text { US Army Corps of Engineers } \\
\text { State Water Resources } \\
\text { Control Board }\end{array}$ \\
\hline $\begin{array}{l}\text { US Fish and Wildlife } \\
\text { Service }\end{array}$ & Federal & $\begin{array}{l}\text { Endangered Species Act jurisdication of fish, wildlife } \\
\text { and plant resources ESA permitting i.e. take permits, }\end{array}$ & California Coastal Act & $\begin{array}{l}\text { California Coastal } \\
\text { Commission }\end{array}$ \\
\hline $\begin{array}{l}\text { Department of Fish and } \\
\text { Game }\end{array}$ & State & $\begin{array}{l}\text { Authority under the California's Endangered Species } \\
\text { Act, permitting is required if project/use affects State } \\
\text { listed species including take permits and Stream } \\
\text { Alteration Agreements }\end{array}$ & $\begin{array}{l}\text { Coastal Zone Act Reauthorization } \\
\text { Amendment Section } 6217\end{array}$ & $\begin{array}{l}\text { National Oceanic And } \\
\text { Atmospheric Administration } \\
\text { US Environmental } \\
\text { Protection Agency }\end{array}$ \\
\hline $\begin{array}{l}\text { Regional Water Quality } \\
\text { Control Board }\end{array}$ & State & $\begin{array}{l}\text { Provide regulatory oversight and planning to protect the } \\
\text { water quality of region specific waterways. Primary } \\
\text { planning document are the Basin Plans. }\end{array}$ & $\begin{array}{l}\text { Fish and Game Code Section } 1601 \\
\text { and } 1603 \\
\text { California Endangered Species Act }\end{array}$ & $\begin{array}{l}\text { California Department of } \\
\text { Fish and Game }\end{array}$ \\
\hline $\begin{array}{l}\text { Grading Ordinance } \\
\text { (Different Local } \\
\text { Departments) }\end{array}$ & Local & $\begin{array}{l}\text { Requires applicant to participate in a ministerial permit } \\
\text { process (sometimes discretionary) where each permit } \\
\text { application is evaluated to determine compliance with } \\
\text { the required standards. Grading permits are meant to } \\
\text { protect health; property; public welfare, avoid water } \\
\text { quality issues involcing hazardous materials, nutrients } \\
\text { or sediments caused by surface runoff on or across the } \\
\text { permit area; and to ensure that the use of the site is } \\
\text { consistent with the general plan, }\end{array}$ & $\begin{array}{l}\text { California Environmental Quality } \\
\text { Act }\end{array}$ & $\begin{array}{l}\text { Various state and local } \\
\text { agencies }\end{array}$ \\
\hline $\begin{array}{l}\text { City/County } \\
\text { Environmental Health } \\
\text { Department }\end{array}$ & Local & $\begin{array}{l}\text { Maybe involved if project has a potential to cause harm } \\
\text { to human health }\end{array}$ & $\begin{array}{l}\text { Erosion and Grading Ordinances, } \\
\text { Development Standards, Habitat } \\
\text { Conservation Plans, Local Coastal } \\
\text { Plans and other local permits }\end{array}$ & Local Government \\
\hline $\begin{array}{l}\text { City/County Planning } \\
\text { Department }\end{array}$ & Local & $\begin{array}{l}\text { Responsible for local planning regulations, general plan } \\
\text { compliance, project compliance with ordinances and } \\
\text { associated allowable uses. Project permits may be } \\
\text { required depending on project type and associated } \\
\text { ordinances. }\end{array}$ & \begin{tabular}{|l|} 
General Plan, land use \\
ordinances, Williamson Act \\
contracts, zoning regulations
\end{tabular} & $\begin{array}{l}\text { Various local/regional } \\
\text { government agencies }\end{array}$ \\
\hline
\end{tabular}

Table 9.1 Examples of some potential permit requirements and the responsible/permitting agencies
Regulation

Responsible Agency Service

State Water Resources

control Board

Commission

Oceanic And

US Environmental

California Department of

Various state and local

materials, nutrients

Erosion and Grading Ordinances, Plans and other local permits

General Plan, land use

Various local/regional

government agencies 


\subsection{Conclusion}

Protection of the Upper Salinas Headwaters Conservation Area is important because of the large open space/rangeland areas that sit nestled between two mountain ranges that make up the Los Padres National Forest. This pristine, relatively intact landscape contains important headwaters of the Salinas River, has an abundance of vegetative communities that support a variety of wildlife, and supports a rich culture of ranching that has been in the area for hundreds of years.

However there is an increasing development pressure within the Conservation Area from the City of Atascadero and planned urban growth primarily in the northwestern lands within the Conservation Area (Property Ten and Property Sixteen). A trend towards more intense agricultural uses puts further pressure on ground and surface water quality and supply as well as available habitat for wildlife. The relatively intact landscape condition and looming development pressure reinforces the need for conservation action within the Conservation Area.

Over fifty percent of the Conservation Area is county, state, and federal public land. Thirty percent of the private land is contained in the sixteen large properties identified in this plan. Therefore there is potential to protect upwards of seventy-five percent or more of the Conservation Area, creating a very large contiguous matrix of public and private protected land ensuring protection water quality and the lands that drain into the Salinas River, and protection of large areas of oak savannah habitat.

This plan provides background and offers recommendations for actions to protect landscape characteristics within the Conservation Area. Laying out a strategy for long-term conservation is developed on the determination of priorities, which are based on landscape characteristics that are important to the Conservancy, landowners, and organizational and agency partners. There are four primary conservation strategies to achieve the objectives outlined in this plan: 
1.) Conservation policy and planning framework

2.) Conservation agreements (easements and acquisitions)

3.) Land management Best Management Practices

4.) Restoration (upland, riparian and stream projects)

While conservation prioritization can help lay the foundation for long-term strategy, the Conservancy should be open to opportunities for conservation not considered an initial priority. Consideration should be given based on a review of the particular property's landscape characteristics, cost of an agreement, etc. General areas for consideration should include a number of factors including proximity to other protected land, the presence of perennial streams/creeks, stream/river restoration need, and willingness of the landowner to work with the Conservancy.

Ultimately, implementing these strategies throughout the Conservation Area will take a network of partnerships. Private land conservation requires a big commitment from landowners. Many of the property owners of the lands identified in Figure A.13 in Appendix A already have plans for some level of permanent land conservation. These properties include:

- Property One

- Property Two has recently entered into a conservation easement agreement with the Conservancy.

- Property Ten

- Property Thirteen

- Property Fourteen

- Property Sixteen

The sensitive nature of making permanent property commitments is a careful process that should be built on trust. Through the interviews with several family ranchers in the region, 
all three families considered conservation and stewardship important. All of them also agreed that the Conservancy is well respected amongst many local ranchers regarding the handling of conservation easement contracts and the negotiation process. This is beneficial, particularly to landowners who might be apprehensive about negotiating complex agreements that will affect their land. Building trust and providing for a degree of flexibility in conservation agreements make landowners more willing to voluntarily enter into conservation agreements. The Conservancy should also note landowner concerns for burdensome regulatory constraints.

Bridging partnerships with landowners and agency personnel can have an impact on the streamlining required for permitting projects, helping landowners overcome regulatory obligations, and protecting particular landscape characteristics.

Working with landowners and other partners to implement the recommendations in this plan and any other actions deemed necessary to address specific landowner/landscape needs will help to achieve the Land Conservancy's mission of working collaboratively "to permanently protect and enhance lands having important scenic, agricultural, habitat and cultural values for the benefit of people and wildlife." 


\subsection{Literature Cited}

Aerial Information Systems (2009). San Luis Obispo County Vegetation Mapping Report: Photo Interpretative and Mapping Guidelines. County of San Luis Obispo, California.

Alexander, R.B., E.W. Boyer, R.A. Smith, G.E. Scharz, R.B. Moore. (2007). The Role of Headwater Streams in Downstream Water Quality. American Water Resources Association. 43:1 p.41-59

Allan, D.J. (2004). Landscapes and Riverscapes: The Influence of Land Use on Stream Ecosystems. Annual Review of Ecology, Evolution, and Systematics 35:257-284.

Amundsen III, Ole. (2007). Strategic Conservation Planning Student Guide for the Maine Coastal Protection Initiative.National Land Trust Alliance.

Barrios, A. (2000).Urbanization and Water Quality. The American Farmland Trust, DeKalb, Illinois, USA.

Bellows, Barbara. (2003). Managed Grazing in Riparian Areas: Livestock Systems Guide. Appropriate Technology Transfer for Rural Areas. National Sustainable Agriculture Information Service.

Brown, D.G., K M. Johnson, T.R. Loveland, and D.M. Theobald. 2005. Rural Land-use Trends in the Conterminous United States, 1950-2000. Ecological Applications 15 p.18511863.

Butler, L. (2002). Economic Survival of Western Ranching: Searching for Answers. Pp 195202. In: Knight, R.L., Gilgert, W.C. and Marston, E. Eds. Ranching West of the $100^{\text {th }}$ Meridian: Culture, Ecology, and Economics. Island Press. Washington, D.C.

California Coastal Commission (February 2001). Periodic Review of the San Luis Obispo LCP. Preliminary Report.

California Environmental Resources Evaluation System. Coastal Shrubs. Website accessed on January 15, 2011. Website accessed at: http://ceres.ca.gov/ceres/calweb/coastal/plants/scrub.html

California Department of Conservation. (2007). Important Farmland Mapping Categories and Soil Taxonomy Terms.

California Department of Finance. (2011). Interim County Population Projections. Demographic Research Unit. State of California. Sacramento, California.

California Department of Fish and Game. (April 7, 2000). Atascadero Creek Stream Survey. Technical Report. 
California Department of Forestry and Fire Protection. (2010). http://frap.fire.ca.gov/assessment2010.html California's Forests and Rangelands 2010 Assessment. Fire and Resource Protection Program.

California Polytechnic State University. Cal Poly Land: Coastal Scrub. Accessed on November 11, 2010. Website http://polyland.calpoly.edu/overview/archives/derome/scrub.html).

California Rangeland Conservation Coalition. E-Update. December 3, 2010.

California Rangeland Conservation Coalition.(2007). Focus Area Prioritization Map. Website: http://www.carangeland.org/focusarea.html.

California Rangeland Trust (2010).Accessed on 3/15/2011. Website: http://www.rangelandtrust.org.

Carter, H.O. et al.. (1989). Land in the Balance: Williamson Act, Costs, Benefits and Options (Part 1). Department of Conservation. University of California Press.

Cheadle Center for Biodiversity and Ecological Restoration. Accessed on February 3, 2011. Website: http://www.ccber.ucsb.edu/ecosystem/habitats/grassland/.

Chipping, D.H. (1987). The Geology of San Luis Obispo County: A Brief Description and Field Guide. California Polytechnic State University, San Luis Obispo.191 pp.

City of Atascadero.(2002). General Plan.

Congressional Budget Office. (2009). Federal Estate and Gift Taxes. Economic and Budget Issue Brief.

County of San Luis Obispo. (2003). Facts About the Land Conservation Act Properties.

County of San Luis Obispo (2010). [map] County of San Luis Obispo Vegetation Mapping Report GIS Vegetation Data.

Crawford, Multari, Clark and Mohr. (2000). Conserving the Landscapes of San Luis Obispo County. Published for The Nature Conservancy and the Land Conservancy of San Luis Obispo County.

Crim, J.F. 2007. Water quality Changes Across an Urban-Rural Land Use Gradient in streams of the West Georgia Piedmont. M.S. Thesis, Auburn Univeristy, Auburn, AL.

Daniel, John. (1986). California's Chumash Indians. Santa Barbara Museum of Natural History.

Department of Agriculture (2010). Annual Crop Report. San Luis Obispo County

Dosskey, M.G., M.J. Helmers, D.E. Eisenhauer, T.G. Franti, and K.D. Hoagland. (2002). Assessment of Concentrated Flow through Riparian Buffers. Journal of Soil and Water Conservation.Soil and Water Conservation Society. Vol 57:6 p336-343. 
Eagle Ranch, LLC. Accessed on March 18, 2011. Website: http://www.theeagleranch.com/. Last updated in 2008.

Fitzgerald, Richard T. Cross Creek: An Early Holocene/Millingstone Site. California State Water Project, Coast Branch Series, Paper Number 12. San Luis Obispo County Archaeological Society, San Luis Obispo, California. 2000.

Foster, Holly. Bridging the Urban-Rural Divide with Conservation Easements; Success Stories From California. California Rangeland Trust. Presentation at the Quivira Conference. New Mexico. January 14, 2006.

Freeman, M.C., Pringle, C.M. and Jackson, C.R. (2007).Hydrologic Connectivity and the Contribution of Stream Headwaters to Ecological Integrity at Regional Scales. Journal of the American Water Resources Association. American Water Resources Association. Vol 43, February no. 1.

Funk, D.J. and Adriana Morales (2002-03) Upper Salinas River and Tributaries Watershed Fisheries Report and Early Actions. Upper Salinas Tablas Resource Conservation District.(Report).Retrieved 2010-12-15.

General Accounting Office. Using Structured Interviewing Techniques. Program Evaluation and Methodology Division, Washington D.C., 1991

Greenwood, Roberta S. (1972). 9000 Years of Prehistory at Diablo Canyon, San Luis Obispo County, California. San Luis Obispo County Archaeological Society. Occasional Paper No. 7. San Luis Obispo, California.

Hansen, A.J., R.L. Knight, J.M. Marzluff, S. Powell, K. Brown, P.H. Gude, K. Jones. (2005). Effects of Exurban Development on Biodiversity: Partterns, Mechanisms, and Research Needs. Ecological Society of America. Ecological Applications, 15(6) pp. 1893-1905.

Hargrave, J. (1993). The Impact of a Federal Grazing Fee Increase on Land Use in El Dorado County, California. Master's Project. Energy and Resources Group, University of California. Berkeley, pp 68.

Heimlich, R.E., and W.D. Anderson. 2001. Development at the Urban Fringe and Beyond: Impacts on Agriculture and Rural Land. ERS Agricultural Economic Report No. 803.U.S. Government Printing Office, Washington, DC.

Hendrick,K.D. (2007) Our Way of Life: Identity, Landscape, and Conflict. Ph.D. Thesis. University of California. Riverside.

Holland, R.F. 1986. Preliminary Descriptions of the Terrestrial Natural Communities of California. State of California, The Resources Agency.

Holland, V. L. and David J. Keil. 1995. California Vegetation. Kendall/Hunt Publishing Company. Dubuque, lowa. 
Huntsinger, L.; M. Johnson; M. Stafford; and J. Fried. (May 2010) Hardwood Rangeland Landowners in California from 1985 to 2004: Production, Ecosystem Services and Permanence. Rangeland Ecology Management 63: pp. 324-334.

Interagency Workgroup on Wetland Restoration. (2003). An Introduction and User's Guide to Wetland Restoration, Creation, and Enhancement. National Oceanic and Atmospheric Administration, Environmental Protection Agency, Army Corps of Engineers, Fish and Wildlife Service, and Natural Resources Conservation Service.

Lambert, C.S. (2007). State of conservation report for the Land Conservancy of San Luis Obispo County : a land conservation GIS-based decision support model. Masters in City and Regional Planning Thesis.California Polytechnic State University.

Las Tablas-Upper Salinas Resource Conservation District. (2004). Upper Salinas River watershed Action Plan. Final Report to the State Water Resources Control Board.

Las Tablas-Upper Salinas Resource Conservation District. (2002). Watershed Fisheries Report and Early Actions: A Study of the Upper Salinas River and Tributaries. Report to the California Department of Fish and Game.

Lee, K.H., T.M. Isenhart, and R.C. Shultz. (2003). Sediment and Nutrient Removal in an Established Multi-Species Riparian Buffer. Journal of Soil and Water Conservation.Soil and Water Conservation Society.Vol 58:1-8

Liffmann, R.H.; L. Huntsinger and L.C. Forero. (2000). To Ranch or Not to Ranch: Home on the Urban Range. Journal of Range Management, Vol. 53, No. 4, pp. 362-370.

Maestas, J. D. (2007). U.S. Department of Agriculture, Natural Resources Conservation Service. Effects of Exurban Development on Wildlife and Plant Communities. Washington, DC.

Mayer, P.M., S.K. Reynolds, M.D. McCutchen, and T.J. Canfield.(2006). Riparian buffer width, vegetative cover, and nitrogen removal effectiveness: A review of current science and regulations. EPA/600/R-05/118.Cincinnati, OH, U.S. Environmental Protection Agency.

Myers, M.D. and M. Newman. (2007). The Qualitative Interview in IS Research: Examining the Craft Information and Organization. 17 (2007) 2-26.

National Marine Fisheries Service. 2005. Updated Status of Federally Listed ESUs of West Coast Salmon and Steelhead. U.S. Dept. CommerNOAA Tech. Memo. Report by T.P. Good, R.S. Waples, and P. Adams.

Natural Resource Conservation Service.(2011). Ecological and Interpretative Groups.National Soil Service Handbook Part 622.

Website:http://soils.usda.gov/technical/handbook/contents/part622.html.

The Nature Conservancy, The Land Conservancy of San Luis Obispo County and Crawford, Multari, Clark and Mohr (2000). "Conserving the Landscapes of San Luis Obispo County". 
Odell, E.A., D.M. Theobald, and R.L. Knight. 2003. Incorporating Ecology into Land Use Planning: The Songbirds' Case for Clustered Development. Journal of the American Planning Association 69(1):72-82.

Pires, M. (2004). Watershed protection for a world city: the case of New York. Land Use Policy 21 (2004) 161-175.

Postel, S.L. and B.H. Thompson Jr. (2005). Watershed protection: Capturing the benefits of nature's water supply services. Natural Resources Forum 29 (2005) 98-108.

Press, D. (2002). Saving Open Space: The Politics of Local Preservation in California. University of California Press. Book Source

The Rangeland Trust. Accessed November, 15 2010. Website: http://www.rangelandtrust.org/

Rincon Consultants, Inc. (2008). Final Environmental Impact Report for Santa Margarita Ranch Agicultural residential Cluster Subdivision Project and Future Development Program. State Clearinghouse No. 2004111112. Prepared for the County of San Luis Obispo Department of Planning and Building.

Roper, K.C. , E.B. Bertrando, M.E. Clark, R.L. McKim, D.R. Harro, M.H. Imwalle, B.V. Bertrando, C.A. Denardo, and B.A. Price. (1997). Testing and Evaluation Report for Segment 2 of the Chorro Valley Water Transmission Pipeline Project. Applied EarthWorks, Inc., Fresno, California. Submitted to Montgomery Watson, Walnut Creek, California, and U.S. ArmyCorps of Engineers, Los Angeles District.

Rosgen, D.L. (1994). Classification of Natural Rivers. Catena 22: 169-199

San Luis Obispo County.Accessed on 2/21/2011. Website: http://www.slocounty.ca.gov/planning/landconservation.htm

San Luis Obispo County. (May 2010). General Plan. Agriculture Element.

San Luis Obispo County. (October 2009). General Plan. Land Use Element.

San Luis Obispo County. (May 2010). General Plan. Conservation and Open Space Element

Sawyer, J. O., and T. Keeler-Wolf. 1995. A manual of California vegetation. California Native Plant Society. Sacramento, California.

SLO Datafinder.Retrieved January 7, 2011, Web site: http://lib.calpoly.edu:8080/gis/.

Smoot, J.L., T.F.Cuffney, and W.L. Bryant, Jr. (2004). Effects of urbanization on stream ecosystems: Proceedings of the 1st annual Stormwater Management Research Symposium, Stormwater Management Academy, Orland, Fl. October 12-13th., pp 127136. 
South Coast Wildlands (2010). California Essential Habitat Connectivity Project: A Strategy for Conserving a Connected California.

Stark, B. and K. Kettman,. (2010). Restoration Field Guide: A User-Friendly Guide for Restoration Techniques in Riparian Habitats. Land Conservancy of San Luis Obispo County. http://www.Icslo.org/pdfs/restoration/OSPR\%20Guide 2010.pdf

The Nature Conservancy and Environmental Systems Research Institute.(1994). Standardized National Vegetation Classification System. United States Geological Survey/National Parks Service Vegetation Mapping Program. United States Department of the Interior.

United States Census Bureau. (2011). Quickfacts: San Luis Obispo County. Website: http://quickfacts.census.gov/qfd/states/06/06079.html

United States Department of Agriculture. (2009). 2007 Census of Agriculture: California State and County Data. Volume 1 Geographic Series part 2. Washington, DC: U.S.

Webb, E.B. (1952). Indian Life at the Old Missions. W. F. Lewis, Los Angeles, pg. 93

Wesche, T.A.; C.M. Geortler and C.B. Frye. (1987). Contribution of Riparian Vegetation to Trout Cover in Small Streams. North American Journal of Fisheries Management. Vol. 7:1.

Worcester, K., Paradies, D., Adams, M., \& Berman, D. 2000. Salinas River Watershed Characterization Report 1999. Central Coast Ambient Monitoring Program, Central Coast Regional Water Quality Control Board. 
APPENDIX A Conservation Area GIS Maps

FIGURE A.1 Geologic formations

\section{Geologic Formations Within the Conservation Area}

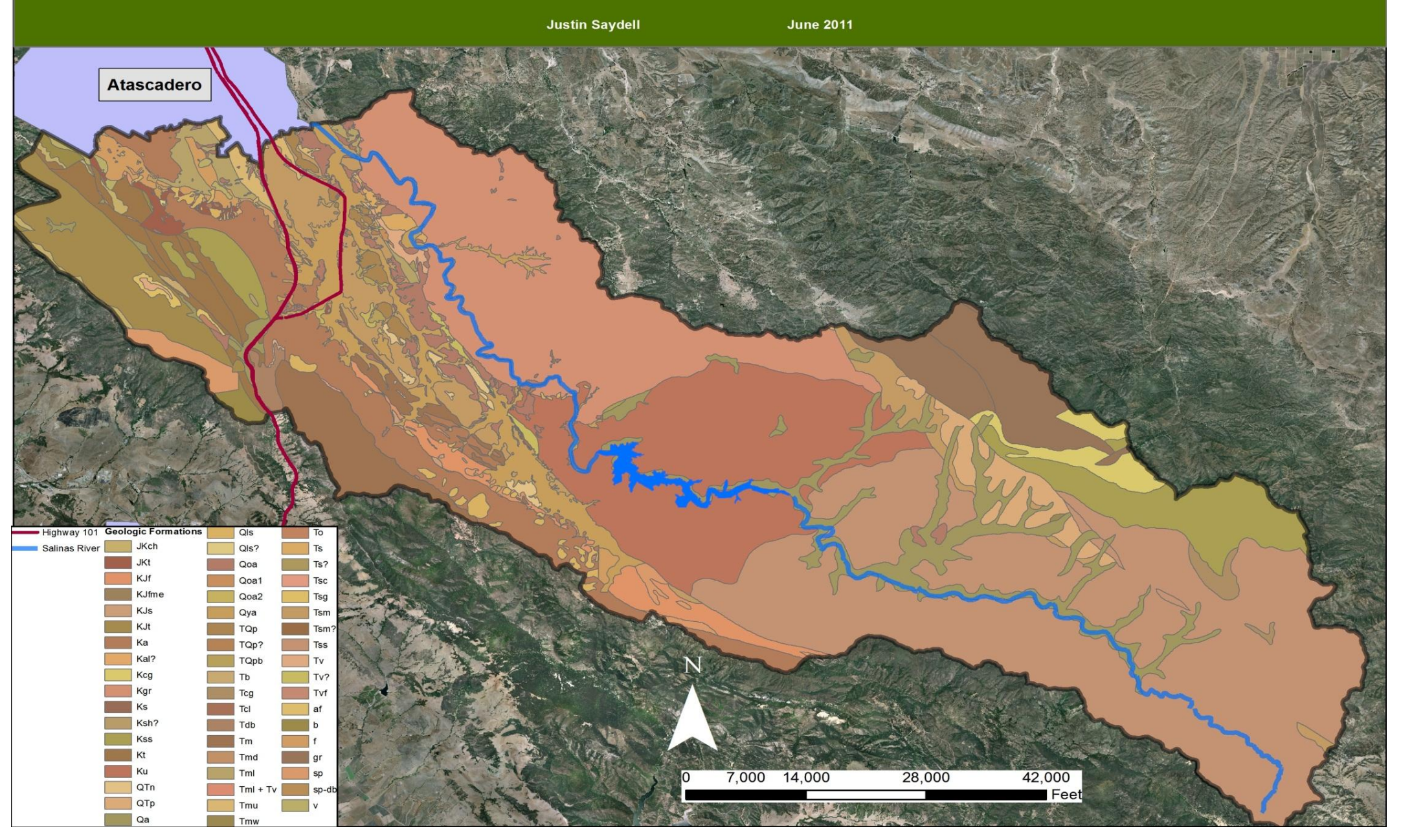


APPENDIX A Conservation Area GIS Maps

FIGURE A.2 Soil Types

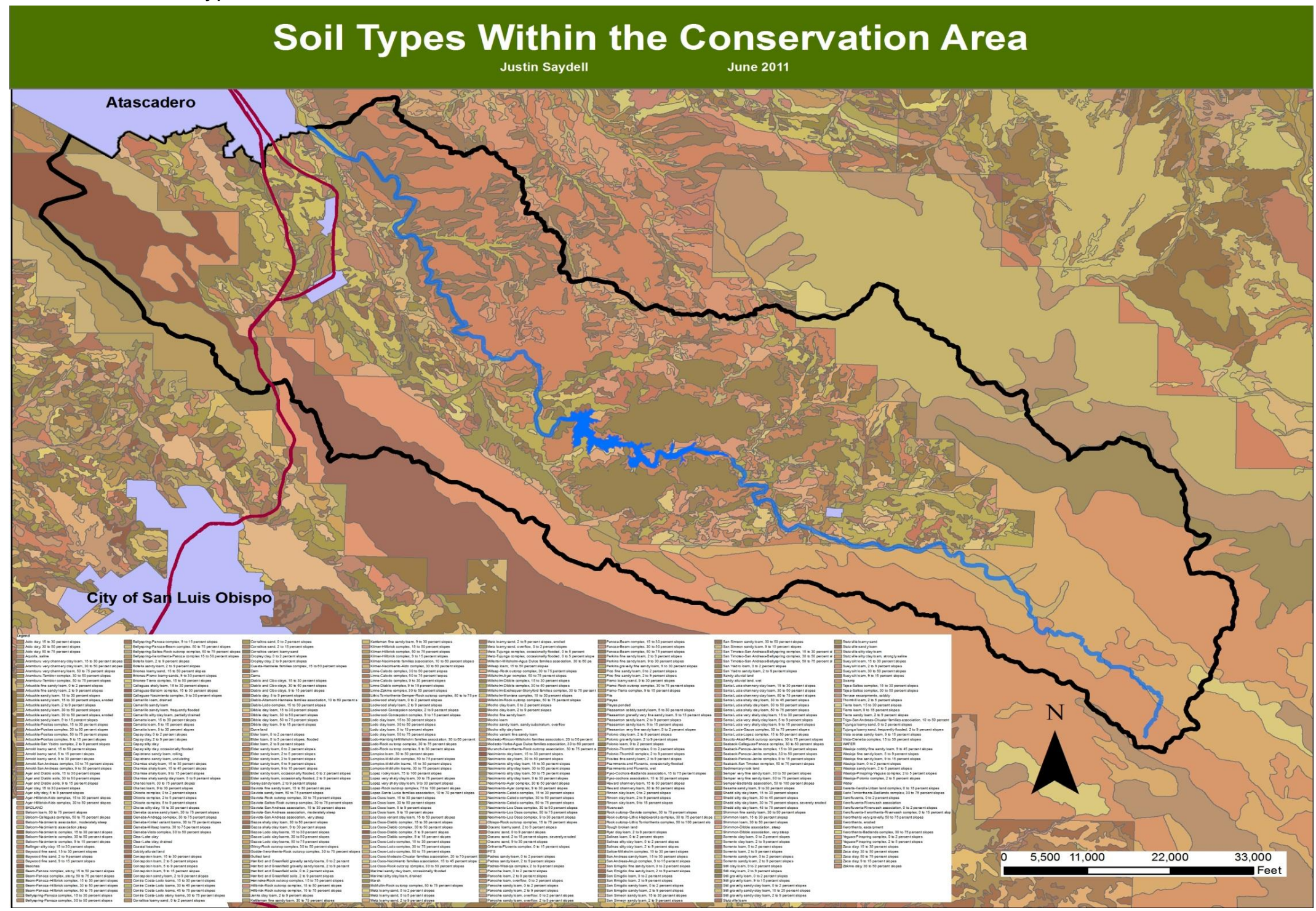


APPENDIX A Conservation Area GIS Maps

FIGURE A.3 Subwatersheds within the Conservation Area

\section{Subwatersheds Within the Conservation Area}

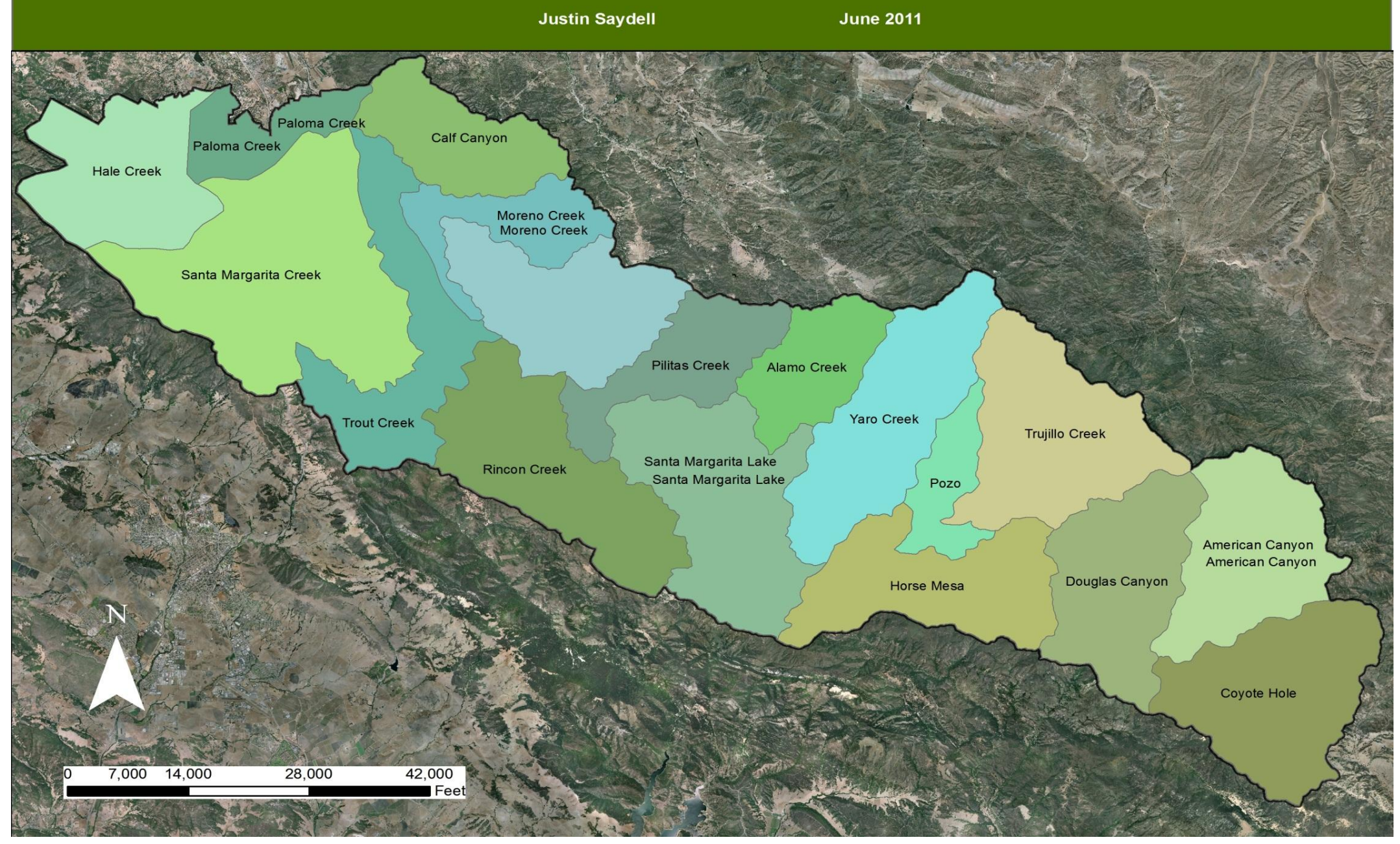




\section{Surface Water Public and Private Land}

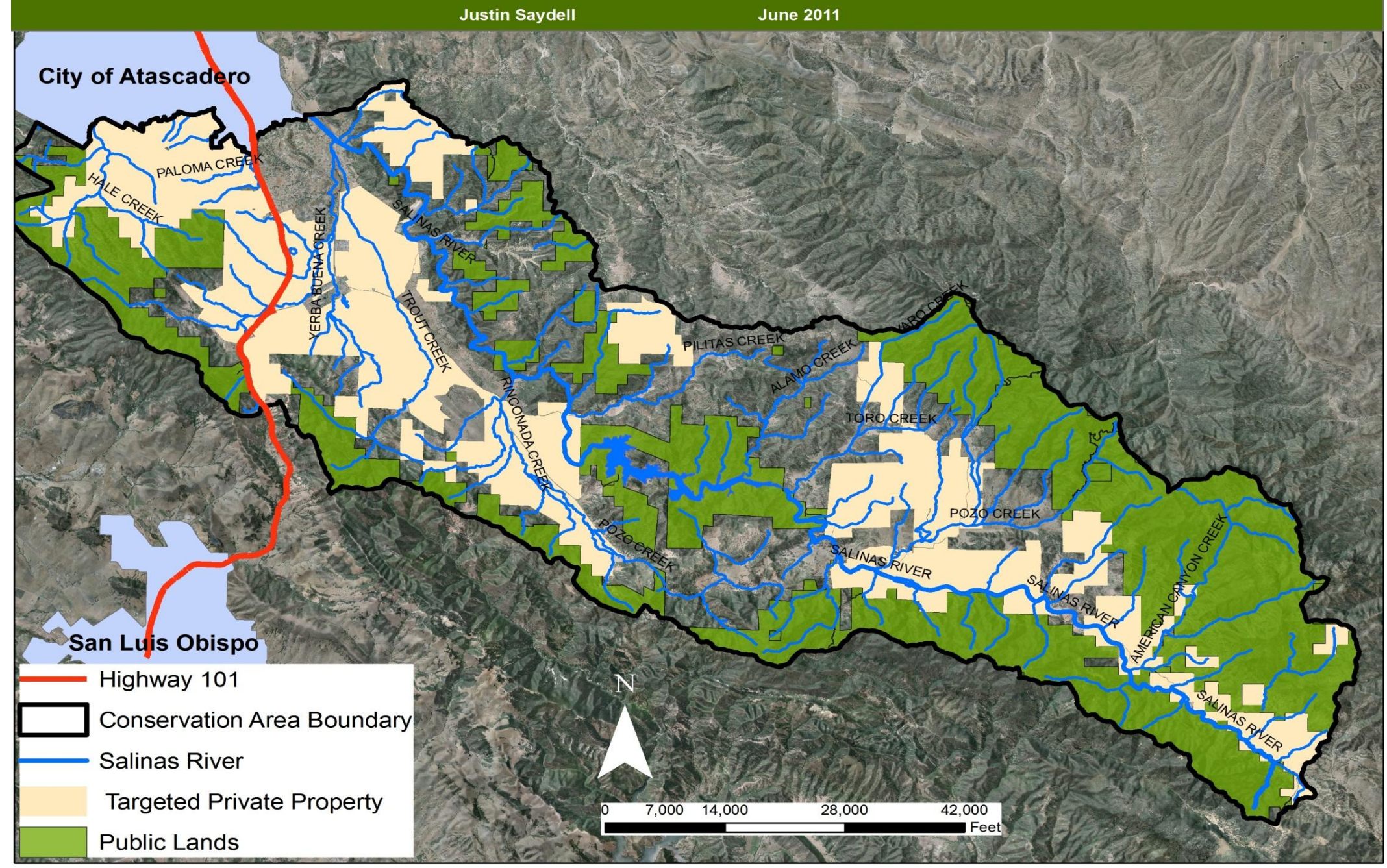


APPENDIX A Conservation Area GIS Maps

FIGURE A.5 Ground water Basins

Water Resources: Groundwater Basins and Drainages

Justin Saydell

June 2011

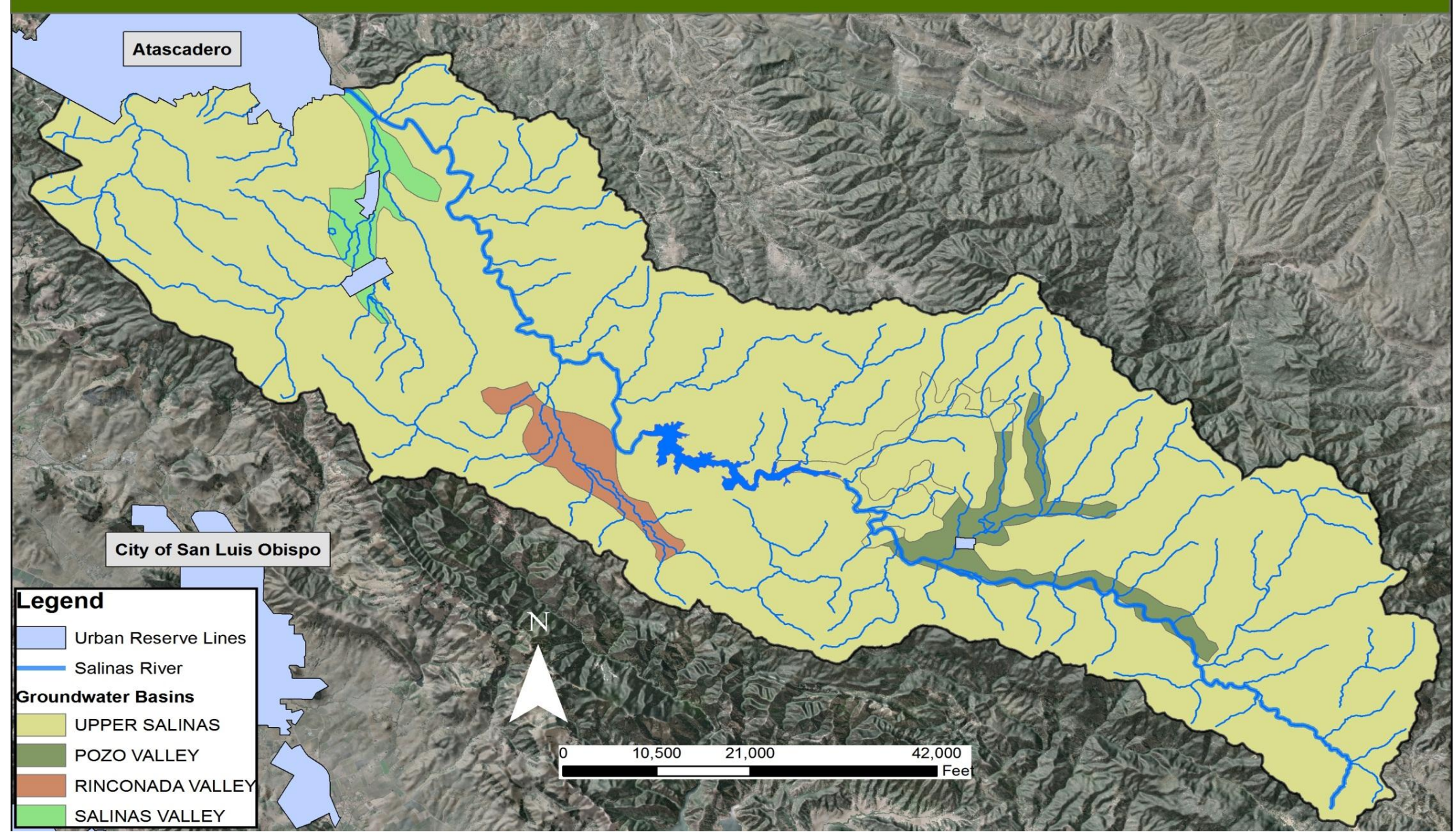


APPENDIX A Conservation Area GIS Maps

FIGURE A.6 Vegetation Types

\section{Vegetation Categories within the Conservation Area}

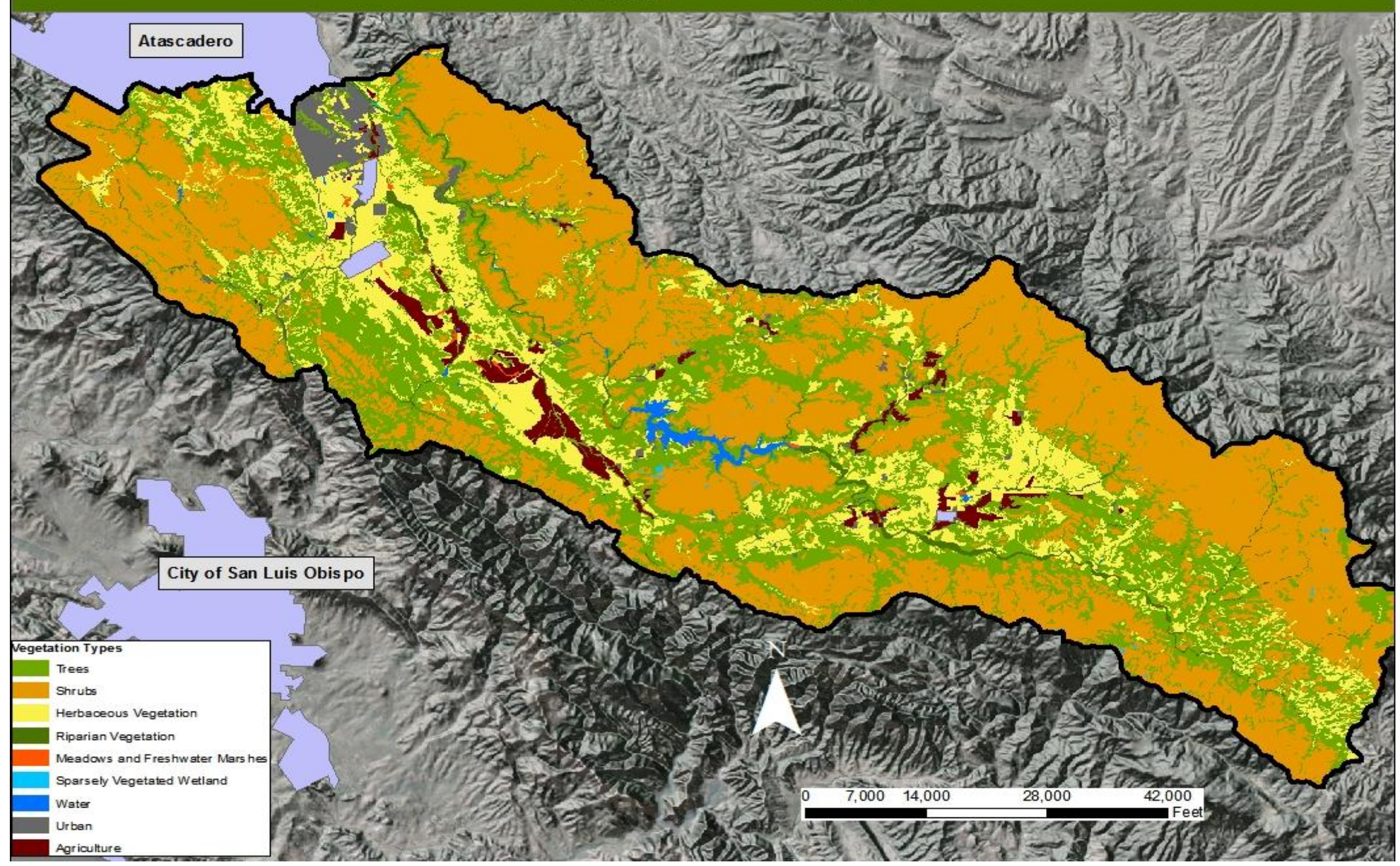


APPENDIX A Conservation Area GIS Maps

FIGURE A.7 Blue, Valley and Canyon Live Oak Stands

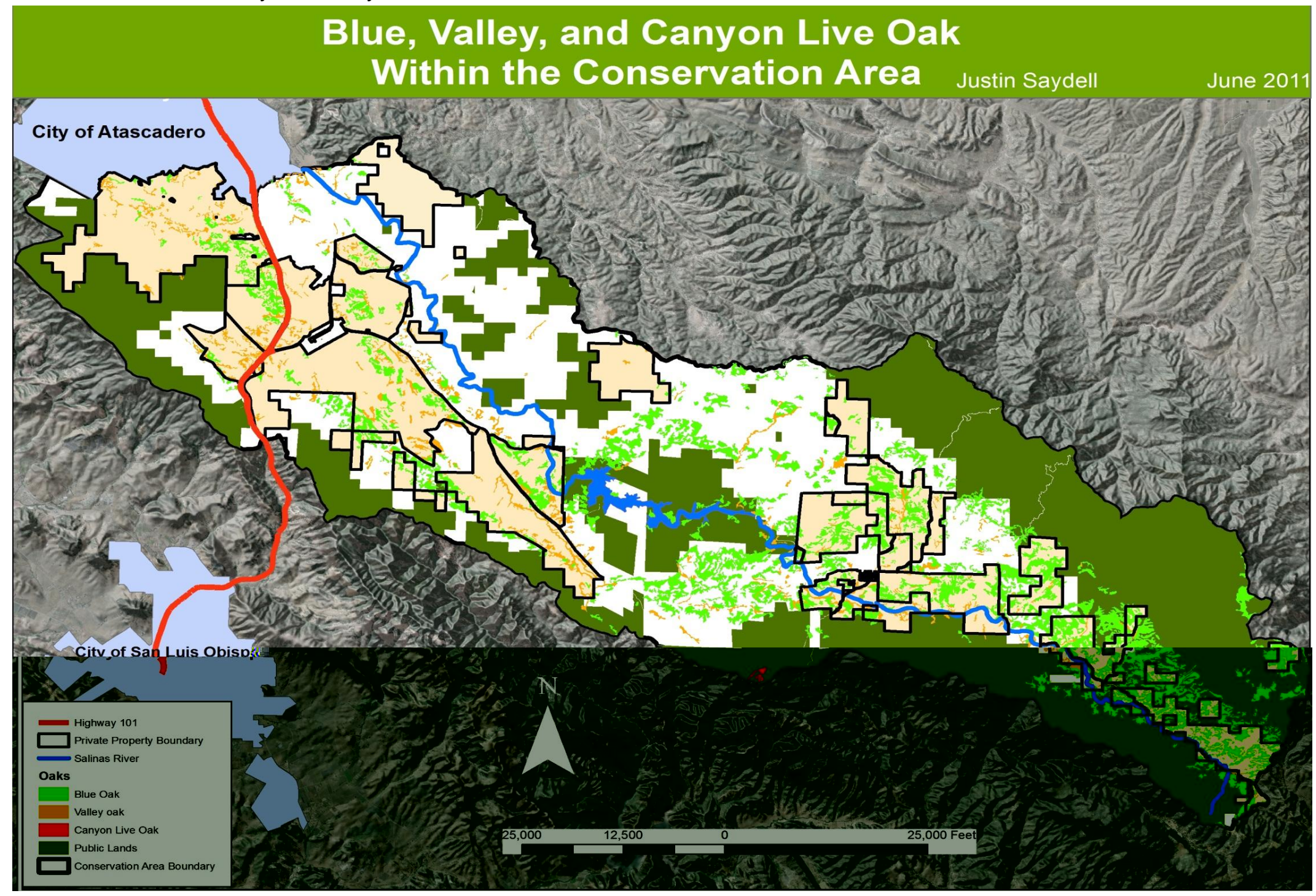


APPENDIX A Conservation Area GIS Maps

FIGURE A.8 Oak and Mixed Hardwood Stands

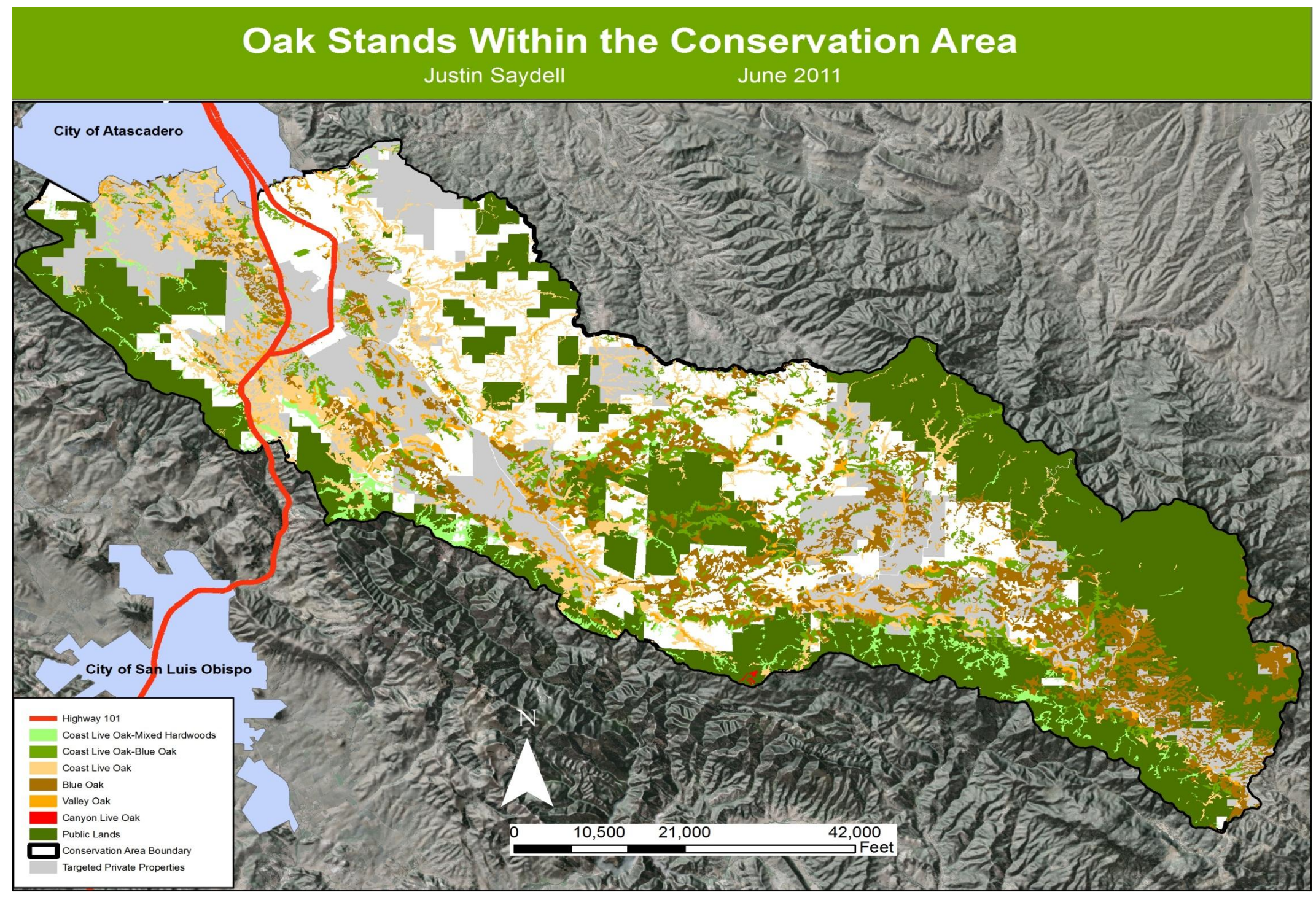


FIGURE A.9 Riparian, Marsh and Wetland Areas

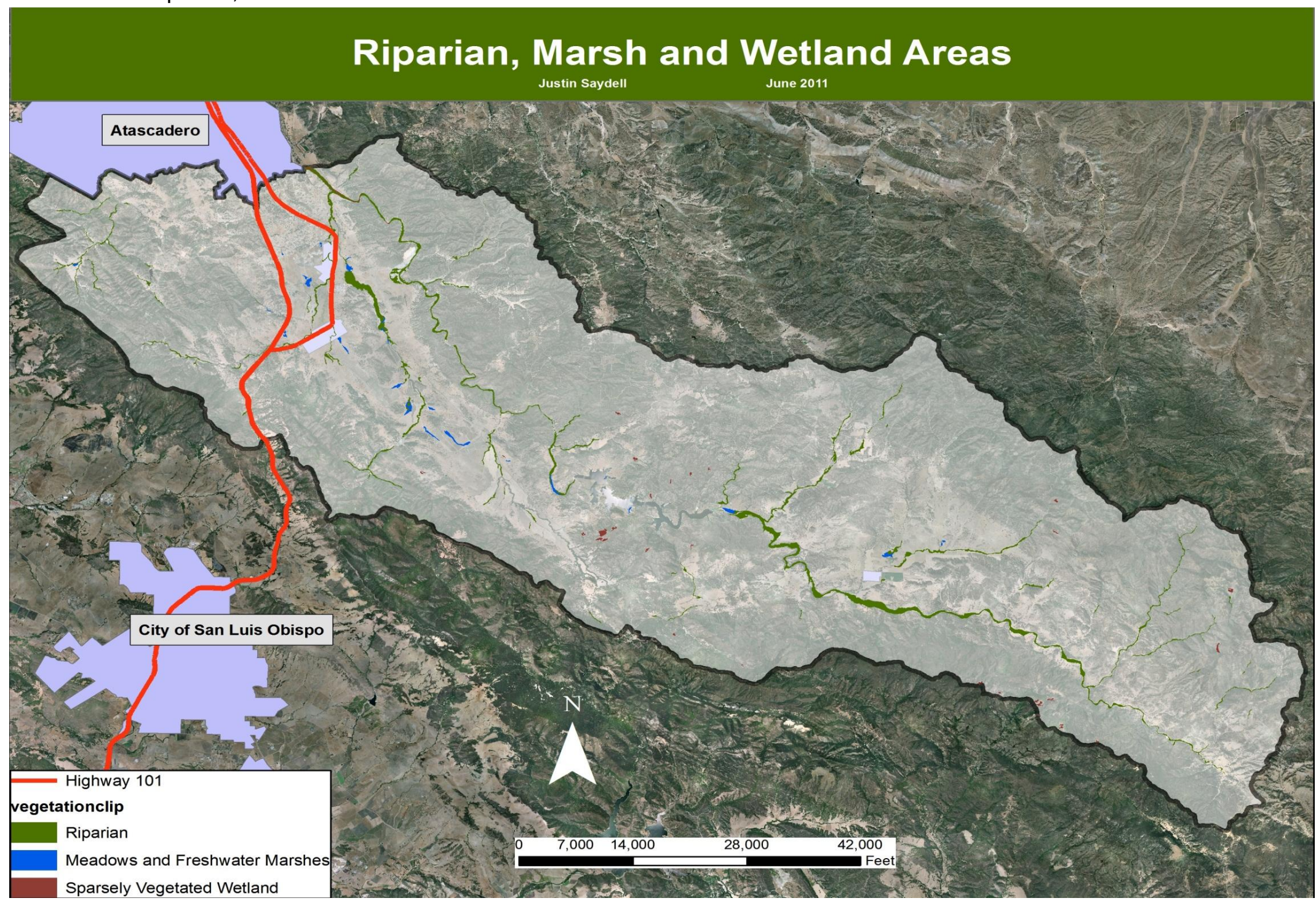


APPENDIX A Conservation Area GIS Maps

FIGURE A.10 Land Use Designations

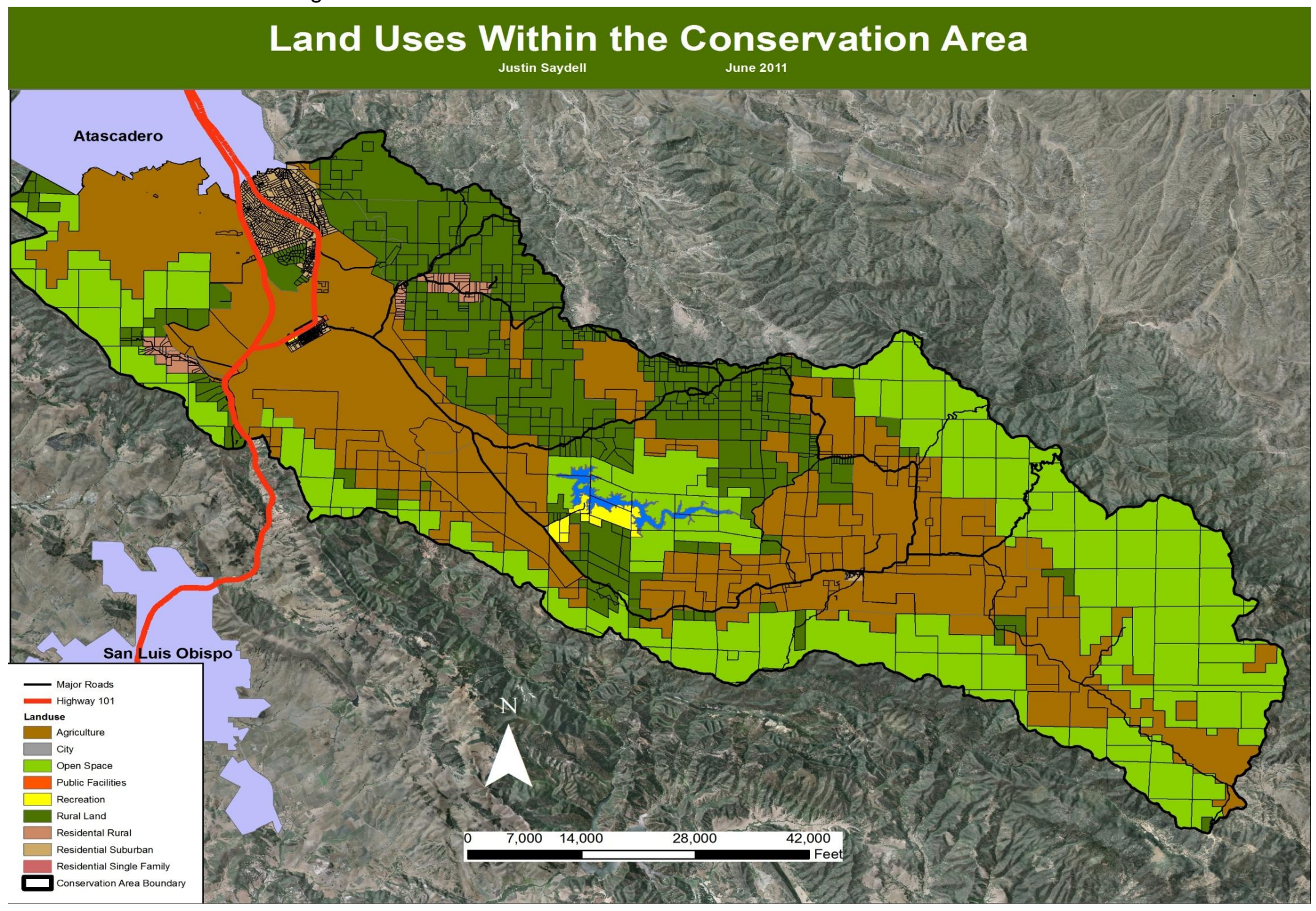


FIGURE A.11 Tracts that make up the largest properties in the Conservation Area

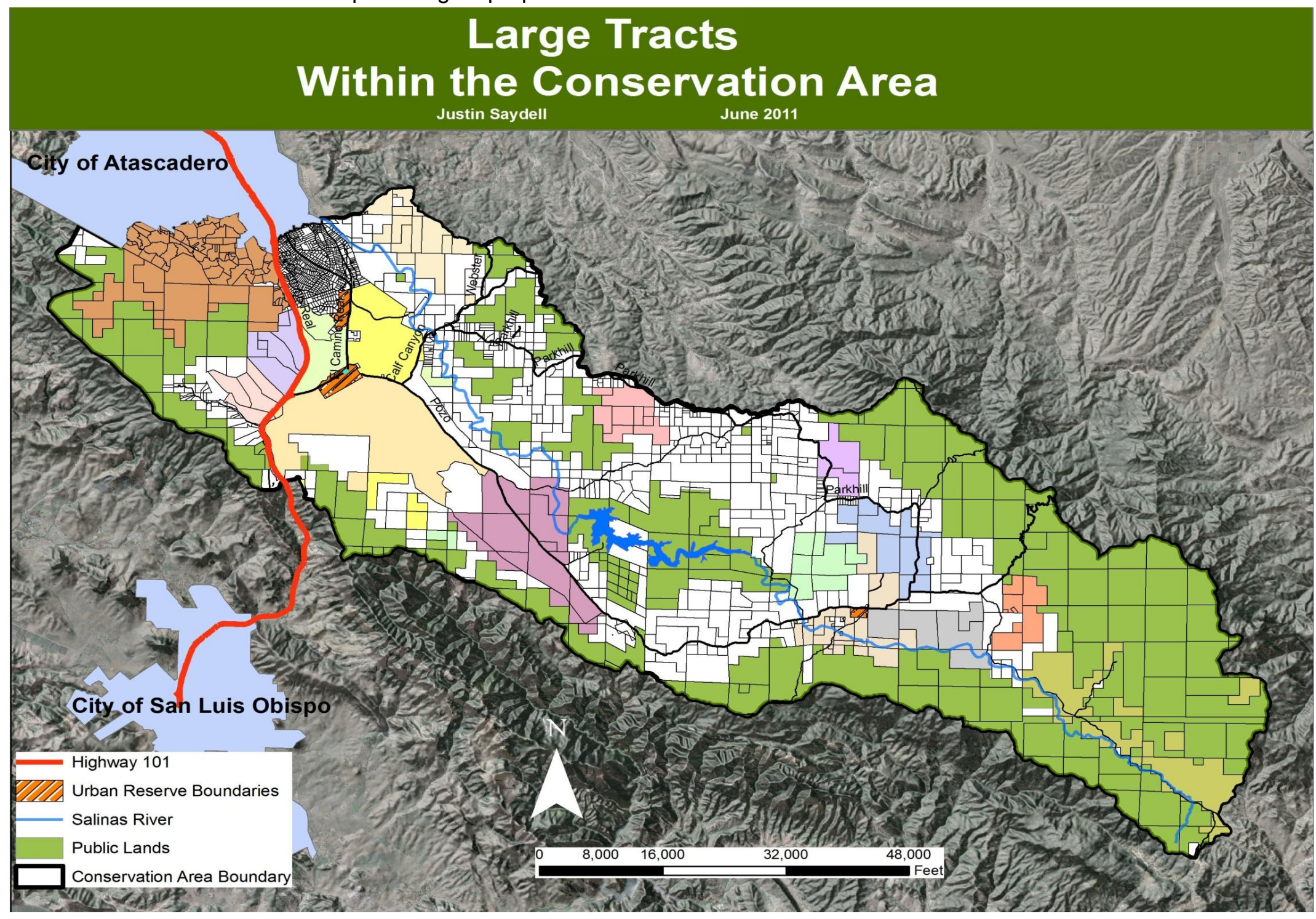


FIGURE A.12 Existing Protected Lands

\section{Protected Lands Within the Conservation Area Justin Saydell \\ June 2011}

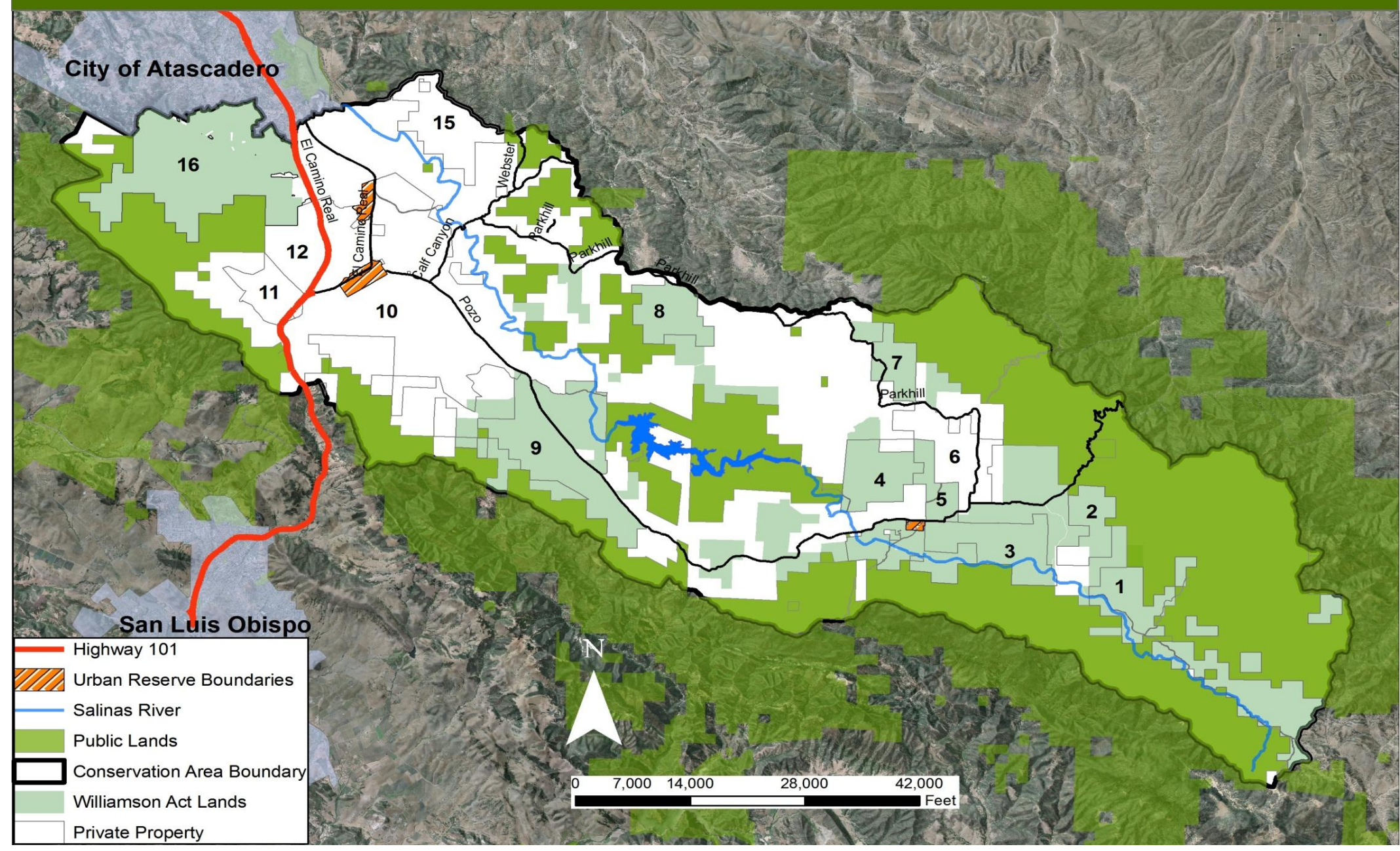


FIGURE A.13 Large Properties within the Conservation Area

\section{Large Properties within the Conservation Area}

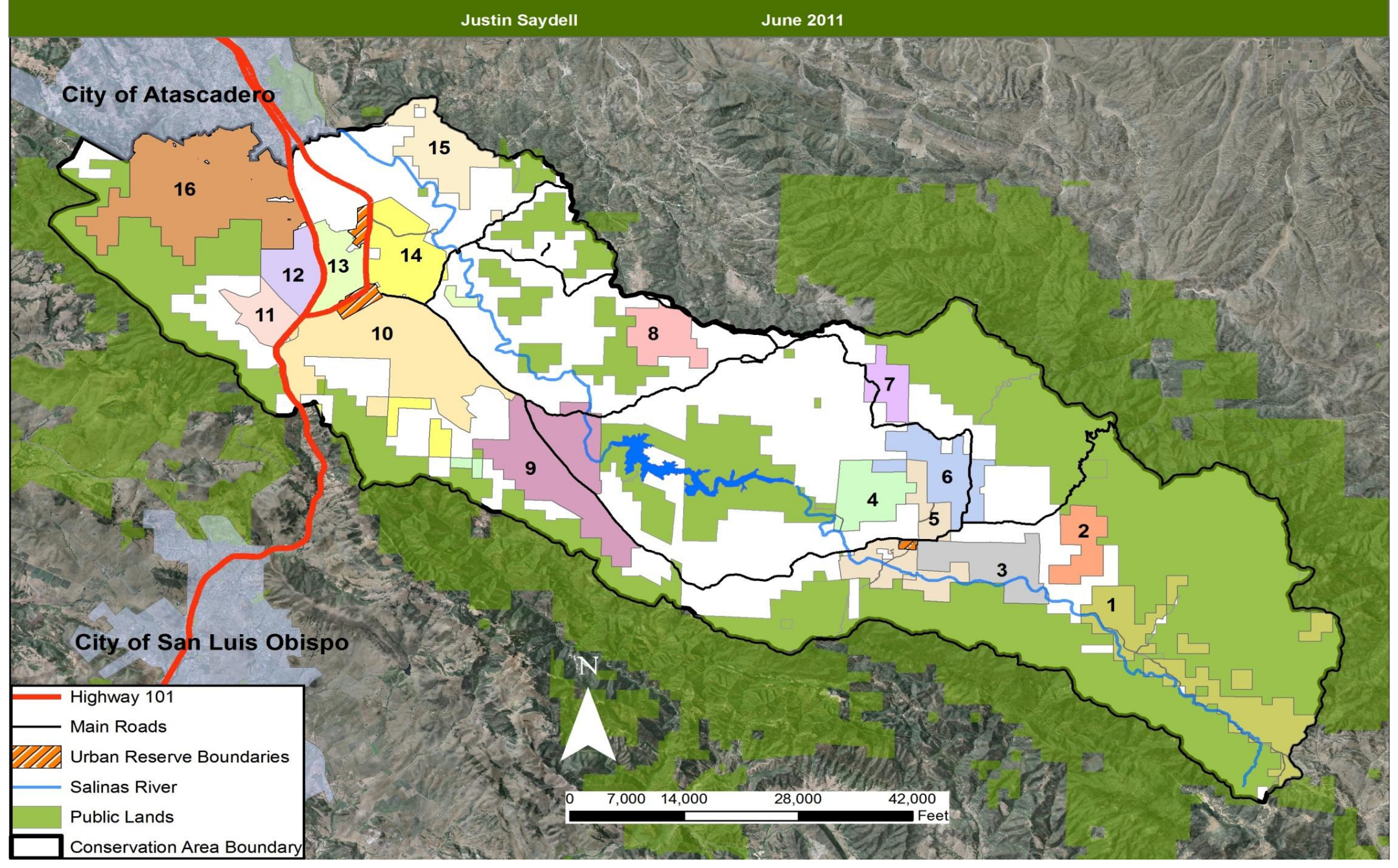


FIGURE A.14 Existing Rural, Urban and Agricultural Development

\section{Existing and Potential Development within the Conservation Area}

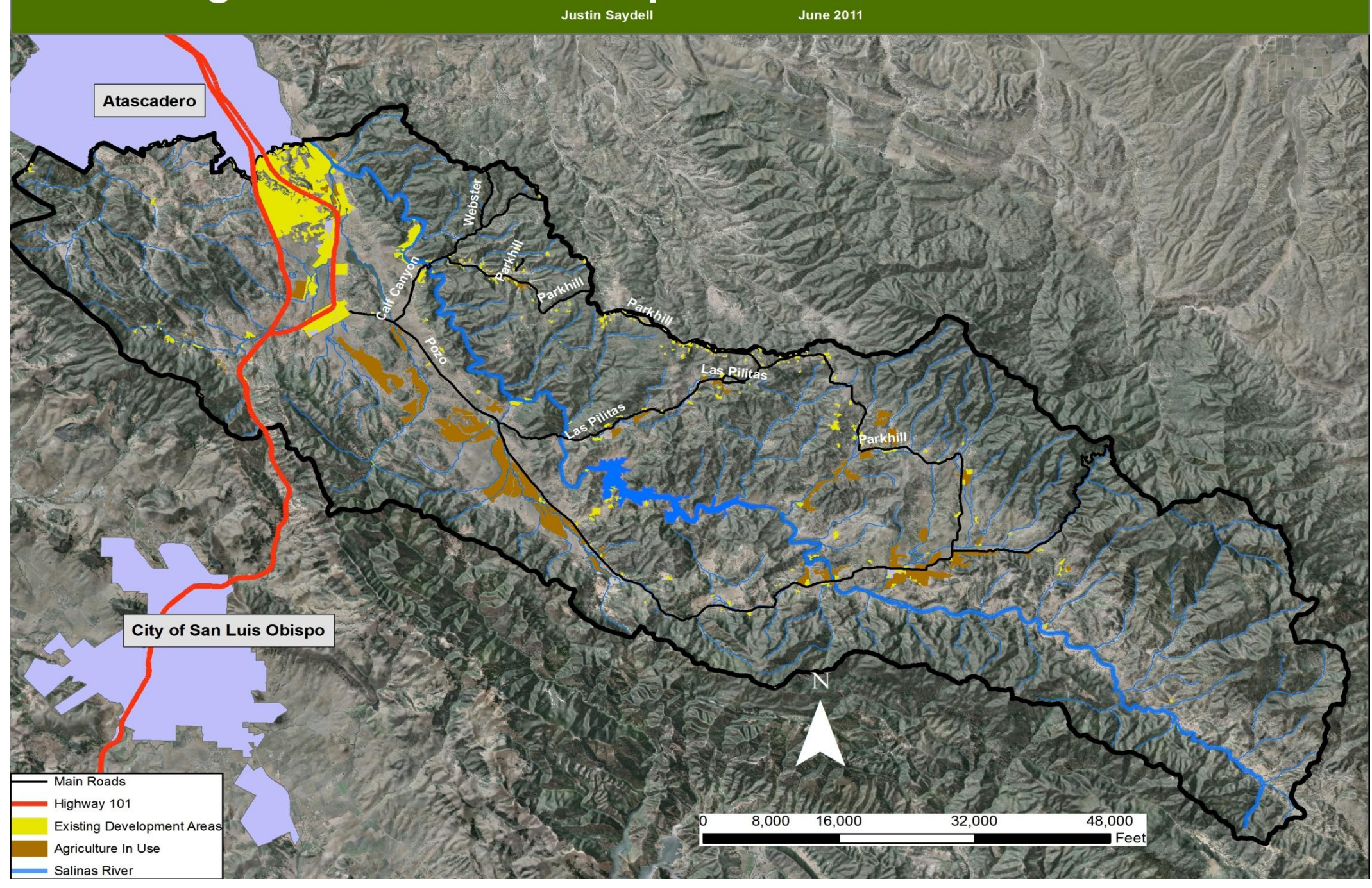


APPENDIX A Conservation Area GIS Maps

FIGURE A.15 Herbaceous Vegetation

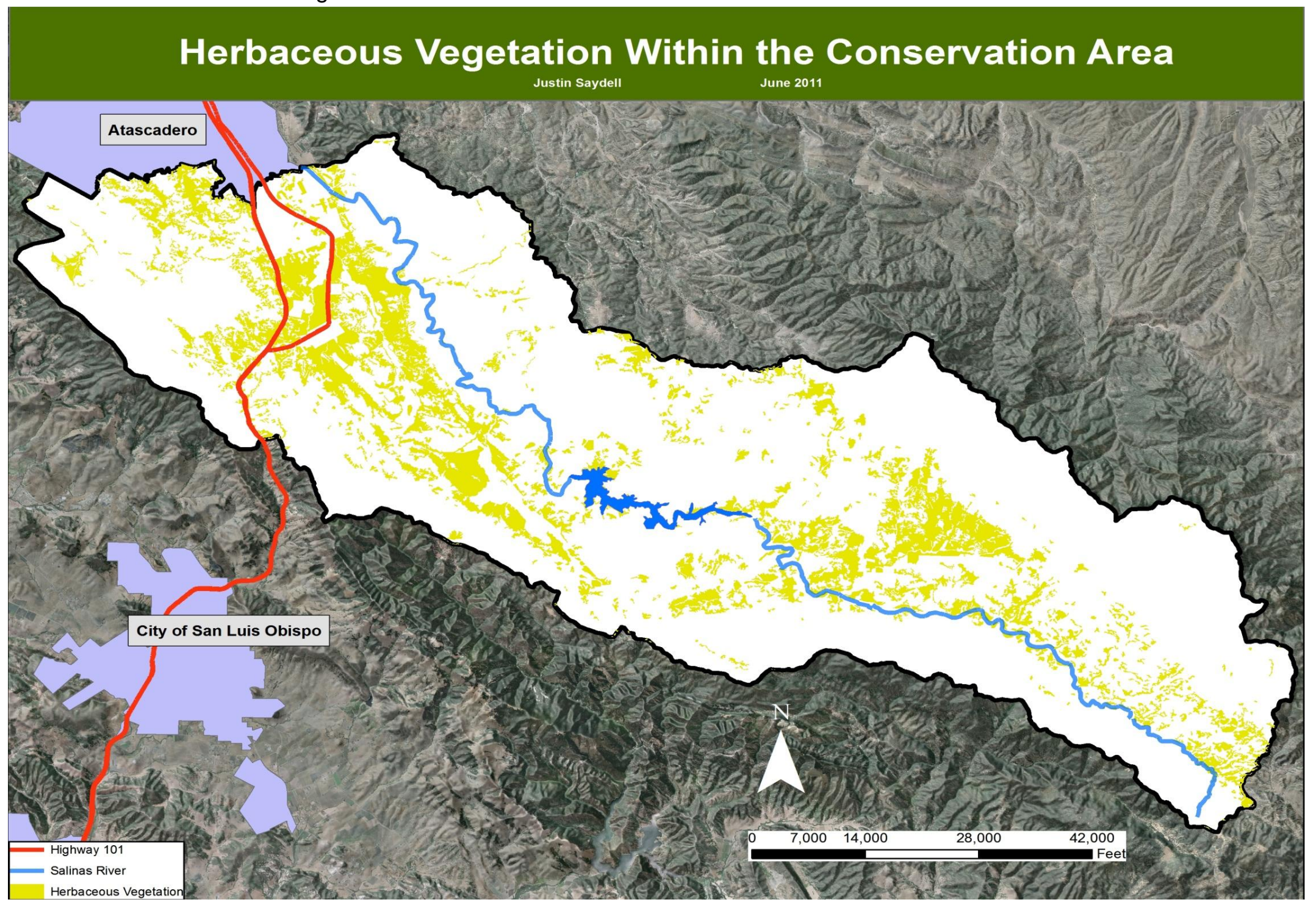


APPENDIX A Conservation Area GIS Maps

FIGURE A.15 Shrub Vegetation

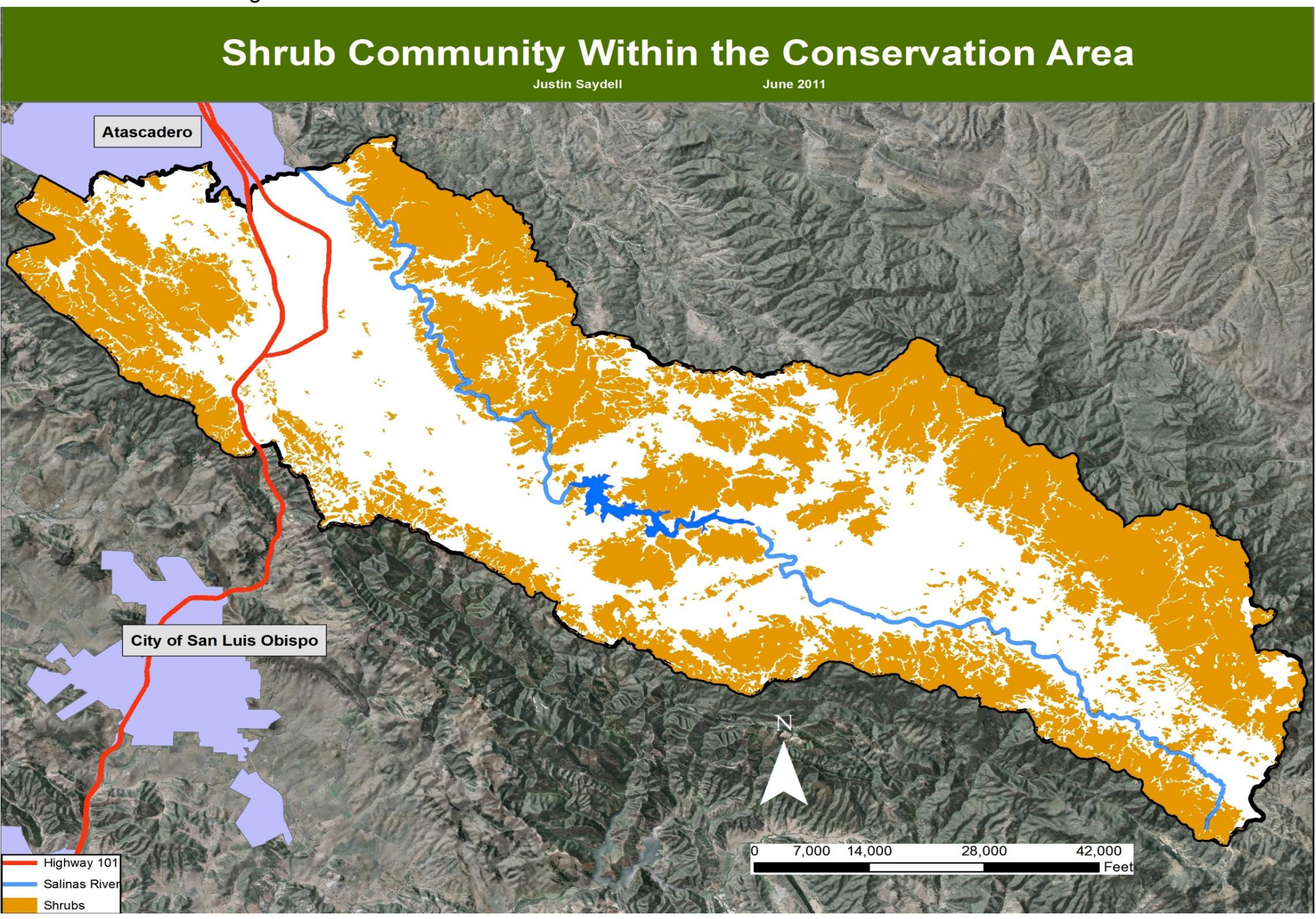


FIGURE A.17 Agricultural Soil Designations

\section{Agricultural Soil Designations Within the Conservation Area} Justin Saydell June 2011

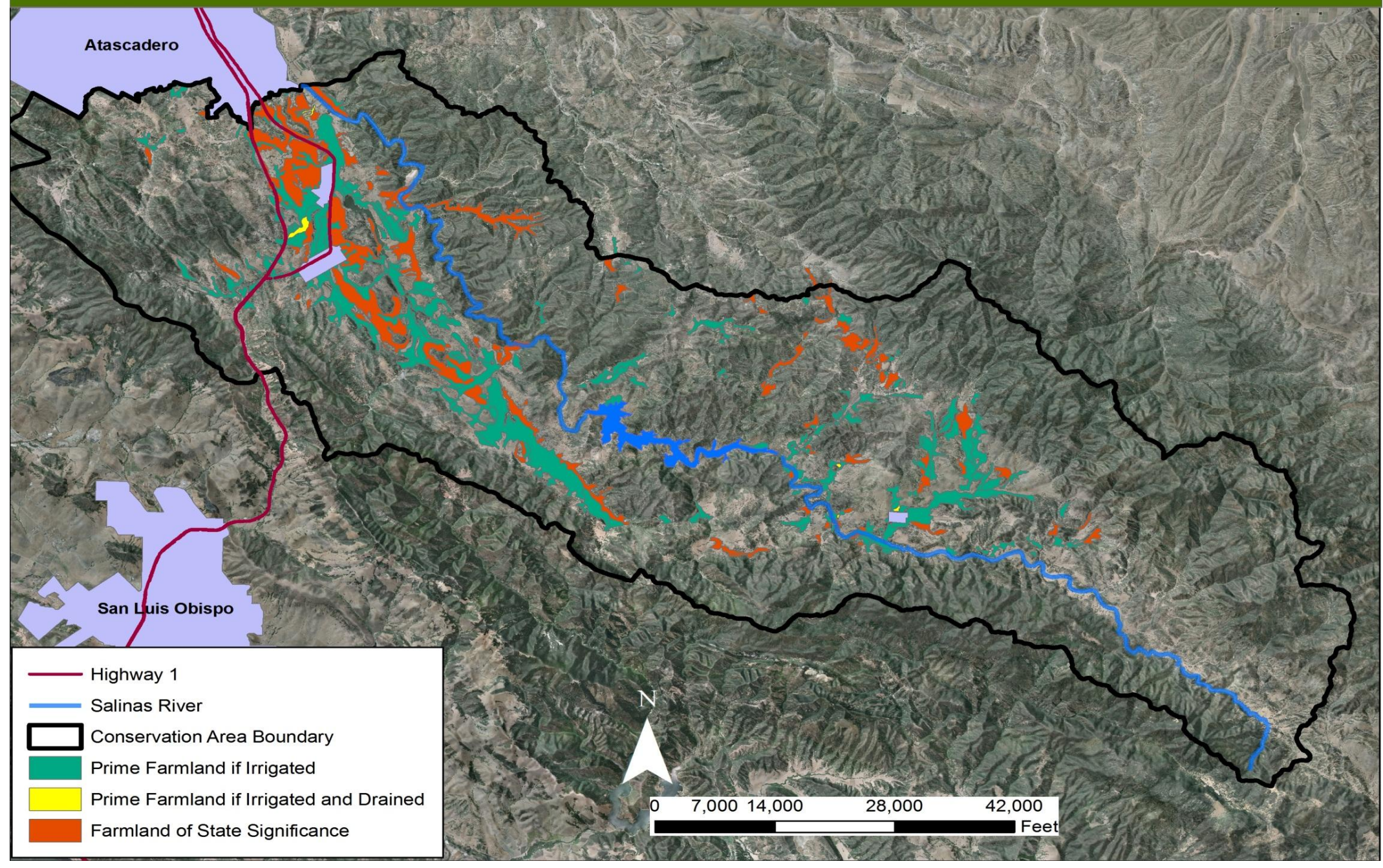




\section{APPENDIX B Plant Species in the Conservation Area}

Table B.1 Plants found within the Conservation Area according to the California Native Plant Society.

\begin{tabular}{|c|c|c|c|c|c|}
\hline Record & SCINAME & COMNAME & FEDSTATUS & CALSTATUS & CNPSLIST \\
\hline 1 & Chorizanthe breweri & $\begin{array}{l}\text { Brewer's } \\
\text { spineflower }\end{array}$ & None & None & 1B. 3 \\
\hline 2 & $\begin{array}{l}\text { Calystegia subacaulis } \\
\text { ssp. episcopalis }\end{array}$ & $\begin{array}{l}\text { Cambria morning- } \\
\text { glory }\end{array}$ & None & None & 1B.2 \\
\hline 3 & $\begin{array}{l}\text { Tropidocarpum } \\
\text { capparideum }\end{array}$ & $\begin{array}{l}\text { caper-fruited } \\
\text { tropidocarpum }\end{array}$ & None & None & 1B.1 \\
\hline 4 & $\begin{array}{l}\text { Malacothamnus } \\
\text { palmeri var. } \\
\text { involucratus }\end{array}$ & $\begin{array}{l}\text { Carmel Valley bush- } \\
\text { mallow }\end{array}$ & None & None & 1B.2 \\
\hline 5 & Senecio aphanactis & chaparral ragwort & None & None & 2.2 \\
\hline 6 & $\begin{array}{l}\text { Cirsium fontinale var. } \\
\text { obispoense }\end{array}$ & $\begin{array}{l}\text { Chorro Creek bog } \\
\text { thistle }\end{array}$ & Endangered & Endangered & 1B. 2 \\
\hline 7 & $\begin{array}{l}\text { Sidalcea hickmanii } \\
\text { ssp. anomala }\end{array}$ & $\begin{array}{l}\text { Cuesta Pass } \\
\text { checkerbloom }\end{array}$ & None & Rare & 1B.2 \\
\hline 8 & $\begin{array}{l}\text { Delphinium parryi ssp. } \\
\text { blochmaniae }\end{array}$ & dune larkspur & None & None & 1B.2 \\
\hline 9 & $\begin{array}{l}\text { Chlorogalum } \\
\text { pomeridianum var. } \\
\text { minus }\end{array}$ & dwarf soaproot & None & None & 1B. 2 \\
\hline 10 & $\begin{array}{l}\text { Camissonia } \\
\text { hardhamiae }\end{array}$ & $\begin{array}{l}\text { Hardham's evening- } \\
\text { primrose }\end{array}$ & None & None & 1B.2 \\
\hline 11 & $\begin{array}{l}\text { Plagiobothrys } \\
\text { uncinatus }\end{array}$ & $\begin{array}{l}\text { hooked popcorn- } \\
\text { flower }\end{array}$ & None & None & 1B.2 \\
\hline 12 & Agrostis hooveri & Hoover's bent grass & None & None & 1B.2 \\
\hline 13 & Layia jonesii & Jones' layia & None & None & 1B.2 \\
\hline 14 & $\begin{array}{l}\text { Calochortus } \\
\text { obispoensis }\end{array}$ & $\begin{array}{l}\text { La Panza mariposa- } \\
\text { lily }\end{array}$ & None & None & 1B.2 \\
\hline 15 & $\begin{array}{l}\text { Deinandra increscens } \\
\text { ssp. foliosa }\end{array}$ & leafy tarplant & None & None & 1B.2 \\
\hline 16 & Caulanthus lemmonii & $\begin{array}{l}\text { Lemmon's jewel- } \\
\text { flower }\end{array}$ & None & None & 1B.2 \\
\hline 17 & $\begin{array}{l}\text { Horkelia cuneata ssp. } \\
\text { puberula }\end{array}$ & mesa horkelia & None & None & 1B.1 \\
\hline 18 & $\begin{array}{l}\text { Astragalus } \\
\text { didymocarpus var. } \\
\text { milesianus }\end{array}$ & Miles' milk-vetch & None & None & 1B.2 \\
\hline 19 & $\begin{array}{l}\text { Streptanthus albidus } \\
\text { ssp. peramoenus }\end{array}$ & $\begin{array}{l}\text { most beautiful } \\
\text { jewel-flower }\end{array}$ & None & None & 1B.2 \\
\hline 20 & $\begin{array}{l}\text { Dudleya abramsii ssp. } \\
\text { murina }\end{array}$ & $\begin{array}{l}\text { mouse-gray } \\
\text { dudleya }\end{array}$ & None & None & 1B.3 \\
\hline 21 & Fritillaria ojaiensis & Ojai fritillary & None & None & 1B.2 \\
\hline 22 & Layia heterotricha & pale-yellow layia & None & None & 1B.1 \\
\hline 23 & Monardella palmeri & $\begin{array}{l}\text { Palmer's } \\
\text { monardella }\end{array}$ & None & None & 1B.2 \\
\hline 24 & $\begin{array}{l}\text { Arctostaphylos } \\
\text { pechoensis }\end{array}$ & Pecho manzanita & None & None & 1B.2 \\
\hline 25 & California macrophylla & round-leaved filaree & None & None & 1B.1 \\
\hline 26 & Lupinus ludovicianus & $\begin{array}{l}\text { San Luis Obispo } \\
\text { County lupine }\end{array}$ & None & None & 1B.2 \\
\hline 27 & Calochortus simulans & $\begin{array}{l}\text { San Luis Obispo } \\
\text { mariposa-lily }\end{array}$ & None & None & 1B.3 \\
\hline 28 & $\begin{array}{l}\text { Castilleja densiflora } \\
\text { ssp. obispoensis }\end{array}$ & $\begin{array}{l}\text { San Luis Obispo } \\
\text { owl's-clover }\end{array}$ & None & None & 1B.2 \\
\hline 29 & Carex obispoensis & $\begin{array}{l}\text { San Luis Obispo } \\
\text { sedge }\end{array}$ & None & None & 1B.2 \\
\hline 30 & $\begin{array}{l}\text { Malacothamnus } \\
\text { palmeri var. palmeri }\end{array}$ & $\begin{array}{l}\text { Santa Lucia bush- } \\
\text { mallow }\end{array}$ & None & None & 1B.2 \\
\hline
\end{tabular}




\section{APPENDIX B Plant Species in the Conservation Area}

\begin{tabular}{|r|l|l|l|l|l|} 
& & & \\
& Arctostaphylos luciana & $\begin{array}{l}\text { Santa Lucia } \\
\text { manzanita }\end{array}$ & None & None & 1 B.2 \\
\hline 32 & Arctostaphylos pilosula & $\begin{array}{l}\text { Santa Margarita } \\
\text { manzanita }\end{array}$ & None & None & 1 B.2 \\
\hline 33 & $\begin{array}{l}\text { Navarretia nigelliformis } \\
\text { ssp. radians }\end{array}$ & shining navarretia & None & None & 1 B.2 \\
\hline 34 & Chorizanthe rectispina & $\begin{array}{l}\text { straight-awned } \\
\text { spineflower }\end{array}$ & None & None & 1 B.3 \\
\hline 35 & $\begin{array}{l}\text { Delphinium } \\
\text { umbraculorum }\end{array}$ & Umbrella larkspur & None & None & 1 B.3 \\
\hline 36 & Arctostaphylos wellsii & Wells' manzanita & None & None & 1 B.1 \\
\hline 37 & Eriastrum luteum & $\begin{array}{l}\text { yellow-flowered } \\
\text { eriastrum }\end{array}$ & None & None & 1 B.2 \\
\hline
\end{tabular}

Source: California Native Plant Society 2011

Table B.2 Invasive plant species found in the Conservation Area according to the California Invasive Plant Council

\begin{tabular}{|c|c|c|c|c|c|c|c|}
\hline $\begin{array}{l}\text { Cal-IPC: The Inventory } \\
\text { Database Scientific Name }\end{array}$ & Common Name & Rating & Alert & Impacts & Invasive & Distrib & Doc. \\
\hline Alternanthera philoxeroides & alligator weed & High & Alert & $\mathrm{A}$ & $\mathrm{B}$ & $\mathrm{C}$ & 2.9 \\
\hline Eichhornia crassipes & water hyacinth & High & Alert & A & A & $\mathrm{C}$ & 3.2 \\
\hline Euphorbia esula & leafy spurge & High & Alert & $\mathrm{A}$ & A & $\mathrm{C}$ & 3.5 \\
\hline Hydrilla verticillata & hydrilla & High & Alert & A & $\mathrm{B}$ & $\mathrm{C}$ & 3.2 \\
\hline Ludwigia hexapetala & $\begin{array}{l}\text { Uruguay water- } \\
\text { primrose }\end{array}$ & High & Alert & $\mathrm{A}$ & $\mathrm{B}$ & $\mathrm{C}$ & 2.6 \\
\hline Myriophyllum aquaticum & parrotfeather & High & Alert & $\mathrm{A}$ & $\mathrm{B}$ & $\mathrm{C}$ & 2.8 \\
\hline Salvinia molesta & giant salvinia & High & Alert & A & A & $\mathrm{C}$ & 2.9 \\
\hline Sesbania punicea & $\begin{array}{l}\text { red sesbania, scarlet } \\
\text { wisteria }\end{array}$ & High & Alert & $\mathrm{A}$ & $\mathrm{B}$ & $\mathrm{C}$ & 3.2 \\
\hline $\begin{array}{l}\text { Spartina alterniflora (and S. } \\
\text { alterniflora x foliosa hybrids) }\end{array}$ & $\begin{array}{l}\text { smooth cordgrass } \\
\text { and hybrids, Atlantic } \\
\text { cordgrass }\end{array}$ & High & Alert & $\mathrm{A}$ & $A$ & $\mathrm{C}$ & 3.5 \\
\hline Spartina densiflora & $\begin{array}{l}\text { dense-flowered } \\
\text { cordgrass }\end{array}$ & High & Alert & $\mathrm{A}$ & $\mathrm{B}$ & $\mathrm{D}$ & 3.3 \\
\hline Aegilops triuncialis & barb goatgrass & High & No & $A$ & $A$ & $\mathrm{~B}$ & 3.6 \\
\hline Ammophila arenaria & $\begin{array}{l}\text { European } \\
\text { beachgrass }\end{array}$ & High & No & $\mathrm{A}$ & $\mathrm{B}$ & $\mathrm{B}$ & 3.2 \\
\hline Arundo donax & giant reed & High & No & A & B & A & 2.8 \\
\hline Brassica tournefortii & $\begin{array}{l}\text { Saharan mustard, } \\
\text { African mustard }\end{array}$ & High & No & $A$ & A & $\mathrm{B}$ & 2.3 \\
\hline $\begin{array}{l}\text { Bromus madritensis ssp. } \\
\text { rubens }\end{array}$ & red brome & High & No & $A$ & $\mathrm{~B}$ & $\mathrm{~A}$ & 3 \\
\hline Bromus tectorum & $\begin{array}{l}\text { downy brome, } \\
\text { cheatgrass }\end{array}$ & High & No & $A$ & $\mathrm{~B}$ & $A$ & 3.1 \\
\hline Carpobrotus edulis & $\begin{array}{l}\text { Hottentot-fig, } \\
\text { iceplant }\end{array}$ & High & No & $\mathrm{A}$ & $\mathrm{B}$ & $\mathrm{A}$ & 3.3 \\
\hline Centaurea maculosa & spotted knapweed & High & No & $\mathrm{A}$ & $\mathrm{B}$ & $\mathrm{B}$ & 3.4 \\
\hline Centaurea solstitialis & yellow starthistle & High & No & A & $\mathrm{B}$ & $\mathrm{A}$ & 3 \\
\hline Cortaderia jubata & jubatagrass & High & No & $\mathrm{A}$ & A & $\mathrm{A}$ & 3.1 \\
\hline Cortaderia selloana & pampasgrass & High & No & A & A & $\mathrm{B}$ & 3.2 \\
\hline Cytisus scoparius & Scotch broom & High & No & A & B & A & 3.2 \\
\hline Delairea odorata & $\begin{array}{l}\text { Cape-ivy, German- } \\
\text { ivy }\end{array}$ & High & No & $\mathrm{A}$ & $\mathrm{A}$ & $\mathrm{B}$ & 3.1 \\
\hline
\end{tabular}




\section{APPENDIX B Plant Species in the Conservation Area}

\begin{tabular}{|c|c|c|c|c|c|c|c|}
\hline Egeria densa & Brazilian egeria & High & No & A & A & $\mathrm{B}$ & 3.1 \\
\hline Ehrharta calycina & purple veldtgrass & High & No & $\mathrm{A}$ & $\mathrm{A}$ & $\mathrm{B}$ & 3.4 \\
\hline Foeniculum vulgare & fennel & High & No & A & $\mathrm{B}$ & A & 3 \\
\hline Genista monspessulana & French broom & High & No & A & A & B & 3.2 \\
\hline Hedera helix, $\mathrm{H}$. canariensis & $\begin{array}{l}\text { English ivy, Algerian } \\
\text { ivy }\end{array}$ & High & No & A & A & A & 2.7 \\
\hline Lepidium latifolium & $\begin{array}{l}\text { perennial } \\
\text { pepperweed, tall } \\
\text { whitetop }\end{array}$ & High & No & A & A & A & 3.1 \\
\hline $\begin{array}{l}\text { Ludwigia peploides ssp. } \\
\text { montevidensis }\end{array}$ & $\begin{array}{l}\text { creeping water- } \\
\text { primrose }\end{array}$ & High & No & A & B & $\mathrm{B}$ & 2.5 \\
\hline Lythrum salicaria & purple loosestrife & High & No & A & A & $\mathrm{B}$ & 3.8 \\
\hline Myriophyllum spicatum & Eurasian watermilfoil & High & No & A & $\mathrm{A}$ & $\mathrm{B}$ & 2.8 \\
\hline Onopordum acanthium & Scotch thistle & High & No & $\mathrm{B}$ & $\mathrm{B}$ & $\mathrm{B}$ & 2.9 \\
\hline Rubus armeniacus & Himalaya blackberry & High & No & $\mathrm{A}$ & $\mathrm{A}$ & $\mathrm{A}$ & 3 \\
\hline Spartium junceum & Spanish broom & High & No & A & B & $\mathrm{B}$ & 3.2 \\
\hline $\begin{array}{l}\text { Taeniatherum caput- } \\
\text { medusae }\end{array}$ & medusahead & High & No & A & A & A & 3.4 \\
\hline Tamarix parviflora & smallflower tamarisk & High & No & A & A & $\mathrm{B}$ & 3.1 \\
\hline Tamarix ramosissima & saltcedar, tamarisk & High & No & A & A & $\mathrm{A}$ & 3.3 \\
\hline Ulex europaeus & gorse & High & No & A & B & B & 2.9 \\
\hline Acacia melanoxylon & $\begin{array}{l}\text { black acacia, } \\
\text { blackwood acacia }\end{array}$ & Limited & No & $\mathrm{C}$ & $\mathrm{C}$ & $\mathrm{B}$ & 2.7 \\
\hline Agrostis avenacea & Pacific bentgrass & Limited & No & $\mathrm{C}$ & $\mathrm{C}$ & $\mathrm{C}$ & 2.4 \\
\hline Agrostis stolonifera & creeping bentgrass & Limited & No & C & $\mathrm{B}$ & C & 1.9 \\
\hline Bassia hyssopifolia & fivehook bassia & Limited & No & $\mathrm{C}$ & $\mathrm{C}$ & $\mathrm{B}$ & 2.7 \\
\hline Bellardia trixago & bellardia & Limited & No & $\mathrm{C}$ & $\mathrm{C}$ & C & 1.9 \\
\hline Brassica rapa & $\begin{array}{l}\text { birdsrape mustard, } \\
\text { field mustard }\end{array}$ & Limited & No & C & B & $\mathrm{B}$ & 1.8 \\
\hline Briza maxima & $\begin{array}{l}\text { big quackingrass, } \\
\text { rattlesnakegrass }\end{array}$ & Limited & No & $\mathrm{B}$ & $\mathrm{C}$ & $\mathrm{B}$ & 2.3 \\
\hline Bromus hordeaceus & soft brome & Limited & No & $\mathrm{B}$ & $\mathrm{C}$ & $\mathrm{A}$ & 2.8 \\
\hline Bromus japonicus & $\begin{array}{l}\text { Japanese brome, } \\
\text { Japanese chess }\end{array}$ & Limited & No & $\mathrm{B}$ & C & $\mathrm{B}$ & 2.6 \\
\hline Cakile maritima & European sea-rocket & Limited & No & $\mathrm{C}$ & $\mathrm{B}$ & $\mathrm{B}$ & 3.6 \\
\hline Cardaria pubescens & hairy whitetop & Limited & No & $\mathrm{C}$ & $\mathrm{B}$ & $\mathrm{C}$ & 2.5 \\
\hline Carduus acanthoides & plumeless thistle & Limited & No & $\mathrm{B}$ & $\mathrm{C}$ & $\mathrm{C}$ & 3 \\
\hline Carduus tenuiflorus & slenderflower thistle & Limited & No & C & $\mathrm{C}$ & B & 2.8 \\
\hline Conicosia pugioniformis & narrowleaf iceplant & Limited & No & $\mathrm{C}$ & B & $\mathrm{C}$ & 2.1 \\
\hline Cordyline australis & $\begin{array}{l}\text { giant dracaena, New } \\
\text { Zealand cabbage } \\
\text { tree }\end{array}$ & Limited & No & $\mathrm{C}$ & $\mathrm{C}$ & $\mathrm{C}$ & 2 \\
\hline Cotula coronopifolia & brassbuttons & Limited & No & $\mathrm{C}$ & $\mathrm{C}$ & $\mathrm{B}$ & 2.2 \\
\hline Crataegus monogyna & hawthorn & Limited & No & C & $\mathrm{B}$ & $\mathrm{C}$ & 3.4 \\
\hline Crocosmia $\mathrm{x}$ crocosmiiflora & montbretia & Limited & No & C & B & $\mathrm{B}$ & 2.6 \\
\hline Crupina vulgaris & $\begin{array}{l}\text { common crupina, } \\
\text { bearded creeper }\end{array}$ & Limited & No & $\mathrm{B}$ & $\mathrm{C}$ & $\mathrm{B}$ & 3.2 \\
\hline Dactylis glomerata & orchardgrass & Limited & No & $\mathrm{C}$ & B & $\mathrm{B}$ & 2.9 \\
\hline Descurainia sophia & $\begin{array}{l}\text { flixweed, tansy } \\
\text { mustard }\end{array}$ & Limited & No & C & B & B & 1.9 \\
\hline
\end{tabular}




\section{APPENDIX B Plant Species in the Conservation Area}

\begin{tabular}{|c|c|c|c|c|c|c|c|}
\hline Digitalis purpurea & foxglove & Limited & No & C & $\mathrm{B}$ & $\mathrm{B}$ & 2.4 \\
\hline Echium candicans & pride-of-Madeira & Limited & No & C & B & B & 1.5 \\
\hline Erodium cicutarium & redstem filaree & Limited & No & $\mathrm{C}$ & $\mathrm{C}$ & A & 3.1 \\
\hline Eucalyptus camaldulensis & red gum & Limited & No & C & C & C & 2.2 \\
\hline Euphorbia oblongata & oblong spurge & Limited & No & C & C & B & 2 \\
\hline Helichrysum petiolare & licoriceplant & Limited & No & $\mathrm{C}$ & B & $\mathrm{C}$ & 2 \\
\hline Hypochaeris glabra & smooth catsear & Limited & No & $\mathrm{C}$ & B & $\mathrm{B}$ & 3.1 \\
\hline Iris pseudacorus & yellowflag iris & Limited & No & $\mathrm{C}$ & B & $\mathrm{C}$ & 2.3 \\
\hline Lobularia maritima & sweet alyssum & Limited & No & $\mathrm{C}$ & B & B & 2.4 \\
\hline Lythrum hyssopifolium & hyssop loosestrife & Limited & No & C & B & $\mathrm{B}$ & 3 \\
\hline Marrubium vulgare & white horehound & Limited & No & C & C & $\mathrm{B}$ & 2.8 \\
\hline Medicago polymorpha & California burclover & Limited & No & C & c & A & 2.8 \\
\hline Myosotis latifolia & $\begin{array}{l}\text { common forget-me- } \\
\text { not }\end{array}$ & Limited & No & C & B & $\mathrm{B}$ & 2.2 \\
\hline Olea europaea & olive & Limited & No & C & B & $\mathrm{B}$ & 2.5 \\
\hline Ononis alopecuroides & foxtail restharrow & Limited & No & C & B & C & 2.2 \\
\hline Parentucellia viscosa & $\begin{array}{l}\text { yellow glandweed, } \\
\text { sticky parentucellia }\end{array}$ & Limited & No & $\mathrm{C}$ & $\mathrm{B}$ & $\mathrm{B}$ & 2.5 \\
\hline Pennisetum clandestinum & kikuyugrass & Limited & No & C & C & B & 2.3 \\
\hline Phoenix canariensis & $\begin{array}{l}\text { Canary Island date } \\
\text { palm }\end{array}$ & Limited & No & C & B & $\mathrm{D}$ & 2.3 \\
\hline Phytolacca americana & common pokeweed & Limited & No & $\mathrm{C}$ & B & $\mathrm{C}$ & 2.8 \\
\hline Picris echioides & bristly oxtongue & Limited & No & $\mathrm{C}$ & $\mathrm{B}$ & $\mathrm{B}$ & 2.4 \\
\hline Piptatherum miliaceum & smilograss & Limited & No & C & B & B & 2.4 \\
\hline Plantago lanceolata & $\begin{array}{l}\text { buckhorn plantain, } \\
\text { English plantain }\end{array}$ & Limited & No & $\mathrm{C}$ & $\mathrm{C}$ & $\mathrm{B}$ & 2.1 \\
\hline Poa pratensis & Kentucky bluegrass & Limited & No & C & B & B & 2.7 \\
\hline $\begin{array}{l}\text { Polypogon monspeliensis } \\
\text { and subspp. }\end{array}$ & $\begin{array}{l}\text { rabbitfoot } \\
\text { polypogon, annual } \\
\text { beardgrass }\end{array}$ & Limited & No & C & C & B & 2.3 \\
\hline Prunus cerasifera & cherry plum & Limited & No & $\mathrm{C}$ & B & $\mathrm{B}$ & 1.8 \\
\hline $\begin{array}{l}\text { Pyracantha angustifolia, P. } \\
\text { crenulata, P. coccinea }\end{array}$ & pyracantha, firethorn & Limited & No & C & B & $\mathrm{B}$ & 2.8 \\
\hline Ranunculus repens & creeping buttercup & Limited & No & C & C & B & 2.9 \\
\hline Raphanus sativus & radish & Limited & No & $\mathrm{C}$ & $\mathrm{C}$ & $\mathrm{B}$ & 2.5 \\
\hline Ricinus communis & castorbean & Limited & No & $\mathrm{C}$ & B & $\mathrm{B}$ & 2.5 \\
\hline Robinia pseudoacacia & black locust & Limited & No & $\mathrm{C}$ & $\mathrm{B}$ & $\mathrm{B}$ & 2.8 \\
\hline Rumex crispus & curly dock & Limited & No & C & C & A & 2.7 \\
\hline Salsola paulsenii & $\begin{array}{l}\text { barbwire Russian- } \\
\text { thistle }\end{array}$ & Limited & No & C & $\mathrm{C}$ & $\mathrm{C}$ & 2.9 \\
\hline Salsola tragus & Russian-thistle & Limited & No & $\mathrm{C}$ & B & $\mathrm{B}$ & 2.8 \\
\hline Salvia aethiopis & Mediterranean sage & Limited & No & $\mathrm{C}$ & B & $\mathrm{B}$ & 2.5 \\
\hline Saponaria officinalis & bouncingbet & Limited & No & C & B & C & 2.5 \\
\hline Schinus molle & Peruvian peppertree & Limited & No & C & B & B & 2.5 \\
\hline Schinus terebinthifolius & Brazilian peppertree & Limited & No & C & B & C & 2.6 \\
\hline $\begin{array}{l}\text { Schismus arabicus, } \\
\text { Schismus barbatus }\end{array}$ & mediterraneangrass & Limited & No & B & C & A & 2.3 \\
\hline
\end{tabular}




\section{APPENDIX B Plant Species in the Conservation Area}

\begin{tabular}{|c|c|c|c|c|c|c|c|}
\hline Senecio jacobaea & tansy ragwort & Limited & No & $\mathrm{C}$ & B & B & 2.8 \\
\hline Silybum marianum & blessed milkthistle & Limited & No & c & C & A & 3.5 \\
\hline Sinapis arvensis & $\begin{array}{l}\text { wild mustard, } \\
\text { charlock }\end{array}$ & Limited & No & C & C & C & 2.9 \\
\hline Spartina patens & $\begin{array}{l}\text { saltmeadow cord } \\
\text { grass }\end{array}$ & Limited & No & C & $\mathrm{C}$ & $\mathrm{D}$ & 2.9 \\
\hline Tamarix aphylla & athel tamarisk & Limited & No & C & $\mathrm{B}$ & B & 3.5 \\
\hline Undaria pinnatifida & wakame & Limited & No & c & B & C & 3.3 \\
\hline Verbascum thapsus & $\begin{array}{l}\text { common } \\
\text { mullein,woolly } \\
\text { mullein } \\
\end{array}$ & Limited & No & C & $\mathrm{B}$ & B & 3.8 \\
\hline Watsonia meriana & bulbil watsonia & Limited & No & C & $\mathrm{B}$ & C & 2.3 \\
\hline Zantedeschia aethiopica & calla lily & Limited & No & $\mathrm{C}$ & $\mathrm{B}$ & $\mathrm{C}$ & 2.1 \\
\hline Arctotheca calendula (fertile) & fertile capeweed & Moderate & Alert & B & $\mathrm{B}$ & $\mathrm{C}$ & 3.6 \\
\hline Asparagus asparagoides & bridal creeper & Moderate & Alert & $\mathrm{B}$ & $\mathrm{B}$ & $\mathrm{D}$ & 2.6 \\
\hline Asphodelus fistulosus & onionweed & Moderate & Alert & B & A & c & 2.9 \\
\hline Brachypodium sylvaticum & $\begin{array}{l}\begin{array}{l}\text { perennial false- } \\
\text { brome }\end{array} \\
\end{array}$ & Moderate & Alert & B & A & $\mathrm{D}$ & 2.5 \\
\hline Cardaria chalepensis & $\begin{array}{l}\text { lens-podded white- } \\
\text { top }\end{array}$ & Moderate & Alert & $\mathrm{B}$ & $\mathrm{B}$ & $\mathrm{C}$ & 3.2 \\
\hline Carthamus lanatus & woolly distaff thistle & Moderate & Alert & A & $\mathrm{B}$ & C & 2.8 \\
\hline Centaurea debeauxii & meadow knapweed & Moderate & Alert & B & B & c & 2.7 \\
\hline Dittrichia graveolens & stinkwort & Moderate & Alert & B & A & C & 3 \\
\hline Ehrharta longiflora & $\begin{array}{l}\text { long-flowered } \\
\text { veldtgrass }\end{array}$ & Moderate & Alert & B & B & C & 2.8 \\
\hline Emex spinosa & $\begin{array}{l}\text { spiny emex, devil's- } \\
\text { thorn }\end{array}$ & Moderate & Alert & B & $\mathrm{B}$ & $\mathrm{D}$ & 1.6 \\
\hline Euphorbia terracina & carnation spurge & Moderate & Alert & B & $B$ & C & 1.7 \\
\hline Hypericum canariense & $\begin{array}{l}\text { Canary Island } \\
\text { hypericum }\end{array}$ & Moderate & Alert & B & $\mathrm{B}$ & $\mathrm{C}$ & 1.2 \\
\hline Ilex aquifolium & English holly & Moderate & Alert & B & B & C & 2.7 \\
\hline $\begin{array}{l}\text { Mesembryanthemum } \\
\text { crystallinum }\end{array}$ & crystalline iceplant & Moderate & Alert & B & $\mathrm{B}$ & C & 3.7 \\
\hline Polygonum cuspidatum & Japanese knotweed & Moderate & Alert & $\mathrm{B}$ & $\mathrm{B}$ & $\mathrm{D}$ & 2.7 \\
\hline Polygonum sachalinense & Sakhalin knotweed & Moderate & Alert & $\mathrm{B}$ & $\mathrm{B}$ & $\mathrm{D}$ & 2.5 \\
\hline Retama monosperma & bridal broom & Moderate & Alert & $\mathrm{B}$ & $\mathrm{B}$ & $\mathrm{C}$ & 1.8 \\
\hline Saccharum ravennae & ravennagrass & Moderate & Alert & $\mathrm{B}$ & $\mathrm{A}$ & $\mathrm{C}$ & \\
\hline Sapium sebiferum & Chinese tallowtree & Moderate & Alert & $\mathrm{B}$ & $\mathrm{B}$ & C & 3.2 \\
\hline Spartina anglica & common cordgrass & Moderate & Alert & B & B & $\mathrm{D}$ & 3.4 \\
\hline Stipa capensis & $\begin{array}{l}\text { Mediterranean } \\
\text { steppegrass,twisted- } \\
\text { awned speargrass }\end{array}$ & Moderate & Alert & B & $\mathrm{B}$ & D & 1.9 \\
\hline Washingtonia robusta & Mexican fan palm & Moderate & Alert & $\mathrm{B}$ & $\mathrm{B}$ & C & 2.7 \\
\hline Acacia dealbata & silver wattle & Moderate & No & B & $\mathrm{B}$ & B & 2.5 \\
\hline Acroptilon repens & Russian knapweed & Moderate & No & B & B & B & 3.2 \\
\hline Ageratina adenophora & $\begin{array}{l}\text { croftonweed, } \\
\text { eupatorium }\end{array}$ & Moderate & No & B & $\mathrm{B}$ & B & 2.8 \\
\hline Ailanthus altissima & tree-of-heaven & Moderate & No & B & $\mathrm{B}$ & B & 3 \\
\hline Alhagi maurorum & camelthorn & Moderate & No & $\mathrm{B}$ & $\mathrm{B}$ & $\mathrm{B}$ & 3.2 \\
\hline Anthoxanthum odoratum & sweet vernalgrass & Moderate & No & B & $\mathrm{B}$ & B & 2.7 \\
\hline
\end{tabular}




\section{APPENDIX B Plant Species in the Conservation Area}

\begin{tabular}{|c|c|c|c|c|c|c|c|}
\hline $\begin{array}{l}\text { Arctotheca calendula } \\
\text { (sterile) }\end{array}$ & sterile capeweed & Moderate & No & B & $\mathrm{B}$ & $\mathrm{B}$ & 2.8 \\
\hline Atriplex semibaccata & Australian saltbush & Moderate & No & $\mathrm{B}$ & $\mathrm{B}$ & $\mathrm{B}$ & 2.9 \\
\hline Avena barbata & slender wild oat & Moderate & No & B & B & A & 3.5 \\
\hline Avena fatua & wild oat & Moderate & No & B & B & A & 3.2 \\
\hline Brachypodium distachyon & $\begin{array}{l}\text { annual false-brome, } \\
\text { false brome, purple } \\
\text { false broom, stiff } \\
\text { brome }\end{array}$ & Moderate & No & B & $\mathrm{B}$ & $\mathrm{B}$ & 2.6 \\
\hline Brassica nigra & black mustard & Moderate & No & B & B & A & 2 \\
\hline Bromus diandrus & ripgut brome & Moderate & No & B & B & A & 3.3 \\
\hline Cardaria draba & hoary cress & Moderate & No & B & B & B & 2.6 \\
\hline Carduus nutans & musk thistle & Moderate & No & B & $\mathrm{B}$ & $\mathrm{B}$ & 3.1 \\
\hline Carduus pycnocephalus & Italian thistle & Moderate & No & B & B & $\mathrm{A}$ & 2.9 \\
\hline Carpobrotus chilensis & sea-fig, iceplant & Moderate & No & B & B & A & 1.8 \\
\hline Centaurea calcitrapa & purple starthistle & Moderate & No & B & B & B & 2.7 \\
\hline Centaurea diffusa & diffuse knapweed & Moderate & No & B & B & B & 3.3 \\
\hline Centaurea melitensis & $\begin{array}{l}\text { Malta starthistle, } \\
\text { tocalote }\end{array}$ & Moderate & No & B & B & B & 2.6 \\
\hline $\begin{array}{l}\text { Centaurea virgata ssp. } \\
\text { squarrosa }\end{array}$ & squarrose knapweed & Moderate & No & B & B & $\mathrm{B}$ & 2.8 \\
\hline Chondrilla juncea & rush skeletonweed & Moderate & No & B & B & $\mathrm{B}$ & 3.1 \\
\hline Chrysanthemum coronarium & crown daisy & Moderate & No & B & B & B & 2 \\
\hline Cirsium arvense & Canada thistle & Moderate & No & B & $\mathrm{B}$ & $\mathrm{B}$ & 2.8 \\
\hline Cirsium vulgare & bull thistle & Moderate & No & B & B & $\mathrm{B}$ & 3.3 \\
\hline Conium maculatum & poison-hemlock & Moderate & No & B & B & B & 2.8 \\
\hline Cotoneaster franchetii & orange cotoneaster & Moderate & No & $\mathrm{B}$ & A & $\mathrm{B}$ & 2.6 \\
\hline Cotoneaster lacteus & $\begin{array}{l}\text { Parney's } \\
\text { cotoneaster }\end{array}$ & Moderate & No & B & B & B & 2.1 \\
\hline Cotoneaster pannosus & $\begin{array}{l}\begin{array}{l}\text { silverleaf } \\
\text { cotoneaster }\end{array} \\
\end{array}$ & Moderate & No & B & A & B & 2.5 \\
\hline Cynara cardunculus & artichoke thistle & Moderate & No & B & B & B & 4 \\
\hline Cynodon dactylon & bermudagrass & Moderate & No & B & $\mathrm{B}$ & $\mathrm{B}$ & 3.3 \\
\hline Cynoglossum officinale & houndstongue & Moderate & No & B & B & B & 2.5 \\
\hline Cynosurus echinatus & $\begin{array}{l}\text { hedgehog } \\
\text { dogtailgrass }\end{array}$ & Moderate & No & B & B & A & 2.5 \\
\hline Cytisus striatus & Portuguese broom & Moderate & No & B & $\mathrm{B}$ & $\mathrm{B}$ & 2.7 \\
\hline Dipsacus fullonum & common teasel & Moderate & No & B & $\mathrm{B}$ & B & 3.8 \\
\hline Dipsacus sativus & fuller's teasel & Moderate & No & B & B & B & 3.8 \\
\hline Ehrharta erecta & erect veldtgrass & Moderate & No & $\mathrm{B}$ & $\mathrm{B}$ & $\mathrm{B}$ & 2.2 \\
\hline Elaeagnus angustifolia & Russian-olive & Moderate & No & B & A & B & 3.3 \\
\hline $\begin{array}{l}\text { Erechtites glomerata, E. } \\
\text { minima }\end{array}$ & $\begin{array}{l}\text { Australian fireweed, } \\
\text { Australian burnweed }\end{array}$ & Moderate & No & $\mathrm{C}$ & B & A & 3.2 \\
\hline Eucalyptus globulus & $\begin{array}{l}\text { Tasmanian blue } \\
\text { gum }\end{array}$ & Moderate & No & B & B & B & 2.8 \\
\hline Festuca arundinacea & tall fescue & Moderate & No & B & B & A & 2.9 \\
\hline Ficus carica & edible fig & Moderate & No & B & A & B & 2.6 \\
\hline Geranium dissectum & cutleaf geranium & Moderate & No & C & B & A & 1.7 \\
\hline
\end{tabular}




\section{APPENDIX B Plant Species in the Conservation Area}

\begin{tabular}{|c|c|c|c|c|c|c|c|}
\hline Glyceria declinata & waxy mannagrass & Moderate & No & $\mathrm{B}$ & $\mathrm{B}$ & $\mathrm{B}$ & 1.9 \\
\hline Halogeton glomeratus & halogeton & Moderate & No & $\mathrm{B}$ & A & $\mathrm{B}$ & 3 \\
\hline Hirschfeldia incana & $\begin{array}{l}\text { shortpod mustard, } \\
\text { summer mustard }\end{array}$ & Moderate & No & $\mathrm{B}$ & $\mathrm{B}$ & A & 1.9 \\
\hline Holcus lanatus & $\begin{array}{l}\text { common velvet } \\
\text { grass }\end{array}$ & Moderate & No & B & B & A & 2.9 \\
\hline $\begin{array}{l}\text { Hordeum marinum, } \mathrm{H} \text {. } \\
\text { murinum }\end{array}$ & $\begin{array}{l}\text { Mediterranean } \\
\text { barley, hare barley, } \\
\text { wall barley }\end{array}$ & Moderate & No & B & B & A & 2.8 \\
\hline Hypericum perforatum & $\begin{array}{l}\text { common St. John's } \\
\text { wort, klamathweed }\end{array}$ & Moderate & No & $\mathrm{B}$ & $\mathrm{B}$ & $\mathrm{B}$ & 3.7 \\
\hline Hypochaeris radicata & $\begin{array}{l}\text { rough catsear, hairy } \\
\text { dandelion }\end{array}$ & Moderate & No & $\mathrm{C}$ & $\mathrm{B}$ & A & 2.2 \\
\hline Isatis tinctoria & dyer's woad & Moderate & No & $\mathrm{B}$ & $\mathrm{B}$ & A & 3 \\
\hline Kochia scoparia & kochia & Moderate & No & $\mathrm{B}$ & $\mathrm{C}$ & $\mathrm{B}$ & 3.2 \\
\hline Leucanthemum vulgare & ox-eye daisy & Moderate & No & B & B & B & 2.5 \\
\hline $\begin{array}{l}\text { Linaria genistifolia ssp. } \\
\text { dalmatica }\end{array}$ & Dalmation toadflax & Moderate & No & $\mathrm{B}$ & $\mathrm{B}$ & $\mathrm{B}$ & 2.8 \\
\hline Linaria vulgaris & $\begin{array}{l}\text { yellow toadflax, } \\
\text { butter and eggs }\end{array}$ & Moderate & No & $\mathrm{B}$ & $\mathrm{B}$ & $\mathrm{B}$ & 2.3 \\
\hline Lolium multiflorum & Italian ryegrass & Moderate & No & A & $\mathrm{B}$ & A & 2.6 \\
\hline Mentha pulegium & pennyroyal & Moderate & No & $\mathrm{C}$ & $\mathrm{A}$ & A & 2.7 \\
\hline Myoporum laetum & myoporum & Moderate & No & $\mathrm{B}$ & $\mathrm{B}$ & $\mathrm{B}$ & 2.6 \\
\hline Nicotiana glauca & tree tobacco & Moderate & No & $\mathrm{B}$ & $\mathrm{B}$ & $\mathrm{B}$ & 2.5 \\
\hline Oxalis pes-caprae & $\begin{array}{l}\text { Bermuda buttercup, } \\
\text { buttercup oxalis, } \\
\text { yellow oxalis }\end{array}$ & Moderate & No & B & $\mathrm{B}$ & $\mathrm{B}$ & 2.9 \\
\hline Pennisetum setaceum & $\begin{array}{l}\text { crimson } \\
\text { fountaingrass }\end{array}$ & Moderate & No & $\mathrm{B}$ & $\mathrm{B}$ & $\mathrm{B}$ & 2.9 \\
\hline Phalaris aquatica & hardinggrass & Moderate & No & $\mathrm{B}$ & $\mathrm{B}$ & $\mathrm{B}$ & 2.6 \\
\hline Potamogeton crispus & curlyleaf pondweed & Moderate & No & $\mathrm{B}$ & $\mathrm{B}$ & $\mathrm{B}$ & 3.2 \\
\hline Rumex acetosella & $\begin{array}{l}\text { red sorrel, sheep } \\
\text { sorrel }\end{array}$ & Moderate & No & $\mathrm{B}$ & $\mathrm{B}$ & A & 2.3 \\
\hline Salsola soda & $\begin{array}{l}\text { oppositeleaf Russian } \\
\text { thistle }\end{array}$ & Moderate & No & $\mathrm{B}$ & $\mathrm{B}$ & $\mathrm{B}$ & 2.8 \\
\hline Sisymbrium irio & London rocket & Moderate & No & $\mathrm{B}$ & $\mathrm{B}$ & A & 1.9 \\
\hline Tanacetum vulgare & common tansy & Moderate & No & $\mathrm{B}$ & $\mathrm{B}$ & $\mathrm{B}$ & 2.3 \\
\hline Torilis arvensis & hedgeparsley & Moderate & No & C & $\mathrm{B}$ & $\mathrm{B}$ & 2.3 \\
\hline Trifolium hirtum & rose clover & Moderate & No & C & $\mathrm{B}$ & $\mathrm{B}$ & 2.8 \\
\hline Vinca major & big periwinkle & Moderate & No & $\mathrm{B}$ & $\mathrm{B}$ & $\mathrm{B}$ & 2.8 \\
\hline Vulpia myuros & rattail fescue & Moderate & No & $\mathrm{B}$ & $\mathrm{B}$ & $\mathrm{A}$ & 3 \\
\hline Cupressus macrocarpa & Monterey cypress & Native & No & $\mathrm{B}$ & $\mathrm{B}$ & $\mathrm{B}$ & 2.3 \\
\hline Lupinus arboreus & yellow bush lupine & Native & No & $\mathrm{B}$ & $\mathrm{B}$ & $\mathrm{B}$ & 3.5 \\
\hline Phragmites australis & common reed & Native & No & $\mathrm{B}$ & $\mathrm{B}$ & $\mathrm{B}$ & 2.5 \\
\hline Pinus radiata cultivars & Monterey pine & Native & No & B & $\mathrm{B}$ & $\mathrm{B}$ & 2.6 \\
\hline
\end{tabular}

Source: California Invasive Plant Council 2011 


\section{APPENDIX B Plant Species in the Conservation Area}

Table B.3 Special Status Plant Species occurring within the Conservation Area

\begin{tabular}{|c|c|c|}
\hline Species & $\begin{array}{c}\text { Status }^{1} \\
\text { Fed/CDFG/CNPS }\end{array}$ & $\begin{array}{l}\text { Habitat Requirements and } \\
\text { Blooming Period }{ }^{2}\end{array}$ \\
\hline $\begin{array}{l}\text { Santa Lucia manzanita } \\
\text { Arctostaphylos luciana }\end{array}$ & $--/--/$ List 1B & $\begin{array}{l}\text { Chaparral; cismontane } \\
\text { woodland; on shale outcrops, on } \\
\text { slopes: } 1,150 \text { to } 2,750 \text { blooms } \\
\text { February to March. }\end{array}$ \\
\hline $\begin{array}{l}\text { Catalina mariposa lily } \\
\text { Calochortus catalinae }\end{array}$ & $--/$-/List 4 & $\begin{array}{l}\text { Valley and foothill grasslands; } \\
\text { cismontane woodland; chaparral; } \\
\text { sandy soils, often granite, } \\
\text { sometime serpentine; } 1,300 \text { to } \\
3,600 \text { feet; blooms April to May. }\end{array}$ \\
\hline $\begin{array}{l}\text { San Luis Obispo mariposa } \\
\quad \text { lily } \\
\text { Calochortus simulans }\end{array}$ & $--/--/$ List 1B & $\begin{array}{l}\text { Valley and foothill grasslands; } \\
\text { cismontane woodland; chaparral; } \\
\text { sandy soils, often granite, } \\
\text { sometime serpentine; } 1,300 \text { to } \\
3,600 \text { feet; blooms April to May. }\end{array}$ \\
\hline $\begin{array}{l}\text { San Luis Obispo County } \\
\text { morning glory } \\
\text { Calystegia subacaulis ssp } \\
\text { episcopalis }\end{array}$ & $--/--/$ List 1B & $\begin{array}{l}\text { Chaparral, cismontane } \\
\text { woodland, grasslands; } 200 \text { to } \\
1640 \text { feet; blooms April to May. }\end{array}$ \\
\hline $\begin{array}{l}\text { Obispo owl's clover } \\
\text { Castilleja densiffora ssp. } \\
\text { obispoensis }\end{array}$ & $--/--/$ List 1B & $\begin{array}{l}\text { Valley and foothill grasslands; } 30 \\
\text { to } 700 \text { feet; blooms in April. }\end{array}$ \\
\hline $\begin{array}{l}\text { Straight-awned spineflower } \\
\text { Chorizanthe rectispina }\end{array}$ & $--/--/$ List 1B & $\begin{array}{l}\text { Chaparral, cismontane } \\
\text { woodland, coastal scrub. Often } \\
\text { on granite in chaparral or on } \\
\text { shale in coastal scrub; blooms } \\
\text { from May to June. }\end{array}$ \\
\hline $\begin{array}{l}\text { San Luis Obispo County } \\
\text { lupine } \\
\text { Lupinus ludovicianus }\end{array}$ & $--/--/$ List 1B & $\begin{array}{l}\text { Chaparral, cismontane } \\
\text { woodland; open areas in sandy } \\
\text { soil; Santa Margarita Formation; } \\
165 \text { to } 1,725 \text { feet; blooms April to } \\
\text { June. }\end{array}$ \\
\hline $\begin{array}{l}\text { Caper-fruited } \\
\text { tropidocarpum } \\
\text { Tropidocarpum } \\
\text { capparideum }\end{array}$ & $--/-/$ List 1B & $\begin{array}{l}\text { Chaparral, cismontane } \\
\text { woodland, coastal scrub. Often } \\
\text { on granite in chaparral or on } \\
\text { shale in coastal scrub; blooms } \\
\text { from May to June. }\end{array}$ \\
\hline
\end{tabular}

Source: Santa Margarita Ranch Agricultural Residential Cluster Subdivision Environmental Impact Statement (2008) 


\section{APPENDIX C Wildlife Species in the Conservation Area}

Table C.1 A list of species gathered from a search of the California Natural Diversity Database

\begin{tabular}{|c|c|c|c|c|c|}
\hline Record & Scientific Name & Common Name & $\begin{array}{l}\text { Federal } \\
\text { Status }\end{array}$ & $\begin{array}{l}\text { California } \\
\text { Status }\end{array}$ & $\begin{array}{l}\text { Dept of Fish } \\
\text { and Game } \\
\text { Status }\end{array}$ \\
\hline 1 & Taxidea taxus & American badger & None & None & SSC \\
\hline 2 & Polyphylla nubila & Atascadero June beetle & None & None & \\
\hline 3 & $\begin{array}{l}\text { Gymnogyps } \\
\text { californianus }\end{array}$ & California condor & Endangered & Endangered & \\
\hline 4 & $\begin{array}{l}\text { Linderiella } \\
\text { occidentalis }\end{array}$ & California linderiella & None & None & \\
\hline 5 & Rana draytonii & $\begin{array}{l}\text { California red-legged } \\
\text { frog }\end{array}$ & Threatened & None & SSC \\
\hline 6 & Taricha torosa & Coast Range newt & None & None & SSC \\
\hline 7 & Buteo regalis & ferruginous hawk & None & None & WL \\
\hline 8 & Rana boylii & $\begin{array}{l}\text { foothill yellow-legged } \\
\text { frog }\end{array}$ & None & None & SSC \\
\hline 9 & Aquila chrysaetos & golden eagle & None & None & $\mathrm{FP} \mid \mathrm{WL}$ \\
\hline 10 & $\begin{array}{l}\text { Ammodramus } \\
\text { savannarum }\end{array}$ & grasshopper sparrow & None & None & SSC \\
\hline 11 & Lanius ludovicianus & loggerhead shrike & None & None & SSC \\
\hline 12 & Falco columbarius & merlin & None & None & WL \\
\hline 13 & Antrozous pallidus & pallid bat & None & None & SSC \\
\hline 14 & Falco mexicanus & prairie falcon & None & None & WL \\
\hline 15 & Progne subis & purple martin & None & None & SSC \\
\hline 16 & Pyrgulopsis taylori & San Luis Obispo pyrg & None & None & \\
\hline 17 & $\begin{array}{l}\text { Anniella pulchra } \\
\text { pulchra }\end{array}$ & silvery legless lizard & None & None & SSC \\
\hline 18 & $\begin{array}{l}\text { Oncorhynchus } \\
\text { mykiss irideus }\end{array}$ & $\begin{array}{l}\text { steelhead - } \\
\text { south/central California } \\
\text { coast DPS }\end{array}$ & Threatened & None & SSC \\
\hline 19 & $\begin{array}{l}\text { Corynorhinus } \\
\text { townsendii }\end{array}$ & $\begin{array}{l}\text { Townsend's big-eared } \\
\text { bat }\end{array}$ & None & None & SSC \\
\hline 20 & $\begin{array}{l}\text { Thamnophis } \\
\text { hammondii }\end{array}$ & $\begin{array}{l}\text { Two-striped garter } \\
\text { snake }\end{array}$ & None & None & SSC \\
\hline 21 & Emys marmorata & western pond turtle & None & None & SSC \\
\hline 22 & Lasiurus blossevillii & western red bat & None & None & SSC \\
\hline 23 & Spea hammondii & western spadefoot & None & None & SSC \\
\hline 24 & Elanus leucurus & white-tailed kite & None & None & FP \\
\hline 26 & Myotis yumanensis & Yuma myotis & None & None & \\
\hline
\end{tabular}




\section{APPENDIX C Wildlife Species in the Conservation Area}

Table C.2 Special Status Wildlife Species

Invertebrates

\begin{tabular}{|l|l|l|}
\hline $\begin{array}{l}\text { Vernal pool fairy shrimp } \\
\text { Branchinecta lynchi }\end{array}$ & $\begin{array}{l}\text { VT/-- } \\
\text { chaparral, alkaline flats, terraces, and other } \\
\text { habitats of the central valley, and central and } \\
\text { southern coastal and adjacent inland areas. }\end{array}$ \\
$\begin{array}{l}\text { Pools are small and formed by the collection } \\
\text { of freshwater in sandstone, hard-pan or clay- } \\
\text { pan layer depression, grassy swales, or earth } \\
\text { slumps. }\end{array}$ \\
\hline
\end{tabular}

Fish

\begin{tabular}{|l|l|l|}
\hline $\begin{array}{c}\text { Steelhead trout - South } \\
\text { Central Coast ESU } \\
\text { Onchorhynchus mykiss inideus }\end{array}$ & FT/CSC & $\begin{array}{l}\text { Fast flowing. highly oxygenated, clear cool } \\
\text { streams. }\end{array}$ \\
& & \\
& & \\
\hline
\end{tabular}

\section{Reptiles/Amphibians}

\begin{tabular}{|l|c|l|}
\hline \hline $\begin{array}{l}\text { Southwestern pond turtle } \\
\text { Actinemys marmorata pallida }\end{array}$ & $-/$ CSC & $\begin{array}{l}\text { Permanent or nearly permanent water bodies } \\
\text { in many habitats Uses upland habitat for } \\
\text { nesting. }\end{array}$ \\
\hline $\begin{array}{l}\text { California tiger salamander } \\
\text { (Central Population; Central } \\
\begin{array}{c}\text { Coast Region) } \\
\text { Ambystoma californiense }\end{array}\end{array}$ & FE/CSC & $\begin{array}{l}\text { Breeding habitat consists of large vernal } \\
\text { pools, stock ponds, and seasonal and } \\
\text { perennial ponds and associated grassland } \\
\text { savanna habitat. Upland habitat also } \\
\text { includes active California ground squirrel and } \\
\text { Botta's pocket gopher burrows. }\end{array}$ \\
\hline $\begin{array}{l}\text { Silvery legless lizard } \\
\text { Anniella pulchra pulchra }\end{array}$ & $-/$ CSC & $\begin{array}{l}\text { Prefers open vegetation in chaparral and } \\
\text { scrub habitats with sandy loose soils or } \\
\text { wooded areas with loose soils and leaf } \\
\text { debris. }\end{array}$ \\
\hline
\end{tabular}




\section{APPENDIX C Wildlife Species in the Conservation Area}

\begin{tabular}{|c|c|c|}
\hline $\begin{array}{l}\text { Coast horned lizard } \\
\text { Phrynosoma coronatum } \\
\text { (frontale population) }\end{array}$ & $-/ \mathrm{CSC}$ & $\begin{array}{l}\text { Wide variety of habitats, especially in coastal } \\
\text { scrub communities and along washes with } \\
\text { scattered shrubs for cover. }\end{array}$ \\
\hline $\begin{array}{l}\text { California red-legged frog } \\
\text { Rana aurora draytoniï }\end{array}$ & FT/CSC & $\begin{array}{l}\text { Permanent sources of deep water with } \\
\text { emergent or riparian vegetation. Can use a } \\
\text { variety of habitats. }\end{array}$ \\
\hline $\begin{array}{l}\text { Western spadefoottead } \\
\text { Spea hammondii }\end{array}$ & $-/ \mathrm{CSC}$ & $\begin{array}{l}\text { Grasslands, valley and foothill woodlands } \\
\text { near ephemeral/vernal pools or seasonal } \\
\text { agricultural ponds that are used for } \\
\text { breeding. }\end{array}$ \\
\hline $\begin{array}{l}\text { Coast range newt } \\
\text { Taricha torosa torosa }\end{array}$ & $-/ \mathrm{CSC}$ & $\begin{array}{l}\text { Valley-foothill woodlands, coastal scrub, } \\
\text { chaparral, and annual grassland habitats. } \\
\text { near-slew mevingerstegnantwatef } \\
\text { Breeding occurs in clear streams with } \\
\text { rocks and boulders in central and } \\
\text { southern California, and they breed in } \\
\text { ponds and reservoirs in northern parts of } \\
\text { their range. }\end{array}$ \\
\hline
\end{tabular}

\section{Birds}

\begin{tabular}{|l|l|l|}
\hline $\begin{array}{l}\text { Cooper's hawk } \\
\text { Accipiter cooperii }\end{array}$ & - /CSC & $\begin{array}{l}\text { Woodlands for nesting. Open areas and } \\
\text { human structures for foraging. }\end{array}$ \\
\hline $\begin{array}{l}\text { Golden eagle } \\
\text { Aquila chrysuetos }\end{array}$ & $--/$ CSC, FP & $\begin{array}{l}\text { Cliffs trees, and rocky ledges for nesting. } \\
\text { Grasslands and open country for foraging. }\end{array}$ \\
\hline
\end{tabular}




\section{APPENDIX C Wildlife Species in the Conservation Area}

\section{Birds Continued}

\begin{tabular}{|c|c|c|}
\hline $\begin{array}{l}\text { Ferruginous hawk } \\
\text { Buteo regalis }\end{array}$ & $-/ \mathrm{CSC}$ & $\begin{array}{l}\text { Cliffs, banks, shrublands, and sparse } \\
\text { woodlands for nesting. Open grassland, } \\
\text { sagebrush, agricultural, and desert scrub } \\
\text { habitats for foraging. }\end{array}$ \\
\hline $\begin{array}{l}\text { Yellow warbler } \\
\text { Dendroica petechia brewsteri }\end{array}$ & $-/ \mathrm{CSC}$ & $\begin{array}{l}\text { Riparian habitat, prefers willows, } \\
\text { cottonwoods, aspens, sycamores, and alders } \\
\text { for nesting and foraging. }\end{array}$ \\
\hline $\begin{array}{l}\text { White-tailed kite } \\
\text { Elanus leucurus }\end{array}$ & $-\sqrt{F P}$ & $\begin{array}{l}\text { Woodlands for nesting and open country. } \\
\text { grasslands and marshes for foraging. }\end{array}$ \\
\hline $\begin{array}{l}\text { California homed lark } \\
\text { Eremophila alpestris actia }\end{array}$ & $-/ \mathrm{CSC}$ & $\begin{array}{l}\text { Sparse coastal sage scrub and grasslands } \\
\text { for nesting and foraging. }\end{array}$ \\
\hline $\begin{array}{l}\text { Merlin } \\
\text { Falco columbarius }\end{array}$ & $-\mathrm{ACSC}$ & $\begin{array}{l}\text { Breeds in Alaska and Canada in open } \\
\text { country such as open coniferous } \\
\text { woodland and prairie, and occasionally in } \\
\text { adjacent suburbs. Winters in California in } \\
\text { open woodland, grassland, open } \\
\text { cultivated fields, marshes, estuaries, and } \\
\text { seacoasts. }\end{array}$ \\
\hline $\begin{array}{l}\text { MedinPrairie falcon } \\
\text { Falco mexicanus }\end{array}$ & $-/ \mathrm{CSC}$ & $\begin{array}{l}\text { Cliffs overlooking large areas for nesting. } \\
\text { Open habitats and grasslands for foraging. } \\
\text { Present in California year-round. }\end{array}$ \\
\hline $\begin{array}{l}\text { Bald eagle } \\
\text { Haliaeetus leucocphalus }\end{array}$ & FT/SE, FP & $\begin{array}{l}\text { Large mature trees for roosting and nesting } \\
\text { and large bodies of water for foraging. Nests }\end{array}$ \\
\hline & & near large bodies of water. \\
\hline $\begin{array}{l}\text { Yellow breasted chat } \\
\text { Icteria virens }\end{array}$ & $-/ \mathrm{CSC}$ & $\begin{array}{l}\text { Thickly vegetated riparian habitats near } \\
\text { watercourses for nesting and foraging. }\end{array}$ \\
\hline $\begin{array}{l}\text { Loggerhead shrike } \\
\text { Lanius ludovicianus }\end{array}$ & $-/ \mathrm{CSC}$ & $\begin{array}{l}\text { Coastal sage scrub, riparian scrub, riparian } \\
\text { woodland for nesting. Grasslands and other } \\
\text { semi-open habitats for foraging. }\end{array}$ \\
\hline $\begin{array}{l}\text { Purple martin } \\
\text { Progne subis }\end{array}$ & $-/ \mathrm{CSC}$ & $\begin{array}{l}\text { Woodlands including sycamores, low } \\
\text { elevation coniferous forests, mixed and oak } \\
\text { woodlands for nesting and foraging. Primarily } \\
\text { nests in old woodpecker cavities. }\end{array}$ \\
\hline
\end{tabular}




\section{APPENDIX C Wildlife Species in the Conservation Area}

\begin{tabular}{|l|c|l|}
\multicolumn{2}{l}{ Mammals } \\
\hline $\begin{array}{l}\text { American badger } \\
\text { Taxidea taxus }\end{array}$ & - /CSC & $\begin{array}{l}\text { Open grassland and desert area with friable } \\
\text { soils and a suitable rodent prey base. }\end{array}$ \\
\hline $\begin{array}{l}\text { Pallid bat } \\
\text { Antrozous pallidus }\end{array}$ & - /CSC & $\begin{array}{l}\text { Grasslands, shrublands, and woodlands, but } \\
\text { most common in open, dry habitats with } \\
\text { rocky ledges for roosting. }\end{array}$ \\
\hline $\begin{array}{l}\text { Townsend's big-eared bat } \\
\text { Corynorhinus townsendii }\end{array}$ & - /CSC & $\begin{array}{l}\text { All habitat types except sub-alpine areas. } \\
\text { Requires caves, tunnels, or other areas } \\
\text { suitable for roosting. }\end{array}$ \\
\hline
\end{tabular}

Source: Santa Margarita Agricultural Residential Cluster Subdivision Environmental Impact Report 2008 


\section{San Luis Obispo County Bird List}

Non-native or introduced

\section{Ducks, Geese, and Swans (Anatidae)}

Fulvous Whistling-Duck

_ Greater White-fronted Goose

- Emperor Goose

_ Snow Goose

— Ross's Goose

— Brant

_ Cackling Goose

- Canada Goose

— Trumpeter Swan

_ Tundra Swan

— Wood Duck

- Gadwall

_ Eurasian Wigeon

_ American Wigeon

_ Mallard

_ Blue-winged Teal

- Cinnamon Teal

— Northern Shoveler

_ Northern Pintail

_ Garganey

_ Green-winged Teal

_ Canvasback

— Redhead

_ Ring-necked Duck

- Tufted Duck

— Greater Scaup

_ Lesser Scaup

- Harlequin Duck

- Surf Scoter

_ White-winged Scoter

Black Scoter

_ Long-tailed Duck

_Bufflehead

- Common Goldeneye

_ Barrow's Goldeneye

_ Hooded Merganser

- Common Merganser

_ Red-breasted Merganser

_ Ruddy Duck

New World Quail (Odontophoridae)

Mountain Quail

_ California Quail

\section{Partridges and Turkeys (Phasianidae)}

Chukar

Wild Turkey

\section{Loons (Gaviidae)}

Red-throated Loon

Pacific Loon

_ Arctic Loon

_ Common Loon
Yellow-billed Loon

\section{Grebes (Podicipedidae)}

Pied-billed Grebe

Horned Grebe

- Red-necked Grebe

Eared Grebe

Western Grebe

_ Clark's Grebe

\section{Albatrosses (Diomedeidae)}

Laysan Albatross

_ Black-footed Albatross

_ Short-tailed Albatross

Shearwaters and Petrels (Procellariidae)

Northern Fulmar

Mottled Petrel

Cook's Petrel

Pink-footed Shearwater

Flesh-footed Shearwater

Buller's Shearwater

Sooty Shearwater

Short-tailed Shearwater

Manx Shearwater

Black-vented Shearwater

\section{Storm-Petrels (Hydrobatidae)}

Wilson's Storm-Petrel

Fork-tailed Storm-Petrel

Leach's Storm-Petrel

Ashy Storm-Petrel

Black Storm-Petrel

_ Least Storm-Petrel

\section{Tropicbirds (Phaethontidae)}

Red-billed Tropicbird

_ Red-tailed Tropicbird

\section{Boobies (Sulidae)}

Blue-footed Booby

Brown Booby

_ Red-footed Booby

\section{Pelicans (Pelecanidae)}

American White Pelican

Brown Pelican

\section{Cormorants (Phalacrocoracidae)}

Brandt's Cormorant

Double-crested Cormorant

_ Pelagic Cormorant 


\section{Frigatebirds (Fregatidae)}

Magnificent Frigatebird

Bitterns, Herons, and Allies (Ardeidae)

American Bittern

Least Bittern

- Great Blue Heron

- Great Egret

_ Snowy Egret

— Little Blue Heron

Tricolored Heron

_ Reddish Egret

_ Cattle Egret

- Green Heron

_ Black-crowned Night-Heron

lbises and Spoonbills (Threskiornithidae)

White-faced Ibis

Roseate Spoonbill

Storks (Ciconiidae)

Wood Stork

New World Vultures (Cathartidae)

Turkey Vulture

_ California Condor

Hawks, Kites, Eagles and Allies (Accipitridae)

Osprey

White-tailed Kite

— Mississippi Kite

Bald Eagle

Northern Harrier

Sharp-shinned Hawk

- Cooper's Hawk

Northern Goshawk

- Red-shouldered Hawk

- Broad-winged Hawk )

Swainson's Hawk

_ Zone-tailed Hawk

_ Red-tailed Hawk

_ Ferruginous Hawk

— Rough-legged Hawk

_ Golden Eagle

Caracaras \& Falcons (Falconidae)

Crested Caracara

_ American Kestrel

Merlin

Peregrine Falcon

_ Prairie Falcon
Rails, Gallinules, and Coots (Rallidae)

Yellow Rail

Black Rail

— Clapper Rail

_ Virginia Rail

- Sora

_ Common Moorhen

American Coot

Cranes (Gruidae)

Sandhill Crane

\section{Plovers (Charadriidae)}

Black-bellied Plover

American Golden-Plover

Pacific Golden-Plover

Snowy Plover

Semipalmated Plover

Piping Plover

Killdeer

Mountain Plover

Oystercatchers (Haematopodidae)

_ American Oystercatcher

_ Black Oystercatcher

Stilts and Avocets (Recurvirostidae)

Black-necked Stilt

_ American Avocet

Sandpipers, Phalaropes, and Allies (Scolopacidae)

Spotted Sandpiper

Solitary Sandpiper

Wandering Tattler

_ Greater Yellowlegs

Willet

_ Lesser Yellowlegs

Little Curlew

— Whimbrel

_ Long-billed Curlew

Marbled Godwit

_ Bar-tailed Godwit

_ Ruddy Turnstone

- Black Turnstone

— Surfbird

Red Knot

_ Sanderling

- Semipalmated Sandpiper

Western Sandpiper

_ Red-necked Stint

_ Least Sandpiper

Baird's Sandpiper

Pectoral Sandpiper

_ Sharp-tailed Sandpiper

Dunlin 
Stilt Sandpiper

Buff-breasted Sandpiper

Ruff

_ Short-billed Dowitcher

_ Long-billed Dowitcher

Wilson's Snipe

_ Wilson's Phalarope

_ Red-necked Phalarope

_ Red Phalarope

\section{Gulls, Terns, and Skimmers (Laridae)}

Black-legged Kittiwake

Sabine's Gull

Ivory Gull

_ Bonaparte's Gull

_ Little Gull

— Laughing Gull

_ Franklin's Gull

_ Heermann's Gull

Mew Gull

_ Ring-billed Gull

Western Gull

_ California Gull

Herring Gull

_ Thayer's Gull

_ Glaucous-winged Gull

_ Glaucous Gull

_ Least Tern

- Caspian Tern

- Black Tern

_ Common Tern

_ Arctic Tern

_ Forster's Tern

_ Royal Tern

_ Elegant Tern

_ Black Skimmer

Skuas and Jaegers (Stercorariidae)

South Polar Skua

- Pomarine Jaeger

— Parasitic Jaeger

_ Long-tailed Jaeger

\section{Auks, Murres, and Puffins (Alcidae)}

Common Murre

Pigeon Guillemot

Marbled Murrelet

Xantus's Murrelet

_ Craveri's Murrelet

— Ancient Murrelet

_ Cassin's Auklet

_ Parakeet Auklet

- Rhinoceros Auklet

— Horned Puffin

Tufted Puffin

Pigeons and Doves (Columbidae)
Rock Pigeon

Band-tailed Pigeon

Eurasian Collared-Dove

-White-winged Dove

_ Mourning Dove

Common Ground-Dove

Cuckoos, Roadrunners, and Anis (Cuculidae)

Yellow-billed Cuckoo

_ Greater Roadrunner

\section{Barn Owls (Tytonidae)}

Barn Owl

\section{Typical Owls (Strigidae)}

Flammulated Owl

Western Screech-Owl

Great Horned Owl

Northern Pygmy-Owl

Burrowing Owl

Spotted Owl

- Long-eared Owl

— Short-eared Owl

Northern Saw-whet Owl

\section{Goatsuckers (Caprimulgidae)}

Lesser Nighthawk

Common Nighthawk

Common Poorwill

\section{Swifts (Apodidae)}

Black Swift

Chimney Swift

— Vaux's Swift

_ White-throated Swift )

Hummingbirds (Trochilidae)

Broad-billed Hummingbird

Ruby-throated Hummingbird

_ Black-chinned Hummingbird

Anna's Hummingbird

- Costa's Hummingbird

_ Calliope Hummingbird

Rufous Hummingbird

_ Allen's Hummingbird

\section{Kingfishers (Alcedinidae)}

_ Belted Kingfisher

\section{Woodpeckers and Allies (Picidae)}

_ Lewis's Woodpecker

Acorn Woodpecker

Williamson's Sapsucker 
Yellow-bellied Sapsucker

Red-naped Sapsucker

Red-breasted Sapsucker

_ Nuttall's Woodpecker

- Downy Woodpecker

_ Hairy Woodpecker

- White-headed Woodpecker

_ Northern Flicker

\section{Tyrant Flycatchers (Tyrannidae)}

Olive-sided Flycatcher

- Greater Pewee

_ Western Wood-Pewee

Yellow-bellied Flycatcher

_ Willow Flycatcher

_ Least Flycatcher

Hammond's Flycatcher

_ Gray Flycatcher

_ Dusky Flycatcher

Pacific-slope Flycatcher

- Black Phoebe

— Eastern Phoebe

Say's Phoebe

— Vermilion Flycatcher

_ Dusky-capped Flycatcher

Ash-throated Flycatcher

- Great Crested Flycatcher

_ Brown-crested Flycatcher

_ Sulphur-bellied Flycatcher

_ Tropical Kingbird

— Cassin's Kingbird

_ Western Kingbird

_ Eastern Kingbird

_ Scissor-tailed Flycatcher

\section{Shrikes (Laniidae)}

_ Loggerhead Shrike

\section{Vireos (Vireonidae)}

Bell's Vireo

Yellow-throated Vireo

- Plumbeous Vireo

_ Cassin's Vireo

_ Blue-headed Vireo

— Hutton's Vireo

_ Warbling Vireo

_ Philadelphia Vireo

_ Red-eyed Vireo

_ Yellow-green Vireo

Jays and Crows (Corvidae)

Steller's Jay

— Western Scrub-Jay

_ Pinyon Jay

Clark's Nutcracker

_ Yellow-billed Magpie

- American Crow

_ Common Raven

\section{Larks (Alaudidae)}

Horned Lark

\section{Swallows (Hirundinidae)}

Purple Martin

Tree Swallow

_ Violet-green Swallow

_ Northern Rough-winged Swallow

Bank Swallow

- Cliff Swallow

_ Barn Swallow

\section{Chickadees and Titmice (Paridae)}

Mountain Chickadee

Chestnut-backed Chickadee

Oak Titmouse

\section{Bushtits (Aegithalidae)}

_ Bushtit

Nuthatches (Sittadae)

Red-breasted Nuthatch

White-breasted Nuthatch

_ Pygmy Nuthatch

Creepers (Certhiidae)

Brown Creeper

\section{Wrens (Troglodytidae)}

Rock Wren

_ Canyon Wren

Bewick's Wren

- House Wren

Pacific Wren

- Marsh Wren

\section{Gnatcatchers (Polioptilidae)}

Blue-gray Gnatcatcher

Dippers (Cinclidae)

American Dipper

\section{Kinglets (Regulidae)}

Golden-crowned Kinglet

Ruby-crowned Kinglet 


\section{Leaf Warblers (Phylloscopidae)}

Arctic Warbler

\section{Thrushes (Turdidae)}

Western Bluebird

Mountain Bluebird

Townsend's Solitaire

- Swainson's Thrush

Hermit Thrush

American Robin

_ Varied Thrush

\section{Babblers (Timaliidae)}

Wrentit

\section{Mockingbirds and Thrashers (Mimidae)}

Gray Catbird

Northern Mockingbird

Sage Thrasher

- Brown Thrasher

Bendire's Thrasher

California Thrasher

_ LeConte's Thrasher )

\section{Starlings (Sturnidae)}

European Starling

Wagtails and Pipits (Motacillidae)

Eastern Yellow Wagtail

White Wagtail

_ Red-throated Pipit

_ American Pipit

_ Sprague's Pipit

Waxwings (Bombycillidae)

Cedar Waxwing )

\section{Silky-Flycatchers (Ptilogonatidae)}

Phainopepla

\section{Wood-Warblers (Parulidae)}

Golden-winged Warbler

Tennessee Warbler

- Orange-crowned Warbler

_ Nashville Warbler

Virginia's Warbler

— Lucy's Warbler

— Northern Parula

Yellow Warbler

- Chestnut-sided Warbler

_ Magnolia Warbler

Cape May Warbler
Black-throated Blue Warbler

Yellow-rumped Warbler

Black-throated Gray Warbler

Black-throated Green Warbler

_ Townsend's Warbler

Hermit Warbler

Blackburnian Warbler

_ Yellow-throated Warbler

Grace's Warbler

Pine Warbler

Prairie Warbler

Palm Warbler

Bay-breasted Warbler

_ Blackpoll Warbler

Black-and-white Warbler

American Redstart

Prothonotary Warbler Worm-eating Warbler

- Ovenbird

Northern Waterthrush

Kentucky Warbler

Connecticut Warbler

_ Mourning Warbler MacGillivray's Warbler

Common Yellowthroat Hooded Warbler Wilson's Warbler

Canada Warbler Painted Redstart

Yellow-breasted Chat

\section{Emberizids (Emberizidae)}

Green-tailed Towhee

Spotted Towhee

California Towhee

Cassin's Sparrow

Rufous-crowned Sparrow

American Tree Sparrow

Chipping Sparrow

Clay-colored Sparrow

Brewer's Sparrow

Black-chinned Sparrow

Vesper Sparrow

Lark Sparrow

Black-throated Sparrow

_ Sage Sparrow

_ Lark Bunting

_ Savannah Sparrow

- Grasshopper Sparrow

Nelson's Sparrow

_ Fox Sparrow

Song Sparrow

Lincoln's Sparrow

- Swamp Sparrow White-throated Sparrow

Harris's Sparrow

White-crowned Sparrow

Golden-crowned Sparrow

- Dark-eyed Junco

- McCown's Longspur

_ Lapland Longspur 
Chestnut-collared Longspur

Tanagers, Cardinals, Saltators, and Allies (Cardinalidae)
Hepatic Tanager
- Summer Tanager
- Scarlet Tanager
Western Tanager
_ Rose-breasted Grosbeak
_ Black-headed Grosbeak
_ Blue Grosbeak
_ Lazuli Bunting
_ Indigo Bunting
_ Painted Bunting
_ Dickcissel

\section{Blackbirds (Icteridae)}
Bobolink
Red-winged Blackbird
— Tricolored Blackbird
_ Western Meadowlark
Yellow-headed Blackbird
_ Rusty Blackbird
_ Brewer's Blackbird
_ Common Grackle
_ Great-tailed Grackle
_ Brown-headed Cowbird
- Orchard Oriole
_ Hooded Oriole
_ Bullock's Oriole
_Baltimore Oriole
_ Scott's Oriole

Fringilline Finches and Allies (Fringillidae)

Purple Finch

_ Cassin's Finch

_ House Finch

_ Red Crossbill

_ Pine Siskin

_ Lesser Goldfinch

- Lawrence's Goldfinch

_ American Goldfinch

_ Evening Grosbeak

Old World Sparrows (Passeridae)

House Sparrow 


\section{APPENDIX D Williamson Act and Property Taxes}

The tables below show how Proposition 13 and Williamson Act property values and subsequent tax rates are assessed. This is an example used to demonstrate these differences and do not reflect the value of any particular property within the Conservation Area. Property values and potential income may vary depending on a number of factors including land use, size of property and number of improvements.

\begin{tabular}{|l|r|}
\hline \multicolumn{2}{|c|}{ Proposition 13 Taxable Property Value } \\
\hline Total acreage & 1000 \\
\hline approximate land value/acre of rangeland & $\$ 2,250.00$ \\
\hline Land Value & $\$ 2,250,000.00$ \\
\hline Improvements & $\$ 250,000.00$ \\
\hline Total Property Value & $\$ 2,500,000.00$ \\
\hline
\end{tabular}

\begin{tabular}{|l|r|r|}
\hline \multicolumn{4}{|c|}{ Billable Tax Rates Under Proposition 13 } \\
\hline Tax & Rate per \$100 (\%) & \multicolumn{1}{c|}{ Total Property Tax } \\
\hline Proposition 13 rate & 2 & $\$ 50,000.00$ \\
\hline State Water Project & 0.0029 & $\$ 72.50$ \\
\hline ATAS Unif Override & 0.0975 & $\$ 2,437.50$ \\
\hline Assessed Property Tax & 2.1004 & $\$ 52,510.00$ \\
\hline
\end{tabular}

\begin{tabular}{|l|r|}
\hline \multicolumn{2}{|c|}{ Restricted/Williamson Act Taxable Land Value } \\
\hline Land Value (based on potential income) & $\$ 150,000.00$ \\
\hline $\begin{array}{l}1 \text { acre homesite parcel (average area value } \\
\text { when home was sold) w/ } \% \text { annual tax } \\
\text { adjustment under prop 13 }\end{array}$ & $\$ 76,500.00$ \\
\hline $\begin{array}{l}15 \text { acre vineyard (@\$966/ton with about } 9 \\
\text { tons per acre) }\end{array}$ & $\$ 130,410.00$ \\
\hline Improvements & $\$ 250,000.00$ \\
\hline Total Property Value & $\$ 606,910.00$ \\
\hline
\end{tabular}

\begin{tabular}{|l|r|r|}
\hline \multicolumn{3}{|c|}{ Billable Tax Rates under Restricted Land Values } \\
\hline Tax & \multicolumn{1}{|c|}{ Rate per \$100 (\%) } & \multicolumn{1}{c|}{ Total Property Tax } \\
\hline Proposition 13 rate & 2 & $\$ 12,138.20$ \\
\hline State Water Project & 0.0029 & $\$ 17.60$ \\
\hline ATAS Unif Override & 0.0975 & $\$ 591.74$ \\
\hline Assessed Property Tax & 2.1004 & $\$ 12,747.54$ \\
\hline
\end{tabular}




\section{APPENDIX E Santa Margarita Proposed Development}

Figure E.1 Proposed Agricultural Residential Cluster Subdivision on Santa Margarita Ranch

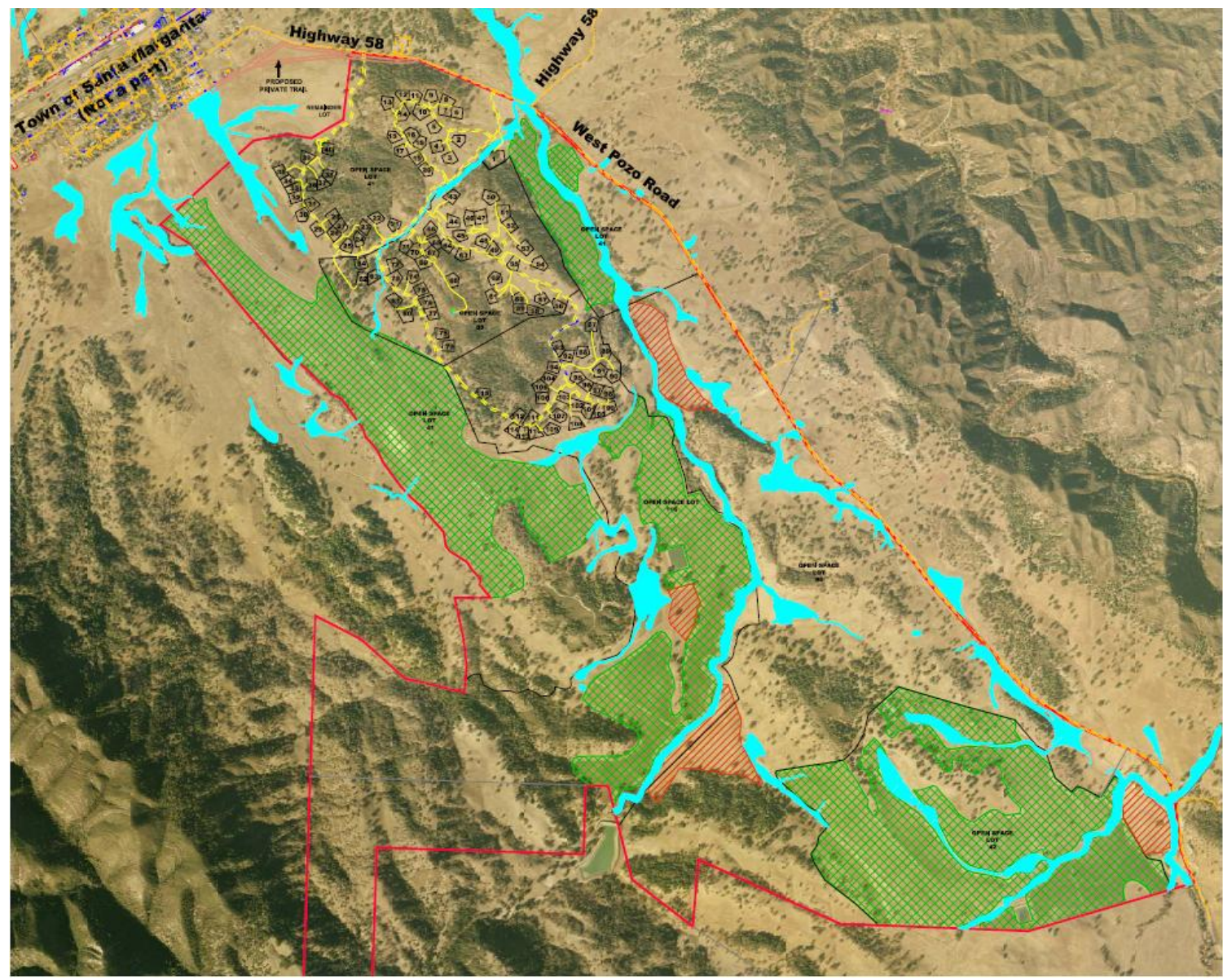

Source: EDA Design Professionals June 2006 


\section{APPENDIX F Example Ranch Financial Inputs and Outputs}

These figures are based on the University of California Cooperative Extension's "Sample Costs for Beef Cattle" (2008) as well as from the rancher/landowner interviews that were conducted for this project. These figures are meant to demonstrate the cost inputs, available resources and income generated from a 100 head of cattle cow-calf operation. Cost figures are only meant to be an example and do not fully represent the breadth of variability associated with the ranching industry nor do these figures represent any particular individual ranching operation. Cost inputs are designed to emulate typical ranching costs associated with ranching operations in the Upper Salinas Watershed. The relatively low financial returns suggests why some ranchers/ranching families make particular land use decisions such as enter into conservation agreements, subdivide their land and sell it off to developers, and/or diversify their agricultural products. These decisions are often supplementary to cattle ranching whose narrowing profit margins are causing shifts in land uses.

\begin{tabular}{|lr|}
\hline \multicolumn{2}{|c|}{ Livestock Logistics (on a 1,000 acre property) } \\
\hline Available Rangeland Acres & 800 \\
\hline Cow-calf pairs & 100 \\
\hline $\begin{array}{l}\text { Average acreage needed for the operation (does } \\
\text { not include non-birthing cows and steers) }\end{array}$ & 11.5 \\
\hline $\begin{array}{l}\text { Total acres need for cow-calve rearing } \\
\text { (anywhere between 6 and 17 depending on } \\
\text { forage availability) }\end{array}$ & 1150 \\
\hline Cows in herd & 100 \\
\hline Birthing success rate (\%) & 95 \\
\hline Calves born to herd & 95 \\
\hline
\end{tabular}

\begin{tabular}{|l|l|}
\hline \multicolumn{2}{|c|}{ Cow-Calf Operations Calendar } \\
\hline Month & Operation \\
\hline September to December & Calving \\
\hline November to April & Winter Range \\
\hline December to February & Breeding \\
\hline May to October & Irrigated Pasture \\
\hline March & Cull Cows Sold \\
\hline March & Cull Bulls Sold \\
\hline May to October & Calves Sold \\
\hline September & Yearling Heifers Sold \\
\hline
\end{tabular}




\section{APPENDIX F Example Ranch Financial Inputs and Outputs}

\begin{tabular}{|c|c|c|c|}
\hline Operating Costs & Cost/Unit & Cost/Head & $\begin{array}{l}\text { Total } \\
\text { Value } \\
\end{array}$ \\
\hline Mineral Supplements & 0.39 & $\$ 15.60$ & $1,560.00$ \\
\hline Hay (stock quality) & $\$ 0.10$ & $\$ 100.00$ & $10,000.00$ \\
\hline Salt Supplement & $\$ 0.12$ & $\$ 4.00$ & 400.00 \\
\hline Winter Pasture & $\$ 80.00$ & $\$ 80.00$ & $8,000.00$ \\
\hline Brand Inspection & $\$ 1.05$ & $\$ 1.05$ & 105.00 \\
\hline Marketing Order Promo (Checkoff) & $\$ 1.00$ & $\$ 1.00$ & 100.00 \\
\hline Freight/trucking & $\$ 30.00$ & $\$ 30.00$ & $3,000.00$ \\
\hline Marketing & $\$ 10.50$ & $\$ 10.50$ & $1,050.00$ \\
\hline Horse (shoeing, vet, feed) & $\$ 90.00$ & $\$ 3.60$ & $1,800.00$ \\
\hline Yearling Bulls Purchased & $\$ 2,058.00$ & $\$ 27.44$ & $2,744.00$ \\
\hline Veterinary Medicine & $\$ 1.00$ & $\$ 30.00$ & $3,000.00$ \\
\hline Vehicles (fuel and repair) & $\$ 1.00$ & $\$ 31.71$ & $3,171.00$ \\
\hline Equipment (repair) & $\$ 1.00$ & $\$ 1.77$ & 177.00 \\
\hline Interest on operating capital $(6.75 \%)$ & $\$ 0.07$ & $\$ 15.95$ & $1,595.00$ \\
\hline Total Operating Costs & & & $36,702.00$ \\
\hline \multicolumn{4}{|l|}{ Ownership Costs } \\
\hline Taxes and Insurance & & $\$ 15.00$ & $\$ 1,500.00$ \\
\hline Office & & $\$ 11.67$ & $\$ 1,167.00$ \\
\hline $\begin{array}{l}\text { Capital Recovery (Livestock, } \\
\text { Equipment) }\end{array}$ & & $\$ 73.38$ & $\$ 7,338.00$ \\
\hline Total Ownership Costs & & & $\$ 10,005.00$ \\
\hline Total Cost & & & $\$ 46,707$ \\
\hline
\end{tabular}

\begin{tabular}{|c|c|c|c|c|}
\hline & $\begin{array}{c}\text { Total Number } \\
\text { of Animals in } \\
\text { Herd }\end{array}$ & CWT each & $\begin{array}{l}\text { Cost per Cwt unit } \\
\text { (2007 average } \\
\text { market price) }\end{array}$ & Total Value \\
\hline Cows in Herd & 100 & & & \\
\hline Calves Sold & 85 & & & \\
\hline Steer calves & 43 & 6.38 & $\$ 103.62$ & $\$ 28,427.11$ \\
\hline Heifer calves & 33 & 6.15 & $\$ 92.29$ & $\$ 18,730.26$ \\
\hline $\begin{array}{l}\text { Yearling } \\
\text { heifers }\end{array}$ & 10 & 8.25 & $\$ 90.77$ & $\$ 7,488.53$ \\
\hline Cull Bulls & 1 & 18 & $\$ 55.10$ & $\$ 991.80$ \\
\hline Cull Cows Sold & 10 & 12.5 & $\$ 47.00$ & $\$ 5,875.00$ \\
\hline Total Value & & & & $\$ 61,512.69$ \\
\hline
\end{tabular}




\section{APPENDIX G Rancher Conservation Values}

\section{Rancher Values and Challenges}

Three landowners that own property and operate a cattle ranching operation within the Conservation Area were interviewed to understand the local needs, challenges, methods of communication, thoughts on stewardship and criteria for their willingness to work with organizations such as the Conservancy on conservation projects. A big component of whether or not projects work is the ability to establish solid working relationships with landowners. In order to establish relationships, there must be mutual trust and understanding from all stakeholders involved. For example unwilling landowners would make it extremely difficult, if not impossible to accomplish essential projects on their property. On the other hand, organizations unwilling to understand landowner needs and work to meet those needs could potentially marginalize landowners and their desire to implement stewardship measures.

The landowner interviews were to gain some understanding for the potential to establish working partnerships with landowners that would be mutually beneficial and entirely voluntary on the landowner's part. Three ranchers were interviewed. Of the three, all the ranchers considered it a responsibility to be good stewards to the land. Of them, to varying degrees, to incorporate management practices that are supportive of landscape sustainability including, fencing off riparian areas, rotating cattle on and off of particular areas to prevent overgrazing as well as prevent the proliferation of invasive species, utilizing stock ponds and water troughs to keep cattle out of riparian areas. Two were in the process of developing conservation easements for all or part of their land. 


\section{APPENDIX G Rancher Conservation Values}

\section{Rancher Land and Conservation Values}

Cattle ranching has been a staple in American culture representing a particular lifestyle rooted in self reliance and dependence on the land and associated natural resources. Despite socioeconomic issues growth and regulatory pressures, the people who work in the industry and on the land love what they do. This resonated both through the literature as well as the interviews that were conducted. Hendrick (2007) states, "the reality is that most ranchers are land rich and cash poor" (2007 pg 105). Despite the decreasing profit margins, ranching families work hard in order to preserve their way of life. According to Torell et al. (2001) both ranch income and a desirable quality of life are essential components of the ranching lifestyle, but both the interviews and literature review reveal a much more complex and multidimensional rationale for the choices that ranching families make to maintain their lifestyle as well as to demonstrate the importance of their way of life. The love of their land and the lifestyle that they choose to live outweigh the increasingly lower income received from their ranching operation.

The difference in background, degree of dependence on the ranching operation for income, amount of land owned and length of time the land has been in the family all play a factor into the ranching values and the subsequent decisions that are made regarding the operation and the rangeland property (Huntsinger et al. 2010). For example in a survey by Huntsinger et al. (2010) in 2004, the education level of ranchers operating on hardwood rangeland in California grew between 1985 and 1992 from 50 percent to 60 percent, while the consultation from agencies and non-profits regarding ecosystem services also increased. The size of the private rangeland also indicated that the larger the acreage the more likely the landowner is to participate in voluntary conservation agreements. There is a correlation between the different demographic and 


\section{APPENDIX G Rancher Conservation Values}

background characteristics i.e. level of education and the likelihood that a rancher would voluntarily participate in consultation or agreements related to conservation practices on the land. Despite the variable demographic characteristics, ranchers overwhelmingly consider the importance of being good stewards of the land and feel a moral obligation to protect resources (Huntsinger et al. 2010, Hendrick 2007, Jackson-Smith et al. 2005, Liffmann et al 2000).

The following sections discuss rancher values in terms of both why ranching is important to them as well as how and to what degree conservation and stewardship are part of their value system. As the ranching industry becomes less profitable for ranchers, it is also important to discuss rancher's perceived threats to their operation and lifestyle.

\section{Value in Ranching}

As profits made from cattle ranching become increasingly marginal, it is important to understand why people continue to work in the business. Torell and Kincaid (1996) state that rancher's quality of life values are realized as land prices rise and the agricultural operation cannot explain the motives for continued ranching. Studies suggest that ranchers operate under a different economic model than that of profit maximization under the capitalism model (Hendrick 2007; Jackson-Smith et al 2005; Torel et al. 2001; Pope 1988; Pope 1987; Martin 1966). Understanding typical economic drivers is typically done by making assumptions regarding a minimum rate of return and through economic modeling techniques estimating if variable inputs will drop the rate of return below the minimum threshold (Torell et al. 2001). According to Torell et al (2001), utilizing this method to understand the western ranching industry, any minimum investment returns would preclude most ranching operations from being in 


\section{APPENDIX G Rancher Conservation Values}

business. This point stresses the value of the quality of life motive indicated in much of the socioeconomic research on western ranching operations (Torell et al. 2001; Pope 1988; Pope 1987; Martin 1966). The variability of ranching operations and the level of dedication to maintaining the lifestyle of individual ranchers are the only way to estimate ranching viability (Torell et al 2001; Jackson-Smith et al 2005, Huntsinger et al. 2010). As a result many studies have attempted to quantify and understand how the quality of life attributes contribute to rancher motivations and as an economic driver. In 1995, a survey of California ranchers operating on oak woodlands, the reason for ranching was "living near natural beauty". Ranchers also stated that "feeling close to the earth" and that living on a ranch was a good place to "raise a family"(Huntsinger et al. 1997). Other reasons included the ranching lifestyle, sense of community, family and neighbors. Many landowners and ranch operators believe that ranching isn't just a job, but a way of life and part of a deeply rooted heritage and provides a motivational driver to continue the lifestyle (Pal 2008).

In interviews with ranchers in the central Sierra Nevada range, Hendrick (2007) stated that a primary reason for the continuation of their ranching operations was emotional rather than economic. Whether it was working on the land, nostalgic thoughts of ranching as a child, and the variation of the work are all part of an important ranching experience (Hendrick 2007). These attributes help to explain the quality of life feature that seems to be so important to the ranching community. The following table $\mathrm{G}-1$ is from a survey that Huntsinger et al. (2010) collected from ranching families across California who operated on oak hardwood rangelands demonstrates the variety of reasons why ranchers continue operating on their land.

Table G-1 Landowners reason for continuing their ranching operation. 


\section{APPENDIX G Rancher Conservation Values}

\begin{tabular}{|c|c|c|c|c|}
\hline \multirow[b]{2}{*}{ Factors } & \multicolumn{3}{|c|}{ Landowners (\%) } & \multirow[b]{2}{*}{$\begin{array}{l}P\left(\chi^{2}\right), \mathrm{df}=2, \\
1985 \text { vs. } 2004\end{array}$} \\
\hline & $\begin{array}{c}1985 \\
(n=126)^{1}\end{array}$ & $\begin{array}{c}1992 \\
(n=115)^{1}\end{array}$ & $\begin{array}{c}2004 \\
(n=98)^{1}\end{array}$ & \\
\hline \multicolumn{5}{|c|}{ I wanted to live near natural } \\
\hline beauty & 46 & 60 & 71 & 0.00 \\
\hline Job opportunities & 21 & 19 & 10 & 0.09 \\
\hline To get away from city life & 39 & 41 & 54 & 0.09 \\
\hline \multicolumn{5}{|l|}{ So I could have a different } \\
\hline lifestyle & 29 & 35 & 48 & 0.00 \\
\hline Recreational opportunities & 31 & 30 & 43 & 0.03 \\
\hline It is cheaper to live here & 9 & 12 & 10 & $n s^{2}$ \\
\hline Family business or property & 55 & 57 & 48 & ns \\
\hline \multirow{2}{*}{\multicolumn{5}{|c|}{$\begin{array}{l}\text { Hunting and fishing-2004 } \\
\text { only }\end{array}$}} \\
\hline & & & & \\
\hline View wildlife-2004 only & - & - & 45 & $m z^{2}$ \\
\hline
\end{tabular}

The lifestyle and operation are an important legacy to many family owned ranches that some would like to preserve for family members of future generations (Huntsinger et al. 2010). Reinvestment in the property and operation is a critical component in ensuring the preservation of not only the land, but the lifestyle.

Reinvestment is not just a matter of financial capital, but also time, effort and the institutional knowledge on the part of the rancher which is why there is a big reliance on ranch succession to future generations.

Ranch succession is important to the continued quality of life value of a ranch. For example, a child growing up on the ranch would be exposed to the lifestyle, provide some of the necessary tasks and labor, get to know the work involved, landscape attributes and the rationale behind management decisions (Hendrick 2007). This ensures continuity in the family enterprise. This institutional knowledge is only important if the successor is invested emotionally and physically in both the operation and the land (Steve Sinton Personal Interview 2011 and Hendrick 2007). Those values and knowledge necessary to continue a successful ranching enterprise are therefore 


\section{APPENDIX G Rancher Conservation Values}

reinvested in the next generation or rancher in order to provide for a sustainable ranching operation as well as proper stewardship of the landscape.

As mentioned earlier, the size of the property often determines the set of values associated with the particular landowner. Generally family ranchers with larger properties produce livestock, operate a family business, live on the property year-round, are more likely to participate in voluntary land conservation programs and have stronger and more favorable anti-regulation opinions (Huntsinger et al 2010). Landowners with smaller acreages, an increasing demographic, do not produce or sell livestock, but may raise livestock as a hobby and are generally more receptive to conservation oriented regulations. These landowners have generally owned their land for less time and may or may not live year-round on site. The reasons for these landowners to live on rangeland is to enjoy the natural scenery and to get away from the hustle and bustle of urban life (Huntsinger et al 2010).

\section{Choice in Land Management Practices}

Land management is the process, practice and programs by which the landowners, such as ranchers utilize to maintain the land. For landowners who depend on the land for their income, managing resources sustainably is a critical part of their operation. Jackson-Smith et al. (2005) surveyed ranchers in Utah and Texas and found that while the demographic characteristics and rancher's perceptions of property rights differed, one consistency was that ranchers had a deeply engrained moral obligation to practice good stewardship on the land they live and work on. Many ranchers/large parcel landowners believe that ranching is important to protect and conserve the ecosystem functions (Huntsinger et al 2010). Despite the traditional disagreements between the ranching community and the environmental community over land 


\section{APPENDIX G Rancher Conservation Values}

management, the one shared goal that is more and more coming to fruition is the common goal of landscape conservation and sound stewardship. Ranchers know the costs associated with the business they are in as well as the natural resources their business consumes (Rowe et al. 2001; Sulak and Huntsinger 2002). In many reports on ranching motives, profit-making rates rank consistently low as a motivation for ranching whereas many ranchers have stated that a strong motivation for ranching and land management decision-making is the protection of ecosystem functions and providing beneficial ecosystem services (Smith and Martin 1972; Bartlett et al. 1989; Huntsinger and Fortmann 1990; Liffmann et al. 2000; Rowe et al. 2001; Torell et al. 2001; Gentner and Tanaka 2002; Huntsinger et al 2010).

Gosnell and Travis (2005) and Campos et al. (2009) and Huntsinger et al (2010) reported that landowners with values associated with the long-term sustainability of their ranching operation and property tended to be more active in conservation management on their property. A rancher's tie to the land means that they are entrusted to its care and have an appreciation and respect for it. (Pal 2008). A survey taken by Liffmann et al. (2000) found that land and operation management priorities for most ranchers across California equated to improving livestock quality, increasing production, improving of the quality and amount of available forage for livestock, ensuring soil stability and improving wildlife habitat. Many of these landowners participated in some form of land conservation.

While many ranchers, to some degree rely on federally owned rangeland, often to supplement their privately owned rangeland, most believe that private lands are better managed (Liffmann et al. 2000). In a survey by Jackson-Smith et al (2005) over 90 percent of rancher respondents agreed that there is a responsibility to be good stewards of the land that they own or operate on. Seventy-five percent of the respondents felt that 


\section{APPENDIX G Rancher Conservation Values}

it was their obligation to leave the land in a better condition than when they attained it. However, all of the surveys demonstrated a strong resistance to regulatory controls over natural resources located on private lands (Jackson-Smith et al 2005; Huntsinger et al. 2010; Liffmann et al 2000. Even if the use of the property causes damage to the resources (Jackson-Smith et al 2005). Ultimately, many ranchers believe it is their obligation "to balance their individual freedoms against the impacts of their actions for the greater good of society" (Jackson-Smith et al 2005).

\section{Ranching Communication}

Many ranchers enjoy camaraderie and sense of community associated with ranching (Huntsinger et al. 2010). As such, it important to recognize the information inputs that ranchers utilize in order to help make better management decisions. In the survey by Liffmann et al (2000), most ranchers preferred to get their information and help from other ranchers and family members. When asked about how innovative land management and ranching techniques were incorporated into a particular ranchers operation, a Central Coast rancher stated during an interview, that he received most of the information from the University of California (UC) Extension Services and Natural Resource Conservation Service (NRCS) workshops (Personal interview with Steve Sinton 2011). The rancher then discussed how most of the ranching community does not actively attend these seminars and workshops and that the "same hand full of ranchers" are the ones that attend the meetings. Other information sources include the local Cattlemen's Association that hosts both ranching community events and information sessions for members. While the values are essential to understand the landowner's long-terms goals, it is also important to understand the information input networks that help to inform and re-enforce or change value systems. 


\section{APPENDIX G Rancher Conservation Values}

\section{Ranchers Perceived Challenges}

Ranchers and ranching communities have strong ties to their land and their lifestyle. Large landowners who depend on the land for their income have several perceived threats that they feel limit their ability to operate on the land and continue their way of life. The traditional feud between ranchers, government agencies and environmentalists has caused an imbedded mistrust between groups, particularly ranchers, whose livelihood is not only the central focus, but also at stake.

Since many of the ways in which cattle ranching operations are managed are passed from one generation to another, many ranchers are threatened by government regulation and control over land management practices because of the perceived loss of personal freedom as well as the ability to continue land management operations that have been suitable to the landowner for generations. An overall trend in ranching sentiments is that the use of natural resources on private land does not and should not necessitate receiving permission from any level of government (Huntsinger et al. 2010 and Hendrick 2007). The biggest fear amongst the ranching community is being overregulated (Huntsinger et al. 2010; Jackson-Smith et al. 2005; Torell et al 2001; Sulak and Huntsinger 2002; Rowe et al. 2001; Liffmann et al. 2000). Specific threats from regulation include wilderness designations' the Endangered Species Act; closure of open range; raising grazing fees on public lands; increasing recreational access to public lands; statewide, regional and local planning efforts; and other environmental regulations i.e. water quality standards (Liffmann et al. 2000) However, according to the survey by Huntsinger 2010, some ranchers feel that regulation with adequate compensation and with consultation from the landowner is acceptable. The threat of over regulation can also mean the loss of the opportunity to develop the land as the 


\section{APPENDIX G Rancher Conservation Values}

rancher sees fit, which is why ranchers perceive regional and local land use planning as a threat to their rights to their property (Liffmann et al. 2000).

Other perceived threats that ranchers may see as a reason to quit ranching are that they feel there is societal hostility towards the ranching industry, trespassing on private land, animal rights, environmentalism and urbanization (Liffmann et al 2000). Vandalism and theft as threats to ranching can be tied to urbanization. Both vandalism and trespassing increase as areas surrounding the ranching community become more urbanized (Liffmann et al 2000). Despite the importance of the quality of life as a motivating factor to continue ranching, there is an economic threshold that many ranchers consider a threat. Therefore, the ranching industry has an economic threshold that differs from rancher to rancher based on location and local market specific dynamics. As a result, unless there is a vast improvement in investment returns, ranchers might be forced to look elsewhere for a source of income (Liffmann et al 2000).

A threat that is being analyzed by researchers and academics is the issue called the "impermance syndrome". Coined by David Berry in 1978, it is essentially the loss of agricultural land near urban areas as urban pressure is being placed on farmers and ranchers, who then lose interest in their trade in the anticipation of urban development (Berry 1978). The issue becomes more relevant as ranchers and their kin take off-ranch jobs to supplement the ranching operation. With the need to be more reliant on offranch income, the probability of an increasing loss of interest in the ranching business increases.

The legitimate concerns regarding the potential threats to their livelihood are being realized as private rangeland and ranching operations are increasingly making way for other types of development. The loss of landowners invested in the land that were obligated to be good stewards of the landscape results in the loss in the 


\section{APPENDIX G Rancher Conservation Values}

institutional knowledge required to provide adequate protection of critical ecosystem functions.

\section{Conclusions}

Hendrick (2007) stated that ranching is a culture adapted to nature. In many of the literature reviews and interview responses there is some obvious overlap in not only a desire, but an obligation to protect the landscape. Ranchers overwhelmingly have shown that economic gain is not the primary reason for being a rancher. While there are many reasons to love what they do, most ranchers love their land, love working outside and know that it is in their best interest to protect it. Many believe that it is important for ranching families to be good stewards of the land in order to ensure a sustainable operation as wel as to protect the intrinsic and ecosystem service value that landscape protection provides. Many of the anthropological, economic and sociological studies on ranching communities speak of the community as a unified entity i.e. statewide, or nationwide, suggesting that the values and challenges that ranchers face and the reason behind their decision-making with regard to their management techniques is uniform. However, a study by Jackson-Smith et al. (2005) of 4 counties in rural Utah and Texas shows that while there are overarching rancher values such as providing good stewardships and love for their lifestyle, local perspectives, values and challenges vary across scales. This report has utilized a collection of data from different scales, including interviews of ranchers and property owners within the Conservation Area in order to draw connections between local, state, and national ranching trends and the values and challenges ranchers face at the local level.

Understanding why ranching is important to ranching families is important because the values of landowners towards their land and lifestyle offer insight which can 


\section{APPENDIX G Rancher Conservation Values}

lead to connections between landowner values and potential conservation tools.

Appropriate conservation tools can then be employed to help landowners meet their long-term goals.

\subsection{Literature Cited}

Bartlett, E.T., R.G. Taylor, J.R. McKean, J.G. Hof. (1989). Motivation of Colorado Ranchers with Federal Grazing Allotments. Journal of Range Management. 42 (6).

Berry, David. (1978). Effects of Urbanization on Agricultural Activities. Growth and Change Vol 9 issue 3, pp 2-8.

Campos, P. J., L. Oviedo, A. Caparros, L. Huntsinger, and I. Coelho. (2009). Contingent valuation of woodland-owners private amenities in Spain, Portugal, and California. Rangeland Ecology \& Management 2(3):240-252.

Gentner, B.J., J.A. Tanaka. (2002). Classifying Federal Public Land Grazing Permittees. Journal of Range Management 55: 2-11.

Gosnell, H. and W.R. Travis. 2005. Ranchland ownership dynamics in the Rocky Mountain West. Rangeland Ecology and Management 58:191-198.

Hendrick,K.D. (2007) Our Way of Life: Identity, Landscape, and Conflict. Ph.D. Thesis. University of California. Riverside.

Huntsinger, L., Johnson, M., Stafford, M. and J. Fried. 2010. California Hardwood Rangeland Landowners 1985 to 2004: Ecosystem services, production, and permanence. Rangeland Ecology and Management.

Huntsinger, L., L. Buttolph, P. Hopkinson. (1997). Ownership and management changes on California's Hardwood rangelands, 1985-1992. Journal of Range Management 50: 423-430.

Huntsinger, Lynn and Fortmann, Louise P. (1990). California's Privately Owned Oak Woodlands: Owners, Use and Management. Journal of Range Management. 43 (2): 147-152.

Jackson-Smith, D., U. Kreuter, \& R. Krannich. (2005). Understanding the multidimensionality of property rights orientations: Evidence from utah and texas ranchers. Society and Natural Resources, 18(7), 587-610. 


\section{APPENDIX G Rancher Conservation Values}

Liffmann, Robin H; Huntsinger, Lynn; Forero, Larry C. (2000) To Ranch or Not to Ranch: Home on the Urban Range? Journal of Range Management 53 pp. $362-370$

Martin, W.E. (1966). Relating Ranch Prices and Grazing Permit Values to Ranch Productivity. Journal of Range Management 19: 248-252.

Pal, Meera (February 25, 2008). Meanwhile, They're Going Green Back at the Ranch. Contra Costa Times (Walnut Creek, CA).

Pope, C.A. (1987). More than Economics Influences Allocation of Rangeland Resources. Choices. Fourth Quarter: 24-25

Pope, C.A. (1988) Romance of Rangeland Resource Management. Rangelands 10:168-170.

Smith, A.H., W.E. Martin. (1972). Socioeconomic Behavior of Cattle Ranchers, with Implications for Rural Community Development in the West. American Journal of Agricultural Economics. 54(2).

Torell, Allen L.; Rimbey, Neil R.; Tanaka, John A.; Bailey, Scott A. (2001). The Lack of a Profit Motive for Ranching Implications for Policy Analysis.

Torell, Allen, L. and M.E. Kincaid. 1996. Public land policy and the market value of New Mexico ranches, 1979-1994. J. Range Manage. 49:270-276.

Rowe, Helen I.; Bartlett E.T.; Swanson Louis E. Jr. (2001). Ranching motivations in 2 Colarado counties. Journal of Range Management 54: 314-321 July 2001.

Sulak, A. and Huntsinger, L. (2002). Sierra Nevada grazing in transition: a report to the Sierra Nevada Alliance, California Cattlemen's Association, and the California Rangeland Trust. Sierra Nevada Alliance, Lake Tahoe, California. Available from http://www.sierranevadaalliance.org (accessed January 2011). 


\section{Appendix H Steelhead Survey Maps}

Figure H.1 Current and historical steelhead distribution

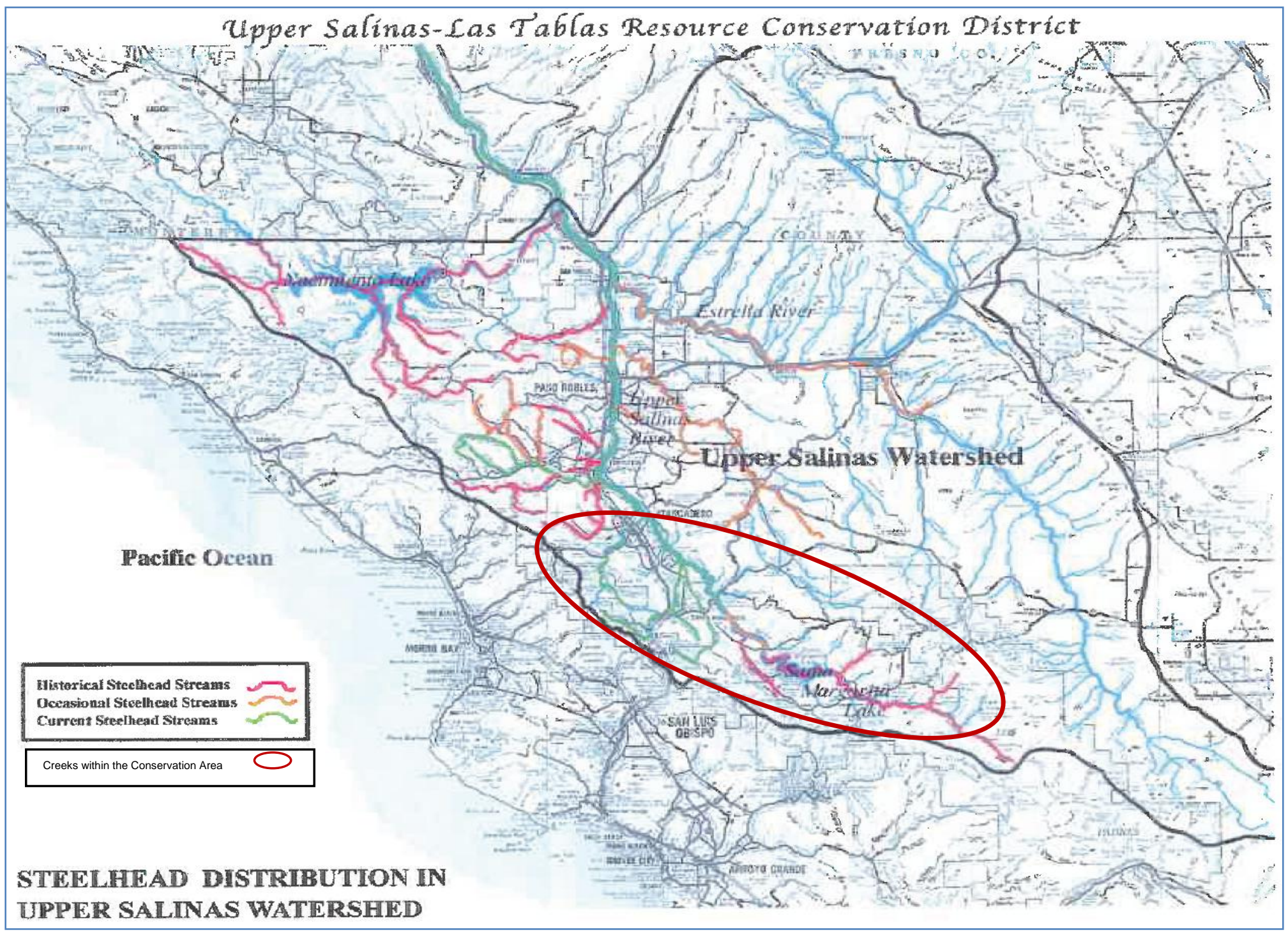




\section{APPENDIX H Steelhead Survey Maps}

Figure H.2 California Department of Fish and Game Survey of Atascadero Creek and several of its tributaries for steelhead presence and available habitat. Below is a map of the areas surveyed.

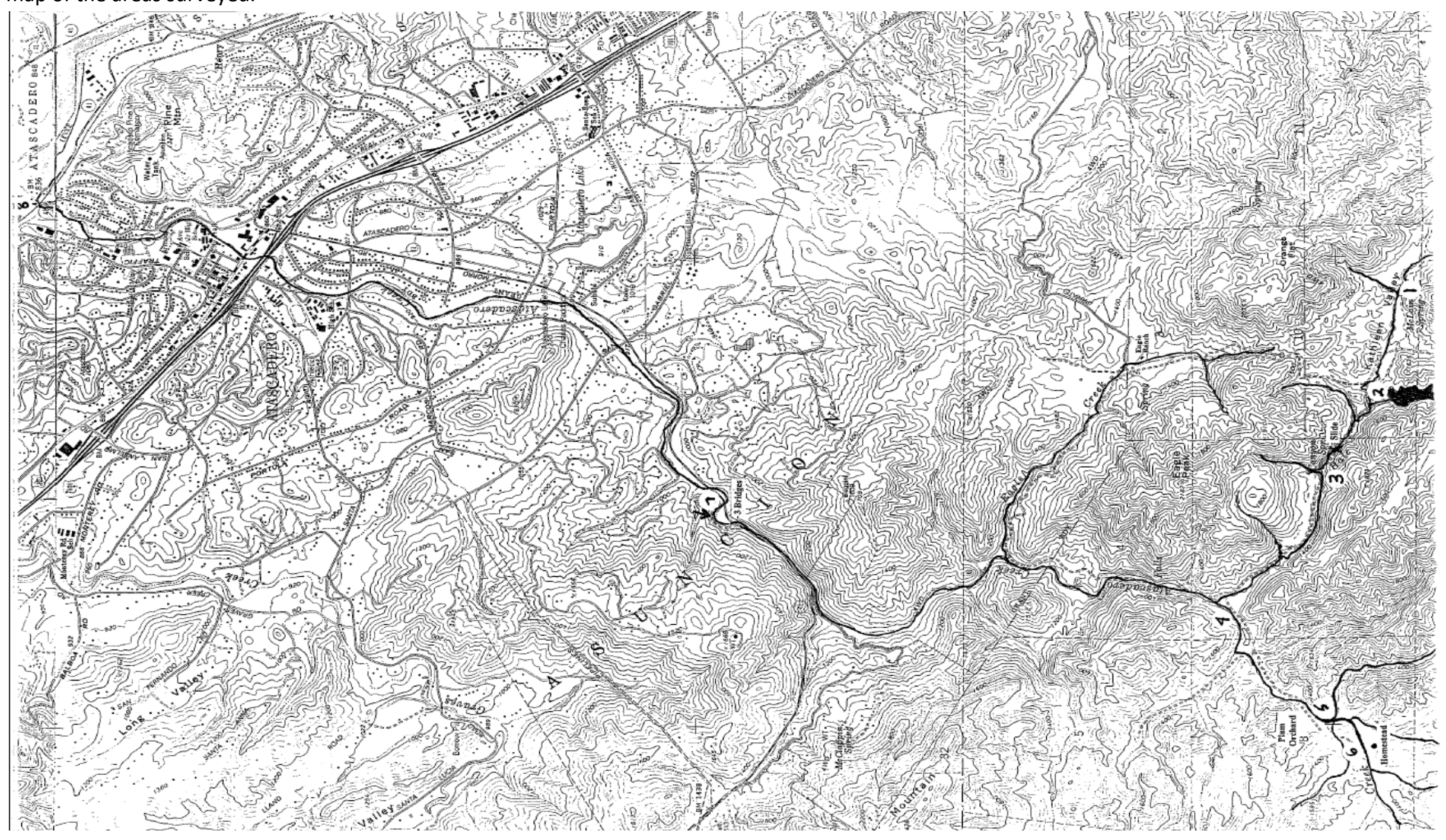

Source: DFG Atascadero Creek Stream Survey 2000 


\section{APPENDIX I Goals, Objectives, Actions and Descriptions}

This section contains further descriptions and illustrations of the action items outlined in Chapter Five including recommended actions for pursuing conservation agreements, land management and commonly used restoration techniques. Many of the actions emphasized support the three primary conservation strategies meant to protect ecological resources and help maintain and/or increase ranch viability. These strategies are described below.

\section{Conservation Agreements}

The long-term health of the Upper Salinas Watershed Conservation Area is dependent upon coordinated efforts that support land protection. There are many ways in which land conservation is achieved including land use controls such as general plan and zoning requirements. Other methods include incentive-based mechanisms such as land purchases, Williamson Act contracts and conservation easements. Due to the large size and feasibility of incentive based programs in the region, traditional land use controls and proper enforcement of existing regulations provide the primary protection within the Conservation Area. In addition to land use controls and persistence of federally protected land within the Conservation Area, nonregulatory mechanisms should be employed in order to further protect and improve important agricultural and ecosystem resources.

\section{Conservation Easements}

The National Land Trust Alliance defines a conservation easement as a "legal agreement between a landowner and a land trust or government agency that permanently limits uses of the land in order to protect its conservation values. It allows landowners to continue to own and use their land, and they can also sell it or pass it on to heirs" (National Land Trust Alliance). A conservation easement is recorded on the deed of the property and protects specific resources on all or part of the property in perpetuity. They allow for flexibility in the agreement and are developed specifically to meet conservation and landowner needs. Conservation easements can be placed on private land or public land and can be donated or sold by the property owner.

Easements can be particularly useful if resources are threatened by legal land uses permitted by the local jurisdictions land use regulations. These land use developments could be harmful to resources and ultimately diminish their value and ability to provide important ecosystem functions. This can lead to adverse effects on wildlife, habitat, water quality and quantity, etc. Alternately, establishing a conservation easement could provide a landowner with 


\section{APPENDIX I Goals, Objectives, Actions and Descriptions}

potentially considerable financial compensation. The California Department of Forestry and Fire Protection (2010) states that the protection of larger tracts of land requires economically viable cattle operations to remain undeveloped. The Conservation Area has a history of ranching culture and many of the ranching families in the region find it more and more difficult to meet increasing financial obligations such as increased estate and property taxes. Conservation easements, along with sound estate planning, can provide the financial relief needed to protect ranches and keep them in the family.

\section{Fee Simple Acquisitions}

Land having exceptionally high priority conservation values can be protected by a land trust or an agency purchasing the land outright from a willing seller such as a non-profit land trust, public agency or other organizations. The use of fee simple acquisition may be appropriate when a high priority property is threatened by a sale. This is a more expensive method of conservation than a conservation easement especially when land management and conservation projects are included. If it were a conservation easement, land management would be handled by the landowner.

Another consideration of outright purchases is the long-term viability of agriculture within the Conservation Area. For example a fee simple acquisition by the land trust would inevitably take the land out of agricultural production because of limited resources and it is not in the purview of the Conservancy to do agriculture. For this reason, acquisition projects should only be taken on when agricultural uses on the property are no longer viable or when uses compatible with agriculture can be successfully accommodated. Land acquisition is also important because it allows the new owner to maximize public benefit. For example, a parcel of land was purchased for the protection of resources, but the land can now serve the public benefit by utilizing part of the property for recreation, such as hiking.

\section{Land use management}

Management is an important part of protecting targeted resources. Working landscapes can be used to meet conservation objectives, however, they require the development and implementation of management strategies and appropriate technology to reduce the conflict between the production of cattle and other agricultural products (Brunson and Huntsinger 2008). Land management is implemented in the form of Management, Measures and Practices 


\section{APPENDIX I Goals, Objectives, Actions and Descriptions}

(MMPs) also known as Best Management Practices (BMPs). MMPs are techniques, tools and treatments aimed at improving and protection ecological resources, generally watershed health.

Best Management Practices have been developed and described by regulatory agencies, restoration organizations, ranchers and others. A culmination of these practices is described in the Natural Resource Conservation Service's Field Office Technical Guides. The Best Management Practices shown below in the goals, objectives and actions correspond to those used by the NRCS in the National Handbook of Conservation Practices (NHCP) for further reference. Land management practices may require permits from local, state or federal agencies as well as the need for further technical advice/service.

There is an abundance of well-researched information on MMPs available in the National Handbook of Conservation Practices, though it is important to note that MMPs can be regionally or locally adapted to climate, topography, soil type, vegetation type, etc.

Implemented MMPs should be applicable to localized conditions of the Upper Salinas Conservation Area and the microclimates that exist in the small valleys, terraces and foothills of the surrounding mountain ranges. In the case of the Upper Salinas Watershed, MMPs will be tailored to fit the unique features and needs of the area. Technical assistance and permitting can be handled by the Upper Salinas Resource Conservation District, the NRCS or in combination with partner agencies and organizations. Additional information can be found at the NRCS website (www.nrcs.usda.gov/technical/efotg/).

\section{Restoration}

A restoration project, also known as a "repair, rehabilitation, and enhancement project", is "... an intentional activity that initiates or accelerates the recovery of an ecosystem with respect to its health, integrity and sustainability" (Society for Ecological Restoration International, http://www.ser.org/content/ecological restoration primer.asp\#3). The goal of restoration projects is to improve the condition of land that has been disturbed and/or damaged. Restoration efforts vary in intensity, which is the degree to which the landscape will be changed as a direct result of the project both during project construction and after the project has been established. They can vary from passive native plant re-vegetation to engineered in-stream improvement projects.

Restoration projects implemented on privately owned land can be done separately or in addition to land acquisition agreements. Many restoration projects, particularly restoration in stream or riparian areas, wetlands and ponds require permits as well as technical 


\section{APPENDIX I Goals, Objectives, Actions and Descriptions}

advice/service. Projects can be expensive and are often funded and implemented by nonprofits, State agencies, the Natural Resource Conservation Service, the Las Tablas-Upper Salinas Resource Conservation District or a combination of these entities. Specific restoration techniques are listed below in the goals, objectives, and actions section.

\section{Goals, Objectives, and Actions}

\section{Goal 1: Private land within the Conservation Area will be protected and restored to provide sufficient food, breeding habitat and cover for native wildlife species.}

Objective 1.1: Work with landowners to establish long-term conservation agreements including but not limited to conservation easements and land acquisitions to protect private land from the threat of development and intensification of land uses.

Action 1.1.1: The Land Conservancy shall work to partner with landowners of the large properties near already protected landscapes identified in Section 4.4 of the Upper Salinas Headwaters Conservation Plan.

Action 1.1.2: The Land Conservancy should develop a public outreach plan that includes initiating contact to develop a working relationship with interested landowners and appropriate agencies and organizations. This may include phone calls to individuals, attending local Cattlemen Association meetings, workshops, etc. Initial contact is to establish where property owners stand on the potential for conservation and to let them know the Conservancy would be interested in working with the landowner if the landowner was interested in developing a partnership. Future discussions between parties would be about establishing the partnership and understand the needs of the landowner and the Conservancy.

Action 1.1.3: The Land Conservancy shall provide outlets for unexpected land conservation opportunities. Opportunities will be evaluated through the Land Conservancy's existing conservation review process. It is possible that the Conservancy will be approached by a landowner wanting to partner with the Conservancy. These landowners may not have initially been in the scope of priorities for the Conservancy. Projects proposed by willing landowners 


\section{APPENDIX I Goals, Objectives, Actions and Descriptions}

should be evaluated through the formal staff, Land Committee, Board of Directors review process to determine if these opportunities are worth pursuing.

Action 1.1.4: The Land Conservancy shall develop a program that will recognize and award landowners and partners in the completion of successful projects. Proper recognition and credit should be given to landowners and partnering agencies and organizations. Successful agreements should be publically celebrated, highlighting the land and landowners where possible.

Action 1.1.5: The Land Conservancy shall work with conservation partners to establish agreements that are mutually beneficial for the Conservancy and the landowner. Agreements should be flexible for landowners and provide the important long-term resource and ecosystem protection. This will allow landowners to be adaptable to changing markets in order for them to continue to have viable operations, but rigid enough to protect ecosystem and landscape features from different types potential future development.

Action 1.1.6: The Land Conservancy shall work with conservation partners to develop specific conservation objectives for individual properties, establish indicators, collect baseline data and a plan of action to achieve objectives. This may include the preservation and recommended projects for enhancement of particular landscape resources. Establishing objectives and specific plans of action for each property will also provide the indicators for a monitoring protocol to ensure that conservation objectives are being met.

Objective 1.2: Protect and Restore damaged or degraded habitat areas important to wildlife on already protected private land

Action 1.2.1: The Land Conservancy shall work with willing landowners to identify areas of particular ecosystem and habitat features that have been damaged or degraded. This includes review of available maps, aerial photography and site visits with the landowner. Discussions about potential areas and potential project plans shall be negotiated during the conservation agreement talks with conservation partners. Areas shall be identified where wildlife habitat can be enhanced or restored in order to improve the quality of habitat for a targeted or multiple 


\section{APPENDIX I Goals, Objectives, Actions and Descriptions}

species. This may include the addition of in-stream habitat features for fish, hardwood stand (oak stand) establishment and preservation, riparian habitat restoration, etc. The Conservancy, landowner(s) and other potential agency or organization partners can work to streamline permits, secure funding and provide technical advice and assistance to ensure success of the project.

Action 1.2.2: The Land Conservancy and its partners shall work to secure funding to carry out restoration and land management projects.

Action 1.2.3: $(658,659,657)$ The Land Conservancy, landowners and/or other partnering entities shall work to enhance damaged or degraded wetland areas on lands with existing longterm conservation agreements. Wetlands shall be restored/enhanced in order to maintain its hydrological function and wetland vegetation characteristics as described in NRCS's National Handbook of Conservation Practices. Enhancement projects should strive to provide important habitat features for managed species as well as the variety of wildlife that utilize wetland habitat. Enhancement of wetlands may require some sophisticated land manipulation, knowledge of wetland functions and consultation with NCRS and an experienced engineer may be required. Wetland functions are attributable to their structure and contain three primary characteristics:

- A supply of water at or near the surface for at least a portion of the growing season

- Hydric soils, which develop under saturated conditions. These soils have the capacity to hold water at or near the surface.

- Wetland vegetation includes plants adapted to growing in wet soils.

Restoration of wetlands involved restoring or enhancing one or more of these three characteristics. Hydric soils form over a long period of time and are difficult to create. Generally, restoration of wetlands occurs where hydric soils already exist, but the vegetation and/or hydrology has changed. Water retention is a common wetland restoration project that involved establishing or reestablishing water holding capacity on areas that have been drained. The effort and need to restore wetland habitat will depend on site specific factors, such as type of damage and degree to which the damage has been done and the type of land uses occurring at or near the site. Site analysis and restoration planning is an important tool for successful wetland restoration. Local NRCS Office and the Local Resource Conservation District office can provide information and make recommendations on wetland restoration assessments. 


\section{APPENDIX I Goals, Objectives, Actions and Descriptions}

Re-vegetation projects may include mulching and reseeding, planting willow poles, and shrubs. Re-vegetation for cattle ranches will require an exclusionary or intensely managed wetland riparian grazing system to control plant growth and noxious weeds. Chemical and mechanical treatments of noxious weeds in and around wetland areas should be handled with extreme caution and be part of a planned wetland restoration and management system.

Action 1.2.4: (644) Landowners, land managers and other essential entities should work to manage wetland areas for native wildlife species. Wildlife species management goals and objectives should be identified. Types, amount and distribution of necessary habitat elements and management actions should be developed for desired species

Native plants should be used whenever possible. Management should include plant material specification from the California Vegetation Guide specific to the Major Land Resource Area (MLRA) for the specific wetland site. Invasive plant species and federally/state listed noxious and nuisance species shall be controlled using cultural, mechanical, chemical and/or biological measures appropriate to control invasive species with minimal impacts wetland features. Management or otherwise activities shall be planned outside of the primary nesting season (April 1- July 15) to minimize impacts to resident nesting birds and breeding amphibians. If management is necessary during this time, consult an NRCS biologist to formulate alternative treatments. Planning specification should include the timing, frequency, duration and intensity of the type of management needed to meet the objectives (NRCS 2011).

Action 1.2.5: (396) Landowners, managers and/or hired consultants should work to modify or remove man-made structures that impede migration of steelhead and other aquatic organisms. Removal of barriers such as log jams, man-made dams and other impediments allow for increased utilization of in-stream habitat by aquatic species and allow migrating species such as steelhead reach historic breeding habitat further up stream. This is particularly important to tributaries below Santa Margarita Reservoir, which has small steelhead migrations.

Action 1.2.6: (645) Landowners and land managers should work to develop and implement a habitat management plan for upland wildlife species. The Land Conservancy and Landowner may negotiate conservation agreement terms that establishes particular responsibilities and obligations to complete habitat management plans. Grassland, hardwood, shrub/scrub communities exist within the Conservation Area. Many wildlife species depend on upland 


\section{APPENDIX I Goals, Objectives, Actions and Descriptions}

habitat for their survival. Establishing vegetation for cover, food, and provide for migration and territory movement should be managed for. Structures should be installed to help provide necessary shelter, food, and movement of wildlife.

Vegetation can also be manipulated to ensure optimal habitat conditions over a long period of time. Perennial vegetation such as grasses, shrubs and trees can help provide food and cover requirements while simultaneously reducing soil erosion, filtering runoff and increasing infiltration. Different successional stages can be sustained depending on management objectives. For example brush and tree clearing can open up the ground floor and invite early succession and pioneer species such as shrub and grassland species can be planted or allowed to naturally re-vegetate the disturbed area. Re-vegetated early succession stage communities provide habitat for many avian species, reptiles, amphibians and mammals. Species have specific habitat requirements and management actions should reflect wildlife management objectives. However, upland habitat management should be comprehensive and manage the biodiversity found in the region.

Treatment of noxious weeds is essential to managing and creating upland wildlife habitat. Long-term use of fire, chemicals, manual removal, prescribed grazing, or a combination of techniques maybe necessary and should be included as part of the management plan.

Regular vegetation management, burning, mechanical removal and mowing, and growing during periods that do not affect breeding, nesting and rearing periods of wildlife species can help to maintain desired habitat requirements for targeted wildlife, create edge between forested areas and early succession habitat, manage brush in way that provides habitat and also reduces fire risk and increases forage production.

Upland habitat management should be monitored and actions should be adaptive to management successes and shortfalls. Baseline conditions should be established and continued monitoring should assess wildlife, vegetation and changes in invasive species.

\section{Objective 1.3: Protect the habitat values found in each vegetation community}

Action 1.3.1: (528a) Landowners and/or land managers should employ a prescribed grazing system based on pre-determined management objectives. Sustainable cattle operations rely on timing, intensity and frequency in order to provide sustainable ecosystem functions and viable grassland productivity (Bellows 2003). Research has shown that properly managed livestock 


\section{APPENDIX I Goals, Objectives, Actions and Descriptions}

and grazing can increase productivity, decrease expenses and protect ecosystem features (Bellows 2003; Macon 2002; Herrick et al. 2002; Paine et al. 1999; Berton 1998). Two of the dominant grazing systems are continuous grazing and rotational grazing. Continuous grazing is the more traditional, least time and cost intensive grazing management system. Rotational grazing has several grazing systems associated with it, but it basically moves cattle to different pastures to allow particular pastures a degree of rest in order to regenerate quality forage vegetation. High intensity, short duration grazing with extending resting periods for pastures are designed for grassland areas, provide the most management flexibility and under proper management produce the most sustainable results. A combination of rotational grazing systems can be employed depending on microclimatic conditions, vegetation and forage availability, and management objectives i.e extensive and intensive. Rotational grazing systems create sustainable and continued vegetation/habitat generation for wildlife species and depending on management goals, different species of wildlife can be managed.

Intensive grazing is an appropriate approach on annual and perennial grassland areas. Extensive is more appropriate for shrub/scrub habitat where forage species are different, sparse and slower growing. Traditional rotational grazing utilizes larger, less managed pastures to be grazed. Intensive grazing systems, although more time intensive, manages for forage consumption, quality and vegetation regeneration. Pastures are divided into paddocks. Paddocks are analyzed to determine appropriate forage quality to meet the expected needs of livestock and closely monitor the recovery of resting paddocks. Quality and growth of vegetation are the basis for this type of managed grazing. If plants are maturing faster than a pasture can be grazed, mature pastures can be harvested for hay to supplement grazing control on other pastures and harvested pastures can be grazed after plant regeneration. On pastures with slower growing vegetation, pastures can be rested based on quality and growth rates. Other grazing systems include strip grazing, which is utilized to prevent founder and bloat in pastures containing a high proportion of legumes. This method forces animals to eat both leaves and stems. Temporary fencing can be used to ration forage supplies based on herd and pasture forage needs. Leader-follower systems where herds can be a mixture of the same species or of different species are sent first of last into a pasture depending the herds nutritional needs. The first group of animals have the highest nutritional needs and have access to the best forage. The second group of animals who have lower nutritional needs graze the lower quality forage in the pasture. Multiple-livestock grazing systems utilize different species of 


\section{APPENDIX I Goals, Objectives, Actions and Descriptions}

livestock to target different forage types such as invasive species and serve different management goals (Clark Conservation District).

Consider selecting for cattle that have behavior associated with management goals. Cattle can also be trained to particular types of vegetation selection. Cattle and other livestock can be encouraged, and to some degree, trained to select specific forage areas and species (Bellows 2003).

Regular monitoring is required for intensive grazing systems, but it allows for greater management flexibility including when and how much supplemental hay and other livestock feed is necessary, reducing herd numbers, or when to wean young livestock (weaning animals early reduces demand on a reduced forage supply and helps to reduce stress on pasture regeneration.), how much fencing is needed. It is recommended that ranch managers consult extension services, NRCS, the RCD or a private consultant to develop specific goals and action items for grazing systems. Generally speaking, ranch managers should start with a smallexperimental grazing system to gain experience making observations and practices making the necessary land management decisions.

Action 1.3.2: (472) Landowners should employ livestock exclusion techniques in order to protect riparian areas and any other critical area such as areas being restored, critical habitat, and areas with sensitive hydrological functions. Exclusion is a simple and effective management tool that protects vegetation which serves as food and cover for wildlife, sedimentation trapping, water quality, erosion control, etc. Fencing is the primary and most common tool used to accomplish this and can be supplemented by using attractants. Livestock exclusion helps to protect seedlings from effects of livestock such as browse, rubbing, and soil compaction essentially allowing areas rest that are reestablishing. Depending on management goals, a combination of livestock exclusion and short-term-high intensity grazing practices can be employed in riparian areas to reduce fire regimes, maintain increased vegetation species composition for wildlife, and promotes healthy nutrient and mineral cycling. Figure I.1.1 shows an example of how cattle can be controlled in and around riparian areas. 


\section{APPENDIX I Goals, Objectives, Actions and Descriptions}

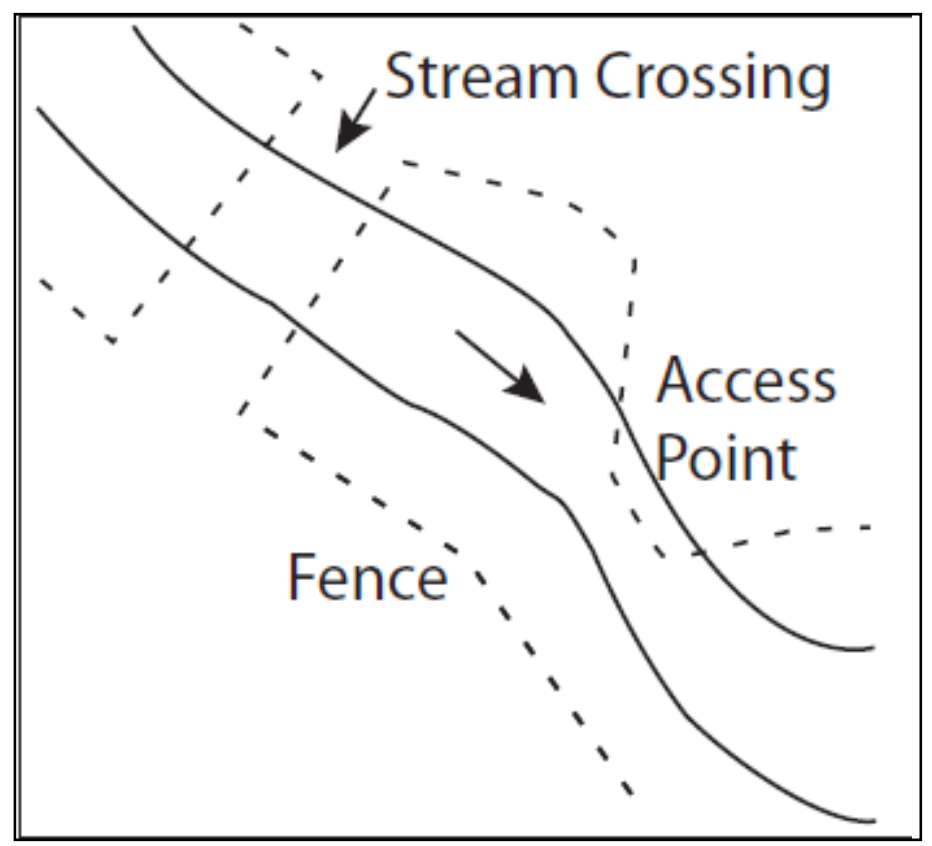

Figure I.1.1 Fencing along riparian areas with access points and stream crossing along stable stream and stream channel areas.

Source: Goard 2006

Exclusionary fencing is particularly important during vegetation establishment of a riparian area. The most upfront economical option is a single- or double strand high-tensile electric fence although electric fence maintenance can be time intensive. Electric fencing can also be mobile if management includes periodic riparian grazing (Goard 2006 and Bellows 2003).

Barbed wire or double-strand smooth wire is another option and is more permanent than the electric fence option. High-tensile nonelectric fences require more wire than barbed wire fencing, but may be a more appropriate permanent fencing material. This type of fencing is also considered friendlier to livestock and wildlife. Woven wire fences are not a good option for riparian fencing because the wire can trap debris and is more prone to flood damage (Goard 2006).

Fencing should be placed at the maximum distance from the stream as possible (with a desired minimum of 66 feet from the high water mark on both sides of the stream). The benefits of riparian corridors greatly increase as fencing is placed further away from the stream. Fences placed too close to streams can be damaged during peak flow and the benefit of riparian corridors is reduced. Fencing is also an important tool used to subdivide grazing land into 


\section{APPENDIX I Goals, Objectives, Actions and Descriptions}

smaller units for management purposes. As a result, upland and riparian areas can be more intensively managed (Goard 2006).

Action 1.3.3: Cattle operators and operation owners should Implement off-site attractants to lure cattle away from specific areas, particularly riparian areas. Attractants can be used to compliment the use of exclusion fencing. This method protects important riparian wildlife habitat, distributes the herd to attain forage utilization goals and prevents/reduces erosion in sensitive areas. Methods for attracting livestock away from riparian areas include (Leonard et al. 1997):

- Provide alternative watering systems.

- Plant palatable forage species on adjacent upland areas.

- Graze riparian areas when upland vegetation is abundant and riparian vegetation is in peak growth.

- Do not graze riparian areas when they are wet or scorched by drought.

- Use prescribed burning on upland areas to enhance forage production and palatability.

- Place feed supplements such as salt, grain, hay, or molasses in upland areas of paddocks away from the riparian areas.

- Place brush or boulders along stream banks to discourage livestock from grazing and congregating in riparian areas.

Action 1.3.4: (612) Landowners, land managers, and/or any relevant partnering agencies or organizations should establish native trees, grasses and shrubs by planting seeds or woody cuttings to improve wildlife habitat, reduce erosion, improve water quality, and improve biological diversity in appropriate areas. Oaks and other hardwood provide a source of food, nesting sites and cover for several species of wildlife in oak savannah communities, and provide shade to cattle. A diversity of native upper canopy, sub canopy and ground layer vegetation provide essential habitat functions to native wildlife species. Trees in riparian areas also act as a thermo regulator controlling in stream temperatures which affect dissolved oxygen levels. Macro invertebrates and fish species depend on a narrow range of available oxygen in the water which is partially controlled by temperature regulated by shade trees.

Action 1.3.5: (314) Landowners and land managers should utilize brush management through the use of prescribed fire or selective manual removal will keep some desirable brush for 


\section{APPENDIX I Goals, Objectives, Actions and Descriptions}

habitat, reduce fuel loading, increase vegetation composition and therefore increase biodiversity on the landscape. Brush management serves several purposes in addition to creating wildlife habitat including (Whisenant 1997):

- Restore natural plant community balance.

- Create the desired plant community.

- Restore desired vegetative cover to protect soils, control erosion, reduce sediment, improve water quality and enhance stream flow.

- Improve forage accessibility, quality and quantity for livestock.

- Protect life and property from wildfire hazards.

Brush management planning should be utilized to achieve desired goals keeping in mind that the accumulation of brush in some instances may provide valuable habitat features. Removal or reduction of excessive wood plants is an important management tool for providing grassland habitat on rangeland properties. Using mechanical, chemical, biological, prescribed burning and grazing or a combination of these methods, brush management goals can be achieved. The type of brush management largely depends on management goals such as specific species habitat requirements, forage production, etc. Brush management and methods used are influenced by several factors (Whisenant 1997):

- Practical considerations

- Regulatory restrictions

- Degree of selectivity needed

The density, age and size of brush

- Resprouting ability of native vegetation

- Potential for creating new problems

- Maintenance requirements.

Action 1.3.6: Landowners and land managers should implement a noxious weed management plan using fire, grazing and manual removal to control the proliferation of noxious weeds and to promote the growth of native vegetation species composition, which provides sufficient food and cover for a variety of wildlife species. The Land Conservancy may partner with landowners on noxious weed control projects pending an evaluation of services, resources required, and if the project itself will have overall benefits in line with the mission and objectives of the Land Conservancy. Noxious weed management is essential to attaining desired management goals and is one of the biggest problems that rangeland managers and owners face in the United 


\section{APPENDIX I Goals, Objectives, Actions and Descriptions}

States (Brooks and Lusk 2008). Understanding of individual plant ecology is essential for determining the proper method. Preventative measures are essential to curtailing invasive species. Once noxious weeds become established and proliferate, it becomes increasingly difficult and expensive to address the issue. The following are descriptions of common tools utilized in controlling invasive species:

- Prescriptive fire (334) - Prescribed burns are intentional and controlled burn events with targeted outcomes. Fire can be a tool to control some invasive plant species.

Ultimately, an understanding of plan ecology and life history and any associated species can help to identify ways to integrate control measures, including fire. It is an ecosystem disturbance whose influence on the environment is based on the frequency, intensity, interactions with other disturbances and seasonal occurrence (Masters and Shelley 2001). Single prescribed burn episodes are often ineffective to eradicate invasive species. Operators and land managers should develop a multiple year prescribed burn plan that targets invasive species and establishes contingency plans and monitoring protocols to assess effectiveness. Prescribed burns have the potential to enhance proliferating invasive species. Effective prescribed burning integrates other control measures (chemical, cultural, and biological) based on plant ecology.

- Prescriptive grazing - Prescriptive grazing is an often overlooked and underutilized grazing tool. In combination with other noxious weed control treatments, it can control weeds and help restore native and desirable vegetation. However, indiscriminant grazing can foster noxious weed growth. Understanding plant ecology of individual species can help determine whether their seeds will survive being digested and deposited in concentrated nutrients found in the dung, which increased the probability of germination. Careful grazing management can help reduce noxious weeds and promote native ecology.

Prescription grazing should be done to balance palatability for livestock and susceptibility for weed defoliation. An example of this is cheatgrass, which is highly palatable and can be effectively reduced with high intensity spring grazing. Time of year and intensity of defoliation strongly dictate the ability of plants to grow post grazing. Due to nutrient and water availability for plant regeneration, many plant species are tolerant of grazing in the early growing season. As nutrients become less abundant later in the year, plants invest more energy and resources into seed production. Targeted grazing later in the season can be advantageous to weed control. Caution should be given to 


\section{APPENDIX I Goals, Objectives, Actions and Descriptions}

grazing when seeds are set and plants are flowering due to the increased probability of livestock spreading seeds. Livestock seed dispersal can be minimized by avoiding areas during this time and/or putting livestock in holding pens for short periods of time to allow digestion to prevent livestock from spreading seeds to uninfested areas (Frost and Launghbaugh 2003).

The main factors that determine stocking rates for weed control programs include palatability of the plant and the density of the weed infestation. Smaller infestations of highly palatable plants can best be controlled with smaller stocking rates. Spotted knapweed for example, can be effectively controlled using smaller stocking rates of sheep due to the plant being a preferential and palatable species for sheep. Dense infestations or less palatable species can be controlled by higher intensity stocking rates. This forces herds to more evenly utilize forage in the pasture. Herding and fencing livestock into particular areas within a pasture can help decrease targeted noxious weed areas. (Frost and Launghbaugh 2003).

Another method of using livestock that can supplement prescribed grazing is to utilize multiple species grazing techniques. Cattle are adapted to eating grass and roughage and have the ability to ferment fibrous vegetative material. Cattle are therefore considered better adapted to eating herbaceous vegetation such as dormant grasses. Goats are adapted to stripping leafy debris from woody material and are also able to chew woody branches. They are therefore a better option for browsing invasive woody species such as young juniper trees. Sheep can access topography that is otherwise difficult to access using manual or chemical weed controls. Sheep are also very social and therefore provide a degree of management flexibility. Sheep have been used successfully to control a variety of noxious herbaceous vegetation (Frost, R.A. and Launghbaugh 2003; Lacey et al. 1992).

Selecting the species is only a step on using multiple species as a noxious weed control program. Different breeds have different nutritional requirements and can even differ among individuals based on their preference, age (changing dietary requirements), body condition, past experience with food, sex, and physiological state. Livestock can be encouraged to select for specific plants, but will not routinely eat them if it does not meet their nutritional requirements (Frost and Launghbaugh 2003).

- Mechanical Removal and Reseeding - Seeding desirable plants is thought to be the most effective long-term approach for areas with little or no non-existing desirable plant 


\section{APPENDIX I Goals, Objectives, Actions and Descriptions}

vegetation (Masters and Shelley 2001). Establishing native grasses, forbs, legumes and shrubs promotes competition against proliferating invasive species and increase resistance to noxious weed takeovers (Masters and Shelley 2001).

There are a number of mechanical treatments available used to control noxious weeds. Mechanical treatments remove the reproductive crowns or enough of the root to kill the weed (Masters and Shelley 2001). Mowing and tilling are common mechanical treatments and their effectiveness is dependent upon targeted plant physiology and timing of the treatment. Mowing can control annuals and some biennials and perennials if the treatment is applied before the formation of viable seeds (Masters and Shelley 2001). Multiple treatments must be applied over several years to effectively treat the life cycle and different generations of plants (Masters and Shelley 2001). Mechanical treatments can also have a negative impact on some perennial or woody plant species that can reproduce vegetatively. Cutting older growth and stimulate newer growth on these species. Perennial species that have this growth characteristic can be damaged or destroyed by using tilling practices i.e. bulldozing, root-plowing or grubbing (Derscheid et al. 1985 and Vallentine 1989). Generally, mechanical treatments are limited on rangelands due to intensive labor requirements and high associated costs (Masters and Shelley 2001).

- $\quad$ Herbicidal treatment - Herbicides have been a long standing treatment for weed control on rangeland in North America (Bovey 1995). Their potential to contaminate the ground and/or water, cost of repeat application, and affects on desirable plant species have resulted in concerns of their usage (Masters and Shelley 2001). There are a number of different herbicides and they are categorized by their chemical make-up and their mode in which they affect the system, tissue, or process (Devine et al. 1993, Ross and Lembi 1999). See Table I.1.1 for a selected list of approved herbicides for non-cropland. Herbicides are selected based on rates of application, environmental conditions and the method of application. The most commonly used herbicides utilized on rangeland landscapes are auxinlike growth regulators. These herbicides control broadleaf plants and do not affect grasses when applied using recommended application rates (Masters and Shelley 2001). 


\section{APPENDIX I Goals, Objectives, Actions and Descriptions}

\begin{tabular}{|c|c|c|c|c|c|c|}
\hline Chemical group & Common name & Chemical name & Mode of action & $\begin{array}{l}\text { Plants } \\
\text { controlled }\end{array}$ & Activity $^{3}$ & $\begin{array}{l}\text { Application } \\
\text { timing }^{4}\end{array}$ \\
\hline Benzoic acid & Dicamba & 3,6-dichloro-2-methoxybenzoic acid & $\begin{array}{l}\text { Auxin-type growth } \\
\text { regulator }\end{array}$ & B & $\mathrm{F}, \mathrm{S}$ & PRE, POST \\
\hline Benzonitrile & Bromoxynil & 3,5-dibromo-4-hydroxybenzonitrile & Photosynthetic inhibitor & B & $\mathrm{F}$ & POST \\
\hline Bipyridilium & Paraquat & 1,1'-dimethyl-4,4'-bipyridinium ion & $\begin{array}{l}\text { Photosystem } 1 \text { energized } \\
\text { cell membrane disrupter }\end{array}$ & $\mathrm{B}, \mathrm{G}$ & $\mathrm{F}$ & POST \\
\hline Semicarbazones & Diflufenzopyr & $\begin{array}{l}\text { 2-[1-[[[(3,5-difluorophenyl)amino }] \\
\text { carbonyl]hy-drazono]ethyl]-3-pyridine- } \\
\text { carboxylic acid }\end{array}$ & Auxin transport inhibitor & B & $\mathrm{F}$ & POST \\
\hline \multirow[t]{3}{*}{ Imidazolinone } & Imazethapyr & $\begin{array}{l}\text { 2-[4,5-dihydro-4-methyl-4- } \\
\text { (1-methylethyl)-5-oxo-1H-imidazol-2-yl]- } \\
\text { 5-ethyl-3-pyridinecarboxylic acid }\end{array}$ & $\begin{array}{l}\text { Branched-chain amino } \\
\text { acid inhibitor }\end{array}$ & $B, G$ & $\mathrm{~F}, \mathrm{~S}$ & PRE, POST \\
\hline & Imazapyr & $\begin{array}{l}\text { 2-[4,5-dihydro-4-methyl-4- } \\
\text { (1-methylethyl)-5-oxo-1H-imidazol-2-yl]- } \\
\text { 3-pyridinecarboxylic acid }\end{array}$ & $\begin{array}{l}\text { Branched-chain aminor } \\
\text { acid inhibitor }\end{array}$ & $\mathrm{B}, \mathrm{G}$ & $\mathrm{F}, \mathrm{S}$ & PRE, POST \\
\hline & Imazapic & $\begin{array}{l}\text { 2-[4,5-dihydro-4-methyl-4-(1-methylethyl)- } \\
\text { 5-oxo-1H-imidazol-2-yl]-5-methyl-3- } \\
\text { pyridinecarboxylic acid }\end{array}$ & $\begin{array}{l}\text { Branched-chain amino } \\
\text { acid inhibitor }\end{array}$ & $\mathrm{B}, \mathrm{G}$ & $\mathrm{F}, \mathrm{S}$ & PRE, POST \\
\hline \multirow[t]{3}{*}{ Phenoxy acid } & $2,4-\mathrm{D}$ & (2,4-dichlorophenoxy)acetic acid & Auxin-type growth regulator & B & $\mathrm{F}$ & POST \\
\hline & 2,4-DB & 4-(2,4-dichlorophenoxy)butanoic acid & Auxin-type growth regulator & B & $\mathrm{F}$ & POST \\
\hline & MCPA & (4-chloro-2-methylphenoxy)acetic acid & Auxin-type growth regulator & B & $\mathrm{F}$ & POST \\
\hline Phenylurea & $\begin{array}{l}\text { Diuron } \\
\text { Tebuthiuron }\end{array}$ & $\begin{array}{l}\text { N'-(3,4-dichlorophenyl)-N,N-dimethylurea } \\
\text { N-[5-(1,1-dimethylethyl)-1,3,4-thiadiazol- } \\
\text { 2-yl]-N,N'-dimethylurea }\end{array}$ & $\begin{array}{l}\text { Photosynthetic inhibitor } \\
\text { Photosynthetic inhibitor }\end{array}$ & $\begin{array}{l}B, G \\
B, G\end{array}$ & $\begin{array}{l}F, S \\
F, S\end{array}$ & $\begin{array}{l}\text { PRE, POST } \\
\text { PRE, POST }\end{array}$ \\
\hline \multirow[t]{2}{*}{ Picolinic acid } & $\begin{array}{l}\text { Clopyralid } \\
\text { Picloram }\end{array}$ & $\begin{array}{l}\text { 3,6-dichloro-2-pyridinecarboxylic acid } \\
\text { 4-amino-3,5,6-trichloro-2-pyridine- } \\
\text { carboxylic acid }\end{array}$ & $\begin{array}{l}\text { Auxin-type growth regulator } \\
\text { Auxin-type growth regulator }\end{array}$ & $\begin{array}{l}\mathrm{B} \\
\mathrm{B}\end{array}$ & $\begin{array}{l}\text { F, S } \\
F, S\end{array}$ & $\begin{array}{l}\text { PRE, POST } \\
\text { PRE, POST }\end{array}$ \\
\hline & Triclopyr & [(3,5,6-trichloro-2-pyridinyl)oxy]acetic acid & Auxin-type growth regulator & B & $\mathrm{F}, \mathrm{S}$ & PRE, POST \\
\hline \multirow[t]{3}{*}{$s$-Triazine } & Atrazine & $\begin{array}{l}\text { 6-chloro-N-ethyl-N'-(1-methylethyl)-1,3,5- } \\
\text { triazine-2,4-diamine }\end{array}$ & Photosynthetic inhibitor & $\mathrm{B}, \mathrm{G}$ & $\mathrm{F}, \mathrm{S}$ & PRE, POST \\
\hline & Hexazinone & $\begin{array}{l}\text { 3-cyclohexyl-6-(dimethylamino)-1-methyl- } \\
\text { 1,3,5-triazine-2,4(1H,3H)-dione }\end{array}$ & Photosynthetic inhibitor & $B, G$ & $\mathrm{~F}, \mathrm{~S}$ & PRE, POST \\
\hline & Simazine & $\begin{array}{l}\text { 6-chloro-N,N'-diethyl-1,3,5-triazine- } \\
\text { 2,4-diamine }\end{array}$ & Photosynthetic inhibitor & $B, G$ & $\mathrm{~F}, \mathrm{~S}$ & PRE, POST \\
\hline \multirow[t]{3}{*}{ Sulfonyl urea } & Chlorsulfuron & $\begin{array}{l}\text { 2-chloro-N-[[(4-methoxy-6-methyl-1,3,5- } \\
\text { triazin- 2-yl)amino]carbonyl] } \\
\text { benzenesulfonamide }\end{array}$ & $\begin{array}{l}\text { Branched-chain amino } \\
\text { acid inhibitor }\end{array}$ & $B, G$ & $\mathrm{~F}, \mathrm{~S}$ & PRE, POST \\
\hline & Metsulfuron & $\begin{array}{l}2-[[[[(4-\text {-methoxy-6-methyl-1,3,5-triazin- } \\
\text { 2-yl) amino] carbonyl]amino] sulfonyl }] \\
\text { benzoic acid }\end{array}$ & $\begin{array}{l}\text { Branched-chain amino } \\
\text { acid inhibitor }\end{array}$ & $B, G$ & $\mathrm{~F}, \mathrm{~S}$ & PRE, POST \\
\hline & Sulfometuron & $\begin{array}{l}2-[[[[(4,6 \text {-dimethyl-2-pyrimidinyl)amino }] \\
\text { car-bonyl] amino]sulfonyl]benzoic acid }\end{array}$ & $\begin{array}{l}\text { Branched-chain amino } \\
\text { acid inhibitor }\end{array}$ & $\mathrm{B}, \mathrm{G}$ & $\mathrm{F}, \mathrm{S}$ & PRE, POST \\
\hline Uracil & Bromacil & $\begin{array}{l}\text { 5-bromo-6-methyl-3-(1-methylpropyl)- } \\
\text { 2,4(1H, 3H)pyrimidinedione }\end{array}$ & Photosynthetic inhibitor & $\mathrm{B}, \mathrm{G}$ & $\mathrm{F}, \mathrm{S}$ & PRE, POST \\
\hline \multirow[t]{3}{*}{ Unassigned } & Fosamine & ethyl hydrogen (aminocarbonyl)phosphonate & Unknown & B & $\mathrm{F}$ & POST \\
\hline & Glyphosate & $\mathrm{N}$-(phosphonomethyl)glycine & $\begin{array}{l}\text { Aromatic amino } \\
\text { acid inhibitor }\end{array}$ & $\mathrm{B}, \mathrm{G}$ & $\mathrm{F}, \mathrm{S}$ & POST \\
\hline & Quinclorac & 3,7-dichloro-8-quinolinecarboxylic acid & Cell wall formation inhibitor & r $B, G$ & $\mathrm{~F}, \mathrm{~S}$ & PRE, POST \\
\hline \multicolumn{7}{|c|}{$\begin{array}{l}{ }^{2} \text { Chemical group and mode of action from Ross and Lembi (1999) and common } \\
{ }^{2} \mathrm{~B}=\text { broadleaf species and } \mathrm{G}=\text { grass species } \\
3{ }^{3} \mathrm{~F}=\text { taken up by plant foliage and } \mathrm{S}=\text { has activity in the soil } \\
{ }^{4} \mathrm{PRE}=\text { applied before plant emerges and POST = applied after plant emerges }\end{array}$} \\
\hline \multicolumn{7}{|c|}{ Source: Masters and Shelley 2001} \\
\hline
\end{tabular}

Table I.1.1 Selected herbicides that are currently registered for use on rangeland, pasture land and non-cropland 


\section{APPENDIX I Goals, Objectives, Actions and Descriptions}

Another commonly used herbicide is glyphosphate. This herbicide controls grasses and broadleaf weeds. Selectivity is determined by plant growth and application is ideal during the targeted plants optimal growing season and is relatively ineffective when the plant is dormant (Masters and Shelley 2001).

Ultimately, a noxious weed management program should be comprehensive, meeting management goals in an ecologically friendly and fiscally feasible way. Many of the techniques mentioned above can be used in tandem. See Table I.1.2 for examples of integrated weed control treatments. For example, herbicidal treatments can be supplemented with grazing treatments post applications. A comprehensive and holistic management approach shouldn't just target noxious weed species, but aim for vegetation community change to increase forage production, control invasive species, prevent erosion, act as a pollutant buffer, increase organic matter, increase soil moisture capacity, etc. Application of these herbicides depends on their mode of action, cost and consideration by the land manager to minimize the potential for contamination.

\begin{tabular}{|c|c|c|}
\hline Invasive Plant & Strategy components & Citation \\
\hline Acroptilon repens (L.) DC & Tillage, herbicide, and revegetation & $\begin{array}{l}\text { Dershied et al. 1963, Bottoms and Whitson 1998, } \\
\text { Benz et al. } 1999\end{array}$ \\
\hline Bromus tectorum $L$. & Tillage, herbicide, and revegetation & $\begin{array}{l}\text { Eckert and Evans 1967, Evans et al. } 1967 \\
\text { Whitson and Koch } 1998\end{array}$ \\
\hline Centaurea spp. & $\begin{array}{l}\text { Herbicide and grazing } \\
\text { Herbicide, revegetation, and biocontrol } \\
\text { Herbicide and revegetation } \\
\text { Burning and herbicide }\end{array}$ & $\begin{array}{l}\text { Whitson and Koch } 1998 \\
\text { Enloe and DiTomaso } 1999 \\
\text { Sheley et al. } 2001 \\
\text { Lacey et al. } 1995\end{array}$ \\
\hline Cirsium arvense (L.) Scop. & Herbicide and revegetation & Wilson and Kachman 1999 \\
\hline Euphorbia esula $L$. & $\begin{array}{l}\text { Herbicide and biocontrol } \\
\text { Tillage, herbicide, and revegetation } \\
\text { Tillage, herbicide, and fertilization } \\
\text { Grazing and herbicide } \\
\text { Herbicide, burning, and revegetation }\end{array}$ & $\begin{array}{l}\text { Nelson et al. } 1998 \\
\text { Selleck et al. 1962, Ferrell et al. } 1998 \\
\text { Lym and Tober } 1997 \\
\text { Lym and Messersmith } 1993 \\
\text { Lym et al. } 1997 \\
\text { Masters and Nissen 1998, Masters et al. } 2001\end{array}$ \\
\hline Hypericum perforatum $L$. & Tillage and revegetation & Gates and Robocker 1960 \\
\hline Lepidium latifolium $L$. & Mowing and herbicide & Renz and DiTomasa 1999 \\
\hline Linaria dalmatica (L.) Mill. & Tillage and revegetation & Gates and Robocker 1960 \\
\hline Opuntia stricta (Haworth) Haworth & Herbicide and biocontrol & Hoffman et al. 1998 \\
\hline Taeniatherum caput-medusae (L.) Nevski & $\begin{array}{l}\text { Burning, herbicide, and revegetation } \\
\text { Tillage, herbicide, and revegetation }\end{array}$ & $\begin{array}{l}\text { Horton } 1991 \\
\text { Young et al. } 1969\end{array}$ \\
\hline
\end{tabular}

Source: Masters and Shelley 2001

Table I.1.2 Examples of integrated weed control strategies

Action 1.3.7: Landowners should individually or with partnering consultants, agencies and organizations, develop, design and implement management guidelines that consider amphibian migration and breeding as well as bird nesting seasons can help to increase species 


\section{APPENDIX I Goals, Objectives, Actions and Descriptions}

survivorship and productivity. Developing a grazing management system and managed access road usage that considers amphibian and avian species to provide breeding, cover, food and nesting habitat are essential to species survival. Grassland bird species have specific height and percent cover requirements to ensure survival. Foraging and trampling their habit prohibits their survival and reproductive success. Intensive rotational grazing can provide pastures with habitat characteristics of managed species in resting and grazed areas. Livestock grazing can be harmful and beneficial to avian and amphibian habitat. California red-legged frog and the California tiger salamander can be negatively affected by trampled aquatic vegetation and increased bank erosion, which creates unsuitable habitat. Beneficial grazing to these species is the result of the creation of stock ponds that can simultaneously be used as habitat and limited grazing can maintain suitable habitat by controlling weedy species and bulrush growth in and around stock ponds (USFWS 2002).

California tiger salamanders and California red-legged frog have similar breeding habitat requirements that are found within the Conservation Area. Both rely on standing water for breeding and larval development. The hydroperiod, or length of time ephemeral surface water is available and timing of its availability will dictate breeding success rates (Anderson 1968, Feaver 1971). Tiger salamanders require ten weeks to complete their metamorphic cycle, whereas the red-legged frog requires approximately 3.5 to one year to reach its sub-adult stage. Limited grazing can help reduce evapotranspiration through vegetation, while maintaining the appropriate riparian vegetation and emergent vegetation for cover and as a rearing food source. Both the California red-legged frog and the California tiger salamander utilize stock ponds or artificially constructed vernal pools that stay wet into late spring.

For tiger salamanders, breeding generally occurs between late November and Late April (Jennings and Hayes 1994). Tiger salamander species will migrate up to 3 miles to a pond, vernal pool, or wetland to breed. Migration occurs during that time where males arrive two to four weeks before females (Loredo 1996). California tiger salamanders are secondary burrowers, utilizing the burrows of other species such as ground squirrels and mice in the summer and fall when it is dry (Jennings and Hayes 1994 and USFWS 2004b).

California red-legged frogs can thrive in areas with managed grazing activities. Stock ponds provide common breeding habitat (USFWS 2002). Managed grazing can provide and even improve adequate migrating corridor vegetation, native riparian vegetation to provide cover and some emergent vegetation for food and cover for tadpoles. Unmanaged grazing can result in severe habitat disturbances which can change water temperature, increase sedimentation 


\section{APPENDIX I Goals, Objectives, Actions and Descriptions}

and affect sources of food and cover for the frogs (Duff 1979 in USFWS 2002; Gunderson 1968 in USFWS 2002).

Caution should be given to migrating amphibians on access roads, particularly at night and during the wet weather when breeding adults are active (USFWS 2002, Bulger et al. 2003, Fellers and Kleeman 2007). This includes driving slow near areas with standing water and posting signs to tell people to take precautions. Overland movement during dry periods does occur in response to receding water sources (USFWS 2002). California red-legged frogs remain near aquatic habitat and within riparian habitat, but will travel out of these areas to reach standing water to breed (USFWS 2002, Fellers and Kleeman 2007, Bulger et al. 2003).

Managed cattle grazing should provide sufficient grazing to keep invasive species out and provide easy access to standing water for frogs and allow rest to riparian breeding and avian ground nesting habitat particularly in shrub and grassland areas. Birds in shrub/chaparral habitat can nest anywhere from ground level to three feet off the ground. High intensity grazing systems during breeding season may affect sub canopy nesting birds. Prescribed grazing strategies should consider avian breeding cycles which, depending on the species, can last from early spring to midsummer.

Action 1.3.8: (516) Where feasible, landowners and/or managers should construct a water conveyance system that minimizes energy use (i.e. gravity-fed) and provides water sources to areas away from riparian areas and other ecologically sensitive areas to keep cattle away. Water should be conveyed for livestock or recreation using installed pipeline. Pipelines may decrease sediment, nutrient, organic, and bacteria pollution from livestock by providing an alternative to natural bodies of water such as lakes and streams. Piping helps create alternative water sources away from important conservation areas such as riparian areas and stream channels. Piping systems can provide an off stream water attractant to lure cattle away from these areas and provide additional habitat features providing water and a potential food source for wildlife. Near ground/ground level troughs, where feasible, will provide wildlife access to water sources. For above ground troughs, ramp design (in and out of the trough) will allow birds, reptiles and amphibians access to trough water sources. Piping material commonly used to transfer water depends on water transfer needs such as pumping pressure and availability. Common materials used for water piping on rangeland include:

- Plastic PE/PVC Less than 250 PSI

- Plastic PE/PVC Greater than 250 PSI 


\section{APPENDIX I Goals, Objectives, Actions and Descriptions}

- Steel

Maintenance, such as fixing and replacing piping, may be necessary to fix water leaks. This ensures maximum utilization of water, although some landowners have utilized leaks in pipes to establish microhabitat areas for wildlife.

Action 1.3.9: Landowners construct fence lines for perching birds in areas that need plant regeneration for grassland restoration and bird and bat boxes to help provide seed dispersal and supplement pest management. They can help mitigate some of the use of insecticides particularly for row crop agriculture. Figure I.1.2 is a diagram of an example nest box design for the American kestrel (Falco sparverius). Figures I.1.3 I.1.4, and I.1.5 are design examples for the western bluebird. Both species are insectivores, although the kestrel will also eat small rodents. Bats utilize agricultural areas to forage for insects and can play an important insect control mechanism. An example design of a single chamber bat house and considerations for bat house placement can be found in Figure I.1.6 Monitoring bird boxes and bat houses is important to their success. They are prone to predation and establishing them may take some time, but resources are available to make adjustments to improve the probability of success (Tatarian, G.).

Birds can also contribute to grassland restoration efforts.

After invasive species are removed through fire, tilling, or

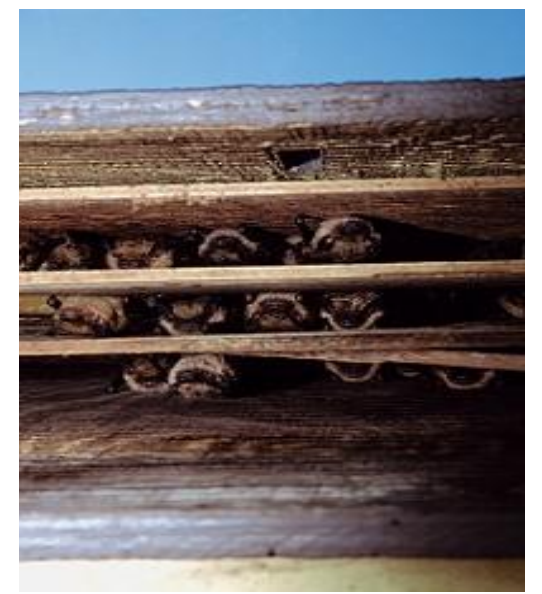

Source: Bat Conservation International herbicides, placing temporary single strand fencing allows places for birds to perch. The scat of seed-eating birds provides nutrients and seeds from neighboring areas. This can be a relatively inexpensive way to establish grassland areas for forage production and/or wildlife habitat (Indiana Division of Fish and Wildlife 2004). 


\section{APPENDIX I Goals, Objectives, Actions and Descriptions}

Figure I.1.2 American Kestrel Next Box Design

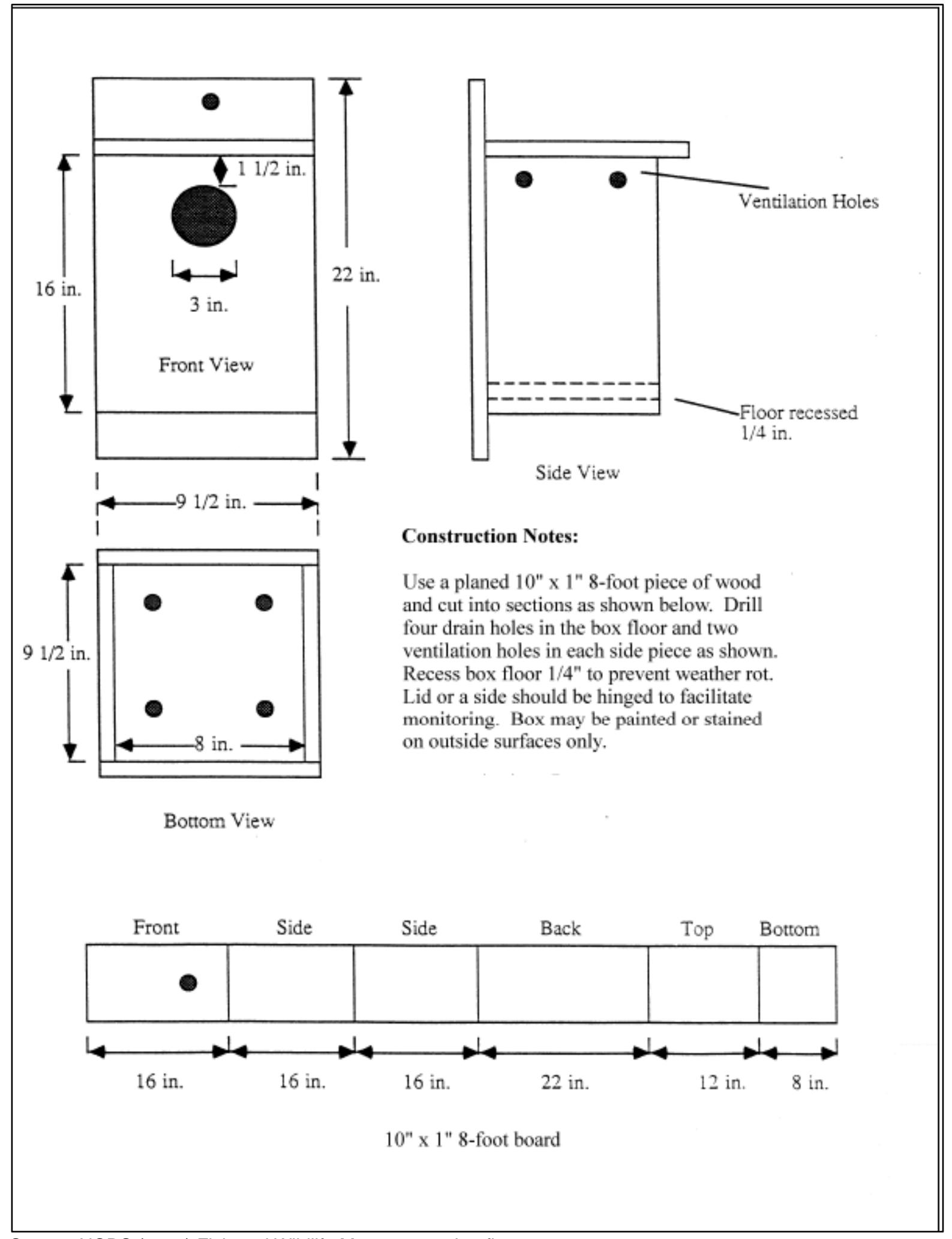

Source: NCRS (1999) Fish and Wildlife Management Leaflet 


\section{APPENDIX I Goals, Objectives, Actions and Descriptions}

Figure I.1.3 Western bluebird next box design - board diagram

\section{MATERIALS LIST}

- Standard board 1" $\times 6$ " $\times$ 4' long

- Standard Board 1" x 10" x 10 1/2" long (for roof)

- 1-3/4" galvanized nails or screws -- approx. 20

- 1-3/4" galvanized screw or nail for pivot point - 2

- Double-headed nail for holding door closed -- 1

\section{BOARD DLORAM}
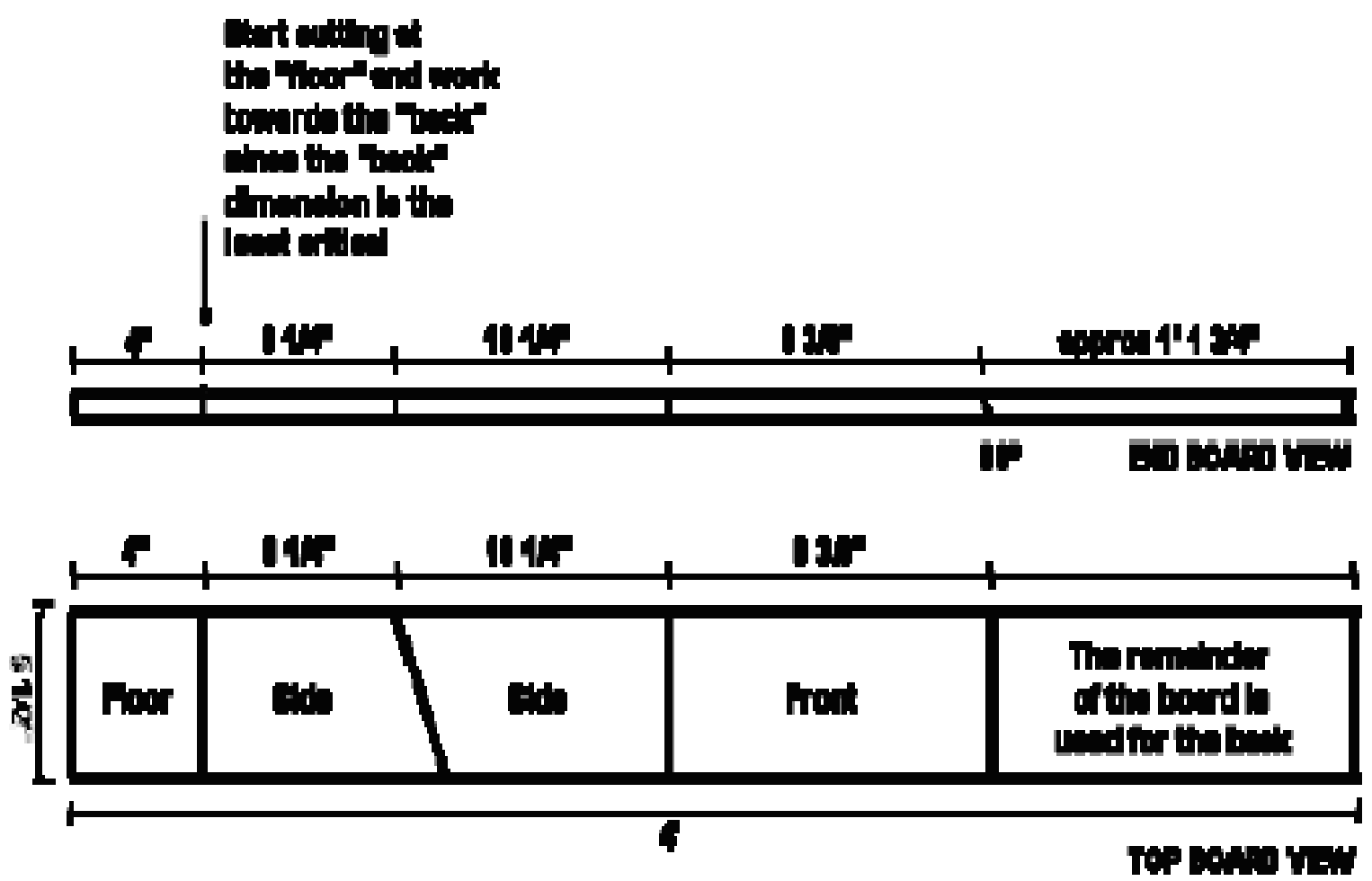

Source: www.nabluebirdsociety.com 


\section{APPENDIX I Goals, Objectives, Actions and Descriptions}

Figure I.1.4 Western bluebird next box design - board diagram

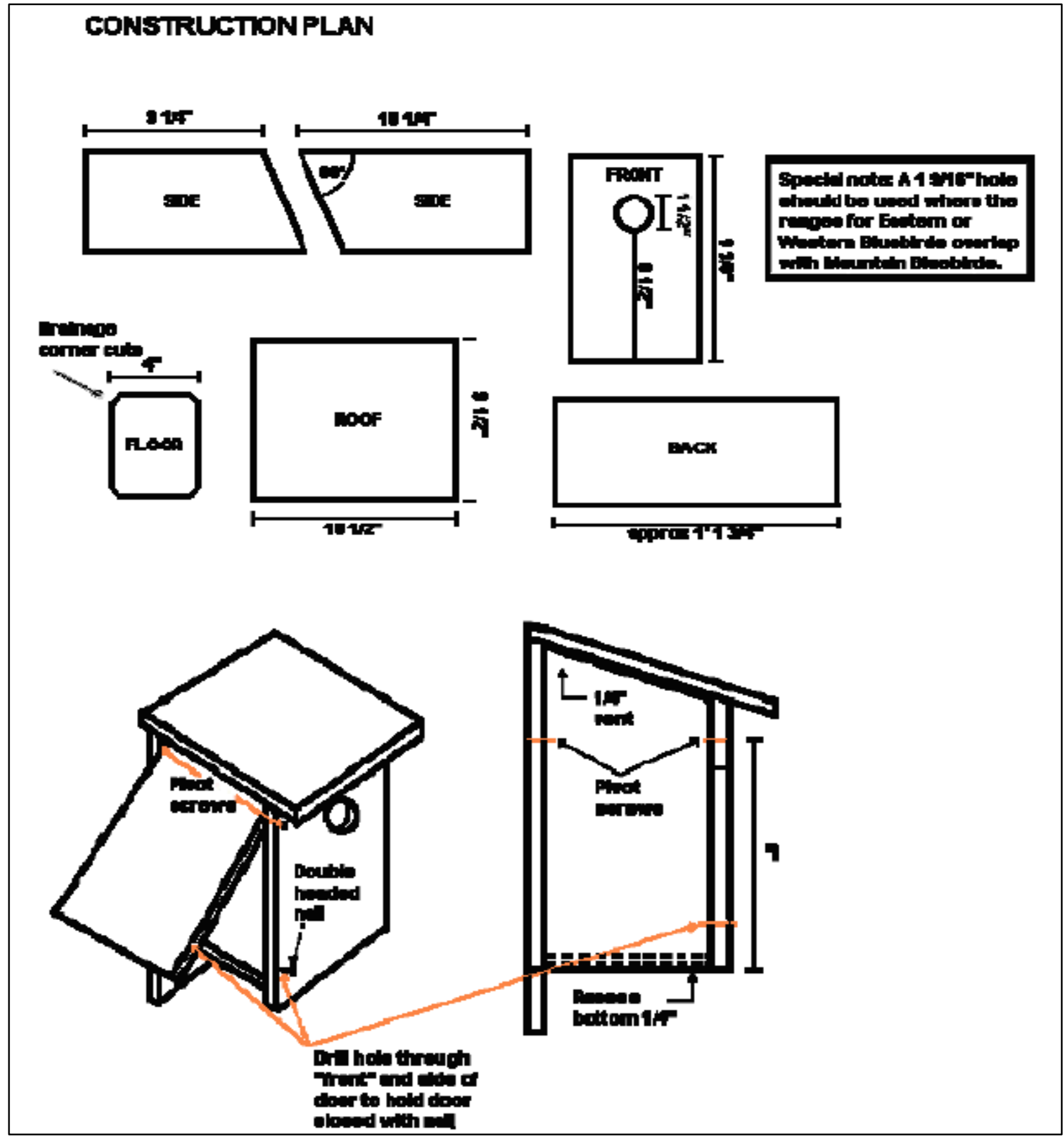

Source: www.nabluebirdsociety.com 


\section{APPENDIX I Goals, Objectives, Actions and Descriptions}

Figure I.1.5 Western bluebird next box design -Front View

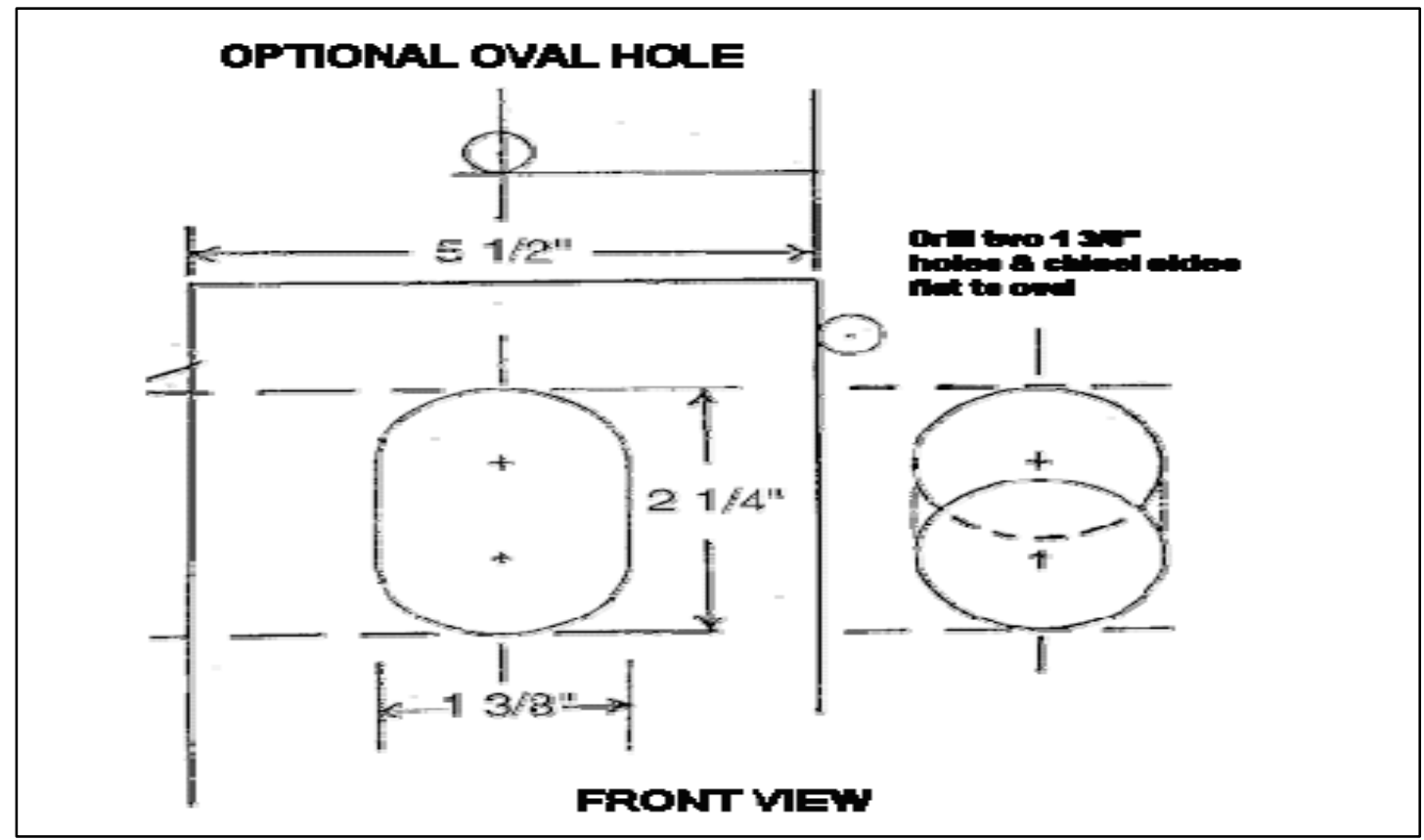

Source: www.nabluebirdsociety.com 


\section{APPENDIX I Goals, Objectives, Actions and Descriptions}

Figure I.1.6 Single-chambered bat box design

\section{Single-chamber Bat House (wall mounted)}

Materials (makes one house)

$3 / 4$ sheet $\left(2^{\prime} x 4^{\prime}\right) 1^{\prime \prime}{ }^{\prime \prime} \mathrm{AC}, \mathrm{BC}$ or T'1-11 (outdoor grade) plywood

One piece $1^{\prime \prime} \times 2^{\prime \prime}\left({ }^{\prime \prime} \times 12^{\prime \prime}\right.$ finished) $x 8^{\prime}$ pine (furring strip)

20 to 30 exterior-grade screws, $1^{\text {" }}$

One pint dark, water-based stain, exterior grade

One pint water-based primer, exterior grade

One quart flat, water-based paint or stain, exterior grade

One tube paintable latex caulk

1" $x 4$ " x 28" board for roof (optional, but highly recommended)

Black asphalt shingles or galva n ized metal (optional)

6 tol0 roofing nails, $7 \mathrm{f}^{\prime \prime}$ (if using shingles or metal roofing)

\section{Recommended tools}

Table saw or handsaw

Variable-speed re versing drill

Scresudriver bit for drill

Tape measure or yardstick

\section{Caulking gun \\ Paintbrushes \\ Hammer (optional) \\ Tin snips (optional)}

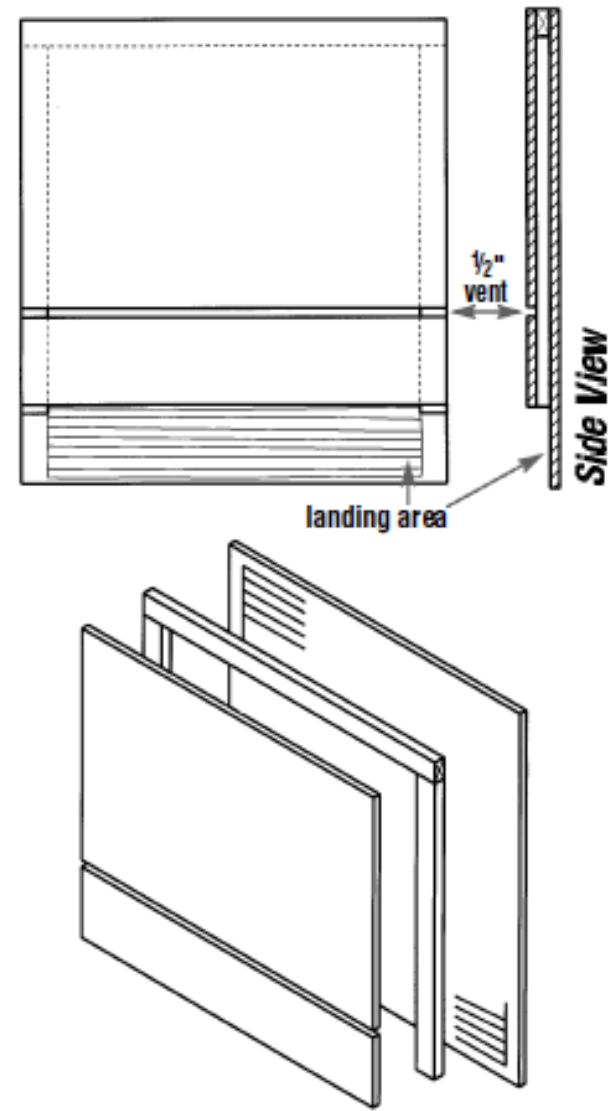

More bat-house plans and additional information can be found in BCl's Bat House Builder's Handbook, available at wwwbatcatalog.com.

\section{Construction}

1. Measure and cut plywood into three pieces: $26 /^{\prime \prime} \times 24^{\prime \prime}$ $161^{\prime \prime} \times 24^{\prime \prime} 5 " \times 24^{\prime \prime}$

2. Roughen inside of backboard and landing area by cutting horimintal grooves with sharp object or saw. Space grooves $\mathcal{X}^{*}$ to $1 / 2 "$ apart, cutting $1 / 2 "$ to $X_{6} "$ deep.

3. Apply two coats of dark, water-based stain to interior sufaces. Do not use paint, as it will fill grooves.

4. Cut furring strip into one $24 "$ and two $20^{1 / 2}$ " pieces.

5. Attach furring strips to back, caulking first. Start with 24 " piece at top. Roost chamber spacing is $\mathrm{z}^{\prime \prime}$.

6. Attach front to furring strips, top piece first (caulk first). Leave $1 / 2$ " vent space between top and bottom front pieces.

7. Caulk all outside joints to further seal roost chamber.

8. Attach a 1" x 4" x 28" board to the top as a roof (optional, but highly recommended).

9. Apply three coats of paint or stain to the exterior (use primer for first coat).

10. Cover roof with shingles or galvanized metal (optional).

11. Mount on building (south or east sides usually best).

\section{Optional modifications to the single-chamber bat bouse}

1. Wider bat houses can be built for larger colonies. Be sure to adjust dimensions for back and front pieces and ceiling strip. A Z $^{\prime \prime}$ support spacer may be needed in the center of the roosting chamber for bat houses over 24 " wide to pre vent warping.

2. To make a taller version for additional temperature diversity, use these modifications: From a $2^{\prime} \times 8^{\prime}$ piece of plywood, cut threxpieces: $51^{\prime \prime} \times 24^{\prime \prime}, 33^{\prime \prime} \times 24^{\prime \prime}$ and $12^{\prime \prime} \times 24^{\prime \prime}$. Cut two $8^{\prime}$ furring strips into one $24 "$ and two 44 " pieces. Follow assembly procedure above.

3. Two bat houses can be placed back-to-back, mounted between two poles, to create a three-chamber nursery house. Before assembly, cut a horizontal $x^{\prime \prime}$ slot in the back of each house about 9" from the bottom edge of the back piece to permit movement of bats between houses. Two pieces of wood, $1 " \mathrm{x}$ $4^{\prime \prime} \times 44^{\prime \prime}$, screwed horizontally to each side, will join the two boxes. Leave a $\mathrm{X}^{\prime \prime}$ space between the two houses, and roughen the wood surfaces or cover the back of each with plastic mesh (see item 5 below). Do not cover the rear exit slots with mesh. One 1" $\times 4$ " x 34" ve rtical piece, attached to each side over the horizontal pieces, blocks light but allows bats and air to enter. A galvanized metal roof, covering both houses, protects the center roosting area from rain. Eaves should be about $3^{\prime \prime}$ in southern areas and about $1 \frac{1}{2} "$ in the north.

4. Ventilation may not be necessary in cold dimates. In this case, the front should be a single piece 23 " long. Smaller bat houses like this one will be less successful in cool climates. However, those mounted on buildings maintain thermal stability better and are more likely to attract bats.

5. Durable plastic mesh can be substituted to provide footholds for bats. Attach one 20" x 24\%" piece to backboard after staining interior, but prior to assembly. 


\section{APPENDIX I Goals, Objectives, Actions and Descriptions}

Objective 1.4: Build partnerships with agencies, organizations and landowners to obtain proper financial and technical resources to plan and implement protection and enhancement projects.

Action 1.4.1: Initial work with willing landowners should include discussions about areas where rehabilitation/improvements can be made. In addition to establishing conservation agreements such as easements, the Conservancy will work with landowners to develop restoration/enhancement project plans to improve wildlife habitat.

Action 1.4.2: Outreach with other agencies and organizations whose priorities are in line with project goals. Willing landowners and the Conservancy will work to establish appropriate partnerships with agencies and organizations who can contribute essential resources and technical expertise to the specific project including help to secure appropriate funding, permit streamlining, project design, and construction.

Action 1.4.3: Help landowners navigate and/or streamline permitting/regulatory processes for restoration and enhancement projects and to be a resource to connect landowners with funding to implement BMPs and new technologies towards land management practices.

\section{Goal 2: Maintain and where feasible, protect and improve a safe and clean water supply}

Objective 2.1: Prevent and reduce upland erosion, runoff, and sedimentation

Action 2.1.1: (528a) Operation owners and land managers should employ a prescribed grazing system based on pre-determined management goals. See Action 1.3.1 above for more details.

Action 2.1.2: (472) Operation owners and managers should utilize livestock exclusion techniques such as fencing in order to protect areas sensitive to erosion and areas that are establishing or reestablishing vegetation. 


\section{APPENDIX I Goals, Objectives, Actions and Descriptions}

Action 2.1.3: (612) Landowners and land managers should work to establish native trees, grasses and shrubs by planting seeds or woody cuttings to help capture sediment and reduce runoff/erosion, improve water quality, and improve biological diversity in appropriate areas.

Action 2.1.4: (345) Operation owners and managers should manage plant residue such as Residual Dry Matter (RDM) to help slow runoff and trap erosion in upland areas.

Action 2.1.5: (484) Operation owners and managers should use mulch in over grazed areas or bare ground areas to control erosion caused by runoff and propagates the growth desirable plant species. Mulching can include most types of organic matter including wood chips, hay, and mixed debris.

Action 2.1.6: Landowners in partnership with restoration specialists and consultants should utilize rip rap where appropriate. Construct a "blanket" of appropriately-sized rock to protect hillslopes, irrigation ditches, channels, and stream banks from erosion. In sensitive habitats plantings should be integrated into rip rap to mitigate for potentially negative effects on wildlife. Figure I.2.1 below is a simple riprap design on a hill slope used to prevent the forming of gullies, sedimentation into streams, rill erosion, etc.

Figure I.2.1 Diagram of riprap construction on a hill slope.

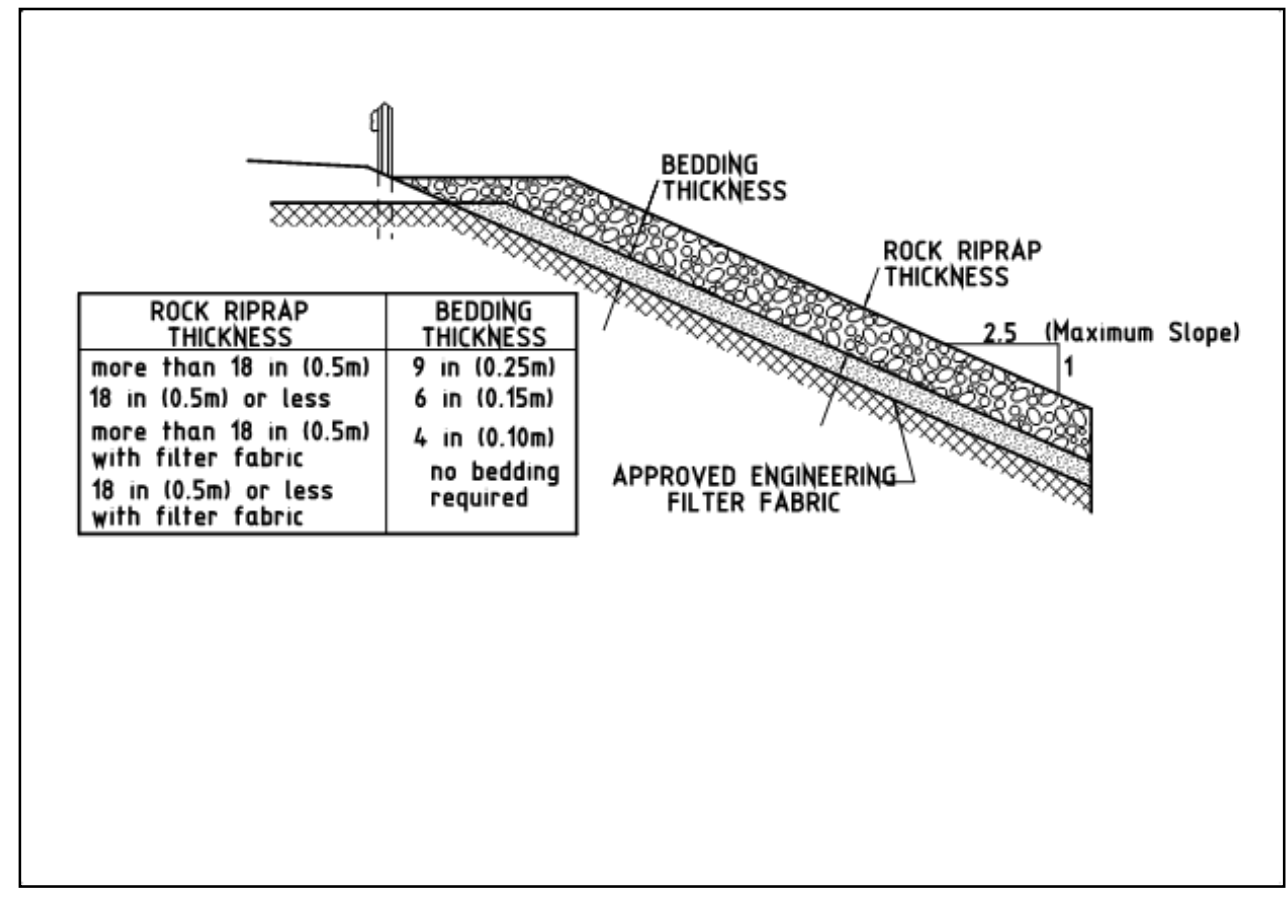




\section{APPENDIX I Goals, Objectives, Actions and Descriptions}

Source: Texas Department of Transportation Hydraulics Design Manual 2009

Action 2.1.7: Landowners in partnership with restoration specialists and consultants should utilize revetments where appropriate. Place material on the banks of ditches, channels, and streams to prevent surface erosion and scour. This practice reduces the potential for mast wasting, protects structures, and improves water quality. Figure I.2.2 is a diagram of a basic revetment design.

Figure I.2.2 Revetment design example

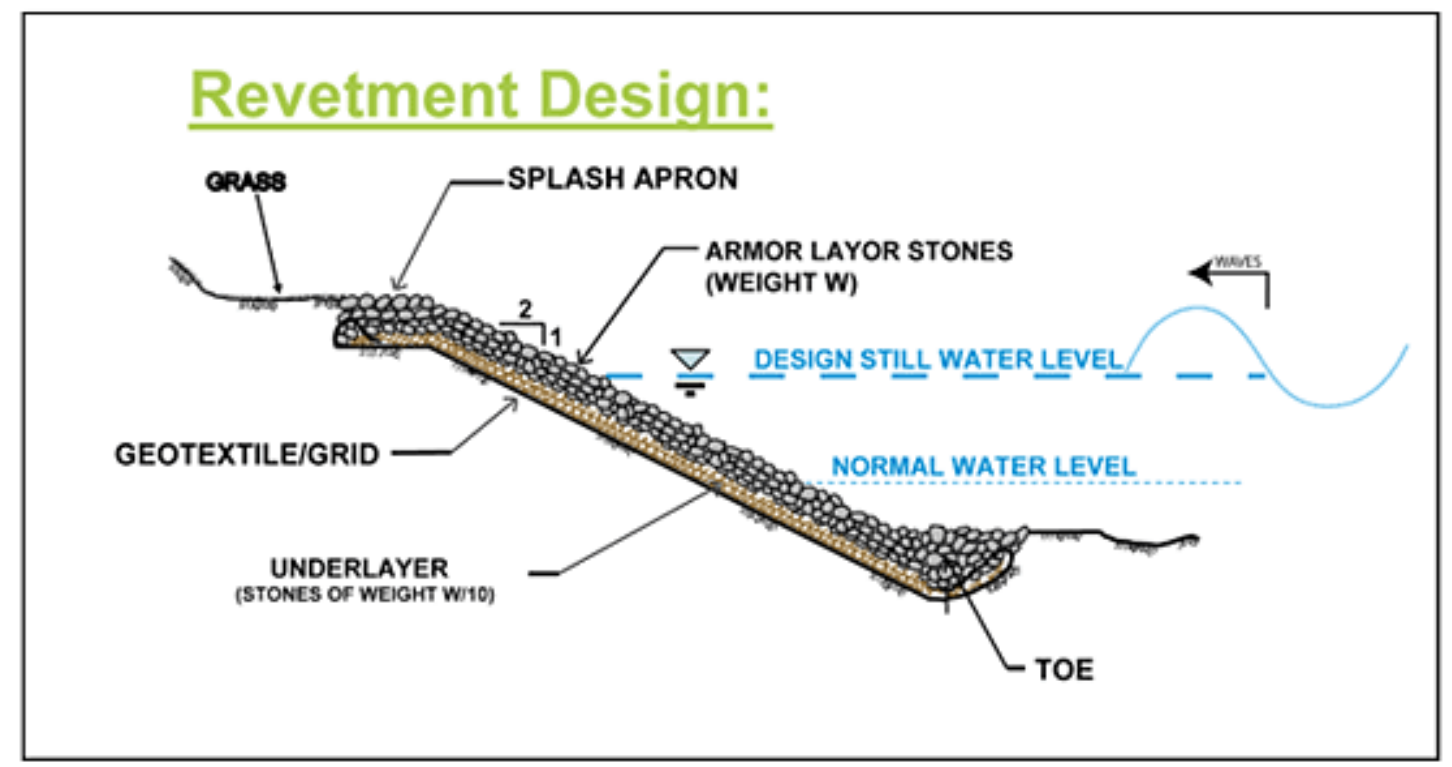

Source: United States Department of Transportation

Action 2.1.8: Landowners in partnership with restoration specialists and consultants should utilize the construction of terraces where appropriate in order to provide a level or slightly concave surface for supporting plant growth, and intercepting surface runoff. This practice shortens slope length to reduce erosion and provides increased infiltration of irrigation water and rainfall. Figure I.2.3 is a diagram of how a conservation bench works in comparison to a slope terrace. 


\section{APPENDIX I Goals, Objectives, Actions and Descriptions}

Figure I.2.3 Conservation bench terrace

\section{LEVEL TERRACE}

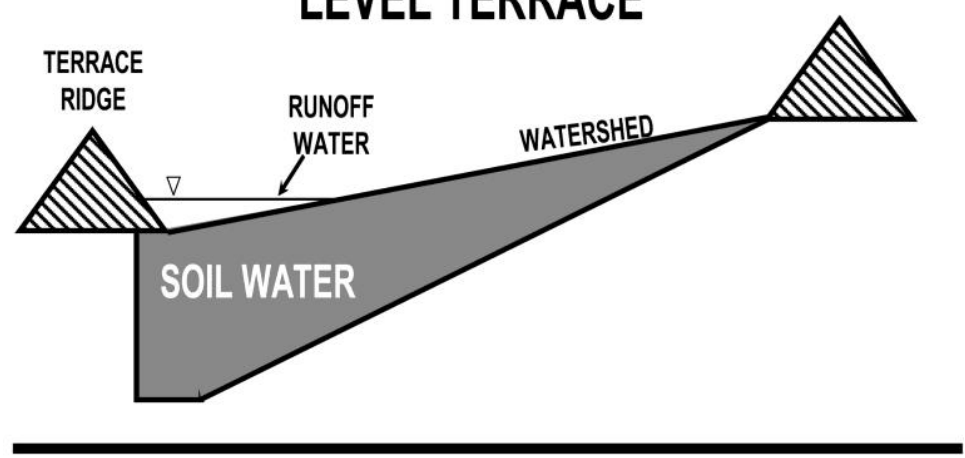

\section{CONSERVATION BENCH TERRACE}

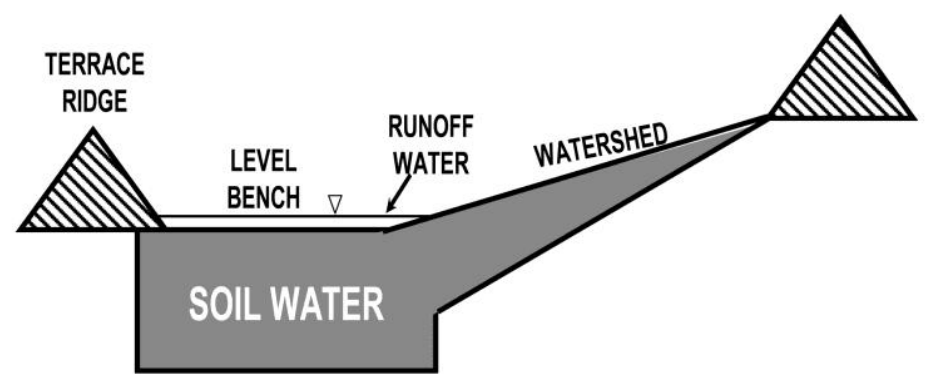

Source: Soil Science Society of America

Action 2.1.9: (560) Landowners in partnership with restoration specialists and consultants should construct access roads and stream crossings, if appropriate, in a manner that prevents and reduces runoff and subsequent erosion into waterways. If cattle must cross streams, construct designated crossing areas, bridges or culverts to reduce the impact of erosion. Access roads are a travel-way constructed to provide a fixed route for vehicular travel for resource activities involving the management of timber, livestock, agriculture, wildlife habitat, and other conservation enterprises. Every effort should be made to reduce the impact that roads have on soil, water, air, fish, wildlife, and other adjacent natural resources. Access roads should be constructed in ways that limit their effect on erosion by generally following topography, way from creeks and streams. Access roads should also avoid going through creeks and streams. Preventative design can avoid erosion problems for example, culverts and bridges can installed to prevent vehicles and equipment from traveling through water ways. There are a lot of factors that go into proper road construction placement, design and maintenance. The goal is to minimize the impact of roads on erosion and subsequent water 


\section{APPENDIX I Goals, Objectives, Actions and Descriptions}

quality resulting from sedimentation. Table I.2.1 below lists primary road design principles relating to drainage and erosion prevention (Kocher et al. 2007). Considerations for road placement are from Keller and Sherar (2003 pg. 23) and include:

- "Using topographic control points and physical features to control or dictate the ideal location of a road. Use saddles in the terrain, follow ridges, and avoid rock outcrops, steep slopes, stream crossings, etc."

- $\quad$ "Locating roads to avoid or minimize adverse affects on water quality and outside of riparian areas and SMZs except at stream crossings. Approach stream crossings at the least gradient possible."

- "Locating roads high on the topography to avoid steep inner canyon slopes and provide for more distance between the road and streams."

- "Locating roads on well drained soils and slopes where drainage will move away from the road."

- "Locating roads to follow the natural terrain by conforming to the ground, rolling the grade, and minimizing cuts and fills."

- "Locating roads, switchbacks and landings on bench areas and relatively flat terrain."

- "Avoiding problematic locations such as springs, wet areas, landslides, steep slopes, massive rock outcrops, flood plains, and highly erosive soils."

- "Avoiding very steep terrain (over 60\%) and very flat terrain where drainage is difficult to control."

\begin{tabular}{|l|}
\hline \multicolumn{1}{|c|}{ Road Design Principles } \\
\hline Construction \\
\hline Reduce the number and length of roads in the watershed \\
\hline $\begin{array}{l}\text { Minimize the width of the area and area disturbed during the } \\
\text { construction phase }\end{array}$ \\
\hline Reduce road gradients. Slope should be 12 percent or less \\
\hline Balanced cut and fill practices \\
\hline Avoid construction on steep slopes (>60 percent) \\
\hline $\begin{array}{l}\text { Minimize cuts, fills and vegetation clearing. Cut slopes should } \\
\text { be on a 0.75:1 or flatter slope }\end{array}$ \\
\hline Build fill slopes on a 1.5:1 or flatter gradient \\
\hline Waterways \\
\hline
\end{tabular}




\section{APPENDIX I Goals, Objectives, Actions and Descriptions}

\begin{tabular}{|l|}
\hline $\begin{array}{l}\text { Stay as far away from streams, wetlands, and other water } \\
\text { sources as possible and minimize crossings }\end{array}$ \\
\hline $\begin{array}{l}\text { Crossings should be designed to pass the } 100 \text { storm flow, } \\
\text { debris and sediment carried through the culvert during a storm }\end{array}$ \\
\hline $\begin{array}{l}\text { Reduce the potential of stream diversion onto the road by } \\
\text { installing dips and trash barriers on streams that do not contain } \\
\text { fish. }\end{array}$ \\
\hline Protect crossing outlets with erosion control measures \\
\hline Facilitate fish passage i.e. using construction of bridges \\
\hline Drainage \\
\hline Provide sufficient road surface drainage to minimize runoff \\
\hline $\begin{array}{l}\text { Out slope roads when possible. three to five percent slop for } \\
\text { road Surfaces on road grades less than ten percent }\end{array}$ \\
\hline Install rolling dips for drainage on out-slope roads \\
\hline $\begin{array}{l}\text { Install ditch relieve culverts for in-slope road services at three to } \\
5 \text { percent slopes. }\end{array}$ \\
\hline $\begin{array}{l}\text { To prevent standing water, crown road sections with gentle } \\
\text { slopes }\end{array}$ \\
\hline Avoid wet and areas prone to erosion \\
\hline Source: Kocher et (2007)
\end{tabular}

Source: Kocher et al. (2007)

Table I.2.1 Road Design Principles

Below are a few examples of commonly utilized drainage and erosion control measures on roads from Kocher et al (2007).

- $\quad$ Ditches collect water from the road surface and on the cut slope side of a road. Culverts provide both stream channel crossings under the road as well as ditch relief off the road. Culverts have environmental impacts associated with them because they may alter the natural channel or require fill in the channel.

- $\quad$ Bridges usually have less environmental impacts than culverts, but are more expensive to construct.

- Low water fords involves the modification of a swale or stream channel to allow vehicles to travel across the stream during low flow periods. They are typically impassable during higher flows and vehicles may contribute to continuous sediment loading in the stream.

- $\quad$ Rolling dips are breaks in the graded road established to drain water directly from the road.

- Water bars are mounds of soil and an adjacent drainage ditch that changes water flow and diverting it off of the road. 


\section{APPENDIX I Goals, Objectives, Actions and Descriptions}

- $\quad$ Armoring is technique where rocks are placed on either the cut or fill slopes or in ditches to prevent water from eroding the soil.

The primary features associated with road design to minimize erosion and improve drainage are the cross-sectional shape and slope of the road as well as determining the type of road needed for the purposes it will serve. Roads with relatively flat gradients are the easiest to maintain as long as the road efficiently drains water. Degree of road usage, all-season roads, and heavy truck traffic require higher design standards. Further resources and more specific information are available by reading the following publications:

- Kocher, S.D., J.M. Gerstein, R.R. Harris. (2007). Rural Roads: A Construction and Maintenance Guide for California Landowners." University of California Division of Agriculture and Natural Resources. Publication 8262.

- Keller, G., and J. Sherar. (2003). Low volume road engineering: Best Management Practices Field Guide. USDA Forest Service/ USAID. National Transportation Library Website, http://ntl.bts.gov/lib/24000/24600/24650/Index BMP Field Guide.htm

- Kramer, B. (2001). Forest Road Contracting, Construction, and maintenance for Small Woodland Owners. Research Contribution No. 35, Corvallis: Oregon State University, Forest Research Library.

Action 2.1.10: (575) Operation owners and managers should work to establish stock trails and pathways in a way that reduces erosion and soil compaction. Heavily used paths by cattle, particularly areas near water, can add to runoff and sedimentation problems. Alleviating pressures on areas that cows favor can be done by spreading water sources, supplement attractants, and rotational grazing systems to ensure that paths are not established and overused, particularly near water sources (Bellows 2003 and Beetz and Rhinehart 2010). Establishing trails should improve grazing distribution and be an integrated part of a prescribed grazing system. Access for cattle may work to reduce concentrations of livestock in a particular area and facilitate appropriate utilization of a pasture/grazing area.

Action 2.1.11: (453) Landowners in partnership with restoration specialists and consultants should identify areas with existing and potential erosion problems and apply treatments to prevent and/or stabilize landslides to stop excessive erosion and sedimentation. Common ways to prevent landslide hazards include regeneration/planting of vegetation. Root systems hold 


\section{APPENDIX I Goals, Objectives, Actions and Descriptions}

soil, prevent erosion, and create soil stability. Plants can also help to intercept precipitation and prevent runoff and excessive infiltration. Establishing a drainage system can prevent excessive storm-water from saturating the ground. Drains can move water away from hazard prone areas. Slope stabilizing material can also be used by grading and infilling lower areas, using erosion mats/blankets, plastic sheeting or other erosion-control mechanisms directly on the slope. This is particularly useful while vegetation is regenerating or where vegetation cannot be established. Setback for any property structural improvements appropriately assessed and implemented to provide a safety buffer near potential hazardous areas (NRCS Planning and Design Manual).

Action 2.1.12: (603) Landowners and land managers should work to establish herbaceous vegetation wind barriers in rows or narrow strips in the field across the prevailing wind direction to reduce wind erosion, protect crops from dust, and to provide food and cover for wildlife.

Objective 2.2: $(391,393)$ Maintain and/or improve riparian buffers along streams, wetland, vernal pools, etc.

Action 2.2.1: (528a) Operation owners and managers should employ a prescribed grazing system based on pre-determined management goals. See Action 1.3.1 above for more details.

Action 2.2.2: (472) Operation owners and managers should utilize Livestock exclusion techniques to protect riparian corridors. Riparian areas are excluded from livestock grazing in the pasture. Livestock exclusion helps to protect seedlings from effects of livestock such as browse, rubbing, and soil compaction. The wider the riparian corridor, the greater the impact it has in capturing and storing sediment and other non-point source pollution, which improves water quality. See Action 1.3.2 above for a more details.

Action 2.2.3: Operation owners and managers should utilize alternative water sources where available such as stock ponds, well development, spring development troughs. Conveyance systems can be established to pump water from one source to another. Proper placement i.e. consideration of distance between water sources and forage areas should be part of the planning and implementation of alternative water sources. In a report by Hart et al. (1989) the distance to water had no effect on pasture and rangeland utilization in areas 60 acres or smaller 


\section{APPENDIX I Goals, Objectives, Actions and Descriptions}

that were being continuously or on a rotational grazing system. On larger areas, utilization of available forage declines when cattle have to travel further to water. It is then encouraged to develop/provide water sources within optimal distances of available forage areas in order to encourage optimal utilization of pasture areas (Gerrish et al.). Optimal utilization not only helps keep operational costs down, but it also more evenly distributes nutrients around to promote regeneration of habitat for grassland wildlife, keeps cattle away from riparian habitat areas, and also provides forage for wild ungulate species such as Elk and Mule Deer.

Action 2.2.4: (612) Landowners and land managers should plant native, trees, and shrubs to establish a vegetation canopy and sub canopy species. This is particularly important for riparian buffers. Generally the wider the buffer, the more protection is provided to the surface water source from pollutants and sedimentation, which increases water quality. Planting vegetation in riparian areas involved actively planting plants or seeds to reestablish riparian corridors. Typically, essential riparian species such as willows and cottonwood are planted first to initiate plant regeneration and utilize immediate benefits such as stream shading and sediment control. Irrigation maybe required for newly planted vegetation to provide hydration while their root systems are establishing. Some re-vegetation projects may require initial soil stabilizing techniques such as the use of mulch, bank stabilization, straw wattles, and other mechanisms to control erosion while plants are regenerating. Active management during regeneration of vegetation may also be required to control noxious weed invasion which can slow and/or harm newly planted native vegetation. Riparian restoration plans should incorporate natural recruitment of native species to cut down on labor and costs and relies on seed dispersal, floodplain inundation and seedling establishment.

Action 2.2.5: (412) Landowners in partnership with restoration specialists and consultants should identify areas needing erosion control measures and implement grassed waterways if appropriate. Construct channel with established vegetation suitable for carrying surface water in a non-erosive manner to a stable outlet. Waterways should generally have less than five percent slopes, be suitable for vegetation and be supported by adequate vegetation. Water must be restricted from flow in the channel while vegetation is establishing. Grass may become ineffective as a sediment reduction device in stream if there is too much buildup of sediment in the channel. Sharp changes in channel direction or grade should be avoided and consideration for the development of gullies or overfalls should be taken into account before the installation of 


\section{APPENDIX I Goals, Objectives, Actions and Descriptions}

vegetative structures. Disturbed areas should be seeded and mulched as quickly as possible and ideal planting should take place during growing season. Plant anchoring by way of mulching, or bale dikes maybe necessary to help plants become established. Enough time should be allotted between having no flow in the channel and establishment of the vegetation. Additional riparian buffers may be necessary for grassed waterways adjacent to construction sites to intercept large quantities of sediment. Any projects larger than ten acres in size, it is recommended that the organization or landowner consult by an engineer with waterway design experience (NRCS Planning and Design Manual). Design criteria for grassed waterways according to the NCRS Planning and Design Manual includes:

- Capacity - The minimum capacity for a grassed waterway shall be that required to convey the peak runoff expected from a storm of 10-year frequency, 24-hour duration. When slope is less than 1 percent, out of bank flow may be permitted if such flow will not cause excessive erosion or cause damage to houses, buildings, or other important features.

- Velocity - Design velocities shall be calculated using Manning's formula and standard procedures for determining " $n$ " values of tall and short grasses. Design velocities with mature vegetation in grassed waterways shall not exceed $5 \mathrm{ft} / \mathrm{s}(1.5 \mathrm{~m} / \mathrm{s})$. Good vegetal cover, mulch netting, temporary gully barriers, and proper maintenance will be needed to establish and maintain waterways having velocities approaching $5 \mathrm{ft} / \mathrm{s}(1.5 \mathrm{~m} / \mathrm{s})$.

- Width - Grassed waterways may be parabolic, trapezoidal, or "V" shaped. The bottom width of trapezoidal waterways shall not exceed $50 \mathrm{ft}(15 \mathrm{~m})$ unless multiple or divided waterways or other means are provided to control meandering of low flows.

- $\quad$ Side Slopes - Side slopes shall not be steeper than a ratio of three horizontal to one vertical to facilitate use of mowing and maintenance equipment. Side slopes of 4:1 or flatter are recommended.

- Depth - The minimum depth of a waterway that receives water from other tributary channels shall not create backwater in that channel when both are flowing at design depth. A minimum of $0.3 \mathrm{ft}(91 \mathrm{~mm})$ shall be added to the design depth for freeboard.

- Drainage - Subsurface drains, underground outlets, stone center waterways, or other suitable measures shall be provided for in the design for sites having prolonged flows, a high water table, or seepage problems. 


\section{APPENDIX I Goals, Objectives, Actions and Descriptions}

- $\quad$ Outlets - All grassed waterways shall have a stable outlet with adequate capacity to prevent ponding or flooding damage. The outlet can be another vegetated channel, an earth ditch, a grade stabilization structure, or other suitable outlets.

- Establishment of Vegetation - Grassed waterways will be vegetated according to practice standard for seeding and mulching.

- Maintenance - A maintenance program shall be established to maintain waterway capacity, vegetative cover, and the outlet. Vegetation damaged by traffic, herbicides, or erosion must be repaired promptly.

Action 2.2.6: (345) Operation owners and managers should manage plant residue such as Residual Dry Matter (RDM) to help slow runoff and trap erosion in upland areas. RDM allows land managers to estimate of the amount of above ground plant material. RDM typically is an assessment of residual plant matter at the start of the growing season, but can also be assessed after grazing events. Residual plant material describes vegetation amount, species composition and quality with regard to the health of the soil surface. The amount of RDM provides information on a number of management issues including: grazing management strategies (timing, frequency and intensity), agricultural practices, natural degradation, and impacts from wildlife or by humans (Drake, D.J.).

A specific and localized prescribed grazing management system catered to determined management objectives along with other management practices such as weed control can help to achieve desired RDM rates. Bartolome et al. 2002 developed regional minimum RDM guidelines and are outlined in Tables I.2.2, I.2.3, I.2.4.

\begin{tabular}{|c|c|c|c|c|}
\hline \multirow{2}{*}{$\begin{array}{l}\text { Percent } \\
\text { woody cover }\end{array}$} & \multicolumn{4}{|c|}{ Percent slope } \\
\hline & $0-10 \%$ & $10-20 \%$ & $20-40 \%$ & $>40 \%$ \\
\hline $0-25$ & 300 & 400 & 500 & 600 \\
\hline $25-50$ & 300 & 400 & 500 & 600 \\
\hline $50-75$ & NA & NA & NA & NA \\
\hline $75-100$ & NA & NA & NA & NA \\
\hline
\end{tabular}

Source: Bartolome et al. 2002

Table I.2.2 Minimum RDM guidelines for dry annual grassland. 


\section{APPENDIX I Goals, Objectives, Actions and Descriptions}

\begin{tabular}{|lcccc|}
\hline \multirow{2}{*}{ Percent } & \multicolumn{4}{c|}{ Percent slope } \\
\cline { 2 - 5 } & $\mathbf{4} \mathbf{- 1 0} \%$ & $\mathbf{1 0 - 2 0} \%$ & $\mathbf{2 0 - 4 0 \%}$ & $>\mathbf{4 0} \%$ \\
\hline $0-25$ & 500 & 600 & 700 & 800 \\
$\mathbf{2 5 - 5 0}$ & 400 & 500 & 600 & 700 \\
$50-75$ & 200 & 300 & 400 & 500 \\
$75-100$ & 100 & 200 & 250 & 300 \\
\hline
\end{tabular}

Source: Bartolome et al. 2002

Table I.2.3 Minimum RDM guidelines for annual grassland/hardwood range

\begin{tabular}{|lcccc|}
\hline \multirow{2}{*}{ Percent } & \multicolumn{4}{c|}{ Percent slope } \\
\cline { 2 - 5 } & $\mathbf{0 - 1 0 \%}$ & $\mathbf{1 0 - 2 0 \%}$ & $\mathbf{2 0 - 4 0 \%}$ & $>\mathbf{4 0} \%$ \\
\hline $0-25$ & 1,200 & 1,500 & 1,800 & 2,100 \\
$25-50$ & 800 & 1,000 & 1,200 & 1,400 \\
$50-75$ & 400 & 500 & 600 & 700 \\
$75-100$ & 200 & 250 & 300 & 350 \\
\hline
\end{tabular}

Source: Bartolome et al. 2002

Table I.2.4 Minimum RDM guidelines for coastal prairies

Action 2.2.7: (484) Landowners and land managers should use mulch in over grazed areas or bare ground areas to control erosion caused by runoff and propagates the growth desirable plant species. Mulching can include most types of organic matter including wood chips, hay, and mixed debris. According to the Natural Resource Conservation Service (2005), "Mulches are products that are placed on the soil surface to improve conditions for seed germination (nutrient regulation and establishment, retaining water moisture and controlling surface temperature), decreases evaporative losses, reduce weed competition, and/or improve soil stability." Desirable plant species can be spread in combination with mulch can held down by a mulch-tackifier mix. Other erosion control methods include:

- Straw spreading and blowing is the least expensive mulching technique. Straw is broadcast manually or by machine. Blowers or wind blast machines make it easier to mulch slopes. This method requires good access to the site. Straw should be anchored and can done by utilizing one or more of the following: 


\section{APPENDIX I Goals, Objectives, Actions and Descriptions}

- Cat walking with cleats

- A sheep's-foot roller behind a tractor or front-end loader

- Empty drill with heavy press wheels

- Spiral rollers - less effective against wind erosion

Application rates vary but generally fall between 1,000 and 8,000 pounds per

acre. More straw provides better erosion protection, but will inhibit plant regeneration. According to NCRS, "some soil should be visible if plant growth is needed." Excessive straw can also attract/shelter rodent species. (NRCS 2005)

- Hydromulching utilizes a combination of tackifier and organic mulching material. The mixture may also contain seed and/or fertilizer. Hydromulching has the ability to reach inaccessible areas. Application rates vary between 500 and 3000 pounds per acre. Approximately 1000 gallons of water is needed for every 500 pounds of wood fiber. (NRCS 2005)

- Erosion mats are typically used on slopes where the probability of severe water erosion is probable. Fiber manufactures provide anchoring/pinning recommendations. If revegetating an area, cattle and foot traffic should be kept out until vegetation has been established. Typical application of mats includes one layer with twelve inch space of overlap where mats come together. Pins and stakes are placed 2-5 feet apart. Typically more pins are needed for steeper slopes. (NRCS 2005)

- Rock and gravel facing helps to stabilize soils with a high probability of erosion. Rock and gravel are heavy and costly to move. Typical application rates vary between two and three inches deep which is equal to about 300 to 400 tons of rock or gravel per acre. (NRCS 2005)

Several different types of mulch can be used to control erosion and help set seed. Some are better than others and it depends on the specific situation.

- Wood/bark mulch have an easy application and using the right amount can significantly reduce water evaporation and reduce erosion. They also have high carbon to nitrogen ratios. This means that nitrogen in the soil will be unusable to plants, which can be beneficial. Many desirable plants do not respond well to high nitrogen levels where some noxious weed species do. Locking up nitrogen in the soil can prevent establishment of noxious weeds by shading them out and preventing them from getting 


\section{APPENDIX I Goals, Objectives, Actions and Descriptions}

the nutrients they need. However, wood and bark mulch are less effective per unit weight than straw mulching and can discourage desirable plant growth if used in excess.

- Compost material can also be utilized as a mulch and has a higher nutrient content than raw organic material. Compost can be particularly advantageous on soils devoid of nutrients and vegetation. Mixing in compost can reestablish nutrients into the soil which can help establish vegetation growth.

- Wood and straw mats are made from chemically deteriorated filaments that are constructed to make porous mats or blankets. This material is easily installed and is efficient at providing soil erosion protection. There is some significant site preparation for the use of mats. Mats are rolled out and staked down to the soil using wooden stakes or wire. Mats typically degrade in 24 months of application. Mats are manufactured with a polymer netting and will degrade in sunlight. It is important to select an appropriate polymer netting because degradation rates vary.

- Wood and straw pellets produced under a similar process to filaments only shaped as pellets instead. Less site preparation is necessary for the use of pellets and they can be easily broadcasted.

- Coconut fiber is typically sold as mats and is easily installed on smooth soils. They are efficient and short term soil protection.

- $\quad \underline{S t r a w}$ is readily accessible in the Upper Salinas watershed region. It is relatively inexpensive, durable and has an easy application. It is particularly efficient at protecting soil against wind erosion. For maximum benefit against wind and water erosion, straw mulch should be anchored down.

- $\quad$ Tackifiers have adhesive properties that when combined with organic mulches can help anchor mulches to the soil. Hydromulching is a common mulching process that utilizes tackifiers.

- $\quad$ Polymers are inorganic compounds that alter soil properties. Water-soluable polymers such as PAM binds soil particles. Suspended in water, these particles then settle out and therefore efficient at protecting from water erosion.

- $\quad$ Rock mulching can also be utilized to dissipate the energy created by flowing and falling water particles, therefore protecting the soil from the erosion effects of caused by the movement of water. 


\section{APPENDIX I Goals, Objectives, Actions and Descriptions}

Action 2.2.8: (350) Landowners in partnership with restoration specialists and consultants should develop sediment basins in areas where increased erosion and sedimentation can be prevented from entering streams if appropriate. Sediment basins are temporary and constructed by excavating and building an embankment so that runoff and associated sediment is trapped, allowing the sediment to settle out before the runoff discharged (Caltrans 2003). Retention basins do not allow water to discharge with the exception of a high water retention relief valve. Water then can escape through evaporation and evapotranspiration. In a region that does not receive much rain in the late spring, summer, and fall, retention basins can serve dual purposes as both a stock pond and a sediment catchment system. Figure I.2.4 is a diagram of a single orifice sediment basin

Figure I.2.4 Single Orifice Sediment Basin Design

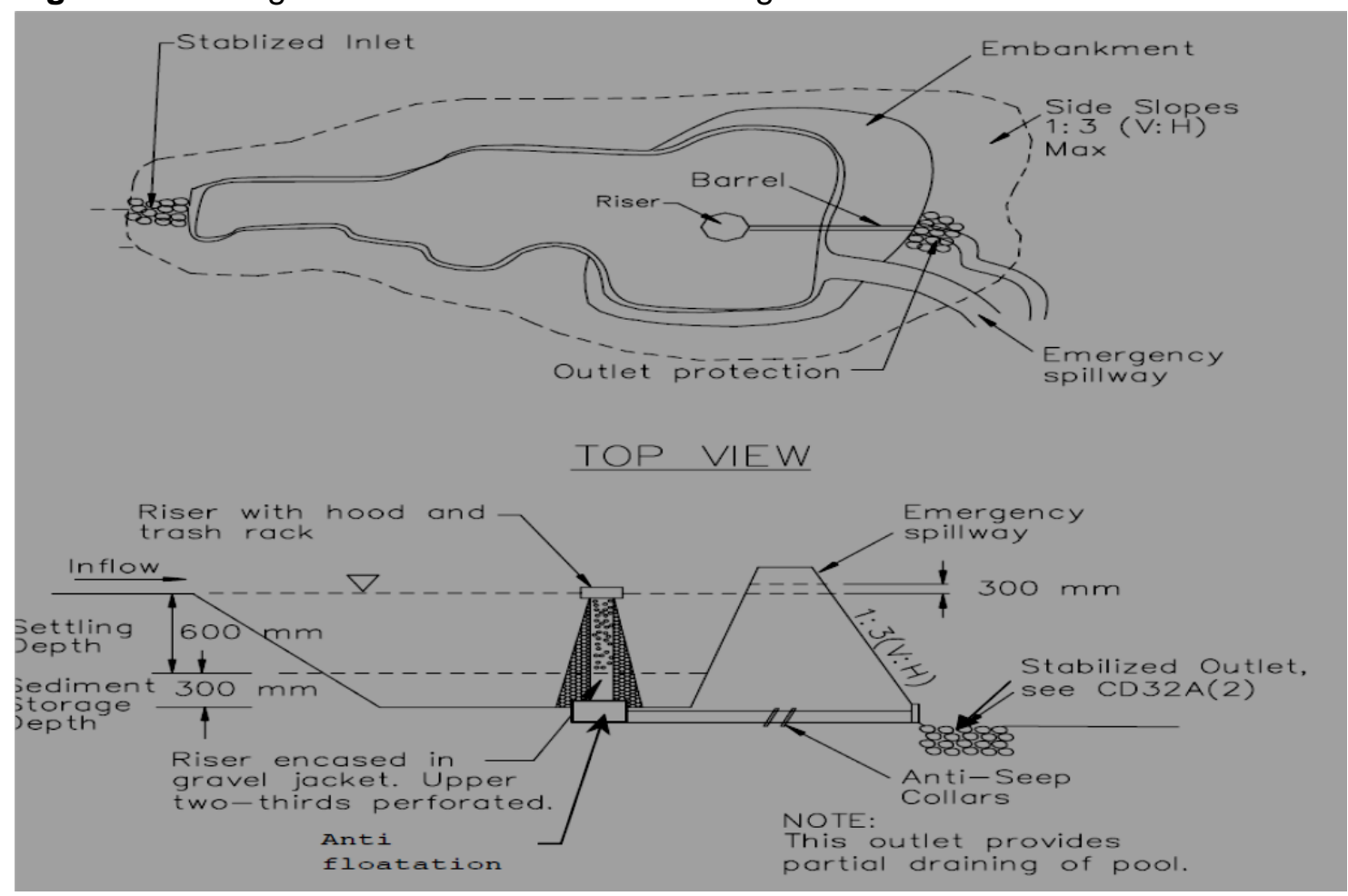

Source: Caltrans (2003)

Action 2.2.9: Landowners in partnership with restoration specialists and consultants should construct waste treatment lagoons, if appropriate to trap livestock waste water and keep it from reaching creeks or streams. Construct ponds using an embankment or digging a pit with the purpose of intercepting waste discharge/runoff from facilities such as confined animal 


\section{APPENDIX I Goals, Objectives, Actions and Descriptions}

operations with the intent of biologically treating waste, such as manure and wastewater, thus reducing pollution in sensitive waterways.

Action 2.2.10: $(378,574,453,642)$ Operation owners and managers should develop stock ponds, springs, wells and troughs to keep cattle out of managed areas. Water sources for livestock set away from riparian areas can protect habitat and prevent increased non point source pollution sources from entering water source. Developed alternative water sources can come from irrigation and stream diversion, well development, spring development and rain water coinciding with developed stock ponds, troughs and tanks. Pump stations (533B and 533C) are required when gravity fed options are not available. Some ranchers use solar powered pumps which provide a viable source of energy if water needs to be pumped.

Stock ponds troughs and tanks can provide livestock with water sources throughout range and help keep cattle dispersed and away from riparian areas. Stock tanks and troughs are manufactured and can be place throughout the range. Tanks and troughs can be filled through manual filling from a tank truck, piping water from a water source, and/or rainwater. Stock ponds need to be excavated and can be built to any desired shape. Figure I.2.5 is a diagram of a well and stock pond piping system. Rectangular shapes are popular because of their ease to build and are adaptable to all kinds of excavating equipment. The side slopes of the pond should be as flat as possible. This allows livestock easy access to the water sources unless the pond is planned to be fenced and equipped watering troughs located away from the pond site. The side slopes should be as flat as possible for easy access of the livestock unless the pond is planned to be fenced and equipped with external watering troughs (Food and Agricultural Organisation of the United Nations 2011).

Fencing should cover the perimeter of the pond to avoid trampling damage particularly during the revegetation stage around the pond to prevent soil compaction and water pollution. A subsequent watering system should be installed outside the fenced area and gravity fed (piping running below the bank of the pond) or pumped to water troughs. Maintenance will be required as cattle utilize the area resulting in an increase in the flow of sediment into the pond reducing the ponds ability to hold useable water. Dredging maybe necessary every 4 to 5 years depending on the depth of the pond (Food and Agricultural Organisation of the United Nations 2011). 


\section{APPENDIX I Goals, Objectives, Actions and Descriptions}

Figure I.2.5 Example of a Well and stock pond piping system

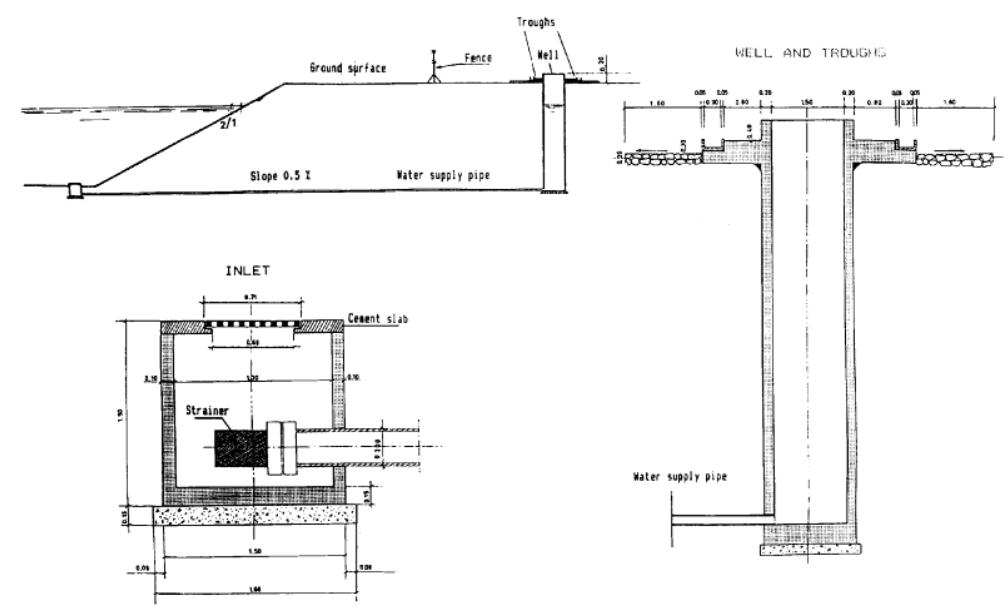

Source: FAO 2011

Spring Development spring development is a relatively cheap method of off stream water development, if springs are present. Depending on the size of the spring, it may be able to supply water to more than one pasture. Figure I.2.6 and I.2.7 are examples of spring and seep development on rangeland. Some of the costs include:

- digging equipment

- gravel

- pipping

- $\quad$ spring box

- permit 


\section{APPENDIX I Goals, Objectives, Actions and Descriptions}

Figure I.2.6 Spring development for livestock

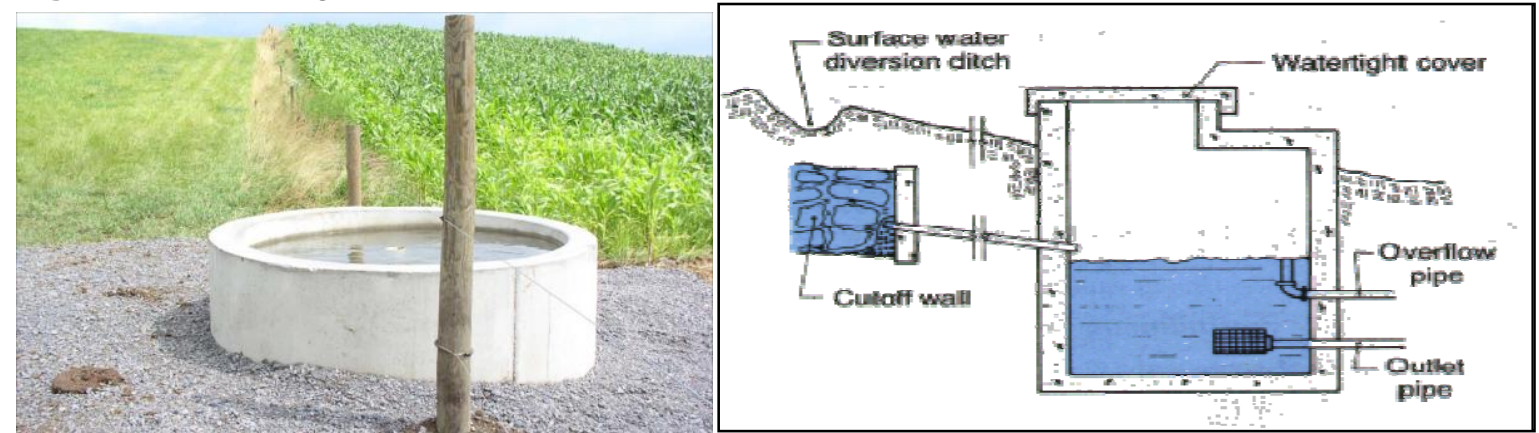

Source: Natural Resource Conservation Service

Figure I.2.7 Seep development

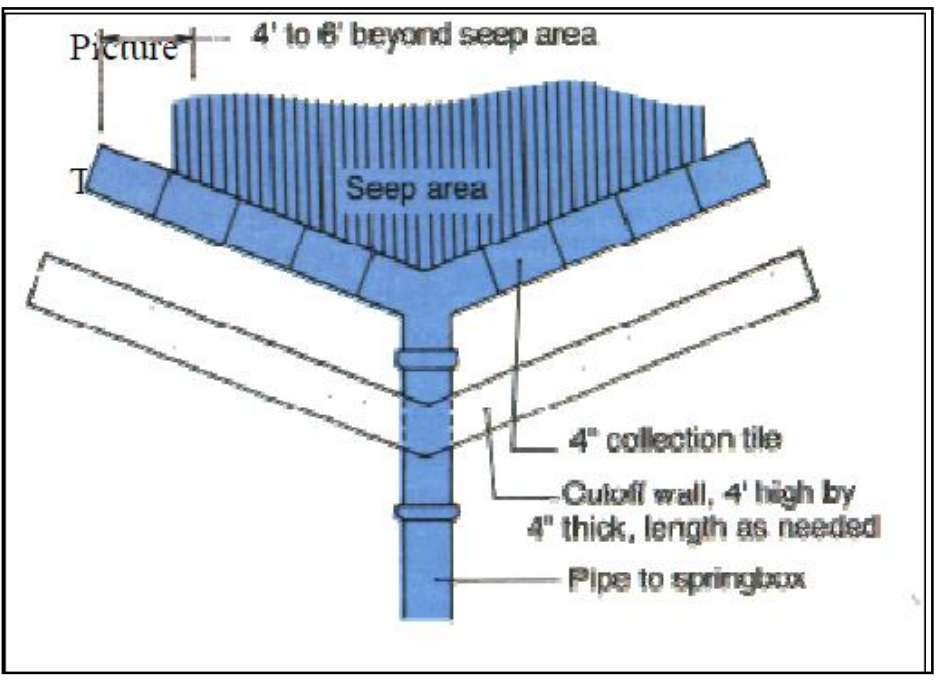

Source: Natural Resource Conservation Service

Well Development can help tap into ground water resources. Solar powered pumps can help pump water from wells and send water to off stream trough and tank sites (Macon 2002).

Action 2.3.1: Operations owners and/or managers should place sharp rocks in in-stream cattle crossings to make it uncomfortable for cattle to stay in the stream or wetland area.

Action 2.2.11: (575) Operation owners and managers should limit the creation and use of cow paths, which increases erosion and subsequent sedimentation. See Action 2.1.10 for more details. 


\section{APPENDIX I Goals, Objectives, Actions and Descriptions}

Action 2.2.12: (410) Landowners in partnership with restoration specialists and consultants should work to stabilize the grade and control erosion in channels using a structure to prevent the formation and advancement of gullies, enhance environmental quality, and reduce pollution hazards.

Gullies form upslope at overall areas below where turbulent water is concentrated and causes head-cutting. Grade stabilization structures control how and where water falls, concentrating them at lower elevations which prevent the creation of upland gullies from forming and advancing. There are many types of grade stabilization structures from full-flow spillways to water detainment systems. Erosion prone sites such as a confluence where a tributary or drainage outlet enters a stream or river channel. Water flow is slowed from the higher elevations. Typically a combination of practices and techniques are used to complement each other and increase structural effectiveness. Structures will last longer and work best when upland runoff is controlled by employing practices such as contour farming, conservation tillage, the use of sediment basins, terraces, cover crops, rotational grazing, and grass planting (Minnesota Department of Agriculture 2011). There are many benefits to stabilization structures including (Minnesota Department of Agriculture (2011):

- Reduction of soil erosion and prevention of gullies

- Reduction of peak stormwater flows

- Protection of water quality by reducing sediment from entering the system

- Wildlife protection by protecting water quality

- Wildlife enhancement; structures with water storage provide a source of water to wildlife

- Prevents productive topsoil from being eroded away

- Prevents creation of gullies that make areas potentially dangerous for cattle and can create difficulties to farming

- Minimizes gully repair costs

- Prevents siltation of cropland and roadways.

The complexity of grade stabilization structures typically requires detailed site investigations. Large structures (>100 cfs, storing $>50$ acre-ft of water or more than 15 feet in total height) - requires the consultation of a qualified engineer experienced in hydraulics and structure design. Advice on the control of stream channel erosion can be obtained from the local USDA NRCS office. There are many types of grade control structures from the simple to the more complex. Examples of grade control structures include:

- Riprap, sheet piling 


\section{APPENDIX I Goals, Objectives, Actions and Descriptions}

- Lumber, logs, gabions

- Compacted earthfill

- Baffle plates and sills

Factors that determine the type and specific design specifications of grade control structures includes:

- Hydraulic conditions

- Sediment size and loading

- Channel morphology

- Flood plain and valley characteristics

- Material availability

- Project objectives

- Timing and funding constraints

Table I.2.5 is a list of common grade stabilization techniques and their advantage and disadvantage according to NRCS (2007). Table I.2.5 below does not list every technique available and site specific considerations are essential to the success of stabilization structures.

\begin{tabular}{|c|c|c|}
\hline Structure type & Advantages & Disadvantages \\
\hline Loose rock structures & $\begin{array}{l}\text { Economical to design and build } \\
\text { Limited environmental impacts } \\
\text { Ease of construction }\end{array}$ & $\begin{array}{l}\text { Generally limited to less than about } 3 \mathrm{ft} \text { drop } \\
\text { heights } \\
\text { Potential for displacement of rock due to seepage } \\
\text { flows }\end{array}$ \\
\hline Channel linings & $\begin{array}{l}\text { Provides for energy dissipation through the } \\
\text { structure } \\
\text { Can be designed to accommodate fish passage }\end{array}$ & $\begin{array}{l}\text { Significant design effort } \\
\text { Relatively high cost } \\
\text { Larger construction footprint due to length of } \\
\quad \text { structure }\end{array}$ \\
\hline $\begin{array}{l}\text { Loose rock structures } \\
\text { with water cutoff }\end{array}$ & $\begin{array}{l}\text { Provides positive water cutoff that eliminates } \\
\text { seepage problems and potential for rock } \\
\text { displacement } \\
\text { Higher drop heights (up to about } 6 \mathrm{ft} \text { ) }\end{array}$ & $\begin{array}{l}\text { More complex design required } \\
\text { Higher construction cost than simple loose rock } \\
\text { structures } \\
\text { More potential for fish obstruction at higher drop } \\
\text { heights }\end{array}$ \\
\hline $\begin{array}{l}\text { Structures with } \\
\text { preformed scour holes } \\
\text { and water cutoffs }\end{array}$ & $\begin{array}{l}\text { Improved energy dissipation } \\
\text { Scour holes provide stable reproductive habitat } \\
\text { Higher drop heights (up to about } 6 \mathrm{ft} \text { ) }\end{array}$ & $\begin{array}{l}\text { Larger construction footprint } \\
\text { More complex design effort required } \\
\text { Increased construction cost } \\
\text { More potential for fish obstruction at higher drop } \\
\text { height }\end{array}$ \\
\hline Rigid drop structures & $\begin{array}{l}\text { Can accommodate drop heights greater than } 6 \mathrm{ft} \\
\text { Provides for energy dissipation } \\
\text { Single structure can influence long reach of } \\
\text { stream }\end{array}$ & $\begin{array}{l}\text { High construction cost } \\
\text { Large construction footprint } \\
\text { Significant potential for obstruction to fish } \\
\text { Potential for downstream channel degradation } \\
\text { due to trapping of sediment }\end{array}$ \\
\hline $\begin{array}{l}\text { Alternative construction } \\
\text { materials }\end{array}$ & $\begin{array}{l}\text { Economically feasible where stone is costly and } \\
\text { local labor force is inexpensive and available }\end{array}$ & $\begin{array}{l}\text { Often lack detailed design guidance } \\
\text { Increased monitoring and maintenance often } \\
\text { required }\end{array}$ \\
\hline
\end{tabular}

Table I.2.5 General grade stabilization techniques 


\section{APPENDIX I Goals, Objectives, Actions and Descriptions}

Objective 2.3: (580) Identify potential stream restoration project areas on protected private land and develop and implement plans to protect water quality

Action 2.3.1: Work with willing landowners to develop management goals, discuss and visit areas with known severely degraded riparian sites, stream bank erosion, debris or log jams that has resulted in the creation of a new channel, areas where the stream or drainage has been artificially straightened and channelized.

Action 2.3.2: (580) Implement stream bank and channel grade stabilizing techniques where appropriate. Many techniques are available to provide stream bank, channel and riparian stabilization. Projects should try to incorporate habitat functionality where feasible, minimize damage caused by construction, mitigate unavoidable damage and have a pre construction, during construction, and post construction monitoring of erosion, sensitive species and method effectiveness. Some of these techniques may require permits for construction. Consult regional NCRS office for more information before beginning a project. The methods below in Table I.2.6 are common tools used to reduce and prevent runoff, erosion and subsequent sedimentation. Selected methods in Table I.2.6 are further detailed in the figures and descriptions below. A number of sources provide further detail regarding techniques, construction details and illustrations. Some of these sources include: Environmentally-Sensitive Streambank Stabilization (ESenSS, Authored by Salix Applied Earthcare), the National Cooperative Highway Research Program, and the California Department of Fish and Game California Salmonid Stream and Habitat Restoration Manual (Alley et al. 2010). 


\section{APPENDIX I Goals, Objectives, Actions and Descriptions}

\begin{tabular}{|l|l|l|l|l|}
\hline \multicolumn{2}{|c|}{ Biotechnical Engineering } & Stream Corridor Habitat Improvement & River Training Stuctures & Structural Streambank Stabilization \\
\hline Brush Box & Live Fascine & Boulder Clusters & Bendway Weirs & Cobble or Gravel Armor \\
\hline Brushpacking & Live Gully Fill Repair & Meander Restoration & Cross Vanes & Geocellular Confinement System \\
\hline Coconut Fiber (Coir) Roll & Live Pole Drain & Newbury Rock Riffles & Longitudinal Stone Toe Protection & Live Cribwall \\
\hline Coconut Fiber (Coir) Mats & Live Siltation & Riitwad Revetnebt & Rock Vanes & Slope Flattening \\
\hline Compost Bermm & Live Staking & Vegetated Floodways & Rock Vanes with J-Hooks & Stepped or Terraced Slope \\
\hline Compost Blanket & Straw Anchoring & & Spur Dikes & Stream Diversion \\
\hline Erosion Control Blankets & Straw Rolls/Wattles & & Stone Weirs & Surface Roughening \\
\hline Geoberm Revetment & Trench Drain & & & Trench Fill Revetment \\
\hline Large Woody Debris Structures & Turf Enforcement Mats & & & Vegetated Articulated Concrete Blocks \\
\hline Live Brushlayering & Veg. Mech. Stabilized Earth & & & Vegetated Gabions \\
\hline Live Brush Mattress & Willow Posts and Poles & & & Vegetated Gabions Matress \\
\hline & & & & Vegetated Riprap \\
\hline
\end{tabular}

Source: Alley et al. (2010)

Table I.2.6 Instream and riparian restoration and erosion control techniques

Channel and slope erosion control blankets (ECBs) - are temporary erosion control devices that are made of natural or synthetic fiber. ECBs can be easily brought to the site, rolled out over the project area and secured down. Typical material consists of straw, wood, excelsior, coconut or a combination of these products. Material is then attached to or woven into synthetic or natural fiber netting. A number of biodegradable fibers are available depending on the durability and environmental sensitivity needs of the project. Figure I.2.8 below is an illustration of how erosion control blankets are utilized on a slope and stream channel. Figure I.2.9 outlines installation requirements of ECBs.

Figure I.2.8 Channel and slope erosion control blankets 


\section{APPENDIX I Goals, Objectives, Actions and Descriptions}

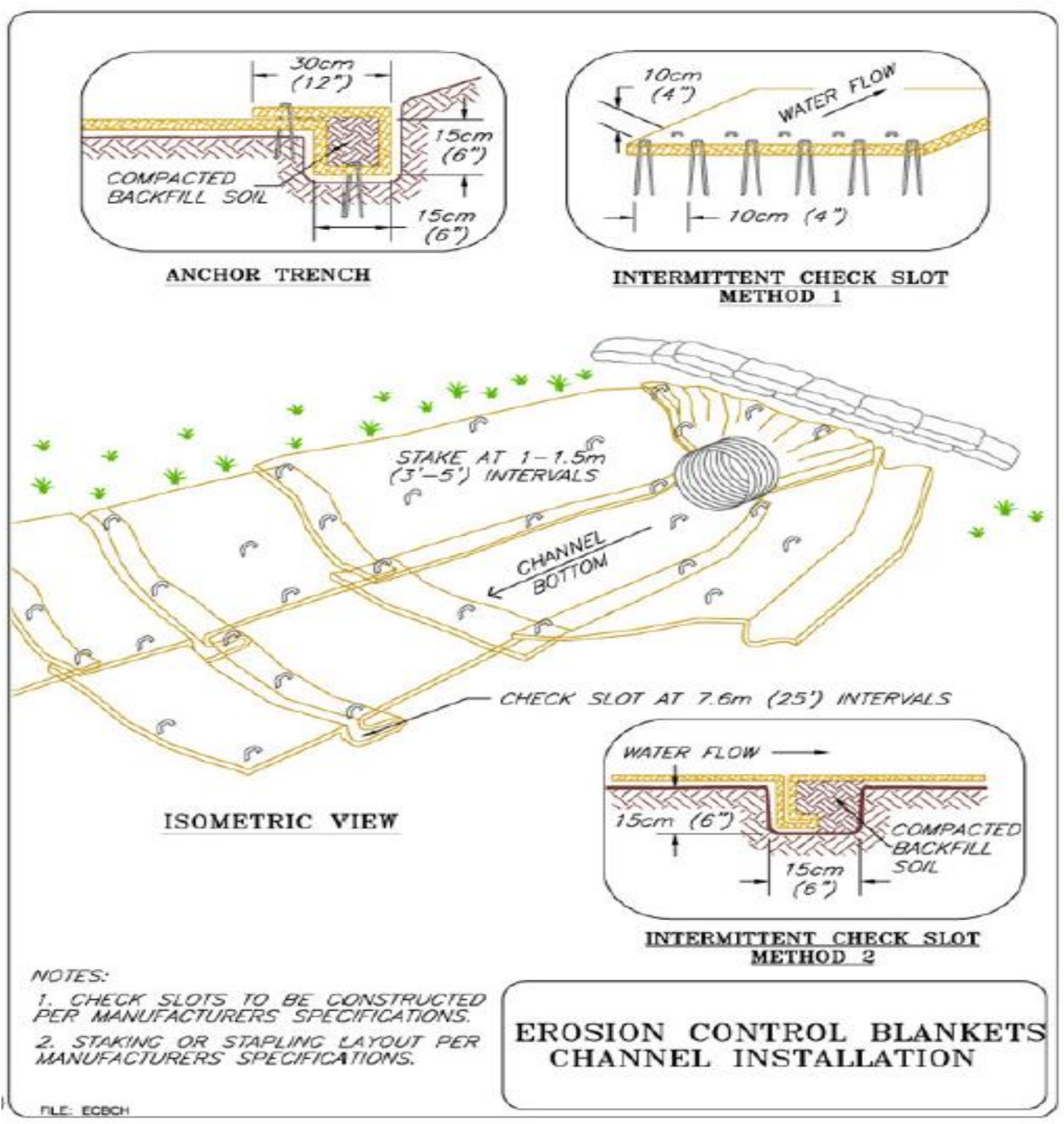

Source: Salix 2004

Figure I.2.9 Channel and slope erosion control blankets 


\section{APPENDIX I Goals, Objectives, Actions and Descriptions}

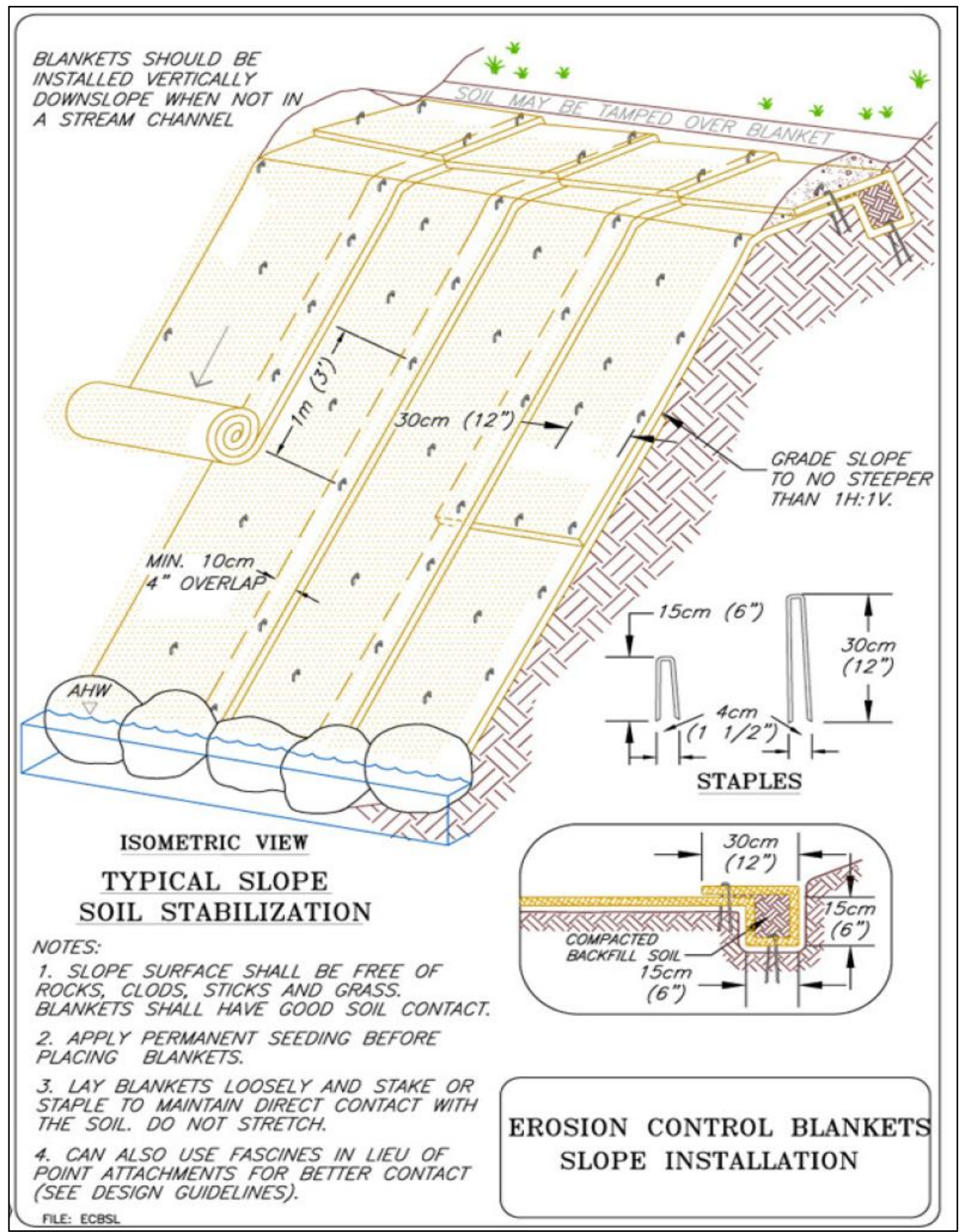

Source: Salix 2004 


\section{APPENDIX I Goals, Objectives, Actions and Descriptions}

Large Woody Debris Structures (LWD) - are engineered log jams made from felled trees. Their purpose is to direct erosion causing flows away from the channel bank and promote deposition at the base of eroding banks. The bottom section of the trunk and attached roots can be incorporated into the structures. Particular design of LWDs depend on the site and if done correctly can also provide aquatic habitat in addition to stream bank protection. Figure I.2.10 below is an illustration of a classic LWD design.

Figure 1.2.10 Design plan for Large Wood Debris

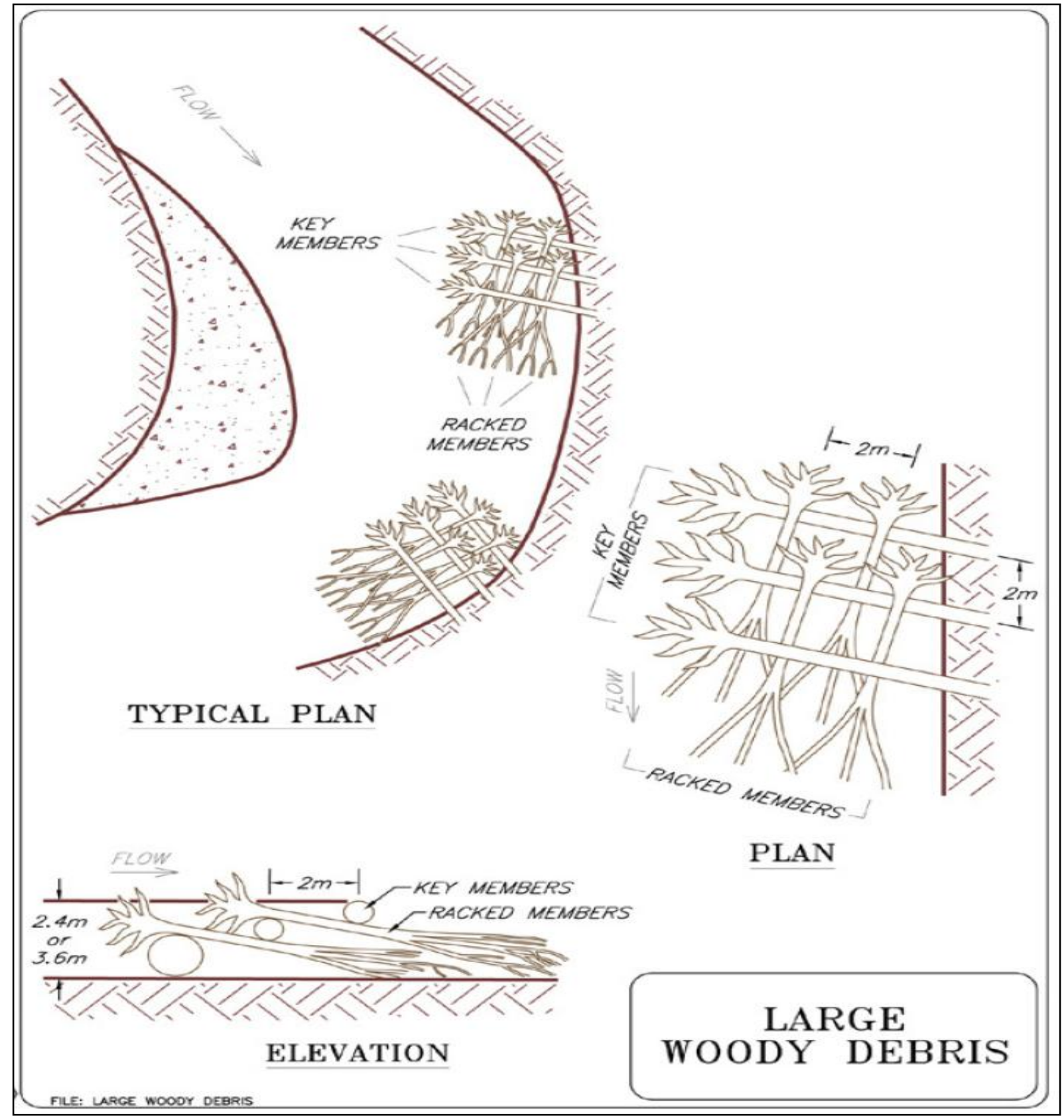

Source: John McCullah 2003 


\section{APPENDIX I Goals, Objectives, Actions and Descriptions}

Willow Posts and Poles - Provides mechanical streambank erosion protection by planting cut willow (Salix spp.) and cottonwood (Populus spp.) species, which are common riparian species and can establish roots and grow quickly along stream banks. This method is ideally used while vegetation is establishing along banks. Dense plantings of posts and poles can reduce flow velocity near the bank and provide reinforcement against shallow mass failures. This method are also ideal candidates for a combination with other structural methods such as Live Cribwalls, Cross Vanes and LWD structures. Figure I.2.11 illustrates the dimensions and use of willow and cottonwood posts and poles.

Figure I.2.11 Willow posts and poles

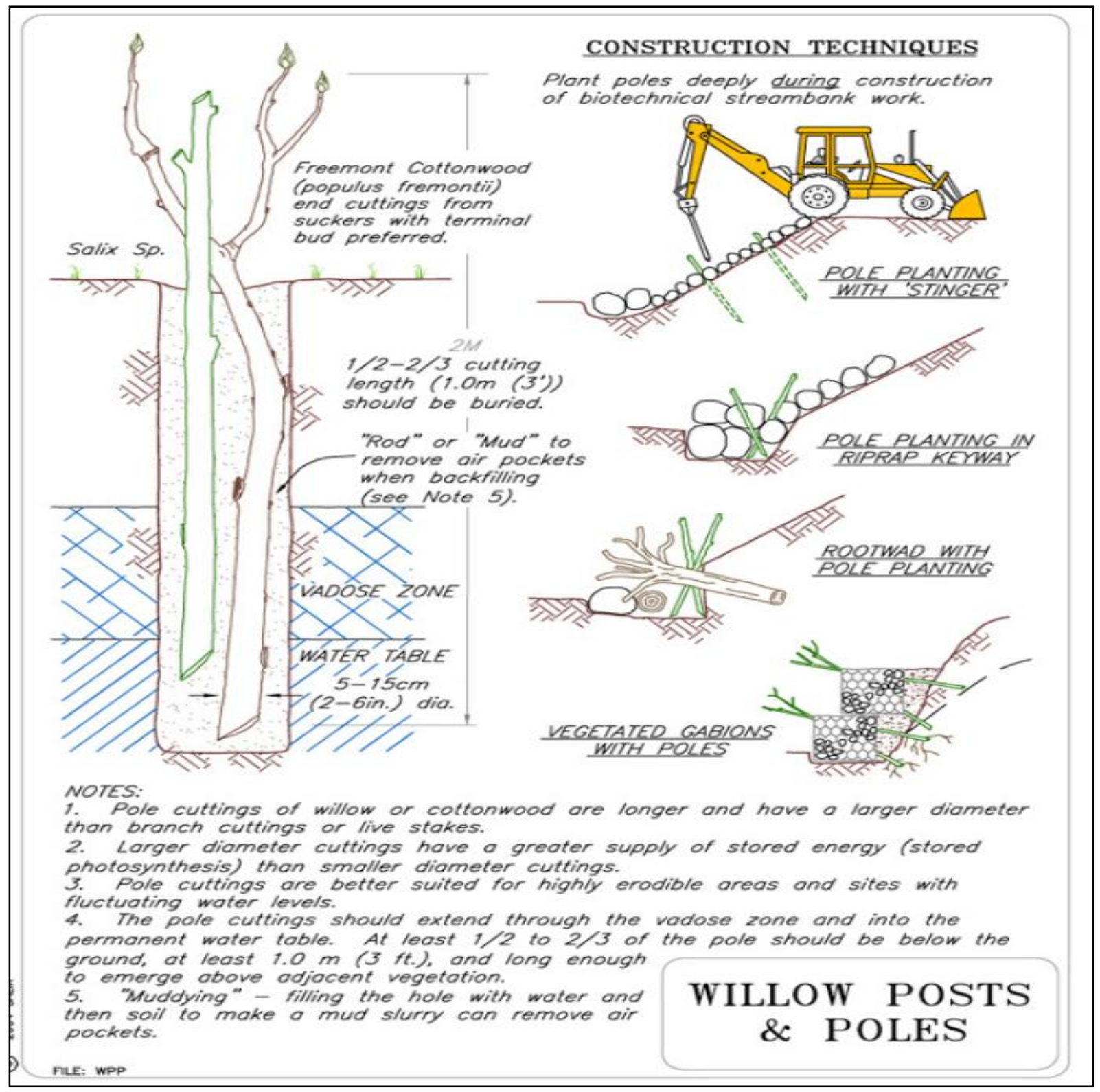

Source: Salix 2004 


\section{APPENDIX I Goals, Objectives, Actions and Descriptions}

Newbury Rock Riffles - ramps or low lying weirs made of riprap or small boulders. Riffles are constructed in intervals mimicking natural riffle spacing (5 to 7 channel widths). Rock is placed in an existing channel with the upstream rock being steeper than the downstream. This establishes a constructed longitudinal profile resembling that of natural riffles. These structures provide a habitat feature for aquatic wildlife, limited grade control and visual aesthetics. Figure I.2.12 illustrates the Newbury Rock Riffle design.

Figure I.2.12 Newbury rock riffles provide riffle habitat features and grade stabilization

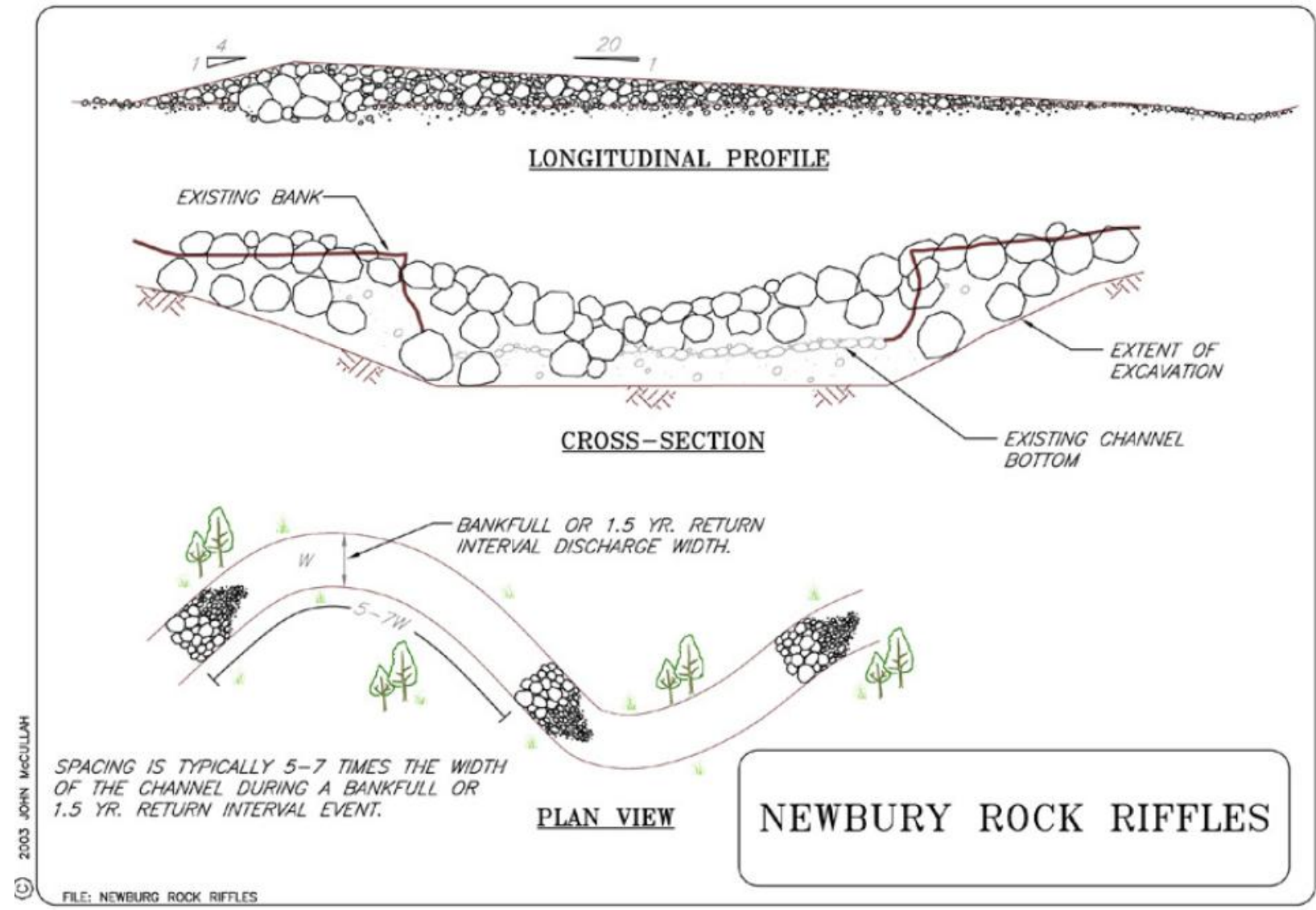

Source: John McCullah 2003 


\section{APPENDIX I Goals, Objectives, Actions and Descriptions}

Vegetated Floodway - floodways or constructed floodplain can provide flood protection with the construction of levees, floodwalls or by excavation on the other side of the floodway farthest from the channel. Establishing a broad floodway also dissipates flow energy during high water, allowing sediment to drop out in the floodway instead of being carried downstream. Vegetation in the floodway can also provide valuable wildlife habitat and/or recreational opportunities. Figure I.2.13 is a diagram of a vegetated floodway.

Figure I.2.13 Vegetated floodway

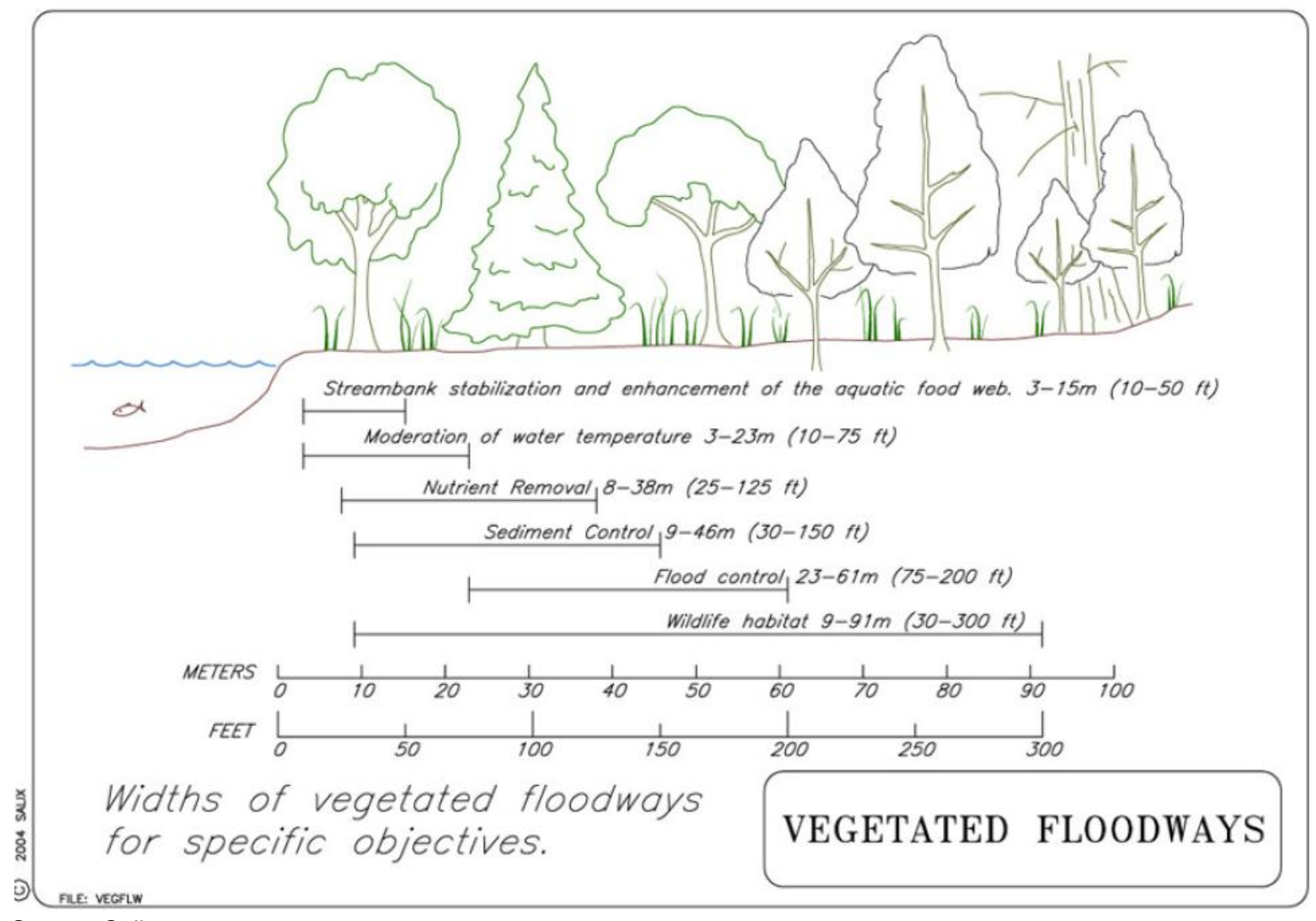

Source: Salix 2004 


\section{APPENDIX I Goals, Objectives, Actions and Descriptions}

Cross Vanes - Cross vanes redirect water way from stream banks into the center of the channel or thalwag. This takes stress off stream banks and provides habitat in the scour pools. Cross vanes modify flow patterns, add to substrate complexity and provide limited grade control. The device is made of rock structures that runs the width of the stream, is " $\mathrm{V}$ " shaped and points upstream. The lowest part of the structure is the endpoint of the "V" which is the furthest upstream. The crests have a three to five percent slope with the ends lodged into the stream banks at the approximate bankfull stage. Flows at all levels are supposed to overtop the structure. A double cross vane or "W" weir is a variation of the "V", but for wider channels. Figure I.2.14 is a diagram of a typical cross vane construction.

Figure I.2.14 Cross vane design

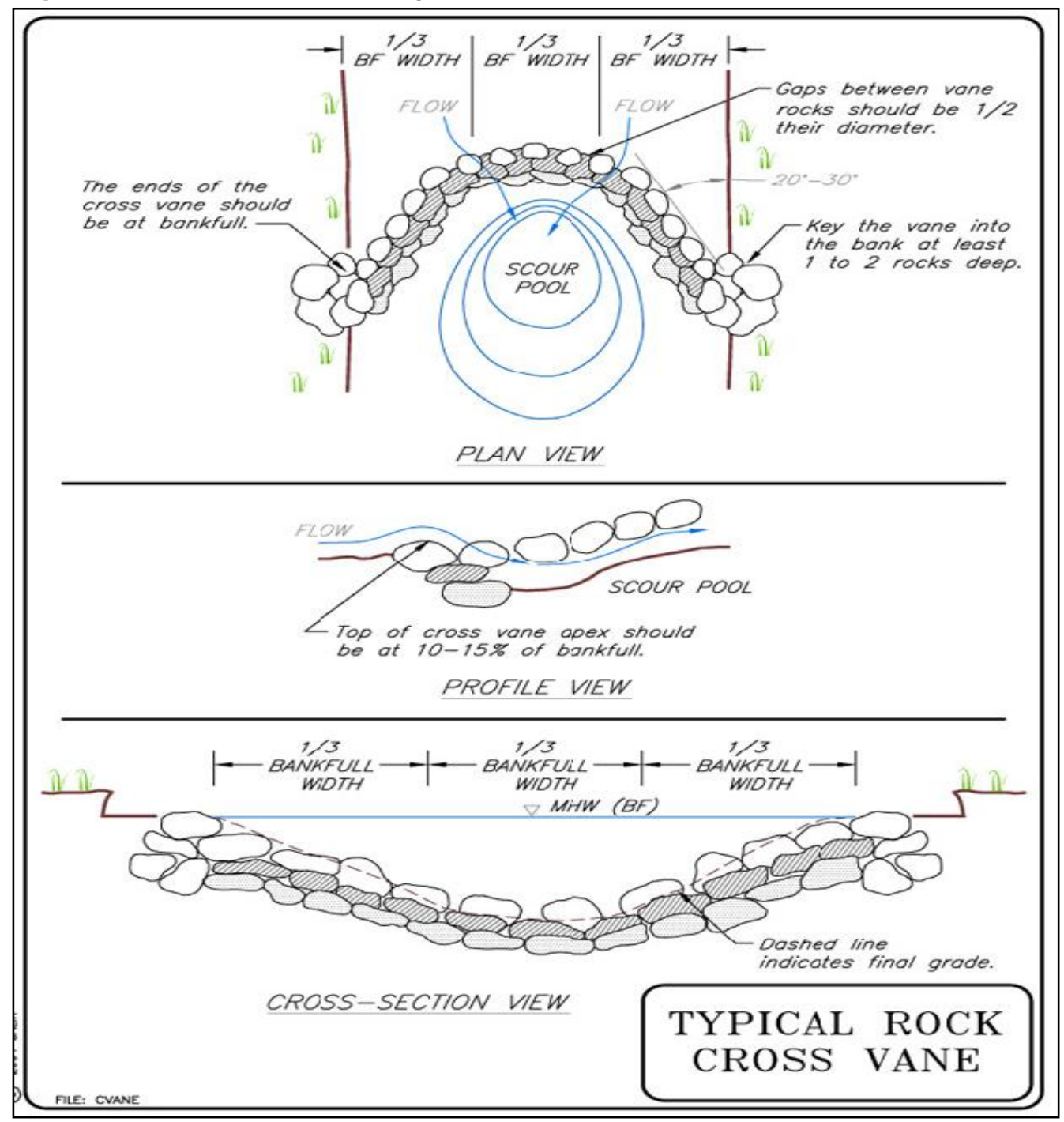

Source: Salix 2004 


\section{APPENDIX I Goals, Objectives, Actions and Descriptions}

Action 2.3.3: (322) Plant vegetation In areas lacking riparian vegetation, plant trees, shrubs and willow poles to provide habitat and channel bank stabilization. The NRCS handbook mainly discusses the use of woody vegetation to restore un-vegetated riparian areas, but the use of herbaceous vegetation is not necessarily counted. Site specific planning is an essential function of riparian restoration. This includes an understanding of flow rates, bank full depth, floodplain, channel morphology, etc. Success of planting vegetation depends on its ability to withstand the frequency and intensity of flooding and ability for roots to establish. Establishing vegetation objectives such as targeted wildlife usage, and plant species hardiness during fluctuating high and low water lines in the specific area need to be planned accordingly. Projects in partnerships between the Conservancy, agencies and landowners may warrant help from a hired crew or through a series of volunteer work days, depending on the willingness of the landowner and size of the project. Land managers and operators should consult an agency, consultant or experienced organization when planning these projects. Information on vegetation planting can be found in Action 3.2.6.

Action 2.3.4: (580) Where stream banks and in-stream morphology are damaged, in danger of being damaged and causing severe runoff and erosion problems and contributing to large inputs of sedimentation, plan and implement restoration and preventative enhancement techniques to provide channel stabilization. Restore modified or damaged streams using environmentallysensitive techniques to protect stream banks and infrastructure, reduce or repair erosion, establish riparian vegetation, and improve habitat for sensitive species. The techniques below can be used in combination or independently as warranted. It is strongly encouraged that agencies are consulted prior to any of the following practices being implemented, especially if part of a project has the potential to negatively impact a stream, river, lake, or wetland. Where feasible, restoration efforts should meet erosion and sedimentation reduction objectives while providing habitat for fish and wildlife. Examples of restoration tools and techniques are found in Table I.2.6.

Objective 2.4: Help landowners and organizations locate and utilize funding and technical resources including obtaining permits and grant money for in stream and stream bank restoration projects 


\section{APPENDIX I Goals, Objectives, Actions and Descriptions}

\section{Goal 3: Rangeland, ranching viability and the agricultural heritage associated with the region will be protected now and into the future}

Objective 3.1: The Conservancy shall work with landowners identified in the Upper Salinas Watershed Conservation Plan to establish long-term conservation to keep agricultural and rangeland in production.

Action 3.1.1: The Land Conservancy shall work with landowners who own large properties near already protected landscapes such as public and properties with existing conservation easements.

Action 3.1.2: The Land Conservancy shall initiate contact with landowners whose properties have been determined to be a priority for conservation to determine the appropriateness of developing partnerships for future conservation efforts.

Objective 3.2: Increase forage production and utilization by protecting existing soil and vegetation characteristics.

Action 3.2.1: (528a) Operation owners and managers should develop a prescribed grazing system that meets operational and ecosystem objectives. This may include establishing a network of cross fencing or paddocks and considers the frequency, intensity, stock density and timing of grazing depending on specific management objectives, temperature, precipitation and available vegetation. Consideration should be given to allowing forage species adequate rest to regenerate post grazing

- (590) Nutrient management through herd distribution forces cattle to utilize other areas to graze typically under-utilized areas while spreading nutrients through dung and urine along with an appropriate application of soil amendments.

- Seasonal timing i.e. allow rest for the regeneration of plant growth during the growing season 


\section{APPENDIX I Goals, Objectives, Actions and Descriptions}

- Minimize or prohibit grazing on wet, regenerating vegetation areas, compacted soil

- Encourage herd distribution to efficiently utilize available forage on rangeland while meeting RDM objectives

Action 3.2.2: (345) Operation owners and managers should manage for targeted levels of residual dry matter to promote regeneration of grassland forage vegetation. See Action 2.2.6 for more details.

Action 3.2.3: (484) Landowners and land managers should use mulch material such as straw, wood chips, etc to provide temporary upland erosion control, water retention, noxious weed control and generation of desirable plant species. See Action 2.2.7 for more details.

Action 3.2.4: (314) Land owners and land managers should develop and implement brush management using fire, grazing and/or manual methods can provide brush habitat for wildlife in some places, and removal of brush can also lead to increased forage production. See Action 1.3.5 for more details.

Action 3.2.5: $(342,327)$ Landowners and managers should identify highly erodible areas and implement a critical area planting program. This involves planting vegetation on highly erodible or critically eroding areas to reduce soil erosion and sediment delivery to surface waters. Vegetation can be permanent or temporary depending on management objectives. Permanent vegetation would provide benefits such as erosion reduction, improve water quality, provide wildlife habitat, enhance soil quality, and trap pests.

Action 3.2.6: $(550,512)$ Landowners and land managers should utilize reseeding techniques to improve rangeland habitat and forage production. Rangeland seeding of native species and nitrogen fixing legumes can increase forage production and fix nitrogen into the soil (University of California Davis 2011). Seeding can be expensive and failure is a possibility. Natural revegetation, used with a well managed grazing system can provide a more economical option. To improve the range condition, an assessment of the quantity and distribution of desirable plants should be made to determine the extent to which reseeding can be beneficial. In general, the following are steps that should be taken when considering reseeding: 


\section{APPENDIX I Goals, Objectives, Actions and Descriptions}

- Select an adequate site

- Select the proper species for seeding

- Prepare an adequate seedbed

- Plant during the proper time of year

- Plant the correct quantity of seed

- Allow for proper seed depth

- Allow plants to establish

- Utilize proper grazing management techniques

As a general rule, if desirable plants make up less than 10 to 15 percent of the total herbaceous vegetation, reseeding may be necessary. Any percentage over 15 percent, grazing management can be used to achieve herbaceous growth goals (UC Davis 2011). Seeding is often done with other types of land management tools, such as the use of prescribed fire and/or brush management particularly if the management tool is intensive that it removes or destroys the existing vegetation. Species composition is the most common reseeding objective.

Diverse composition can improve forage quality, livestock capacity, stabilize soil, improve water infiltration, reduce erosion and increase grassland habitat for wildlife. This can be done in combination with brush management techniques. In order to achieve forage production and land management goals, active forage production, including reseeding are important management tools.

Selection of sites to seeding should contain the highest potential for revegetation success. Sufficient soil depth is essential for root establishment and water retention or places that can be mechanically modified to increase soil depth. Rocky, barren, steep and potentially erosive sites should be avoided due to higher surface temperatures, erosive and runoff potential, and inability to hold moisture, which can all kill seedlings.

Selection of seed types is critical to the effectiveness of management goals. Seeds should be species that are adapted to the topography, soil and climatic conditions. The following are guidelines for seed selection (UC Davis 2011):

- Easy to establish

- Palatable to animals

- Relatively productive

- Able to withstand invasion by undesirable vegetation

- Able to withstand moderate grazing systems 


\section{APPENDIX I Goals, Objectives, Actions and Descriptions}

- Prevents erosion under moderate grazing systems

- Cost and availability

Native plants of the region are best adapted for the climate, soil, and topography. Determining the source of seeds is therefore an important part of seeding. It is recommended that operators and ranch managers should utilize certified named varieties when available. Both pure stands of individual species and a mixture of several species may be appropriate and can help stimulate species composition, mimics natural processes and increases the probability for success (Welch et al. 2011).

There are several recommendations for planting. First, seedbeds should be free from live vegetation competition and contain moderate quantities of plant residue or mulch on the soil to provide nutrients, help reduce competition and hold soil moisture. Plowing is the most common seedbed preparation method and there is a number of plowing methods depending on the type of vegetation and resource availability (Welch et al. 2011). Tilling practices increase the probability for erosion so consider minimal or no-till practices (UC Davis 2011). The most common seed dispersal methods are drilling (seeds placed directly into the soil and broadcasting (seeds dispersed on the surface of the soil). Broadcasting is the most common on rough rangeland areas and is most effective after the soil has been plowed/disturbed. Several methods for broadcast seeding include: by hand, rotary spreader, mechanical airstream or exhaust seed spreaders, and by aircraft. Aircraft is the most efficient over large areas, but can be costly (Welch et al. 2011).

Typical seeding rate is equivalent to twenty seeds per square foot, but vary slightly depending on the region. Seeding rates are measured in pounds of pure live seed (PLS) per acre. PLS expressed as a percentage and determined by multiplying the percent germination by percent purity of the seed variety. The number of seeds per pound varies with the species. The timing of planting seeds is important and is generally done in cooler temperatures and just before the rainy season. Seed depth is proportional to seed size. Smaller seeds should not be seeded as deeply as larger seeds. A general rule is to plant seeds four to seven times the diameter of the seed. When using multiple species mixtures, use the size of the smallest seed species used. Seeds are generally planted $1 / 4$ to $1 / 2$ inch but no deeper than $3 / 4$ of an inch (Welch et al. 2011).

Reseeded areas should be rested from grazing until plants can be established. Length of rest depends on the species being planted and the growing conditions. Poor conditions can require a resting period of 2 to 3 years. Weed control is also important during the reseeding 


\section{APPENDIX I Goals, Objectives, Actions and Descriptions}

stage. Mowing, shredding or herbicide application are tools available to keep noxious weeds from out competing desirable seed generation (Welch et al. 2011).

Action 3.2.7: (334) Landowners in partnership with restoration specialists and consultants should establish noxious weed management plans and implement plans to eradicate noxious weed growth and promote native plant species. Control noxious weeds to maintain existing native forage species diversity using a combination of fire management practices, controlled grazing or manual removal, chemical treatments and biological controls can be used depending on species reproductive and growth characteristics as well as management objectives. Table I.1.2 are examples of integrated strategies for reducing and preventing noxious weed invasion. It is recommended that treatments for noxious weeds are carefully planned to be catered to management objectives and effective. The difficulty of eradicating and maintaining minimal weed invasion often involves multiple types of treatments of several years depending on the species. Below are descriptions of the different types of treatments used to control noxious weeds.

- $\quad$ Prescribed burn - Backpack flaming devices are available on the market and burn the weeds providing a non-toxic weed controlling option. More detail can be found in the ATTRA publication "Flame Weeding for Agronomic Crops and Flame Weeding for Vegetable Crops."

- $\quad$ Chemical Treatments - Broad spectrum herbicide can control perennial weeds not eaten by livestock with careful and managed application. Hand-held sprayers can be effective, but wick-type applicators ensure chemical application directly on the targeted weed foliage. This type of applicator and equipment, designed to be pulled behind a tractor or four-wheeler are available.

- (548) Mechanical - Mechanical treatments such as mowing is expensive, particularly for landowners trying to deal with expansive areas of invasive species, but it can provide an effective method of dealing with invasive species by cutting them down before they flower and seed. This takes an understanding of a particular species reproductive cycle and growth habits (Beetz and Rhinehart 2010).

- (528a) Prescribed grazing - Specialized grazing practices can control non-native herbaceous and woody plant species. Livestock become less selective in their preferred forage due to the limited forage and space within a pasture. It is common for livestock to graze on young-tender noxious weeds that they normally reject as mature weeds (Beetz 


\section{APPENDIX I Goals, Objectives, Actions and Descriptions}

and Rhinehart 2010). Understanding noxious weed reproductive cycles, growth habits and relationship to desired plant species can facilitate appropriate timing and duration of livestock grazing to manage cattle in order to favor grazing on undesirable plant species (Paine and Ribic 2001). Utilizing multiple species grazing either by rotation or in tandem can also help control weeds as certain species of livestock will feed on different types of plants (Luginbuhl et al. 2000). For example, sheep have been used to control noxious rangeland weeds such as cheat grass. Sheep can supplement cattle in the pasture by consuming broadleaves, blossoms, and seeds. Goats are also used to control yellow star thistle and other herbaceous plant species (Pittroff, 2001).

- Biological treatments - there are also beneficial insects adapted to perennial pasture available commercially to control various types of perennial weeds. Local NRCS or ATTRA has information about biological management tools and where to get them (Beetz and Rhinehart 2010).

Action 3.2.8: (334) Landowners and managers should utilize prescribed burning methods in combination with other brush and invasive removal methods to setback succession, reduce brush and invasive species, and reduce competition for reseeding sites. The general rules of prescribed burning include:

- Fires can promote plant invasions

- Fire can be used as a tool to control plant invasions

- Plant invasions can affect fuels, fire behavior, and fire regimes

Fire can effectively control late season annual broadleaf and annual grass species, some species of Bromus as well as limited biennial broadleaves. Fire has been effective at controlling perennial grasses, bromes and certain woody species such as brooms (Cytisus spp) and Triadica sebifera (Masters and Shelley 2001). The effectiveness of fire is dependent upon reproductive characteristics of targeted species. Survival rates of these species are dependent upon the ability of reproductive tissue to withstand the high temperatures of fire. Plants with reproductive tissue underground (seeds and tubers) have higher survival and recovery rates than species with above ground tissue. General guidelines for fire treatment can be found in Brooks and Lusk (2008) United States Fish and Wildlife Service: Fire Management and Invasive Plants Handbook. Table I.3.1 shows some of the effects of fire on different plant communities 


\section{APPENDIX I Goals, Objectives, Actions and Descriptions}

\begin{tabular}{|lll|}
\hline Life Form (Raunkiaer type) & Regenerative tissue & $\begin{array}{l}\text { Exposure of regenerative tissue } \\
\text { to damage from fire }\end{array}$ \\
\hline Annual plants & $\begin{array}{l}\text { Seeds that reside on or under } \\
\text { the soil surface, or on dead } \\
\text { plants }\end{array}$ & $\begin{array}{l}\text { Depends on if seeds are } \\
\text { located above-ground on the } \\
\text { parent plant, or at or below } \\
\text { the soil surface after they have } \\
\text { dispersed from the parent plant. }\end{array}$ \\
\hline Bulbs or corms & $\begin{array}{l}\text { Living tissue well below the soil } \\
\text { surface }\end{array}$ & $\begin{array}{l}\text { Protected from fire due to soil } \\
\text { insulation above them. }\end{array}$ \\
\hline Rhizomatous plants & $\begin{array}{l}\text { Living tissue just above or } \\
\text { below the soil surface }\end{array}$ & $\begin{array}{l}\text { Depends on the percentage of } \\
\text { litter burned and the amount of } \\
\text { smoldering combustion. }\end{array}$ \\
\hline Shrubs & $\begin{array}{l}\text { Living tissue just above the soil } \\
\text { surface }\end{array}$ & $\begin{array}{l}\text { Non-fire-adapted shrubs can } \\
\text { be killed by fire due to their } \\
\text { positioning directly in the flame } \\
\text { zone of surface fires. }\end{array}$ \\
\hline Trees & $\begin{array}{l}\text { Living tissue well above the soil } \\
\text { surface }\end{array}$ & $\begin{array}{l}\text { Can be killed by crown fire } \\
\text { that passes though the plant } \\
\text { canopies, or by surface fire that } \\
\text { girdles the trees. }\end{array}$ \\
\hline
\end{tabular}

Source: Brooks and Lusk 2008 and Pyke et al 2002.

Table I.3.1 Effects of fire on different plant life forms

Action 3.2.9: Operation owners and managers should develop a forage monitoring program to monitor RDM, forage rates and climatic conditions, soil quality, etc based land management objectives and baseline data. Forage monitoring provides a pragmatic approach to meeting objectives. Implementing land management actions and monitoring them for the success and failures and making changes to management techniques can provide a methodical approach to implementing a sustainable land management program. Monitoring the amount of residual dry matter, soil quality, condition of existing forage, dung assessments and cattle health are all indicators of the conditions of the quantity and quality of forage vegetation on the rangeland. $A$ scorecard was developed by McDougald et al. (1991) that estimates the grazing capacity of an area based on a set of site characteristics that include: rainfall, canopy cover, and slope. These characteristics affect livestock use of the land and help to calculate carrying capacity. This method is proven to be a useful tool particularly if it is coupled with the use of geographic information systems to map forage availability (Standiford et al. 1999).

The location of the Conservation Area being relatively near the Pacific Coast and between two mountain ranges creates variable climatic conditions. To categorize the guidelines for residual dry matter management on California grasslands and in oak hardwood savannahs, there are three classifications:

- Dry annual grassland - Dominated by annual plant species with an average rainfall of less than 12 inches. 


\section{APPENDIX I Goals, Objectives, Actions and Descriptions}

- Annual grassland/hardwood range - Presence of a variable shrub or oak canopy with annual vegetation understory. Average rainfall is between twelve and forty inches.

- Coastal prairie - Variable woody canopy with the common understory being Perennial grasses. Rainfall is highly variable.

A good resource on RDM assessment methods and more detailed information on RDM guidelines, the University of California Division of Agriculture and Natural Resources publication, "California Guidelines for Residual Dry Matter (RDM) Management on Coastal and Foothill Annual Rangelands" by Bartolome et al (2002).

Objective 3.3: Utilize sustainable farming practices to produce healthy crops, reduce/minimize erosion and protect water supply and quality

Action 3.3.1: Operation owners and managers should implement structural practices for crops where appropriate. This includes constructing or otherwise implementing projects that reduce pollution into nearby waterways. Examples of structures include silt fencing, permanent vegetation used for wind erosion and contour farming and terrace construction on hillsides that break up the slope.

Action 3.3.2: (329) Operation owners and managers should implement conservation tillage practices. Grow crops with the minimum amount of tillage necessary to manage pests and reduce compaction. Reduction of tillage depth and the conservation of plant residue protect the soil surface from erosion; improve soil health, quality, and structure; and increases infiltration. Conservation tillage is often coupled with a plant residue management system. Conservation tillage are strategies and techniques for growing crops, and establishing rangeland seed using previous crop residue (Sullivan 2003). The purpose is to reduce soil erosion, improved water conservation, reduce fuel consumption, reduce compaction, extend planting and harvesting flexibility and improve soil tilth. Common conservation tillage practices include:

- Ridge till utilized specialized planters and cultivators to establish permanent ridges where crops are grown. Post-harvest, crop residue is left until the next planting cycle. Once seeds are ready to be planted, plant residue is pushed aside and planters place the seed in the top of the ridge. At this point, the surface of the ridge is sliced off and are reformed at the last cultivation of that planting cycle. Herbicides are banded during 


\section{APPENDIX I Goals, Objectives, Actions and Descriptions}

planting and two cultivations are generally used during this process: One to loosen the soil and the other to establish the ridge. Under this tillage practice, the use of herbicides is reduced compared to conventional or no-till practices. According to Preston Sullivan (2003), "Maintenance of the ridges is critical to a successful ridge tillage system. The equipment must accurately reshape the ridge, clean away crop residue, plant in the ridge center, and leave a viable seedbed."

- No-till practices do not use tillage to establish seedbeds. Crops are planted into plant residue from previous year's harvest. Herbicides are typically the only form of weed control and as a result has received criticized for their reliance on chemical treatments. Costs associated with the practice can be expensive primarily for the appropriate machinery. No-till is great at erosion control and requires minimal trips. A functioning system generally takes several years to function probably and may require adaptive management (Sullivan 2003).

Action 3.3.3: (328) Operation owners and managers should apply crop rotation practices where appropriate. Crop rotation is an important tool used to control weeds and pests, cycle nutrients, and maintain/establish desirable soil quality. There are many methods to crop rotation, which largely depend on the type of crops being grown and the desired outcomes of the crop rotation system. The basic premise is to have a number of different crops planted in designated areas on the same field. Those different crops are rotated to different areas annually or every couple of years depending on the system being used. This allows different nutrients to be inputted and utilized by different crops, which have different nutritional needs. It also prevents the spread of pests who may rely on one crop for reproduction and food. The regional NRCS and University of California Extension Services can help determine an appropriate crop rotation system for your crops.

Action 3.3.4: (340) Operation owners and managers should utilize cover crops where appropriate. The use of cover crops is frequently used to control pests, weeds, erosion, help establish or maintain desired nutrient balances, and/or retain soil moisture. Potential costs and benefits of using cover crops are outlined in Table 1.3.2. The use of cover crops depends on a number of factors including: 


\section{APPENDIX I Goals, Objectives, Actions and Descriptions}

- Specific growing objectives of the cover crop (soil quality improvement, input of organic matter, maintain residual nitrogen, preventing nitrate leaching, inputting or scavenging other nutrients, or controlling weeds and pests

- Timing of planting and any changes in current crop management as a result

- Investments in the capital, such as equipment, that may increase costs in comparison to overall product yield.

- Soil, water and nutrient needs for cultivated/harvested crops (non cover crops). Different crops have different needs, inputting and exporting different nutrients from the soil. Particular cover crops can counter balance those processes by adding or subtracting nutrients from the soil that plants need or don't need.

The use of specific cover crops is dependent on site-specific conditions. Test plots should be used initially to determine the most appropriate cover cropping system before expanding it to the entire crop system. Understanding cover crop types and the risks and benefits associated with them along with proper cover crop management can increase the success of use. Monocultures of cover crops are commonly used in California, but can create problems with soil quality, pests and nutrient cycling if the same cover crop is utilized every year. It is recommended that a mix of species be utilized.

More information on mixing suggestions for cover crop systems used for orchards and vineyards can be found by reading Chuck Ingles, "Cover Crop Selection and Management in Orchards and Vineyards." Sustainable Agriculture Research and Education Program, UC Davis. At http://www.sarep.ucdavis.edu/ccrop/CCPubs/CCSelectionAndManagement.html

\section{Management Considerations}

- $\quad$ Planting - Winter annual and perennial crops are best grown when planted in midOctober through mid-November. Establishing small seeded cover crops can be difficult in years with little rainfall. As a general rule, seeding earlier in the year requires less seed than in later parts of the year. Seedbed preparation is essential particularly with the use of native grasses. Legume seeds should be supplemented with nitrogen-fixing bacteria where seeds are not preinoculated.

- $\quad$ Mowing - The timing and height at which cover crops should be mowed depends on the cover crop species. Mowing can reduce performance or even kill some species, so 


\section{APPENDIX I Goals, Objectives, Actions and Descriptions}

knowing what your management objective are and the requirements of your cover crops is essential.

- Nutrition - Legumes fix nitrogen and do not need inputs of nitrogen before or during growth, but do require sulfur, which is abundant in most vineyards) and phosphorus. In general, both perennial and annual grasses grow well on highly fertile sites and may need inputs of nitrogen to flourish. Legumes grow best in soils containing low levels of nitrogen. Legumes grown in high nitrogen soils maybe overtaken by grasses and mustards. Some legumes such as vetches and pea fix more nitrogen than clover and medics. Excessive nitrogen in the soil may increase plant vigor in vineyards. One example consideration for addressing this issue includes alternate row planting of cover crops. An example is to plant perennial grasses in alternating rows and mow the grass instead of disking the area. Mowed plant material left on the surface of the soil produces volatilized nitrogen that is released into the atmosphere instead of as useable nitrogen in the soil.

\begin{tabular}{|l|l|}
\hline Potential Benefits of Cover Crops & Potential Problems with Cover Crops \\
\hline Addition or conservation of nitrogen & $\begin{array}{l}\text { Increased costs and management, but benefits may } \\
\text { outweigh costs }\end{array}$ \\
\hline Reduced soil erosion & Depletion of soil moisture \\
\hline Addition of organic matter to soil & Increased frost hazard \\
\hline Weed suppression & Increases weed problems \\
\hline Improved soil structure and water pen. & Increased pests \\
\hline Improved traction & \\
\hline Increased beneficial arthropods & \\
\hline
\end{tabular}

Source: Ingles

Table I.3.2 Potential costs and benefits of cover cropping

Action 3.3.5: Landowners and land managers should establish narrow bands of permanent vegetation on hill slopes that are farmed on the contour, to reduce sheet and rill erosion, reduce sediment and other water-borne contaminants transport, and increase infiltration. Cultivated strip widths are determined by a number of factors including: slope variability, climate, erosion 


\section{APPENDIX I Goals, Objectives, Actions and Descriptions}

potential and specific field conditions. Buffer vegetation depends on soil types and climate. A report by Rein et al. (1998) studied and reviewed the effectiveness of perennial grasses as a contour buffer near Elkhorn Slough. Results indicated that annual grasses are most effective at managing non-point source pollution in the first year after planting, followed by perennial effectiveness in the second and third years.

Action 3.3.6: Operation owners and managers should utilize standards developed by the California Sustainable Winegrowing Alliance 's Best management practices in the Code of Sustainable Winegrowing Practices Self-Assessment Workbook found at http://www.sustainablewinegrowing.org/swpworkbook.php. And the Central Coast Vineyard Team's Sustainability in Practice Standards, which can be found at http://www.vineyardteam.org/sip/standards-and-rules.php to implement industry standards that are economically and ecologically sound.

Action 3.3.7: Operation owners and managers should implement an irrigation system where all necessary equipment and facilities are installed for efficiently and uniformly applying irrigation to maintain soil moisture at the necessary level to grow crops without causing excessive water loss, erosion, or water quality impairment. While much of the grain and hay production in the Conservation Area is dry farming, the production of wine grapes does necessitate irrigation. Much of the industry currently uses drip irrigation systems. Drip irrigation or "micro irrigation" systems are one of the most efficient irrigation systems and are common practice in vineyards. It allows for the slow input of water into the soil, which reduces evaporation and allowing for the plants to utilize more of the available water. Water is also applied directly to where it is needed. Drip emitters are located near the crops needing water, as oppose to a sprinkler system that spreads water across a certain radius of the field whether there are crops there or not. Figure I.3.1 illustrates a basic drip irrigation system design. Drip irrigation design efficiency is about placement of emitters (i.e. under shaded cover where possible near the plant to prevent evaporation and to ensure that the root system gets the water) and checking for and fixing leaks. Some commercial irrigators use "hard pipe" irrigation where PVC lines are buried underground and emitters are placed in the root zone (2 to 10 inches deep) (California Agricultural Stewardship Initiative).

To increase water efficiency it is recommended that "smart controllers" or evapotranspiration (ET) controllers be installed. The Irrigation Association (www.irrigation.org) 


\section{APPENDIX I Goals, Objectives, Actions and Descriptions}

defines "smart controllers" as controllers that reduce outdoor water use by monitoring and using information about site conditions such as soil moisture, rain, wind, slope, soil, plant type, and more), and applying the right amount of water based on those factors.

Figure I.3.1 Basic drip irrigation system

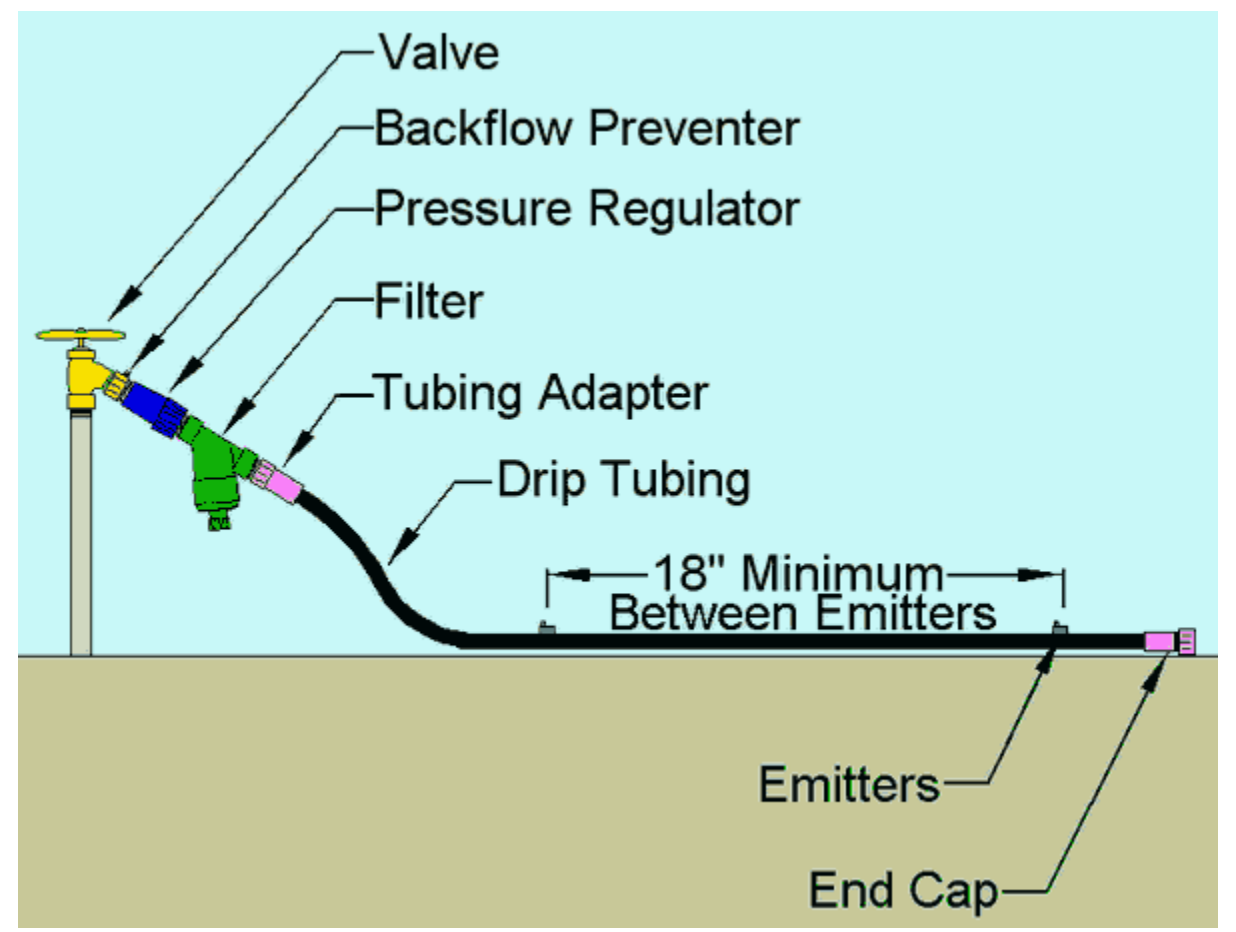

Source: www.irrigationtutorials.com

Action 3.3.8: Operation owners and managers should develop water conveyance structures or systems to prevent waterlogging of soil, maintain water quality, and reduce water loss where appropriate.

Objective 3.4: Continue to learn about sustainable management techniques, where to find financial and technical resources and share success and innovative management practices and projects with the broader ranching, scientific and environmental community.

Action 3.4.1: Operation owners, managers as well as organizational and agency personnel should attend UC Extension Service rangeland management workshops, NRCS rangeland management workshops, California Rangeland Conservation Coalition meetings and any other agricultural producer or land management workshop where land management ideas and 


\section{APPENDIX I Goals, Objectives, Actions and Descriptions}

innovative concepts are discussed. Landowners, operators, managers, local non-profits and agency personnel can learn what others are doing in the agricultural, scientific and political arena that can help increase agricultural and livestock profit margins through the nexus of shared knowledge regarding innovative land management techniques. These venues can also help establish contacts and potential partnerships for conservation and land management projects in the future.

\section{Goal 4: Urban areas will protect ecological resources including water quality and quantity}

Objective 4.1: New and existing urban development will be renovated or constructed in ways that protect ecological resources including wildlife habitat.

Action 4.1.1: Local government should implement the development and maintenance standards for water body protection as described in the California Stormwater Quality Association's (CASQA) Stormwater Best Management Practice (BMP) Municipal Handbook (2004) as outlined in Table I.4.1. The National Pollutant Discharge Elimination System (NPDES) has specific requirements for construction projects. Project sponsors with projects undergoing construction resulting in one or more acres of soil disturbance potentially generating polluted stormwater are subject to these standards. Some of which are listed below. 


\section{APPENDIX I Goals, Objectives, Actions and Descriptions}

\begin{tabular}{|c|c|}
\hline Source Control BMPs & Source Control BMPs \\
\hline SC-10 Non-Stormwater Discharges & $\begin{array}{l}\text { SC-43 Parking/Storage Area } \\
\text { Maintenance }\end{array}$ \\
\hline $\begin{array}{l}\text { SC-11 Spill Prevention, Control \& } \\
\text { Cleanup }\end{array}$ & SC-50 Over Water Activities \\
\hline SC-20 Vehicle and Equipment Fueling & SC-60 Housekeeping Practices \\
\hline SC-21 Vehicle and Equipment Cleaning & SC-61 Safer Alternative Products \\
\hline SC-22 Vehicle and Equipment Repair & SC-70 Road and Street Maintenance \\
\hline SC-30 Outdoor Loading/Unloading & SC-71 Plaza and Sidewalk Cleaning \\
\hline SC-31 Outdoor Container Storage & SC-72 Fountain \& Pool Maintenance \\
\hline SC-32 Outdoor Equipment Maintenance & SC-73 Landscape Maintenance \\
\hline SC-33 Outdoor Storage of Raw Materials & SC-74 Drainage System Maintenance \\
\hline SC-34 Waste Handling \& Disposal & SC-75 Waste Handling and Disposal \\
\hline SC-41 Building \& Grounds Maintenance & SC-76 Water \& Sewer Utility Maint. \\
\hline Treatment Control BMPs & Treatment Control BMPs \\
\hline TC-10 Infiltration Trench & TC-30 Vegetated Swale \\
\hline TC-11 Infiltration Basin & TC-31 Vegetated Buffer Strip \\
\hline TC-12 Retention/Irrigation & TC-32 Bioretention \\
\hline TC-20 Wet Pond & TC-40 Media Filter \\
\hline TC-22 Extended Detention Basin & TC-50 Water Quality Inlet \\
\hline
\end{tabular}

Source: CASQA Stormwater Best Management Practice (BMP) Handbooks - Municipal Handbook 2004.

Table I.4.1 Best Management Practices used to reduce impacts to water bodies in urban areas.

Action 4.1.2: Local governments, landowners establishing access roads, and transportation authorities should implement the guidelines and standards described in Caltrans Storm Water Quality Construction Site Best Management Practices Manual (2003) and outlined in Table I.4.2 The National Pollutant Discharge Elimination System (NPDES) has specific requirements for 


\section{APPENDIX I Goals, Objectives, Actions and Descriptions}

construction projects. Project sponsors with projects undergoing construction resulting in one or more acres of soil disturbance potentially generating polluted stormwater are subject to these standards. Some of which are listed below.

\begin{tabular}{|c|c|}
\hline Temporary Soil Stabilization & Non-Storm Water Management \\
\hline SS-1 Scheduling & NS-1 Water Conservation Practices \\
\hline SS-2 Preservation of Existing Vegetation & NS-2 Dewatering Operations \\
\hline SS-3 Hydraulic Mulch & NS-3 Paving and Grinding Operations \\
\hline SS-4 Hydroseeding & NS-4 Temporary Stream Crossing \\
\hline SS-5 Soil Binders & NS-5 Clear Water Diversion \\
\hline SS-6 Straw Mulch & NS-6 Illicit Connection/Illegal Discharge \\
\hline $\begin{array}{l}\text { SS-7 Geotextiles, Plastic Covers \& Erosion Control } \\
\text { Blankets }\end{array}$ & NS-7 Potable Water/Irrigation \\
\hline SS-8 Wood Mulching & NS-8 Vehicle and Equipment Cleaning \\
\hline SS-9 Earth Dikes/Drainage Swales \& Lined Ditches & NS-9 Vehicle and Equipment Fueling \\
\hline SS-10 Outlet Protection/Velocity Dissipation Devices & NS-10 Vehicle and Equipment Maintenance \\
\hline SS-11 Slope Drains & NS-11 Pile Driving Operations \\
\hline SS-12 Streambank Stabilization & NS-12 Concrete Curing \\
\hline Temporary Sediment Control & NS-13 Material and Equipment Use Over Water \\
\hline SC-1 Silt Fence & NS-14 Concrete Finishing \\
\hline SC-2 Sediment/Desilting Basin & $\begin{array}{l}\text { NS-15 Structure Demolition/Removal Over/Adjacent to } \\
\text { Water }\end{array}$ \\
\hline SC-3 Sediment Trap & Waste Management and Materials Pollution Control \\
\hline SC-4 Check Dam & WM-1 Material Delivery and Storage \\
\hline SC-5 Fiber Rolls & WM-2 Material Use \\
\hline SC-6 Gravel Bag Berm & WM-3 Stockpile Management \\
\hline SC-7 Street Sweeping and Vacuuming & WM-4 Spill Prevention and Control \\
\hline SC-8 Sandbag Barrier & WM-5 Solid Waste Management \\
\hline SC-9 Straw Bale Barrier & WM-6 Hazardous Waste Management \\
\hline SC-10 Storm Drain Inlet Protection & WM-7 Contaminated Soil Management \\
\hline Wind Erosion Control & WM-8 Concrete Waste Management \\
\hline WE-1 Wind Erosion Control & WM-9 Sanitary/Septic Waste Management \\
\hline Tracking Control & WM-10 Liquid Waste Management \\
\hline \multicolumn{2}{|l|}{ TC-1 Stabilized Construction Entrance/Exit } \\
\hline \multicolumn{2}{|l|}{ TC-2 Stabilized Construction Roadway } \\
\hline TC-3 Entrance/Outlet Tire Wash & \\
\hline
\end{tabular}

Source: Caltrans Storm Water Quality Handbooks, Construction Site Best Management Practices Manual, March 1, 2003.

Table I.4.2 Management measures and practices used to protect sensitive habitats during construction projects. 


\section{APPENDIX I Goals, Objectives, Actions and Descriptions}

\section{Literature Cited}

Alley, D., S. Smith, K. Dettman, B. Hill, M. LeBrun, B. Stark. (2010). Santa Rosa Creek Watershed Conservation Plan. Land Conservancy of San Luis Obispo County.

Anderson, P.R. 1968. The reproductive and developmental history of the California tiger salamander. Master's Thesis, Department of Biology, Fresno State College, Fresno, CA.

Barry, S.J. and H.B. Shaffer. 1994. The status of the California tiger salamander (Ambystoma californiense) at Lagunita: a 50-year update. Journal of Herpetology 28:159-164.

Bartolome, James W.; Frost, William E.; McDougald, Neil K.; Connor, Michael. (2002). California Guidelines for Residual Dry Matter (RDM) Management on Coastal and Foothill Annual Rangelands. University of California Division of Agriculture and Natural Resources. Publication 8092.

Beetz, A. E., L. Rinehart. (2010). Rotational Grazing. National Sustainable Agricultural Information Service. National Center for Appropriate Technology.

Bellows, B. C. (2003). Protecting riparian areas: Farmland management strategies. Soil systems guide, appropriate technology transfer for rural areas. At www.attra.ncat.org.

Berton, V. (1998). Ten Years of SARE. Sustainable Agriculture Research and Education Program, CSREES, U.S. Department of Agriculture. Washington, DC. p. 82-83.

Bovey, R.W. (1995). Weed management systems for rangelands. p. 519-552. In: A.E. Smith (ed.), Handbook of weed management systems. Marcel Dekker, Inc. New York, N.Y.

Brooks, M. and M. Lusk (2008) Fire Management and Invasive Plants Handbook. United States Fish and Wildlife Service.

Brunson, M.W., and L. Huntsinger. (2008). Ranching as a conservation strategy: Can old ranchers save the New West? Rangeland Ecology and Management 61:137-147.

Bulger, J. B., N. J. Scott, Jr., and R. B. Seymour. 2003. Terrestrial activity and conservation of adult California red-legged frogs Rana aurora draytonii in coastal forests and grasslands. Biological Conservation 110:85-95.

California Agricultural Stewardship Initiative. Website: http://agwaterstewards.org/txp/Home/. Accessed on June 1, 2011.

California Department of Forestry and Fire Protection. (2010). http://frap.fire.ca.gov/assessment2010.html California's Forests and Rangelands 2010 Assessment. Fire and Resource Protection Program.

Caltrans. (2003). Sediment/Desilting Basin. Caltrans Storm Water Quality Handbooks. Construction Site Best Management Practices Manual. 


\section{APPENDIX I Goals, Objectives, Actions and Descriptions}

Clark Conservation District. Pasture Systems and Grazing Methods. Pasture Management Guide for Livestock Producers, lowa State University Extension. Washington.

Derscheid, L.A., L.J. Wrage, and W.E. Arnold. 1985. Cultural control of leafy spurge,. p. 57-64. In: A.K. Watson (ed.), Leafy spurge. Monogr. No. 3, Weed Sci. Soc. Amer., Champaign, III.Vallentine 1989

Devine, M., S.O. Duke, and C. Fedtke. (1993). Physiology of herbicide action. Prentice Hall, Englewood Cliffs, N.J.

Drake, D.J. Monitoring Residual Dry Matter. University of California Extension Services. UC Davis Extension Services Website, http://animalscience.ucdavis.edu/extension/Factsheets/RangelandResources/

Feaver, P.E. 1971. Breeding pool selection and larval mortality of three California amphibians: Ambystoma tigrinum californiense Gray, Hyla regilla Baird and Girard and Scaphiopus hammondi hammondi Girard. Master's Thesis, Department of Biology, Fresno State College, Fresno, California. 58 pp.

Frost, R.A. and K.L. Launghbaugh (2003). Prescription Grazing for Rangeland Weed Management: A New Look at an Old Tool. Rangelands Vol 25 (6) p 43-47.

Fellers, G. M. and P. M. Kleeman. 2007. California red-legged frog (Rana draytonii) movement and habitat use: implications for conservation. Journal of Herpetology. 41(2): 271-281.

Food and Agricultural Organisation of the United Nations (2011). Surface water resources development for rangeland. Website:

http://www.fao.org/docrep/R7488E/r7488e06.htm\#5.1 surface water utilization and development

Gerrish, J.R., P.R. Peterson, and R. E. Morrow. Distance Cattle Travel to Water Affects Pasture Utilization Rate. Forage Systems Research Center. Missouri University. http://aes.missouri.edu/fsrc/research/afgc95h2.stm

Goard, D. (August 2006). Riparian Forest Best Management Practices: Fencing. Kansas State University.

Hart, R.H., M.J. Samuel, J.W. Waggoner, and M.A. Smith. 1989. Journal of Soil and Water Conservation.

Herrick, J. E., J. R. Brown, A. J. Tugel. P. L. Shaver, and K. M. Havstad. (2002). Applications of soil quality to monitoring and management: Paradigms from rangeland ecology. Agronomy Journal. V. 94. p. 3-11.

Indiana Division of Fish and Wildlife. (2004). Natural Revegetation. Fact Sheet. Indiana Department of Natural Resources. 


\section{APPENDIX I Goals, Objectives, Actions and Descriptions}

Ingles, C. Cover Crop Selection and Management in Orchards and Vineyards. Sustainable Agriculture Research and Education Program, UC Davis. http://www.sarep.ucdavis.edu/ccrop/CCPubs/CCSelectionAndManagement.html

Jennings, M.R. and M.P. Hayes. 1994. Amphibian and reptile subspecies of special concern in California. California Department of Fish and Game, Inland Fisheries Division, Rancho Cordova, California. iii+255 pp.

Keller, G., and J. Sherar. (2003). Low volume road engineering: Best Management Practices Field Guide. USDA Forest Service/ USAID. National Transportation Library Website, http://ntl.bts.gov/lib/24000/24600/24650/Index BMP Field Guide.htm

Kocher, S.D., J.M. Gerstein, R.R. Harris. (2007). Rural Roads: A Construction and Maintenance Guide for California Landowners." University of California Division of Agriculture and Natural Resources. Publication 8262.

Lacey, J. R., R. Wallander, and K. Olson-Rutz. (1992). Recovery, germinability, and viability of leafy spurge (Euphorbia esula) seeds ingested by sheep and goats. Weed Technology. 6:599-602.

Leonard, S., G. Kinch, V. Elsbernd, M. Borman, S. Swanson. (1997). Riparian area management: Grazing management for riparian-wetland areas. Technical Reference 1737-14. U.S. Department of Interior, Bureau of Land Management, National Applied Resource Sciences Center, Denver, CO. p. 63.

Loredo, I., D. Van Vuren, and M.L. Morrison. (1996). Habitat use and migration behavior of the California tiger salamander. Journal of Herpetology 30: 282-285.

Luginbuhl, J. M., J. T. Green, Jr., M. H. Poore, and A. P. Conrad. (2000). Use of goats to manage vegetation in cattle pastures in the Appalachain region of North Carolina. Sheep and Goat Research Journal. V. 16, No. 3, p. 124-130.

Macon, D. (2002). Grazing for Change: Range and Watershed Management Success Stories in California. California Cattlemen's Association, Sacramento, CA.

Masters, R.A. and R.L. Shelley. (2001). Invited Syntheis Paper: Principles and Practices for Managing Rangeland Invasive Plants. Journal of Range Management 54: September 2001 p 502-517.

McDougald, N. K., W. J. Clawson, J. W. Bartolome, and W. E. Frost. (1991). Estimating livestock grazing capacity on California annual rangeland. U.C. Davis Range Science Report 29.

Minnesota Department of Agriculture. Conservation Practices: Gully and Grade Stabilization. Website Accessed May 25, 2011. http://www.mda.state.mn.us/protecting/conservation/practices/gradestab.aspx

Natural Resource Conservation Service. (2005). Mulches and Mulching for Erosion Control. Technical Notes, Plant Materials 8.1 and 8.2. United States Department of Agriculture. 


\section{APPENDIX I Goals, Objectives, Actions and Descriptions}

Natural Resource Conservation Service. (2007). Grade Stabilization Techniques. Technical Supplement 14G. United States Department of Agriculture.

NRCS National Handbook of Conservation Practices; NRCS Planning and Design Manual, NRCS.

Paine, L. K., D. Undersander, and M. D. Casler. (1999). Pasture growth, production, and quality under rotational and continuous grazing management. Journal of Productive. Agriculture. V. 12, p. 569-577

Petranka, J.W. (1998). Salamanders of the United States and Canada. Smithsonian Institution Press, Washington, D. C. xvi +587 pp.

Pittroff, W. (2001). Grazing weeds and toxins: A viable control alternative? Noxious Times. Winter. p. 4-5.

Pyke, D., M. Brooks, C.M. D’Antonio. (2002). Fire as a restoration tool: a life form decision framework for predicting the control or enhancement of plants using fire. Restoration Ecology.

Rein, F.A., M. Los Huertos, R.C. Curry, and M. Fitzsimmons. (1998). Effects of Perennial Grass Buffer Strips on Movement of NPS Pollution from Cropland to Wetland. UC Water Resources Center Technical Completion Report W-866, UC Berkley.

Ross, M.A. and C.A. Lembi. (1999). Applied weed science. Prentice Hall, Upper Saddle River, N.J.

Shaffer, H. B., D. Cook, B. Fitzpatrick, K. Leyse, A. Picco and P. Trenham. 2008. Guidelines for the relocation of California Tiger Salamanders (Ambystoma californiense). Final Report, U.S. Fish and Wildlife Service.

Shaffer, H.B., R.N. Fisher, and S.E. Stanley. 1993. Status report: the California tiger salamander (Ambystoma californiense). Final report for the California Department of Fish and Game. 36 pp.

Society for Ecological Restoration International. (2004). SER Primer. http://www.ser.org/content/ecological restoration primer.asp\#3

Standiford, R. B., J. W. Bartolome, W. E. Frost, and N. K. McDougald. 1999. Using GIS in agricultural land assessment for property taxes. Geographic Information Sciences 5(1):47-51.

Stebbins, R.C. 2003. A Field Guide to Western Reptiles and Amphibians. Third edition Houghton Mifflin Company, Boston, MA. 533 pp.

Stebbins, R.C. 1989. Declaration of R. C. Stebbins in support of petition of writ of mandate. Sierra Club and Richard Pontuis v. Gilroy City Council, Shappell Industries et al. Santa Clara County Superior Court. March 16, 1989. 11 pp.+exhibits. 


\section{APPENDIX I Goals, Objectives, Actions and Descriptions}

Stuth, J.W. (1991). Foraging Behavior in R.K. Heitschmidt and J.W. Stuth (eds) Grazing Management: An Ecological Perspective. Timber Press, Portland Oregon

Sullivan, P. (2003). Conservation Tillage. Appropriate Technology Transfer for Rural Areas. National Center for Appropriate Technology.

Tatarian, Greg. Design, Installation, and Monitoring of Successful Bathouses. Wildlife Research Associates. http://www.wildliferesearchassoc.com/Napa RCD Bat house article.pdf.

University of California Davis. (2011). California Rangelands: Improving Range Forage Production. Website:

http://californiarangeland.ucdavis.edu/range_profession/improving_range.htm.

U.S. Fish and Wildlife Service (USFWS). 2004b. Endangered and threatened wildlife and plants; determination of threatened status for the California tiger salamander; and special rule exemption for existing routine ranching activities; final rule. Federal Register 69:4721147248.

U.S. Fish and Wildlife Service (USFWS). 2002. Recovery Plan for the California Red- Legged Frog (Rana aurora draytonii). Portland, OR. vii + $173 \mathrm{pp}$.

Valentine, J.R. (1989). Range Development and Improvements. Academic Press, Inc. 524 pp.

Welch, T.G., B.S. Rector and J.S. Alderson. Seeding Rangeland. Texas Water Resources Institute. (2011). http://pecosbasin.tamu.edu/bmp-information

Whisenant, Steve. (1997). An Overview of Brush Sculpting Principles. Brush Scuplters Innovations for Tailoring Brushy Rangelands to Enhance Wildlife Habitat and Recreational Value. TAMU Agricultural Research \& Extension Center. Proceedings of a Conference. http://texnat.tamu.edu/library/symposia/brush-sculptors-innovations-fortailoring-brushy-rangelands-to-enhance-wildlife-habitat-and-recreationalvalue/\#foreword 
APPENDIX J Best Management Practices and their Effect on the Landscape

\begin{tabular}{|c|c|c|c|c|c|c|c|c|c|c|c|c|c|c|c|c|c|c|c|c|c|c|}
\hline \multirow{2}{*}{ Management Practice } & \multicolumn{3}{|c|}{ Wetland } & \multicolumn{2}{|c|}{ Ponds } & \multicolumn{3}{|c|}{ Instream } & \multicolumn{4}{|c|}{ Riparian } & \multicolumn{7}{|c|}{ Rangeland } & \multirow{2}{*}{$\begin{array}{l}\text { Oak } \\
\text { HAB }\end{array}$} & \multicolumn{2}{|c|}{ Livestock } \\
\hline & ERO & HAB & WQ & HAB & WQ & ERO & HAB & WQ & ERO & HAB & RES & WQ & ERO & HAB & $\mathrm{PR} / \mathrm{U}$ & SOI & FIRE & DRO & NOX & & PRO & HEA \\
\hline \multicolumn{23}{|l|}{ Structural Range Improvements } \\
\hline Exclusionary Fencing & $x$ & & $x$ & & $x$ & $X$ & $X$ & $X$ & $x$ & $x$ & $x$ & $x$ & $X$ & $X$ & & $X$ & & $x$ & & $X$ & & \\
\hline $\begin{array}{l}\text { install fences to enclose "special use" } \\
\text { riparian paddocks, which should be small } \\
\text { and allow for careful management, } \\
\text { particularly in riparian areas. }\end{array}$ & & & & & & & & & & & & & & $x$ & $x$ & & $x$ & & & & & \\
\hline Access Roads & $x$ & & $x$ & $x$ & $x$ & $x$ & & $x$ & $x$ & & & $x$ & $x$ & & & $x$ & & & & & & \\
\hline Pipelines (water diversion) & & & $x$ & & $x$ & & & $x$ & & & & $x$ & & & & & & & & & & \\
\hline Stock Ponds & $x$ & $x$ & $x$ & & & $x$ & $x$ & $x$ & $x$ & $x$ & $x$ & $x$ & & $x$ & & & & & & & & $x$ \\
\hline Troughs and Tanks & $x$ & $x$ & $x$ & $x$ & & $x$ & $x$ & $x$ & $x$ & $x$ & $x$ & $x$ & & $x$ & & & & & & & & $x$ \\
\hline Spring Development & $x$ & $x$ & $x$ & $x$ & & $x$ & $x$ & $x$ & $x$ & $x$ & $x$ & $x$ & & $x$ & & & & & & & & $x$ \\
\hline Well Development & $x$ & $x$ & $x$ & $x$ & & $x$ & $x$ & $x$ & $x$ & $x$ & $x$ & $x$ & & & & & & & & & & \\
\hline Stream Crossings (culverts, bridges, & & & & & & $x$ & & $x$ & $x$ & & & $x$ & & & & & & & & & & \\
\hline Sediment Basins & $x$ & & $x$ & & $x$ & $x$ & & $x$ & $x$ & & $x$ & $x$ & $x$ & & & & & & & & & \\
\hline Streambank repair and protection & & & & & & $x$ & $x$ & $x$ & $x$ & $x$ & $x$ & $x$ & & & & & & & & & & \\
\hline $\begin{array}{l}\text { place sharp stones in any water crossing } \\
\text { areas to discourage lounging in streams }\end{array}$ & & & & & & $x$ & & $x$ & $x$ & & & $x$ & & & & & & & & & & \\
\hline \multicolumn{23}{|l|}{ Livestock Management Practices } \\
\hline Provide off-site attractants & $x$ & $X$ & $x$ & $x$ & $x$ & $x$ & $x$ & $x$ & $x$ & $x$ & $x$ & $x$ & $x$ & $x$ & & & & & & & $x$ & $x$ \\
\hline $\begin{array}{l}\text { Adjust Grazing Frequency (prescribed } \\
\text { grazing) (rotational grazing) }\end{array}$ & $x$ & $x$ & $x$ & $x$ & $x$ & $x$ & $x$ & $x$ & $x$ & $x$ & $x$ & $x$ & $x$ & $x$ & $x$ & $x$ & & $x$ & $x$ & $x$ & $x$ & $x$ \\
\hline Adjust Stock Density (prescribed grazing) & $x$ & $x$ & $x$ & $x$ & $x$ & $x$ & $x$ & $x$ & $x$ & $x$ & $x$ & $x$ & $x$ & & $x$ & $x$ & & $x$ & $x$ & $x$ & $x$ & $x$ \\
\hline $\begin{array}{l}\text { Adjust Herd Distribution (prescribed } \\
\text { grazing) }\end{array}$ & $x$ & $x$ & $X$ & $x$ & $x$ & $x$ & $x$ & $x$ & $x$ & $x$ & $x$ & $x$ & $x$ & $x$ & $x$ & $x$ & & $x$ & $x$ & $x$ & $x$ & $x$ \\
\hline $\begin{array}{l}\text { Adjust rangeland rest between grazing } \\
\text { periods (prescribed grazing) }\end{array}$ & & & & & & & & & & & & & $x$ & $x$ & $x$ & $x$ & & $x$ & $x$ & & & \\
\hline $\begin{array}{l}\text { Seasonal riparian grazing (timing) } \\
\text { (prescribed grazing) i.e. the fall when } \\
\text { instream water is low }\end{array}$ & & & & & & $x$ & $x$ & $x$ & $x$ & $x$ & $x$ & $x$ & & $x$ & & & & & & & & \\
\hline $\begin{array}{l}\text { Cattle selection (selecting types of cattle } \\
\text { that are known to have particular and } \\
\text { desirable rangeland behavior } \\
\text { characteristics) }\end{array}$ & & & & & & $x$ & $x$ & $x$ & $x$ & $x$ & $x$ & $x$ & $x$ & & $x$ & $x$ & & $x$ & & & $x$ & $x$ \\
\hline $\begin{array}{l}\text { Culling herd based on annual weather } \\
\text { conditions }\end{array}$ & $x$ & $x$ & $x$ & $x$ & $x$ & $x$ & $x$ & $x$ & $x$ & $x$ & $x$ & $x$ & $x$ & & $x$ & $x$ & & $x$ & & & $x$ & $x$ \\
\hline $\begin{array}{l}\text { pasture selection based on soil conditions } \\
\text { (cattle not allowed to graze in areas with } \\
\text { wet soils or highly erodible land) }\end{array}$ & & & & & & & & & & & & & $x$ & $x$ & $x$ & $x$ & & $x$ & $x$ & & & \\
\hline Never irrigate and graze at the same time. & & & & & & & & & & & & $x$ & $x$ & & $x$ & $x$ & & $x$ & & & & \\
\hline Livestock Parasite Control & & & & & & & & & & & & & & & & & & & & & $x$ & $x$ \\
\hline $\begin{array}{l}\text { provide livestock with designated stream } \\
\text { crossing areas }\end{array}$ & & & & & & $x$ & $x$ & $x$ & $x$ & $x$ & & $x$ & & $x$ & & & & & & & & \\
\hline "shademobile" & & & & & & & & & & & & & $x$ & & $x$ & $x$ & & & & $x$ & & $x$ \\
\hline
\end{tabular}




\section{APPENDIX J Best Management Practices and their Effect on the Landscape}

\begin{tabular}{|c|c|c|c|c|c|c|c|c|c|c|c|c|c|c|c|c|c|c|c|c|c|c|}
\hline \multirow[b]{2}{*}{ Management Practice } & \multicolumn{3}{|c|}{ Wetland } & \multicolumn{2}{|c|}{ Ponds } & \multicolumn{3}{|c|}{ Instream } & \multicolumn{4}{|c|}{ Riparian } & \multicolumn{7}{|c|}{ Rangeland } & \multirow{2}{*}{$\begin{array}{l}\text { Oak } \\
\text { HAB }\end{array}$} & \multicolumn{2}{|c|}{ Livestock } \\
\hline & ERO & HAB & WQ & HAB & WQ & ERO & HAB & WQ & ERO & HAB & RES & WQ & ERO & HAB & $\mathrm{PR} / \mathrm{U}$ & SOl & FIRE & DRO & NOX & & PRO & HEA \\
\hline \multicolumn{23}{|l|}{ Land Treatments } \\
\hline $\begin{array}{l}\text { Range seeding (native-drought tolerant } \\
\text { grasses) }\end{array}$ & & & & & & & & & & & & & $\mathrm{x}$ & & $x$ & $\mathrm{x}$ & & $\mathrm{x}$ & $x$ & & & \\
\hline Grade stabilization & & & & & & & & & $x$ & & $x$ & $x$ & $x$ & & & & & & & & & \\
\hline Mulching & & & & & & & & & $\mathrm{x}$ & & $\mathrm{x}$ & $\mathrm{x}$ & $\mathrm{x}$ & & $\mathrm{x}$ & $\mathrm{x}$ & & $\mathrm{x}$ & $\mathrm{x}$ & & & \\
\hline Brush Management & & & & & & & & & & & & & & $\mathrm{x}$ & $x$ & $x$ & $x$ & $\mathrm{x}$ & $\mathrm{x}$ & $\mathrm{x}$ & $\mathrm{x}$ & $x$ \\
\hline Native shrub and tree planting & $x$ & $\mathrm{x}$ & $x$ & $\mathrm{x}$ & $\mathrm{x}$ & $x$ & $\mathrm{x}$ & $x$ & $x$ & $\mathrm{x}$ & $x$ & $x$ & $\mathrm{x}$ & $\mathrm{x}$ & $x$ & $x$ & & $\mathrm{x}$ & $x$ & & $\mathrm{x}$ & $x$ \\
\hline $\begin{array}{l}\text { Pasture forage regrowth (pature rested } \\
\text { and provided sufficient time for forage to } \\
\text { regrow leaf area and build up stored } \\
\text { reserves in their roots }\end{array}$ & & & & & & & & & & & & & $x$ & $x$ & $x$ & $x$ & & $x$ & $x$ & $x$ & $\mathrm{x}$ & $x$ \\
\hline $\begin{array}{l}\text { Prohibit cattle from grazing seed } \\
\text { producing plants while they are setting } \\
\text { seed }\end{array}$ & $x$ & $x$ & $x$ & & & & & & & & & & $x$ & & $x$ & $x$ & & $x$ & $x$ & & & \\
\hline $\begin{array}{l}\text { Prohibit cattle from grazing when } \\
\text { enviromental conditions such as cold } \\
\text { weather or drought restrict plant growth } \\
\text { (riparian) }\end{array}$ & $x$ & $x$ & $x$ & & & & & & $x$ & $x$ & $x$ & $x$ & $x$ & & $x$ & & & & & & & \\
\hline $\begin{array}{l}\text { Disallow grazing while soil is } \\
\text { wet/saturated }\end{array}$ & $x$ & $x$ & $x$ & & & & & & $x$ & & & $x$ & $x$ & & $x$ & $x$ & & $x$ & & & & \\
\hline $\begin{array}{l}\text { Prohibit cattle from grazing compacted } \\
\text { areas during or after the wet season }\end{array}$ & $x$ & $x$ & $x$ & & & $x$ & $x$ & $x$ & $x$ & $x$ & $x$ & & & & & & & & & & & \\
\hline $\begin{array}{l}\text { Prohibit cattle from grazing riparian areas } \\
\text { when banks are sloughing or breaking } \\
\text { down }\end{array}$ & & & & & & & & & $x$ & $x$ & $x$ & $x$ & & & & & & & & & & \\
\hline $\begin{array}{l}\text { Minimize prolonged grazing or } \\
\text { congregation around water, under shade } \\
\text { or in other favored areas }\end{array}$ & $x$ & $x$ & $x$ & $x$ & $x$ & $x$ & $x$ & $x$ & $x$ & $x$ & $x$ & $x$ & & & & & & & & $x$ & & \\
\hline $\begin{array}{l}\text { Incorporate snags, logs, and other large } \\
\text { woody debris into management plan }\end{array}$ & & $x$ & & $x$ & & & $x$ & & & $x$ & & & & $x$ & & & & & & & & \\
\hline Residual Dry Matter Management & & & & & & $x$ & & $x$ & $x$ & & & & $x$ & & $x$ & $x$ & & $\mathrm{x}$ & & & & \\
\hline $\begin{array}{l}\text { Control noxious weed growth in upland } \\
\text { pastures to minimize movement of seeds } \\
\text { and vegetative propagules using } \\
\text { prescribed fire, prescribed grazing or } \\
\text { manual removal depending on the } \\
\text { targeted species reproductive and } \\
\text { regeneration behavior }\end{array}$ & & & & & & & & & & $\mathrm{x}$ & & & & & $x$ & & & $x$ & $x$ & & & \\
\hline \multicolumn{23}{|l|}{$\begin{array}{l}\text { Facility Siting/Design Criteria } \\
\text { Irrigated Row Crops and Orchards }\end{array}$} \\
\hline $\begin{array}{l}\text { Appropriately constructed and placed bird } \\
\text { and bat boxes }\end{array}$ & & $x$ & & $x$ & & & $x$ & & & $x$ & & & & $x$ & & & & & & & & \\
\hline $\begin{array}{l}\text { Bird water ramps in water troughs and } \\
\text { developed springs (grazing for change 2) }\end{array}$ & & $x$ & & $x$ & & & $x$ & & & $x$ & & & & $x$ & & & & & & & & \\
\hline \multicolumn{23}{|l|}{ Solar powered water distribution } \\
\hline $\begin{array}{l}\text { Training livestock to eat nutritious weeds } \\
\text { (prescribed grazing) }\end{array}$ & & & & & & & & & & & & & & & $x$ & & $x$ & & $x$ & & $x$ & $x$ \\
\hline \multicolumn{23}{|l|}{ Ground level water troughs for wildlife } \\
\hline $\begin{array}{l}\text { Remove debris build up and log jams in } \\
\text { streams }\end{array}$ & & & & & & $x$ & $x$ & $x$ & & & & & & & & & & & & & & \\
\hline $\begin{array}{l}\text { Placement of buildings, corrals, feeding } \\
\text { i.e. on ridges and away from riparian } \\
\text { areas. }\end{array}$ & & & & & & & & & $x$ & $\mathrm{x}$ & & $x$ & $x$ & & & & & & & & & \\
\hline
\end{tabular}

\begin{tabular}{|l|l|}
\hline \multicolumn{2}{|c|}{ KEY } \\
\hline Management Feature & Code \\
\hline Erosion & ERO \\
\hline Habitat & HAB \\
\hline Water Quality & WQ \\
\hline Restoration & RES \\
\hline Forage production/utilization & PR/U \\
\hline Soil Improvements & SOI \\
\hline Fire Protection/Fuel Management & FIRE \\
\hline Drought Management & DRO \\
\hline Noxious Weed Control & NOX \\
\hline Productivity & PRO \\
\hline Health & HEA \\
\hline
\end{tabular}




\section{APPENDIX K Interview Consent Form}

INFORMED CONSENT TO PARTICIPATE IN “Understanding Landowner Values in Order to Formulate Strategies for Conservation on Private Rangeland"

Master's thesis research on landowner value is being conducted by Justin T. Saydell, a graduate student in the Department of City and Regional Planning at Cal Poly, San Luis Obispo, under the direct supervision of Professor Chris Clark. The purpose of the project is to understand landowner values, long-term goals and challenges they face in the Upper Salinas Watershed in order to understand the potential for the development of conservation strategies that are beneficial to the landowner.

You are being asked to take part in this project by participating in an in-depth interview in order to understand and to capture your story (values, long-term goals and challenges that you currently face or will face in the future in order to meet your goals.) Your participation will contribute to the understanding of goals and challenges ranchers' face, which are largely misunderstood by the public and the conservation community. While mutual goals have been identified by groups such as the California Rangeland Conservation Coalition, every landowner/rancher faces different challenges and has different thoughts and feelings about longterm goals for their property and to what degree stewardship plays a role on their property. Post interview analysis will be used to determine how landowners view conservation and develop strategies for how conservation might work to benefit individual landowners. The in-depth interview process will last approximately 30 to 90 minutes and you will be asked some questions about your property, long-term goals for your property, and challenges that you currently or will face in the future in meeting your long-term goals. You are encouraged to answer the questions in a manner that is comfortable to you. The interview will be audio recorded and the interviewer will be taking notes during the interview.

Please be aware that you are not required to participate in this research and you may discontinue your participation at any time without penalty. You may also choose not to answer any questions that you would prefer not to answer.

Any information you provide regarding your operation, feelings towards conservation, or other ranchers, etc., that is later read by other ranchers, academics, public officials, etc., could potentially result in adverse effects including social and psychological issues, and tension between you and others who may view the information you provided as harmful to their property. If you should experience any of the negative outcomes mentioned above, please be aware that you may contact Justin T. Saydell, Principle Investigator/Interviewer, City and Regional Planning Dept. Cal Poly, San Luis Obispo at 440-552-9443 or Bob Hill, Executive Director The Land Conservancy of San Luis Obispo County, 547 Marsh Street, San Luis Obispo at (805) 544-9096 for assistance.

If you decide to participate in this research, your confidentiality will be protected in three ways: first you are given the flexibility to decide the degree of privacy and confidentiality you would feel comfortable with. Please circle the confidentiality option (below) that you feel the most comfortable with: 


\section{APPENDIX K Interview Consent Form}

a) Strict Confidentiality (You will NOT be identified along with the information you share. Only the Interviewer/Principle Investigator will know your identity.)

b) Medium Confidentiality (You WILL NOT be identified along with the information you share in the written and publically submitted report of the Masters Project, but your information will be included in an appendix submitted to The Land Conservancy of San Luis Obispo.)

c) Not Confidential. Information you share can be viewed by the Principle Investigator, The Land Conservancy of San Luis Obispo County AND the general public in the submitted Masters Project document.

Second, there will be a project appendix that will be considered confidential. If you provide your permission (by choosing "Medium Confidentiality, Level Two"), maps and any additional information specifically identifying you will be included in the appendix. Since the Land Conservancy of San Luis Obispo is the client for this project, the appendix will only be shared with the Land Conservancy and no one else. This appendix will not be submitted with the rest of the project for public record to fulfill the master thesis requirement.

Third, the interview may be audio recorded and transcribed. Raw information will be destroyed upon completion of the analysis and will be viewed/used only by the Principle Investigator/Interviewer.

Lastly, you will have the opportunity to change to what extent you are represented in the final product throughout the duration of the project. Final information given by you and analysis of that information will be shared with you in order to ensure transparency and to make any final edits to address your comfort with the level of confidentiality and privacy.

The exception to this confidentiality agreement is if you make statements construed as harmful to yourself or others. In this case, the proper authorities will be notified. Potential benefits associated with the project include documentation of ranchers' and large parcel landowners' individual long-term goals, values and challenges they face pursuing an agricultural/ranching lifestyle. Rancher values go largely without notice in the conservation community and in the public eye in general. Capturing your stories will contribute to a better understanding of a largely misunderstood rural lifestyle that is considered an American tradition. Another potential benefit is that your participation will give conservation groups a better understanding of the needs and challenges of landowners in rural communities. If landowners choose to work with these groups, a better understanding of landowners can lead to a greater benefit for the landowner.

If you have questions regarding this study or would like to be informed of the results when the study is completed, please feel free to contact Justin Saydell at 440-552-9443 and/or Chris Clark, faculty advisor at 805-756-6605. If you have concerns regarding the manner in which the study is conducted, you may contact Dr. Steve Davis, Chair of the Cal Poly Human Subjects 


\section{APPENDIX K Interview Consent Form}

Committee, at 756-2754, sdavis@ calpoly.edu, or Dr. Susan Opava, Dean of Research and Graduate Programs, at 756-1508, sopava@ calpoly.edu.

If you agree to voluntarily participate in this project as described, please indicate your agreement by signing below Please keep one copy of this form for your reference, and thank you for your participation in this project.

Signature of Subject

Signature of Researcher
Date

Date 


\title{
APPENDIX L Interview Questions
}

\author{
Interview Questions
}

1.) How would you describe your relationship with your land? What types of uses do you manage your land for? How long have you owned/worked on it? What would you consider to be the defining/best characteristics of your land

2.) How do you see other people perceiving the ranching community? What would you want them to know about what you do?

3.) Why is your land important to you?

4.) What are your long-term goals for your land? What do you see happening on the land in the future?

5.) What are some of the challenges that you currently face and anticipate that you may face in order to meet those goals?

6.) What are your views on conservation/stewardship? How do you currently practice conservation on your land? In what ways do you think conservation might be able to help you meet your long-term goals, if at all?

7.) What are your thoughts on organizations such as land trusts? Do you see a difference in the Land Conservancy of San Luis Obispo vs. other organizations such as the Nature Conservancy or the California Rangeland Trust?

8.) If at some point in time you would want to work with one of the groups mentioned, what are the essential components of any collaborative agreement in order for it to be a "good" agreement to you? What sort of components would definitely NOT work for you?

9.) What communication networks do you use to learn about what is going on in the ranching community, improving management practices, regulations, etc.? Do external services and information influence how you manage your land in any way? 